\title{
Kernos
}

Revue internationale et pluridisciplinaire de religion grecque antique

20 | 2007

Varia

\section{Epigraphic Bulletin for Greek Religion 2004 (EBGR 2004)}

Angelos Chaniotis and Joannis Mylonopoulos

\section{(2) OpenEdition}

\section{Journals}

Electronic version

URL: https://journals.openedition.org/kernos/201

DOI: 10.4000/kernos.201

ISSN: 2034-7871

\section{Publisher}

Centre international d'étude de la religion grecque antique

\section{Printed version}

Date of publication: 1 January 2007

Number of pages: 229-327

ISSN: 0776-3824

\section{Electronic reference}

Angelos Chaniotis and Joannis Mylonopoulos, "Epigraphic Bulletin for Greek Religion 2004 (EBGR 2004)", Kernos [Online], 20 | 2007, Online since 24 May 2011, connection on 08 September 2022. URL: http://journals.openedition.org/kernos/201 ; DOI: https://doi.org/10.4000/kernos.201 


\section{Epigraphic Bulletin for Greek Religion 2004 (EBGR 2004)}

The 17th issue of the Epigraphic Bulletin for Greek Religion presents the great majority of the epigraphic publications of 2004 and many additions to EBGR 1999-2003. We have placed emphasis on the presentation of new corpora and editions of new texts, but we could not resist the temptation to include information contained in papyri, both magical papyri and other papyri of religious interest that might otherwise remain unnoticed (153. 205). However, we can no longer follow the discussion concerning the Derveni papyrus (see more recently F. JOURDAN, Le papyrus de Derveni. Texte présenté, traduit et annoté, Paris, 2003 [with the review in Kernos 18 (2005), p. 553-556]; G. Betegh, The Derveni Papyrus. Cosmology, Theology, and Interpretation, Cambridge, 2004; T. Kouremenos, G.M. Parasoglou, K. Tsantsanoglou, The Derveni Papyrus, Florence, 2006) or the newly edited epigrams of Poseidippos which are of great interest for Hellenistic religion (e.g., B. Acosta-Hughes - E. Kosmetatou - M. BAumbach [eds.], Labored in Papyrus Leaves. Perspectives on an Epigram Collection Attributed to Posidippus (P.Mil.Vogl. VIII 309), Washington, 2004).

In addition to many new inscriptions (esp. 1-3. 11. 26. 29. 43. 57. 118-120. 135. 138. 140. 142. 151. 156. 171-173. 176-179. 187-188. 213. 223-224. 231. 241. 247. 251. 256. 268-272. 277-280. 284-285. 288. 290. 296-297. 306-307), in this issue we summarize 14 corpora, concerning the inscriptions of Dacia (235), Apulum (218), Halasarna on Kos (141), Ikaria (189), Samos (104), Akragas and Gela (8), Elea (293), the Museum of Catania (143). France (61), south Karia (31), Sinope (87), the area of Mt. Sultan Daği in east Phrygia (128), and Perge (239).

The new texts add some information concerning the worship of gods, e.g., attesting for the first time the epiklesis Aontia (or Adontia?) for Artemis in Achaia (213), identifying a sanctuary of Achilles on Thera (248), offering what may be a very early attestation of Asklepios' cult in Thessaly (288), and providing information concerning the cult of healing heroes in Mylasa (26). But studies based on previously published material, in particular surveys of cults in Roman Asia Minor (e.g., the cults of Mes, Hosios kai Dikaios, and the Twelve Gods), also make significant contributions to the study of important religious features of this period, such as an emphasis on divine justice, the concept of a hierarchy among the immortals, and the communication between gods and men (cf., e.g., 3. 159. 166. 171. 178); we single out a new analysis of Hadrian's dedicatory epigram to Eros at Thespiai as a testimony of contemporary religious mentality (102). The new edition of an oration for Theseus in Roman Athens (84) provides insights both into the cult of the Athenian hero and into the function of epideictic orations in festivals. The cult of mortals has attracted a lot of attention in recent years. In this issue the reader will find new evidence for the cult of Agrippa in 
Thessaly (135) and the imperial cult in Kalindoia in Macedonia (251), but also summaries of studies of the ranks of 'political gods and heroes' in the Hellenistic period (35), on the cult of benefactors (265), and on the rituals of the Hellenistic ruler cult (105).

There are only a few new leges sacrae, including sacrificial regulations from Athens (256) and Kos (140), but we should also mention the new copies of the lex sacra of Antiochos I of Kommagene (57; cf. 215 and 300), a new date plausibly suggested for the famous lex sacra of the mysteries of Andania (268), and new significant contributions to the interpretation of the equally famous regulation of Selinous concerning purification rituals (69 and 74). Turning to sanctuaries, their organisation and their finances, the new texts include an exciting new find from fifth-century Olympia concerning theorodokoi in Sparta and Euboia which seems to show that the sanctuary possessed a widespread network of relations at an early stage (247), a very interesting Hellenistic decree from Halasarna forbidding the use of sacred property as surety for loans (141); and another inscription from the same city which shows that former priests constituted a board (141). We should also mention contributions to the study of temple inventories (145-149), an important source of information for dedicatory practices and the terminology used for dedications; in connection with the vocabulary of dedications, we point to a new text from Halasarna which attests the unusual designation of a dedication as an sid $\alpha \sigma \tau \dot{n} \varrho ı$ (141). We also note the publication of an excellent study of dedicatory practices in late Hellenistic and Roman Greece (244). Among the new texts we single out a dedication of an alumnus to an anonymous god in Thyraion (126).

The study of 'Dionysiac-Orphic' texts has been moved forward both through new editions of this material (20 and 222) and through important observations concerning the content of these texts (esp. $65 ;$ cf. 221). Another group of exciting texts which is continually increasing and also attracting the attention it deserves consists of the so-called 'confession inscriptions'. Although this issue presents only one new text (179; for new texts see P. HERRMANN - H. MALAY, New Documents from Lydia, Vienna, 2007 [Tituli Asiae Minoris, Ergänzungsband]), we note several studies devoted to these texts and their religious and sociological aspects (esp. 18. 44-45. 98-99. 126. 294). A new inscription from Philomelion (126) seems to condemn unjust oaths, which is also a common theme in 'confession inscriptions'. Sociological aspects of religion are illuminated not only by 'confession inscriptions', but also by studies of cult associations (9. 15), of women participation in religion (22), and of the reproduction of social patterns in cult communities (96). We also mention an interesting text (an old find) from Kyrene which demonstrates how something as innocents as the sending of a delegation to a festival could be politically explosive in the context of rivalries between cities in the Roman Empire (164).

Many new texts provide information concerning concepts of the afterlife (e.g., 114. 156) and funerary customs. We single out several interesting funerary imprecations (126. 171) as well as new evidence for the efforts of individuals to safeguard the continuation of their funerary cult (1. 124), for the heroisation of the dead (189), and for the protection of the grave (158. 187). The reader of this issue will not fail to observe the large number of studies devoted to magic in the broadest sense of the word, 
especially to curse tablets (e.g., 128-129. 131. 151. 278. 280. 282. 307) and phylacteries (e.g., 11. 80-81. 277). The identification of a particular group of curses, 'prayers for justice' (13. 44-45. 128. 278. 280), including justified curses (126. 129), has marked a significant step forward in efforts to give defixiones the place they deserve in the history of mentalities. Other stimulating developments concern the study of the circulation of magical handbooks from which spells and recipes were copied and adapted (80. 97. 130) and of syncretistic trends in magic (e.g., 81. 196. 245).

Considering the evolution of the 'epigraphic habit' in the Greek world, it is not surprising that the number of inscriptions pertaining to religion increases in the Imperial period, including areas on the periphery of Greek religion. This makes a study of the interaction between traditional Greek religion and other religious traditions and of the various forms of 'syncretism' possible. After the concept of 'Romanisation' was shown to be inadequate to describe the multifaceted impact of Roman rule in the Roman East, recent scholarship proposes more differentiated approaches to this subject (e.g., 19. 27. 78. 138. 170. 243). The complex relations between different religious groups (pagans, Jews, and Christians) can also be studied in Late Antiquity; an interesting phenomenon is the convergence of the religious vocabulary of different religious traditions, which makes the attribution of some texts (e.g., 4. 11) to a particular group difficult. As regards the conflict between Hellenic religion and Christianity in late Antiquity, a very important new find is an inscription of Ikaria (189) which contains an oracle of Apollon Pythios, also quoted by Christian authors, referring to the conversion of ancient temples into churches of Mary (5th cent. AD).

The principles explained in Kernos 4 (1991), p. 287-288 and Kernos 7 (1994), p. 287 also apply to this issue. Abbreviations which are not included in the list of abbreviations are those of L'Année Philologique and J.H.M. STRUBBE (ed.), Supplementum Epigraphicum Graecum. Consolidated Index for Volumes XXXVI-XLV (1986-1995), Amsterdam, 1999, as well as of later volumes of the SEG. If not otherwise specified, dates are BC. We are very much obliged to Benjamin Gray (All Souls College, Oxford) for improving the English text. [AC]

\author{
Abbreviations \\ Actes - Antioche de Pisidie \\ AEThSE 1 \\ Anacharsis \\ AST 19 \\ AST 20 \\ AST 21 \\ AST 22 \\ T. DREW-BEAR et al. (eds.), Actes du Ier Congrès International sur \\ Antioche de Pisidie, Lyon, 2002.

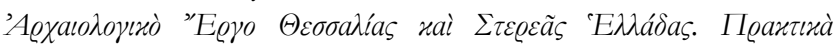

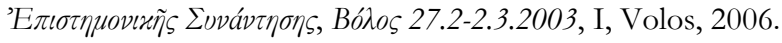

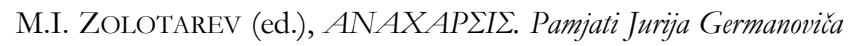 \\ Vinogradova, Sevastopol, 2001 (Khersonesskij sbornik 11). \\ 19. Arastırma Sonucları Toplantısı, Ankara 27-31 Mayis 2001, \\ Ankara, 2003. \\ 20. Araştırma Sonuçlar Toplantısı, Ankara 27-31 Mayis 2002, \\ Ankara, 2003. \\ 21. Arastırma Sonucları Toplantısı, Ankara 21-31 Mayis 2003, \\ Ankara, 2004. \\ 22. Araștırma Sonuclar Toplantısi, Konya 24-28 Mayis 2004, Ankara, \\ 2005.
}


Asyl

Attikai Epigraphai

The Cauldron of Ariantas

Les cultes locaux

L'épigramme

Epigraphica - Guarducci

Ergo-Thessalia

The Greco-Roman East

L'bellénisme d'époque romaine

The Hellenistic Polis of Kos

L'Illyrie IV

NGSL

Paramone

Religionsgeschichte Kleinasiens
M. DreHER (ed.), Das antike Asyl. Kultische Grundlagen, rechtliche Ausgestaltung und politische Funktion, Cologne et al., 2003.

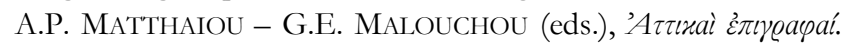

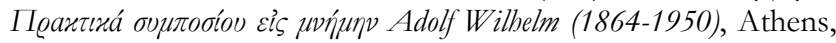
2004.

P.G. BILDE et al. (eds.), The Cauldron of Ariantas. Mélanges en l'honneur de A.N. Sčeglov, Aarhus, 2003.

G. LABARRE (ed.), Les cultes locaux dans les mondes grec et romain. Actes du colloque de Lyon 7-8 juin 2001, Lyon, 2004.

J. DiON (ed.), L'épigramme de l'Antiquité au XVIIe siècle ou Du cisean à la pointe, Nancy, 2002.

M.L. Lazzarini - G. Molisani - S. PANCiera (eds.), Epigraphica. Atti delle Giornate di Studio di Roma e di Atene in memoria di Margherita Guarducci (1902-1999), Rome, 2003.

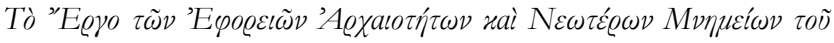

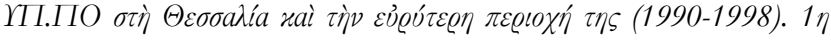

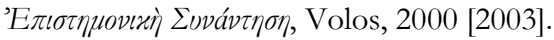

S. Colvin (ed.), The Greco-Roman East. Politics, Culture, Society, Cambridge, 2004 (Yale Classical Studies 31).

S. Follet (ed.), L'bellénisme d'époque romaine. Nouveaux documents, nouvelles approches (Ier s. a.C. - III ${ }^{e}$ s. p.C.C.). Actes du colloque international à la mémoire de Louis Robert, Paris, 7-8 juillet 2000, Paris, 2004. K. Höghammar (ed.), The Hellenistic Polis of Kos. State, Economy, and Culture, Uppsala, 2004 (Boreas 28).

P. CABANES - J.-L. LAMBOLEY (eds.), L'Illyrie méridionale et l'Épire dans l'Antiquité. IV. Actes du IV colloque international de Grenoble (10-12 octobre 2002), Paris, 2004.

E. LuPU, Greek Sacred Law. A Collection of New Documents, Leiden, 2005 (RGRW, 152).

J.M.S. Cowey - B. Kramer (eds.), Paramone. Editionen und Aufsätze von Mitgliedern des Heidelberger Institutes für Papyrologie zwischen 1982 und 2004, Leipzig, 2004.

G. HeEdemanN - E. Winter (eds.), Neue Forschungen zur Religionsgeschichte Kleinasiens. Elmar Schwertheim zum 60. Geburtstag gewidmet, Bonn, 2003 (Asia Minor Studien 49).

\section{Selected Topics $[\mathrm{AC}]$}

Geographical areas (in the sequence adopted by SEG)

Athens/Attica: 9. 15-16. 21. 24. 49. 54-55. 83-84. 117. 127. 131.137.145. 147-149. 155156. 160-163. 171bis. 174-175. 185-186. 200. 206. 209-210. 242. 256. 264. 267. 272. 286. 307; Brauron: 63. 208; Eleusis: 31; Marathon: 82; Rhamnous: 212; Sounion: 95. 240. Aigina: 83. Sikyonia: Sikyon: 144. Argolis: Argos: 38. 192. 216. Epidauria: Epidauros: 31. 101. 233. 299. Lakonia: Sparta: 76. 233. 247. 271. 295; Tainaron: 306. Kythera: 284. Messenia: Andania: 62. 268; Messene: 62. 268-270. Arkadia: Mantineia: 102. 275; Megalopolis: 35. Elis: 14. 234; Olympia: 14. 242. 247. Achaia: 213. Boiotia: 283. 298; Oropos: 110; Tanagra: 242. 305; Thebes: 6; Thespiai: 17. 102. 125. 297. Delphi: 88. 94. 149. 195. 198. 229. 238. 301. Phokis: Drymaia: 94. West Lokris: Naupaktos: 188. Thessaly: 101. 108. 135. 227; 
Gonnoi: 142; Halos: 199; Itonos: 230; Mopseion: 288; Pherai: 193. Epeiros: 37. 225; Dodone: 33. 86. 107. 255. Illyria: 37. 225; Apollonia: 226. Macedonia: 64; Dion: 107. 217; Kalindoia: 251; Leukopetra: 106; Pella: 47-48; Thessalonike: 64. Thrace: Anchialos: 139; Augusta Traiana: 257; Maroneia: 304; Pistiros/Vetren: 7. 72. Moesia: Histria: 10; Nikopolis ad Istrum: 173. 285; Oescus. 152. Dacia: 235. 243; Apulum: 218. North Shore of the Black Sea: 60. 308; Nymphaion: 252; Olbia: 121. 236. 276. 296; Panskoye: 258; Pantikapaion: 276; Porthmion: 290; Tyritake. 276. Delos: 46. 128. 146-149. 253. Rhodes: 30. 39. 261; Ialysos: 223-224; Lindos: 113. 134. Lesbos: Eresos: 182; Mytilene: 136. Kyklades: 22. 167; Amorgos: 109. 182; Anaphe: 34; Andros: 202; Keos: 88; Paros: 187; Tenos: 34; Thera. 91. 233. 248. Chios: 181. Kos: 29. 35-36. 108. 140-141. 230. Nisyros: 203. Samos: 59. 104. 204. Koressia: 104. Ikaria: 104. 189. Samothrake: 230. Euboia: 46. 247; Eretria: 182. Crete: 23. 92; Inatos: 204; Kommos: 58; Lebena: 250; Phaistos: 221. Sicily: Akragas: 8. 219; Gela: 8. 211. 219; Katane: 143; Selinous: 31. 69. 74. 151. Italy: 129; Elea: 289. 293; Ostia: 165. Gaul: 61. Britannia: 277-280. Asia Minor: 4. 27. 40. 44. 67. 112. Karia: 11. 31. 77. 234bis; Alabanda: 25. 34; Aphrodisias: 43; Keramos: 292; Knidos: 44; Mylasa: 25-26; Stratonikeia: 291; Tralleis: 33. 71. Ionia: Ephesos: 273; Magnesia on the Maeander: 34. 108; Metropolis: 73bis; Miletos: 147; Smyrna: 34. 158; Teos: 34. Lydia: 44. 98-99. 111. 178-179; Kollyda: 177; Philadelpheia: 214. Aiolis: 115; Kyme: 35. Troas: Ilion: 103. Mysia: Gambreion: 88; Pergamon: 97. 105. 122-125. 183. Bithynia: 218; Bithynion: 102. Pontos: Sinope: 87. Galatia: Ankyra: 157; Tavium: 263. Phrygia: 3. 11. 44. 53. 98-99. 126. 171. 197; Aizanoi: 168; Hierapolis: 190. 231; Pessinous: 228; Philomelion: 176. Pisidia: 116. 138; Antiocheia: 159. 166. Pamphylia: 118. 170; Perge: 239. Lykia: 73. 119. 169. 241; Kibyra: 50-52. 116; Limyra: 303; Olympos: 2; Termessos: 120; Tlos: 1; Trebenna: 124. Kilikia: 78. 259; Aigeai: 259; Anazarbos: 53. 309; Anemourion: 259; Diokaisareia: 259; Elaioussa Sebaste: 28. Cyprus: 194; Kafizin: 180; Kourion: 102; Paphos: 42. Kommagene: 215. 300; Zeugma: 57. Syria/Palaestina: 19. 191; Askalon: 89; Sidon: 266. Egypt: 12. 68. 70. 154. 245. Kyrene: 164.

acclamation: 96.235 .239 .302

afterlife: 38. 61. 65. 87.91.104. 114.124. 156. 189. 286

agon: 26 ; cf. s.v. festival

altar: 1. 3. 5. 11. 26. 28. 48. 87. 126. 214. 234bis. 235. 292-293; funerary altar: 1. 29. 189

amphictyony: 94. 195. 234. 238

amulet: 4. 11. 61. 80. 184. 276.279; cf. s.v. gem, magic, phylactery

anatomical votive: 101.104

animal, sacrificial: 1. 140; bull: 141. 225; cow: 26; donkey: 12; eagle: 44; ewe: 140; goat: 140; ram: 172; sheep: 140; snake: 26. 249; cf. Greek words

apotropaic text/object: 61.295

archaism: 244

aretalogy: 246

Asiarches: 40-41. 220

association, cult: 1. 9. 15. 17. 31. 120. 235. 243. 272. 289. 293. 297; cf. Greek words

astrology: 87.143

asylia: 34. 36. 52. 108. 231. 239. 275

banquet: 39. 87. 105. 109. 182. 189

bell: 123.295 
benefactors, cult of: 5.35 .265

birthday, of deity: 83

boundary stone, of burial place: 29; of sacred property: 293; of sanctuary: 17. 141. 293

burial: 75.187 ; sealing of grave: 239 ; $c$. s. $v$. funeral, funerary cult

calendar: 31 (Rhodian in Karia). 37 (Korinthian in colonies). 87 (Sinope). 203 (Nisyros). 240

(cult calendar?); cf. s.v. sacrificial calendar

cave: 144.289

Christianity: 11. 116. 126; pagan influence on: 87. 184. 189; Christian influence: 165

communication, between humans and gods: 18. 204; intermediaries between mortals and gods: 102

competition among cities: 52.164

confession inscription: 18. 27. 44-45. 98-99. 126. 179. 294

crown, of priest: 87.147 ; of theoroi: 230 ; crowning: 31.105

cult, assimilation of: 27 ; augmentation of: 31 ; family cult: 32 ; foundation of c. by individual: 21. 177; funding of: 24; introduction of: 21. 31. 73bis. 169-170. 176. 218. 273. 309; participation in: 140; reform: 62; regulation: 26; reorganisation: 24; transfer: 19. 109. 243

cult of mortals, in the Hellenistic period: 35. 265; of benefactors: 5. 35. 265; of Romans: 5. 135 (Agrippa). 234bis (C. Marcius Censorinus); Antinoos: 102; cf. s.v. emperor cult, heroisation, ruler cult

cult officials: agonothetes: 87. 105. 143. 160.170. 216. 239. 252. 259. 270. 301; aniptopous: 33; epimeletes: 9; hiera: 53. 104; hierophantes: 62; hierophylax: 230; hieropoios: 9. 141. 162. 206. 272; hieros: 104. 168. 268; hierotamias: 32; hierothytes: 39; karneiastes: 268; klakophoros: 226; kleidophoros: 226; kosmetes: 272; kosmetor: 137; mastigophoros: 239; neokoros: 31; neopoies/napoies: 104. 140-141; oinotamias: 31; pallake/pallakis: 33; panegyriarches: 87. 104; prophetes: 61; theophoros: 104; cf. s.v. priests; Greek words cult officials, hereditary: 33.62 .141 .239 ; iteration in office: 33

curse: 4. 26. 126; justification of c: 126. 129; curse tablet: 13. 44. 47. 54-55. 61. 127-132. 151. 219. 235. 278. 280. 282. 294. 307

death: 38.61

dedication: 92. 101. 113. 145-148. 244; cf. Greek words

dedication, dedicants: artisan: 49. 180. 266. 298; cult association: 235; friends (hetairoi): 118 119; magistrate: 29. 87. 104. 200 (after the term in office: 181. 209. 239. 270); priest/ cult official: 26. 43. 100. 141. 252 (after the term in office: 31. 33. 141. 269); professional association: 141. 218; royalty: 145 ; sailor: 28 ; slave: 43. 61; soldier: 235 . 257. 299; village: 3.171 ; woman: 22

dedication, object of: bell: 295; mirror: 213; person (slave: 106; threptos: 126); writing tabet: 204; cf. s.v. anatomical votive

dedication, motivation: divine command: 73; dream: 48. 71. 298; oracle: 31. 33. 61; safe journey: 121; spontaneous: 126 , thanks-giving d.: 31; victory in war: 242.298

dedication for, emperor: 31. 104. 126. 141. 191. 269; family member: 3. 22. 26. 166. 191. 234bis; magistrate: 31 ; the paides: 29

defixio: see curse tablet

deities: Aglauros: 16. Amphitrite: 22. Anteros: 5. Aphrodite: 31. 42-43. 61. 89. 100. 102. 104. 140. 176. 194. 227. 240. 244. 270. 309; Euploia 181; Ourania 102. 276; Paphia 85; 
Stratonikis 34; Synarchis 104. Apollon: 3. 5. 37. 57. 58-59. 61. 72. 81. 89. 104. 140-143. 155. 170-171. 208. 227. 229. 240. 244. 253. 296. 298. 300; Agreus 142. 227; Aiginaios 296; Aisonios 142. 227; Aktios 142; Apotropaios 61; Boreus 236. 296; Chresmodotes 11; Delios 46. 72. 185-186; Delphinios 155. 207. 236; Doreios 227; Embasios 142; Epekoos 57; Hypoakraios 200; Ietros 236. 296; Karneios 167. 268; Karsenos 139; Kerdoos 227; Kitharodos 139; Lykeios 207. 227. 236; Maleatas 207. 233; Oulios 293; Panlimnios 142. 227; Patro(i)os 16. 273; Pholeuterios 289; Platytoxos 298; Pleurenos 111; Prieleus 104; Ptoios 298; Pythios 61. 104. 142. 155. 227. 301; Sozon 126; Syidenos 257; T(b)argelios 236. Archegetes: 256. Ares: 53. 73 bis. 118-119. 244. Aristaios: 61. Artemis: 22. 37. 59. 61. 72. 95. 115-116. 169. 183. 202. 218. 226. 239-241. 244. 253; Adrastea 226; Agagylaia 227; Agrotera 140. 226; Alpheia 234; Aontia 213?; Aristoboule 207; Boulaia 200. 207; Diktynna 57; Eileithyia 226-227; Ephesie 276; Euomymos 227; Ephesia 239; Geneteira 227; Heleia 227; Kekoia 30; Kitaneurissa 2; Kombike 1; Kynegetis 241; Leukophryene 108. 183. 227; Limnatis 226; Lochia 227; Oupesia 62; Paidotrophos 226; Parthenos 227; Pergaia 170; Pergesia 239; Phosphoros 61. 226-227; Proskopa 226; Pytheis 140; Pythochrestos 207; Soteira 226; Tauropolos 104. 189. Asklepios: 5. 15. 21 22. 64. 89. 101. 105. 123-125. 167. 212. 217-218. 227. 230. 235. 240. 244. 250. 284. 288; Pergamenos 243; Soter 87. 95. 217. Athena: 22. 37. 58-59. 83. 89. 167. 170. 218. 223-224. 227. 234. 240. 244; Agelaa 16; Alseia 29; Chalkioikos 295; Ergane 49; Hellenie 293; Hoplophoros 227; Hygieia: 49; Ithydikos 138; Itonia 108. 230; Kamiras 39; Lindia 30. 113. 134; Nike 49; Patroa 227; Polias 39. 87. 140. 145. 188. 227. 293; Skiras 16; Soteira 87. 140; Sounias 95. 240. Charites: 227. Demeter: 8. 22. 26. 44. 48. 59. 143. 199. 201. 217. 227. 244. 283; Karpophoros 136?; Megalartos 207; cf. Theai Eleusiniai. Dionysos: 15. 26. 37. 59. 167. 173. 175. 198. 208. 243. 244. 252, 298; Dallios? 104; Demoteles 207; Erikryptos 26; Kathegemon 190; Lenaios 153; Theodaisios 207. Dioskouroi: 51-52. 58. 61. 89. 119. 126. 138. 140. 227. 236. 244; Amyklaioi 61; Soteres 61. Eileithyia: 5. 22. 167. 204. 270; cf. s.v. Artemis. Eirene: 208. 254. Eleutheria: 43. Enodia: 227; Patroa 227; cf. s.v. Nemesis. Eros: 5. 102. 239; Eleutheros 104?. Euangelos: 58. Eumenides: 74. Eurysakes: 16. Ge: 90. 141?. 283; Eukarpia 227; Karpophoros 90; Makaira 90; Meter 90; Pantrophos 189; Telesphoros 90. Glykon: 124. 243. Hades: 23. 227. 293. Hagne Theos: 256. Hekate: 26. 89. 97. 171. 183. 243; Meliteina 140; Sossis 25; Stratia 140-141. Helios: 3. 11. 31. 78. 244; Aniketos 218; Basileus 126; cf. s.v. Zeus. Heliosarapis: 87. Hephaistos: 43. 59. 87. Hera: 22. 26. 37. 59. 72. 104. 170. 172. 244. 293; Archegetis 104; Basileios 104; Dromaia 167; Gamelia 53; Parthenie 104?; Samia 104; Thelxine 293. Herakles: 5. 16. 26. 31. 57. 6061. 72. 83. 87. 89. 95. 126. 141. 152. 160. 171. 227. 240. 244. 258. 268. 272. Hermes: 5. 26. 31. 37. 48. 59. 83. 89. 95. 100. 104. 141. 177. 189. 208. 227. 240. 268. 293; Chthonios 227; Eisagogos 104; Epikarpios 78; Epinikios 78; Korykios 78; Tropaiouchos 78. Hestia: 35. 244. 293; Phamia 140; Prytaneia 87; Timacheia 140. Horai: Polykarpoi 136; Telesphoroi 136. Hosios (kai) Dikaios: 3. 171. 239. Hosioi kai Dikaioi: 126. Hygieia: 22. 87. 95. 167. 212. 227. 235. 240. Kabeiroi: 5. 72. Kairos (Olympios): 293. Kephisos: 21. Kore: 22. 72. 143. 201. 227. 244. 283; cf. s.vv. Persephone, Theai Eleusiniai. Leron/Lerine: 61. Leto: 10. 31. 61. 140. 208. Leukothea: 61. 87. Ma: 121. 283. Mes/Men: 3. 27. 59. 116. 166. 171. 235; Aniketos 235; Askaenos 126. 159. 166. 176; Asylos 239; Tyrannos 240. Messene: 270. Meter: 59. 61. 72. 73bis. 273; Andeirene 53. 126; Dindymene 126; Epikrateia 104; Euangelia 138; Megale 23. 221; Theon 87. 106. 176. 227. 236. 305; Theou 178; Troklimene 218. Meteres: 61. Mnemosyne: 298. Muses: 5. 17. 48. 125. 298. Neleus: 104. Nemeseis: 235. Nemesis: 104. 171bis. 206. 235; Enodia 239. Nymphs: 11. 22. 48. 59. 64. 71. 104. 143. 180; Hydriades 23. Olympios Kairos: 293. Pan: 61. 71. 82. 89. 143. 299. Persephone: 23. 183. 189. 293. Parthenos: 290. Pompaios: 293. Poseidon: 22. 58-59. 
89. 95. 104. 225. 227. 234. 240. 244. 283. 293. 306; Asphaleios 293; Epakrios 104; Helikonios 87. 189; Hippodromios 16; Isthmios 234bis; Patroos 227. Praxidike: 227. Rhome (Dea Roma): 73bis. 111; Archegetis 170. Selene: 78. Theai: Eleusiniai 31. Themis: 87. 227; Agoraia 227. Theoi: 31. 292. 298. 303; Athanatoi 126; Dikaioi 50. 120; Dodeka 73. 241; Hypsistoi 235; Keramietai 292; Pantes 119. 121. 143. 270; Pythioi 61; Samothrakes 104. Theos: Basileus 59; Hypsistos 87. 122. 235. 263; Megas Hypsistos 87. Tritopatores: 74. Tyche: 89. 259; Sebaste 26. Zeus: 5. 7. 14. 28. 33. 37. 53. 59. 78. 89. 119. 126. 170. 172. 176. 234bis. 240. 298; Alastor 293?; Alseios 29; Alsenos 171. 197; Ampel(e)ites 171; Andreas 171; Archegetes 95. 240; Ariou 177; Atabyrios 31; Athenaios 293; Bennios 126. 171; Bronton 27. 171; Chrysaoreus 77; ek Didymon Dryon 179; Dikaiosynos 87; Dolichenos 235; Elasteros 74; Eleutheros 104?; Epikarpios 78; Epinikios 78; Euboulos 22; Eumenes 74; Exakesterios 293; Helios 87; Helios Sarapis 87; Hellenios 293; Herakles 171; Hetaireios 110; Hypatos 31. 293; Hypsistos 31. 85. 227. 235; Ithomatas 269; Karios 31. 291; Karpophoros 136?; Kataibates 227; Kerannios 227; Kimistenos 235, Korykios 78; Labraundos 31; Megistos 126; Meilichios 74. 104. 207; Moiragetes 61; Naos 255; Narenos 235; Nineudios 43; Olbios 259; Olybreus 309; Olympios 2; Opores 283; Orios 293; Oromasdes 57; Osogo 26; Osogollis 31; Ourios 293; Patro(i)os 61. 273; Petarenos 171; Phratrios 16. 207; Phytalmios 58?; Polieus 30. 39. 111. 140. 293; Sarapis 235; Sardendenos 218. 235. 243; Sittakomikos 235. 243; Soter 1. 35. 140. 171. 269-270. 298; Stoichaios 207; Syrgastos 218; Thallos 171; Tropaiouchos 78; Zemeiastes 126

deities, Anatolian: Agdistis: 126; Dodeka Theoi 73. 241; Kakasbos 100. 119; Kybele 226-227. 273; Theos Asbames 4. Celtic: Apollon Grannos: 235. Egyptian: 64. 70. 85. 87. 89. 104. 154. 167. 227. 235. 244-245. 268. 308. Iranian: 57. Roman: Fortuna Augusta 26; Genius Herculi: 152; Iupiter Optimus, Juno, Hercules: 104; Sol Invictus 2. Oriental: 89; Baal: 61; Euporia Thea Belela: 15; Mithras: 96. 218; Sabazios: 31. 258; Thea Syria: 128. Thracian: Bendis 21. 240; Deloptes: 104 Kotytto: 74; Thracian Rider: 139. 218. 235. 285

deities, assimilation of: 57. 89. 194. 309; assimilation of gods and mortals: 61; birthday of: 83; hierarchy of: 235 ( $\Theta \varepsilon \tilde{\omega} \nu \nu \alpha \dot{\alpha} \nu \tau \omega \nu$ $\varrho \alpha \tau \tilde{\omega} \nu$ ); deities as patrons of fertility: 126; of seafaring: 28. 121. 142; of young men: 233; theriomorphic d.: 225

dice-oracle: 126

Dionysiac artist: 61

disease, as divine punishment: 179

divination: 33. 81. 83. 97.126. 183. 205. 245. 281.289. 298

dream: 48. 71. 250. 298; see also Greek index

ear, representation of: 64

Eleusis, Eleusinian mysteries: 31. 66. 283

emperor cult: 1. 25. 40. 42. 76. 87. 104. 112. 141. 171bis. 189. 200. 220. 234bis. 239. 244. 251. 269. 292. 303. 309; identification of a member of the imperial family with a god: 42 (Iulia Sebaste Nea Aphrodite). 141 (Iulia-Leto). 200 (Augustus-Apollon, LiviaArtemis Boulaia). 239 (Tacitus-Zeus)

ephebes: 26. 84. 155. 189. 268

epiphany: 288

epithet: 153.207

excorcism: 80

festival: 26; commemorative: 105; establishment of: 254; founded by individual: 235; funding of: 24. 31. 126; joint: 35; order during f.: 239 
festival, agon: Agrionia: 37; Aktia: 87; Antonea Geteia Olympia: 262 (Laodikeia at Lykos); Antoneinia Pythia: 260 (Rome); Asklepieia: 141. 230 (Kos); Asylia Pythia: 239 (Perge); Augoustia Olympia Oikoumenika: 239 (Perge); Aspis: 87 (Argos); Basileia; 298 (Thebes); Capitolia: 87. 164; Demetrios (agon): 239 (Perge); Dia: 262 (Laodikeia at Lykos); Dia Olympia?: 261 (Rhodes); Dionysia: 141 (Kos); Dionysia kai Antiocheia: 35 (Kyme); for Eirene: 254 (Athens); Ethnike Panegyris: 303 (Lykian Koinon); Hali(ei)a Olympia: 261 (Rhodes); Heraia: 31 (Karia). 104 (Samos); Herakleia: 5; Hermaia: 5; Isthmia: 56; Kallynteria: 232 (Athens); Karneia: 268 (Messene); Koina Asias: 87, 261; Kotyttia: 74 (Selinous); Lenaia: 210 (Athens); Lykaia: 268 (Arkadia); Maleateia: 233 (Sparta); Marollia: 31 (Karia); Naia: 107 (Dodone); Nemea: 56. 87. 298; Olympia: 56. 87. 163. 188. 239. 268 (Elis). 107 (Dion); Oschophoria: 16 (Athens); Ouareios Themis: 239 (Perge); Panathenaia: 87. 232. 254. 286 (Athens); Patrios Megale Themis: 239 (Perge); Philetaireia: 35 (Kyme); Plynteria: 232 (Athens); Ptolemaia: 56 (Delos); Pythaia: 141 (Kos); Pythia: 56. 87 (Delphi). 87 (Antiocheia); Sebasta: 30.87 (Neapolis); Sebasteia kai Nemea: 216 (Argos); Soteria: 35 (Kyme); Soteria Kapetolia: 261 (Laodikeia); Takitios Metropolitios Isokapetolios: 239 (Perge); Tertylleios: 239 (Perge); Thargelia: 186; Themis epi Labioi: 239 (Perge); Theseia: 84; Thesmophoria: 283

festivals, in Aigeai (Kilikia): 259; Antiocheia: 87; Athens: 267; Hierapolis: 87; Ilion: 103; Laodikeia: 87; Mytilene: 87; Nikomedeia: 87; Perge: 239; Philadelpheia: 87; Thyateira: 87; Tralleis: 33. 87; provincial agones: 87

footprints, representation of: 64

foreigners: 9.21

freedman: 1

funeral: 43; public f.: 31 ; in front of the city gates: 73 bis

funerary cult: 1. 26. 29. 31. 88. 91. 104. 109. 124. 143. 157-158. 187; f. legislation: 88; f. foundation: 1. 109; f. imprecation: 4. 26. 43. 78. 87. 104. 124. 126. 171; posthumous dedication of statue: 26.31. 87.268. 292. 303; protection of grave: 93.158. 189

gem: 100. 196. 235; cf. amulet

genitals: 86.171

genos: 16.160

gladiators: 26.41 .87

gymnasion: 5. 26. 29. 31. 83. 109. 182. 189. 268. 298

hands, raised: 171

healing, healing miracle: 31. 71. 249-250; cult of healing deity: 26. 31. 101. 244-245

hero/hero cult: 5. 15. 244. 256; Achilleus: 248. 276; Agamemnon: 271; Aiolos. 48; Androklos: 79; Chrysaor: 77; Darron: 26, Deloptes: 104; Iason: 249; Ikarios: 175; Kassandra: 271; Labos: 239; Maleatas/Maleates: 233; Malos: 233; Maron: 72; Paralos: 256; Pergamos: 85; Souregethes: 285; Theseus: 84; healing hero: 26. 101; heroisation: 17. 35. 61.91.109. 189

Homer: 65. 116. 245

hymn: 102. 104. 116. 198. 288

identity and religion: 27.243

inauguration of temple: 251

incubation: 101. 250

initiation: 65.96 
insence: 189

interaction between religious groups: 4

inventory: 63. 117. 145-149.163. 175. 192

invocation: 1. 126. 235

Jews: 4. 122; Jew as sponsor of pagan festival: 4; Jewish influence: 196

justice, divine: 44-45. 50. 98

key: 226

ktisis myth: 52.79

land, sacred: 17.24 .26 .31

lex sacra: 23. 31. 57. 66. 74. 75. 82. 87. 141. 240. 256

libation: 74

magic: 13. 61. 80. 97. 100. 132-133. 183-184. 196. 295; analogical m.: 129; handbook: 130.

132; love magic: 129; recipe: 279; cf. s.v. amulet, curse, gem, excorcism, Greek words

miracle: 113 ; cf. s.v. epiphany

music, musician: 26

Mycenaean religion: 77. 283

mysteries, of Andania: 62. 268; of Antinoos: 102; of Mithras: 96

myth: 46. 52. 84. 86 (Kassandra). 113. 193 (Alkestis); cf. s.v. hero, ktisis

names, theophoric: 59 (in Samos). 74 (Eumenidotos); related to ritual: 87.251 (Mysta); related to cult offices: 189 (Archieratikos). 234bis (Prophetes); names of gods given to plots of land: 270

necromancy: 81

neokoria: 239

new year, sacrifice: 83

oath: 44. 72. 87. 188. 291. 304; criticism of o.: 126

oracle: 31.61 .75 .124 .189

oratio: 84

Orphics: 20. 65. 221-222

paganism in Late Antiquity: 12. 68. 81. 154

papyri: 153. 205. 245; magical: 80-81. 97. 130. 132-133

participation in cult, limitation of: 140 (limitation to demotai)

personifications: 244; Agathe Elpis: 234bis; Charis: 208; Echo: 208; Eirene 208. 254;

Eleutheria: 43; Eunomia: 208; Opora: 208; Pyretos: 31; Tetartaios: 31; Theoria: 208

philosophy: 102; cf. s.v. Platonism, Pythagoras

phylactery: 130.143. 235. 277; cf. s.v. amulet

piety: 43.104 (Nymphios makes a dedication to the Nymphs); cf. Greek words

pilgrimage: 12

Platonism: 102; Neplatonism: 183

politics and religion: 34.36 .56 .164 .198 .228

pollution: 69.74 .75

prayer: 126. 231. 269. 292; p. for justice: 13. 44-45. 128. 171. 278. 280. 294 
priest: 1; eponymous: 1. 31. 73bis. 111. 269; archiereus: 70.111. 176; archiereus of civic emperor cult: 1. 6. 104. 239. 259; archiereus of provincal emperor cult, in Asia: 40-41. 112. 220. 274; of the Hellenes: 269; in Lykia (Lykiarches): 1; in Pamphylia: 239; archiereia of civic emperor cult: 1. 22; Helladarches: 269; hiereia: 9. 22. 25. 31. 47. 87. 126. 201. 239. 256. 259; hiereus: 11. 26. 30-31. 43. 61. 100. 104-106. 126. 140-141. 162. 170-171. 173-174. 189. 228. 234bis. 239. 247. 256. 272. 276. 291-292. 303

priest: accumulation of priesthoods: 30.87 ; arbitration in legal disputes: 44-45; board of: 292; board of former p.: 141; couples serving as priests: 1. 31; duties of: 87. 140. 256; families of: 31. 239; hereditary: 126; for life: 43. 112. 239. 269; lists of: 31; privileges: 87. 256; sale of priesthood: 67 ; selection by lot: 141 ; voluntary: 31

private and public cult: 101. 109

procession; carrying of images: 104; wearing crowns: 230; processional street: 239

proclamation before ritual: 66

proskynema: 12

prostitution, sacred: 33

punishment, divine: 1. 44. 98. 179. 188; cf. s.v. divine justice

purification: 69. 74. 295

Pythagoras, Pythagoreans: 211. 289

reincarnation: 124

rider god: 3; $c$. deities (Thracian rider)

rite of passage: 226

rituals: 33.44 .74 . 88. 251; funding of: 134; introduction of: 232; proclamation before r.: 66; cf. s.v. banquet, crowning, inauguration, incubation, initiation, libation, new-year sacrifice, oath, sacrifice, supplication, theoria

river god: 104. 118. 170

Rome, Roman influence, Romanisation: 19. 78. 138. 170. 194. 200. 243. 244

ruler cult, Hellenistic: 5. 34. 57. 105. 111. 176. 194. 215. 300; influence of: 31

sacrifice: 5. 12. 26. 31. 39. 73bis-75. 83. 105. 109. 126. 140-141. 172. 189. 202. 231. 239. 256; alternating s. (every other year): 140; distribution of meat: 140-141; funding of: 256; upon enthronisation of an emperor: 231; supplicatory s.: 189; see also animal

sacrificial cake: 47. 256; sacrificial calendar: 140

sanctuary: 301; finances of: 26. 31. 94. 141. 253; fines payable to s.: 31. 34. 78. 104. 140. 188189; networks of s.: 247; participation in: 140; political centre: 14. 107. 291; open-air s.: 2; protection of sacred property: 140; religious centre: 31. 291; revenues: 26. 176. 185186; and transhumance: 107; see also asylia, inventory, land (sacred), temple state

slave: 1. 43; dedication of: 106; sacred s.: 104; and supplication: 275

sceptre of god, erection of: 44. 98; carrying of: 53

snake: 26.249

society and religion/ritual: 9. 15. 45. 88. 96. 98-99. 294

soul: 156

spirit, avenging: 74; evil: 69

statue: 150; cult: 5. 63; dedication of an image of a god to another god: 26. 61. 71. 177. 239

dedicatory: 26; auction of: 134; dressing of: 232; manumission in front of a s.: 229; portable: 243; prohibition against touching a s.: 175 ; dedication of s. as punishment: 188 
supplication: 189. 275

sword, as divine symbol: 77

syncretism: 27. 57. 81. 89.196. 243

temple, conversion: 189; opening: 105; inauguration: 251

temple state: 27

theoria, theoros: 30. 75. 108. 230. 238; theorodokos: 234. 247

theosebeis: 4.122

theurgy: 97.183

torch-race: 104.155

tradition: 24. 31.93

vocabulary, religious: 18 , Jewish: 4; ambiguity of: 4. 11. 109. 165

vow: 2. 43-44. 61. 257; see Greek index

war: 31. 105. 242. 298

water: 101

weather magic: 6.184

wine: 31.180

women and religion: 22. 33. 188; (cult) association of: 15; archieranistria: 272; participation in agones: 301; prohibition against participation in sacrifice: 140; see also priests (hiereia)

\section{Greek words (a selection)}

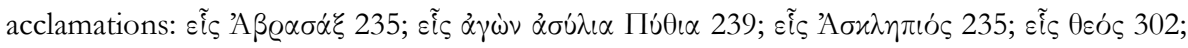

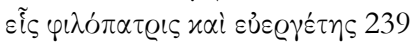

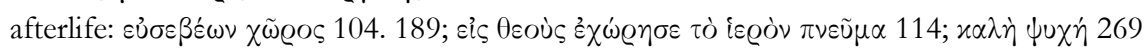

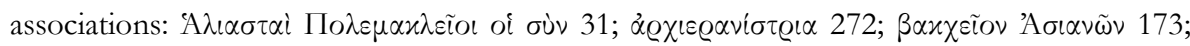

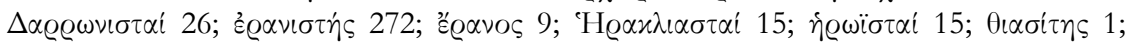

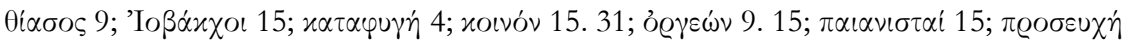

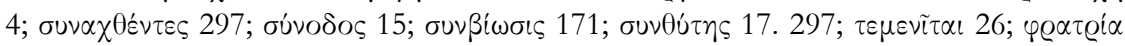
26

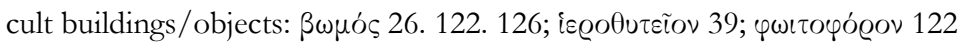

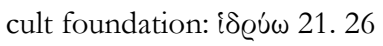

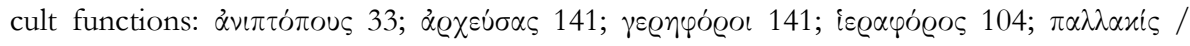

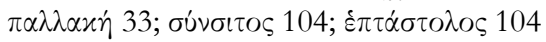

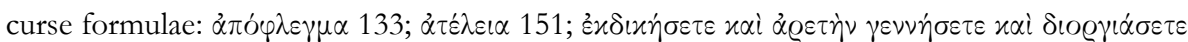

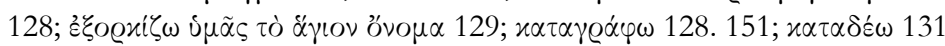

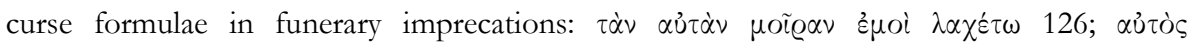

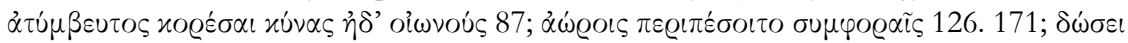

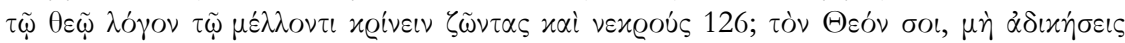

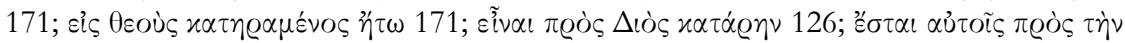

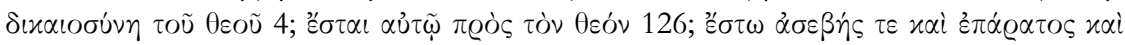

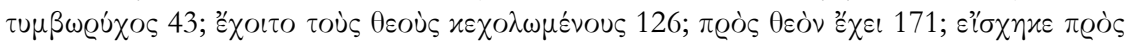

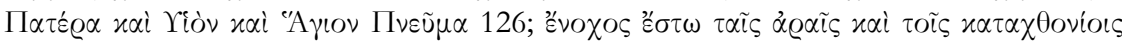

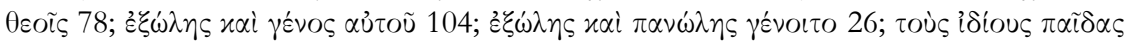




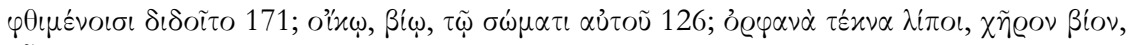

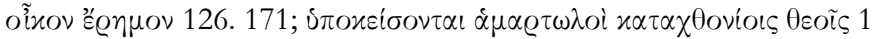

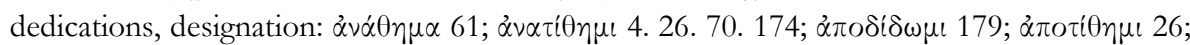

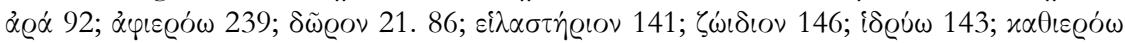

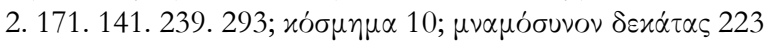

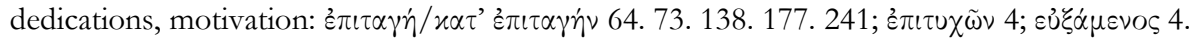

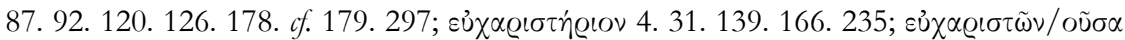

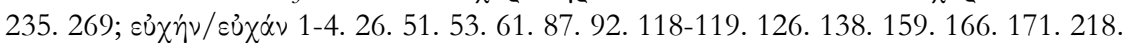

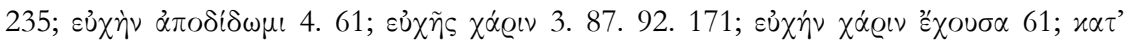

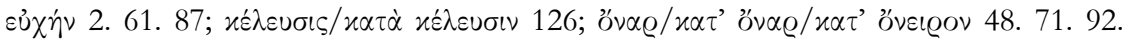

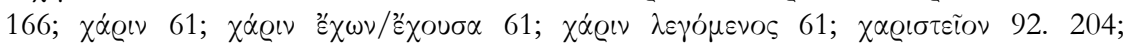

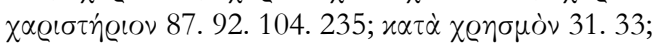

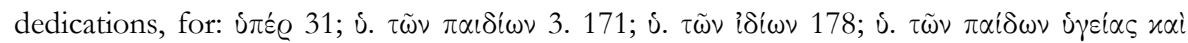

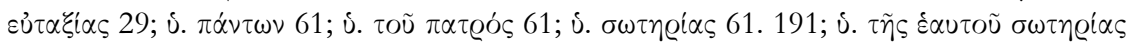

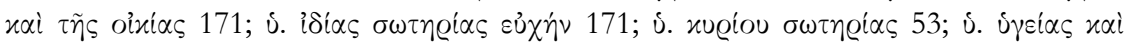

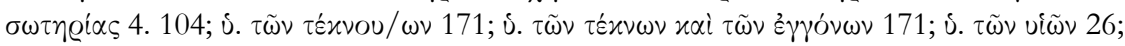
ن. $\tau \tilde{\omega} \nu$ i $\pi \alpha \varrho \chi \delta ́ v \tau \omega \nu 171$

divination: $\lambda o ́ \gamma \iota \alpha 61$

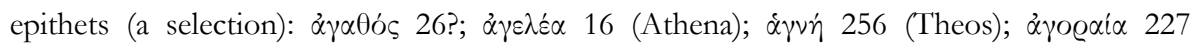

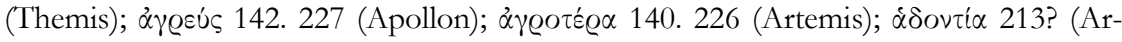
temis); $\alpha \delta \varrho \alpha ́ \sigma \tau \varepsilon ı \alpha 226$ (Artemis); $\alpha \theta \dot{\alpha} \nu \alpha \tau o \varsigma 126$ (Apollon, Helios); $\alpha \lambda \alpha \dot{\alpha} \sigma \omega \varrho 293$ (Zeus);

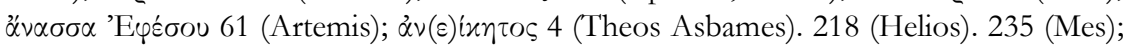

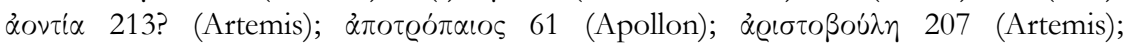

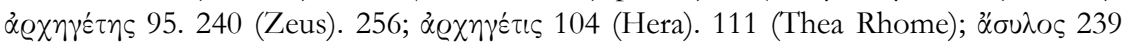

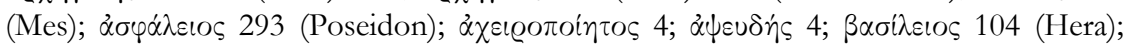

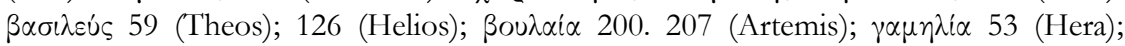

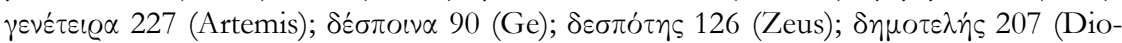

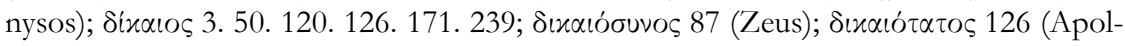

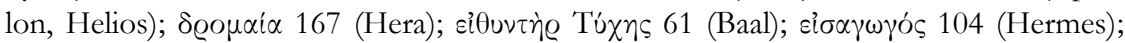

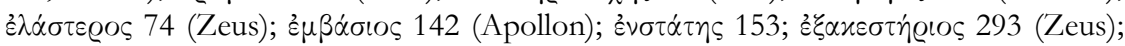

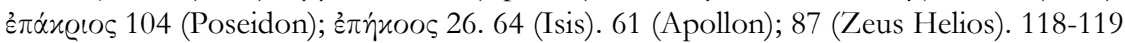
(Ares). 120 (Theoi Dikaioi). 121 (Ma). 138 (Dioskouroi). 218 (Asklepios, Hygieia). 235

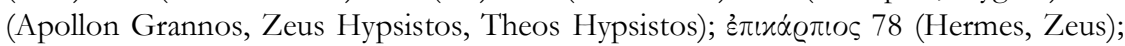

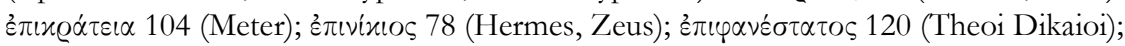

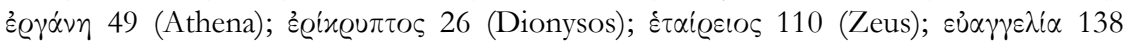

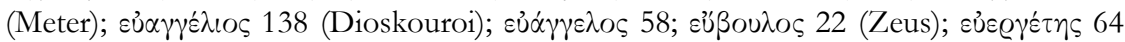

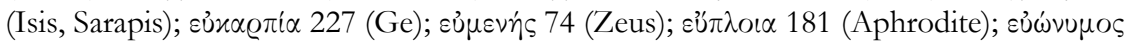

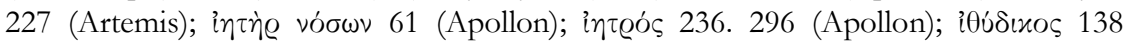

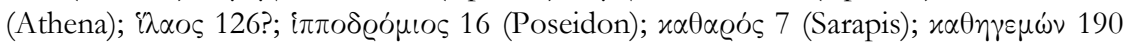

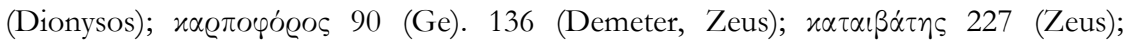

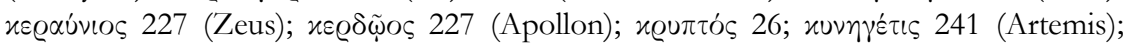
xu@ía 104 (Hera). 128 (Thea Syria); xú@ıৎ 70 (Tithoes). 122 (Theos Hypsistos?). 128.

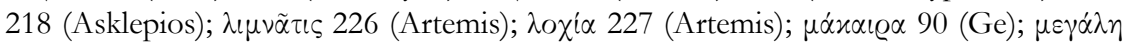

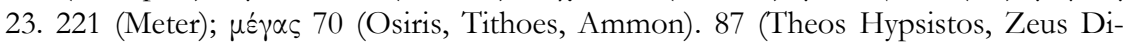

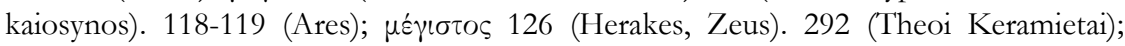

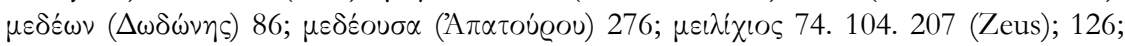

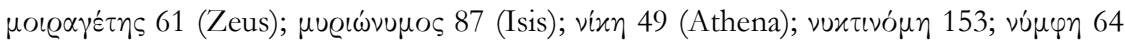




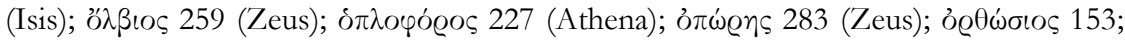

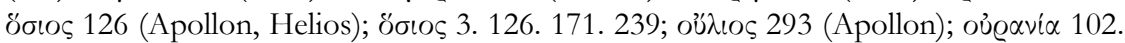

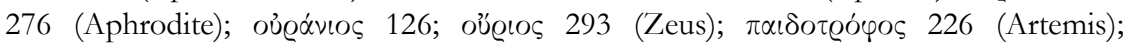

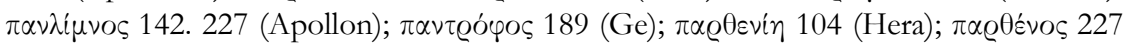

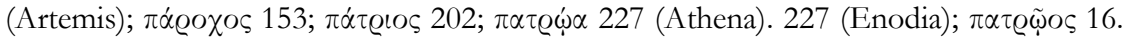

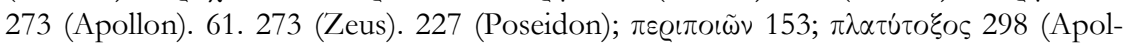

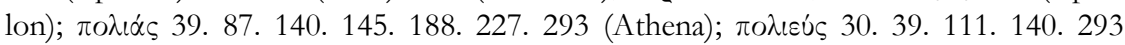

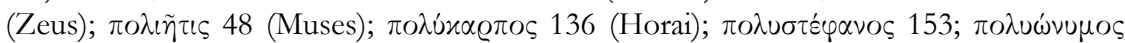

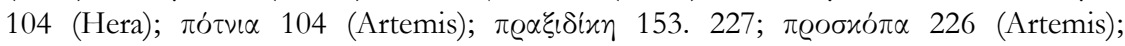

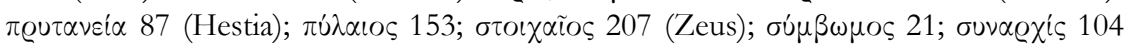
(Aphrodite); $\sigma \dot{\omega} \zeta \omega \nu 118$ (Mizoares). 126 (Apollon); $\sigma \omega \dot{\tau} \varepsilon\llcorner\propto \alpha 226$ (Artemis). 87.140

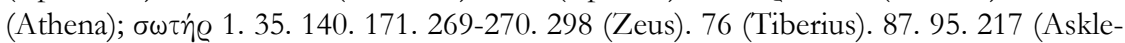

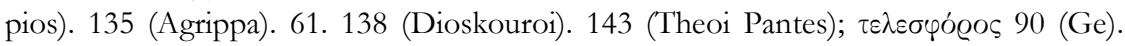

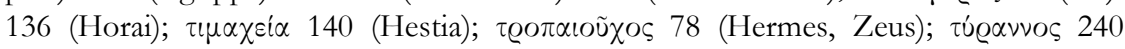

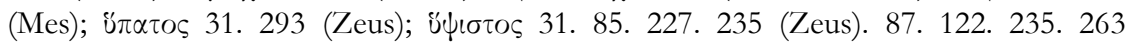

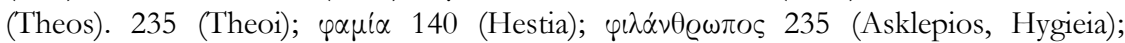

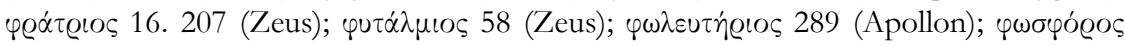

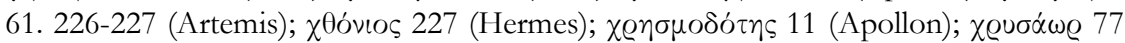
(Apollon, Artemis, Demeter)

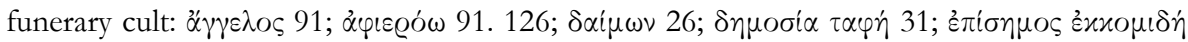

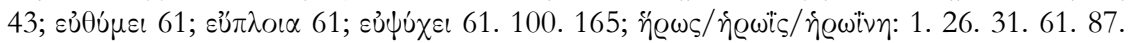

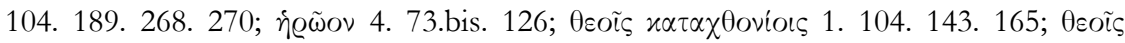

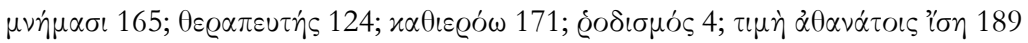

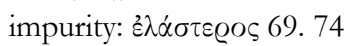

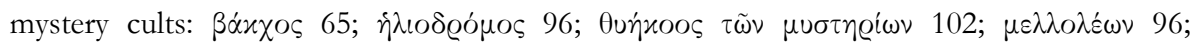

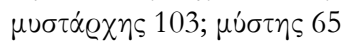

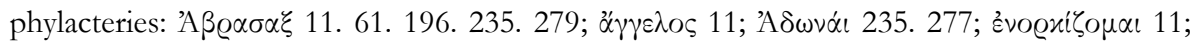

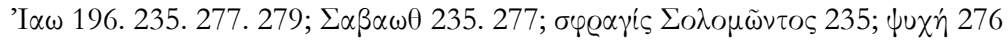

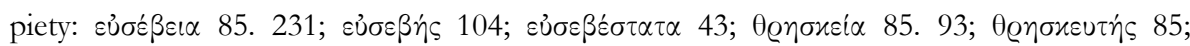

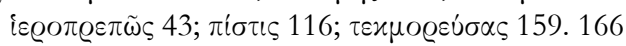

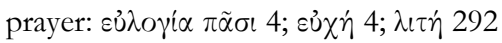

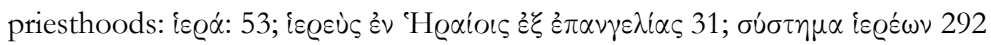

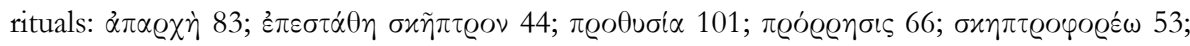
$\sigma \pi \lambda \alpha \nu \chi \nu \varepsilon \dot{\omega} \omega 83$

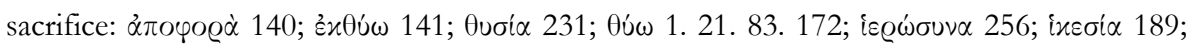

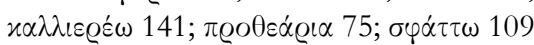

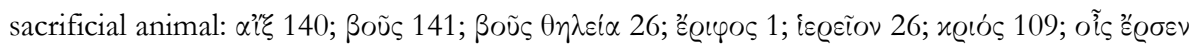

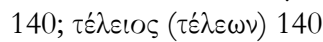

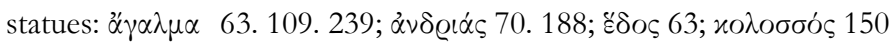

1) M. ADAK - S. ŞAHIN, "Neue Inschriften aus Tlos", Gephyra 1 (2004), p. 85-105 [BE 2006, 387]: Ed. pr. of 21 inscriptions from Tlos. An altar was dedicated to Zeus Soter (8, Hellenistic?). Two other dedications are addressed to Artemis Kombike, who was widely wor-

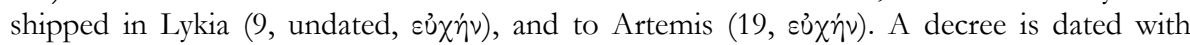
reference to an eponymous priest $(1$, mid-3rd cent.). A posthumous honorary inscription was set up for Demeas who had occupied many offices including those of Lykiarches and 


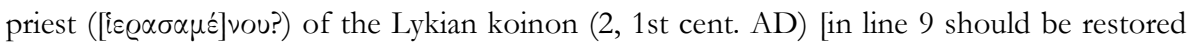
$\grave{\varepsilon}[\nu] \dot{\alpha} \pi O \varrho[i] \alpha, \sigma[\varepsilon i \tau O \nu]$, rather than $\dot{\varepsilon}[\xi] \dot{\alpha} \pi \circ \varrho[i] \alpha \varsigma[\sigma \varepsilon i \tau \omega \nu]]$. An honorary inscription mentions a man and his wife who served as high priest and priestess of the emperor cult $(5,2 \mathrm{nd} / 3 \mathrm{rd}$

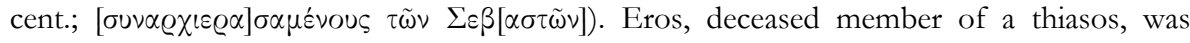
posthumously honoured by other members of his cult association ( $\varepsilon \pi i \tau \tilde{\varphi} \dot{\varepsilon} \alpha \nu \tau \tilde{\omega} \nu \theta \varepsilon \alpha \sigma \varepsilon i \tau \eta$

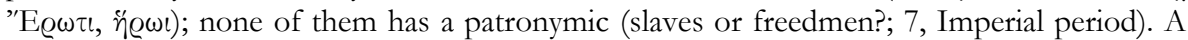

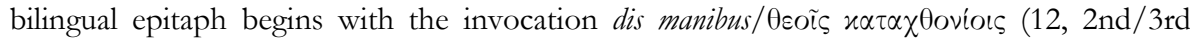
cent). A man's epitaph, written on a funerary altar, obliges the inhabitants of a house to offer him an annual sacrifice of a beautiful he-goat on the 6th of Hyperberetaios; if they do not, they would be punished by the gods of the underworld $(17,2$ nd/3rd cent.; $\varepsilon \pi i \tau \tilde{\omega}$

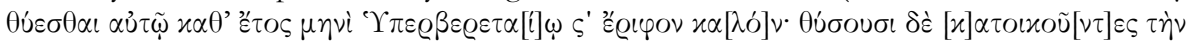

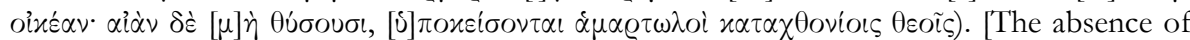

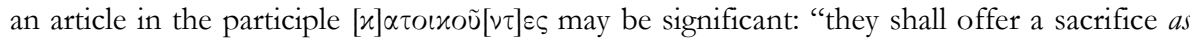
long as they live in the house (not "those who live in the house shall offer a sacrifice"). This obligation may apply to freedmen, slaves, or threptoi who are given the right to live in the deceased man's house under the condition that they take care of the funerary cult; for parallels see, e.g., EBGR 2001, 82; 2002, 117]. [AC]

2) M. ADAK - N. TÜNER, "Neue Inschriften aus Olympos und seinem Territorium", Gephyra 1 (2004), p. 53-65 [BE 2006, 27, 398]: Ed. pr. of six inscriptions from Korykos/ Olympos (Lykia). A woman made a dedication to Artemis Kitaneurissa in fulfilment of a vow (1, 2nd/1st cent.; $\varepsilon \dot{u} \chi \alpha \dot{\alpha})$ ); the epithet of Artemis derives from Kitanaura, a city c. $30 \mathrm{~km}$

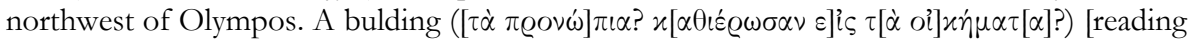
and restoration are uncertain] was dedicated to Zeus Olympios by a man and a woman in fulfilment of a vow (2, 2nd/3rd cent.; $\varkappa \alpha \tau^{\prime}$ sủ $\left.\chi \eta^{\prime} v\right)$. Two dedicatory inscriptions, inscribed by Roman soldiers on the rock in and near a niche in a small sanctuary, are addressed to

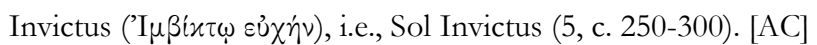

3) N.E. AKYÜREK ŞAHIN, "Neue Weihungen für Hosios und Dikaios", Gephyra 1 (2004), p. 135-148 [BE 2006, 404]: Ed. pr. of 7 new dedications to Hosios kai Dikaios (4 stelae and 3 altars) from Phrygia (2nd/3rd cent.). The monuments are decorated with representations of Hosios kai Dikaios in relief $(1-3,5)$; Mes (?) is added in one of them (4), another god on a chariot in another (6). The most elaborate iconography is found on an altar dedicated by the village of the Korosokometai (5); on three sides of the altar there are representations accompanied by labels of Hosios Dikaios, Apollon (represented on horseback), and Helios.

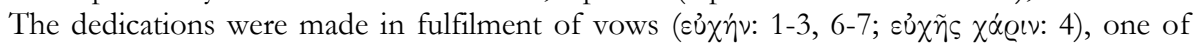
them for the well-being of the children of the dedicants (3: $\delta \pi \dot{\varepsilon} \varrho \tau \tilde{\omega} \nu \pi \alpha \iota \delta i \omega \nu)$. [AC]

4) W. Ameling, Inscriptiones Judaicae Orientis II. Kleinasien, Tübingen, 2004: Although this volume is dedicated to the epigraphic testimonia for Jewish communities and Jews in Asia Minor, nevertheless it is of great significance for understanding the interaction between religious groups in the Imperial period, the existence of a distinctive Jewish vocabulary (e.g., $\varepsilon \dot{u} \chi \dot{\eta}$ in the nominative, $\varepsilon \dot{\jmath} \lambda \circ \gamma(\alpha \pi \tilde{\alpha} \sigma \iota)$ and the convergence of religious phraseology which

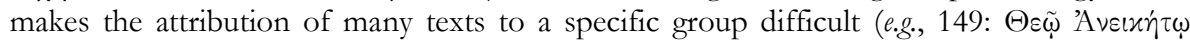

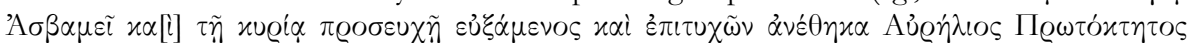

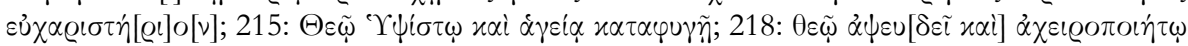

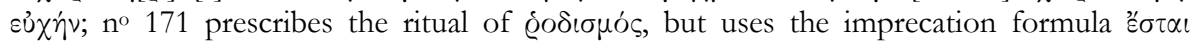

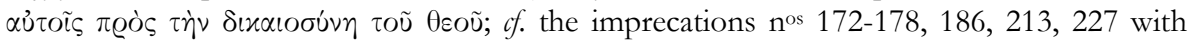
references or allusions to the Old Testament; see also $n^{\circ} 230$ ). In the introductory chapter A. cautiously addresses the problem of whether inscriptions mentioning Theos Hypsistos and the theosebeis reveal Jewish influence (p. 13-20: cf. $\mathrm{n}^{\circ}$ 6). [In this collection there are many 


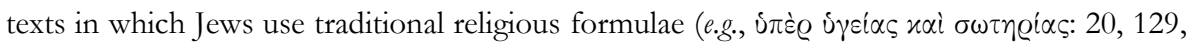

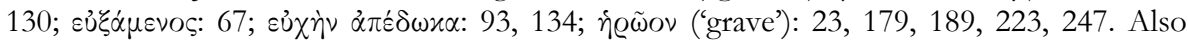
remarkable is the appearance of a Jew as a sponsor of the Dionysia in an epidosis list in Hellenistic Iasos (21)]. The corpus contains five amulets which may be Jewish. [AC]

5) S. Aneziri - D. DAmaskos, "Städtische Kulte im hellenistischen Gymnasion", in D. KAH - P. SCHOlZ (eds.), Das hellenistische Gymnasion, Berlin, 2004, p. 247-271: Making ample use of the relevant epigraphic and archaeological evidence, A.-D. discuss in their thorough study the various cults that were practiced in Hellenistic gymnasia. According to their clear definition, 'cults in a gymnasion' can be recognised through the existence of an altar inside a gymnasion which made the offering of sacrifices possible. Additional elements, in some cases, were a (cult) statue or even a temple. Hermes and Herakles are the gods most often worshipped in Hellenistic gymnasia. The festival of the Hermaia must have existed in every gymnasion, while the Herakleia were less common (IG XII.9, 952; IG XII Suppl. 121 and 554). Very often the two festivals were celebrated jointly (IG XII.3, 331; IG XII.5, 818; I.Sestos 1; MAMA VI 173; CIG 3087). Sacrifices to these gods were an integral part of the festivals (IG II ${ }^{2}$ 1227), but they could also be performed separately (IG IV.1, 4). Other divinities whose cult is attested in gymnasia include Apollon with the Muses (e.g., Syll. ${ }^{3}$ 577), Eros and Anteros, Asklepios (e.g. SEG XXVI 139), Eileithyia (e.g. IG XI.2, $287 \mathrm{~A}$ ), the Kabeiroi (e.g., IGR IV 294), and Zeus (e.g., IG II $\left.{ }^{2} 2360\right)$. The cult of local mythical heroes inside a gymnasion was rather uncommon (e.g., IG $\mathrm{II}^{2} 2360$ ). References to kings in inscriptions concerning cult activity in gymnasia are ambiguous, since it is not always clear whether we are dealing with an actual cult of the sovereign or with rituals performed for the king

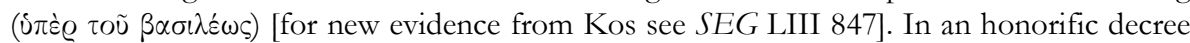
for Diodoros Pasparos in Pergamon there is an unequivocal reference to sacrifices on the altar of the Attalids (IGR IV 294). Besides Hellenistic kings, other human recipients of cults in Hellenistic gymnasia were former benefactors (e.g., IG XII.3, 202) [cf. infra no 265]. On exceptional cases a cult for a benefactor was established in his lifetime (e.g., Lyson in Xanthos: SEG XLVI 1721; Diodoros Pasparos in Pergamon: IGR IV 292-294). With the exception of Titus Flamininus (Plut., Flam. 16, 3), there were no cults of Roman citizens in Hellenistic gymnasia. [JM]

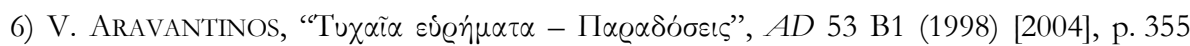
[SEG LII 510]: A fragment of a Hellenistic honorary inscription for a benefactor was found in Thebes (p. 355). The text refers to the reconstruction of the theatre, mentioning the proskenion and a statue. One of the offices occupied by the benefactor may have been that of archiereus. [AC]

7) Z. ARCHIBALD, “A River Port and Emporion in Central Bulgaria: An Interim Report on the British Project at Vetren”, ABSA 97 (2002), p. 309-351 [SEG LII 711]: A. discusses the content of a pit in which two Panathenaic amphoras with graffiti were found (Pistiros, Thrace). The pit did not contain waste, but symbolic items, possibly in the context of a

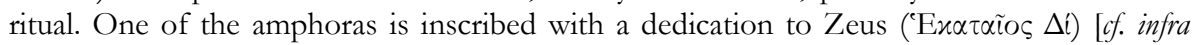
no 72]. [AC]

8) R. ARENA, Iscrizioni greche arcaiche di Sicilia e Magna Grecia. Iscrizioni di Sicilia II. Iscrizioni di Gela e Agrigento, Alessandria, 2002 [SEG LII 886]: The first edition of this corpus of the Archaic inscriptions of Gela and Akragas was presented in EBGR 1993/94, 10. The revised edition unfortunately has a different numbering, even though almost all the texts are the same [for concordances and analysis see R. TYBOUT in SEG LII 886]. The only new texts of a religious interest are graffiti on Attic skyphoi dedicated to Demeter and found in the sanctuary of Demeter at Akragas (early 5th cent.). [AC] 


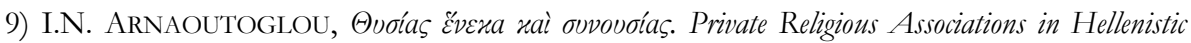
Athens, Athens, 2003 [BE 2004, 141]: A. dedicates this monograph to the social and legal aspects of cult associations in Hellenistic Athens, primarily in the light of the epigraphic evidence [for the Roman period see infra $\mathrm{n}^{\circ}$ 15]. He discusses in detail their designations

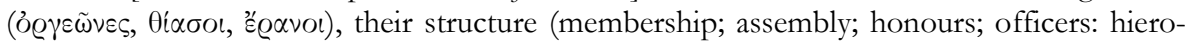
poioi, epimeletai, grammateus, tamias, hiereia), their property, their interaction with society, their significance for foreigners living in Athens, and their reproduction of contemporary hierarchical structures and social phenomena such as patronage, benefactions, and solidarity. In two appendices A. presents a list of the relevant inscriptions (p. 171-185) and a list of the known members of associations (p. 187-205). [AC]

10) A. Avram, "An Istrian Dedication to Leto", in The Cauldron of Ariantas, p. 87-91 [BE

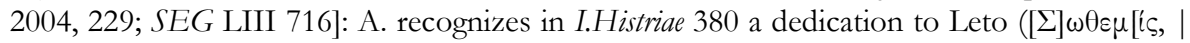

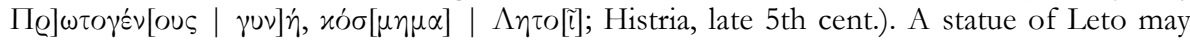
have been dedicated by another relative of Sothemis (I.Histriae 170). The cult of Leto is attested in Histria and Berezan, but not in other Milesian colonies. [AC]

11) M. AYDAŞ, "New Inscriptions from Asia Minor", EA 37 (2004), p. 120-124 [BE 2005, 427]: Ed. pr. of six inscriptions from Karia and Phrygia (1-6) and improved edition of a seventh text (7). The texts include a dedication to the Nymphs (1, Aydin, 4th cent.); an altar of Apollon Chresmodotes (3, Kys, Hellenistic); an honorary decree for a priest (?) of Helios (?) by the people of Trapezopolis (7); an early Christian text on a small bronze scroll in a

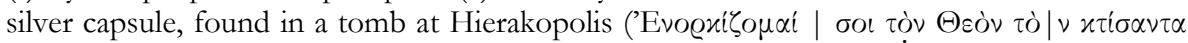

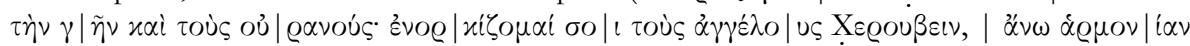

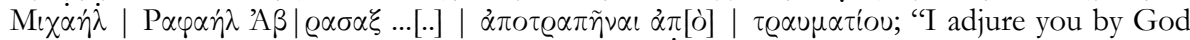
the builder of the earth and heaven. I adjure you by the angels, Cherubim, the harmony of above [of heaven?], Michael, Raphael, Abrasax, ... , so that wound is averted"). [This is an amulet containing a prophylactic text; for such capsules containing amulets and found in graves see EBGR 1999, 82. The reference to Abrasax makes its attribution to a Christian doubtful; the Jewish god was also perceived as ktistes: see EBGR 2000, 127 = SEG L 1233. The ambiguous vocabulary, with Jewish, Christian, and pagan infuences, is common in this period (cf. supra $\left.\left.\mathrm{n}^{\circ} 4\right)\right]$. [JM]

12) R.S. BAgnAlL, "The Last Donkey Sacrifice at Deir el-Bahari”, JJP 34 (2004), p. 15-21 [BE 2005, 602]: Four proskynemata from the upper terrace of the temple of Hatshepsut at Deir el-Bahari (SEG XLI 1612-1615) attest to pagan cult activity in the first half of the 4th cent. AD. All four refer to the visits of a college of ironworkers of Hermonthis at Deir elBahari during which the group sacrificed a donkey before the god. One of the texts (SEG XLI 1614) was dated to 27-28 (?) December 357. This would imply the existence of postCostantinian pagan religious activity in the Thebais. B. demonstrates the enormous inherent chronological difficulties of this text and suggests an earlier date (AD 327/8). [JM]

13) M. BAilliot, "Magie romaine et méthodologie", Archaeologia Bulgarica 7.1 (2003), p. 71 81: After a critical review of early research on the relationship between magic and religion (J.G. Frazer, M. Mauss, H. Hubert) and taking into consideration recent research on 'prayers for justice' and the relationship between devotio and defixio in Latin sources, B. defends the case for a close relationship between magic and religion. B. points to the evidence provided by images on curse tablets (representations of divinities whose name does not appear in the text, representations of the victim) and by historiolae for the existence of different magical rituals. [AC] 
14) H. Baitinger - B. Eder, "Hellenistische Stimmarken aus Elis und Olympia: Neue Forschungen zu den Beziehungen zwischen Hauptstadt und Heiligtum", JdI 116 (2001) [2002], p. 163-243 [SEG LI 524]: B.-E. present a catalogue of 294 inscribed bronze discs found in Elis and Olympia (3rd/2nd cent.). They are inscribed with abbreviations (the

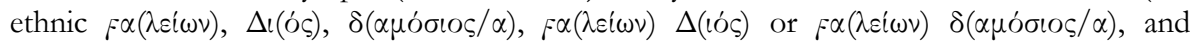
perhaps numbers. The authors plausibly interpret them as ballots for voting in the theatre of Elis and in the bouleuterion at Olympia. In light of this evidence, B.-E. re-examine the close administrative and economic relations between the city of Elis and the sanctuary of Olympia, arguing that under the control of Elis the sanctuary served as a central place in south Elis and as an economic and administrative centre. [JM]

15) M.-F. BASLEZ, "Les notables entre eux. Recherches sur les associations d'Athènes à l'époque romaine", in L'bellénisme d'époque romaine, p. 105-120: The author discusses the evidence provided by several inscriptions for cult associations in Roman Athens (1st cent. BC-3rd cent. AD) [on the Hellenistic period see supra no 9]: koinon of the Heroistai (IG II ${ }^{2}$

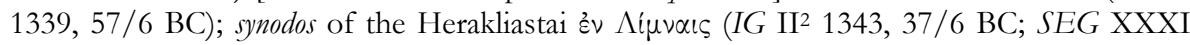
122, AD 121/2); unknown association of women (IG II ${ }^{2} 1346$, 1st cent. AD); orgeones of a goddess (IG II ${ }^{2}$ 1351, ca. AD 170); Iobakchoi (IG $I^{2}$ 1368, after AD 178); Paianistai of Asklepios in Mounychia (IG II ${ }^{2} 2963$, AD 212/3); orgeones of Euporia Thea Belela and the gods around her $\left(I G I^{2} 2361,2 \mathrm{nd} / 3 \mathrm{rd}\right.$ cent. AD). A prosopographical study demonstrates that the members of these cult associations belonged to a well-educated class, but were not always part of the Athenian elite. The associations discussed by B. were devoted mainly to Dionysiac or heroic cults. [JM]

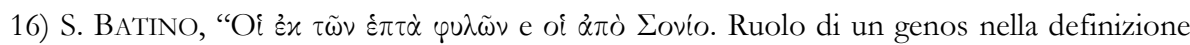
degli spazi sacri nella città e nel suo territorio", $A S A A 81$ (2003) [2004], p. 83-152: Based on the epigraphic evidence (LSCG Suppl. 19; Agora XIX L4b), but also making ample use of the archaeological material and the literary sources, B. offers a detailed overview of the Attic cults (Aglauros, Apollon Patroos, Athena Agelaa, Athena Skiras, Herakles, Eurysakes, Poseidon Hippodromios, Zeus Phratrios) and festivals (Oschophoria), in which the genos of the Salaminioi was intensively involved. B. suggests that the Alcmaeonids were the leading family of the genos of the Salaminioi. [JM]

17) M.C. BEAulieu, "L’héroïsation du poète Hésiode en Grèce ancienne”, Kernos 17 (2004), p. 103-117: In a study of the (primarily literary) evidence for the heroisation of Hesiod, B. adduces (p. 112f.) the boundary stone of the sacred land of a cult association in Thespiai (IG

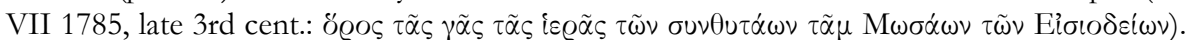
She rightly points out that this inscription refers to sacrifices offered to the Muses, and consequently cannot be regarded as evidence of a cult of Hesiod or of an association of rhapsodes. [The text simply states that the cult association worshipped the Hesiodian Muses, i.e., the Muses mentioned by Hesiod or the Muses who appeared to Hesiod]. [AC]

18) N. Belayche, "Religions de Rome et du monde romain", Annuaire de l'École Pratique des Hautes Études, Section des sciences religieuses 111 (2002/03), p. 238-245: B. sketches the significance of the study of 'confession inscriptions' for understanding religious trends in the Imperial period, focusing on their vocabulary and the images, and the evidence they provide for the personal communication beween men and gods. [AC]

19) N. BeLAyChe, "Les formes de religion dans quelques colonies du Proche-Orient", ARG 5.1 (2003), p. 157-179: Through a study of how the foundation of Roman colonies in Judaea and Palestine (Berytos, Caesarea Maritima. Aelia Capitolina, Ptolemais, Tyros) affected their cults, B. shows the diversity of religious practices in the Roman East. Berytos imported the 
Roman pantheon (e.g., Marsyas of the comitium, Liber Pater, Mater Matuta) and copied Roman institutions (pontifex, flamen); a similar development may be observed in Aelia Capitolina. Caesarea Maritima used the Roman calendar to honour traditional deities; local traditions remained strong in Ptolemais and Tyros, while Gaza had a Greek pantheon. [Cf. EAD., Iudaea-Palaestina. The Pagan Cults in Roman Palestine (Second to Fourth Century), Tübingen, 2001, and EAD., "Tychè et la Tychè dans les cités de la Palestine romaine", Syria 80 (2003), p. 111-138, on different concepts of the cult of Tyche in Roman Palestine]. [AC]

20) A. Bernabé, Poetae Epici Graeci. Testimonia et fragmenta. Pars II. Fasc. 1, Munich/Leipzig, 2004: B. presents an invaluable collection of the 'Orphic' lamellae and other inscriptions influenced by Orphism with new critical editions of the texts and commentary [cf. infra no 222]. [AC]

21) L. BESCHI, "Culti stranieri e fondazioni private nell'Attica classica: Alcuni casi”, $A S A A$ 80 (2002) [2003], p. 13-42 [BE 2005, 73]: Based on all available sources B. discusses three cults which were introduced by foreigners or by individual Athenians in Athens: the cult of Bendis which was transformed from a cult primarily attended by metics into an official polis cult (IG I $\mathrm{I}^{3}$ 136, 369 line 68, 383 line 143); the cult of Asklepios introduced from Epidauros to Athens ( $I G \mathrm{II}^{2} 4960 \mathrm{a}-\mathrm{c}, 4961$ ); and the sanctuary of Kephisos at Phaleron that was probably established privately (IG II 24547 ; IG I3 986Ba, 987). [B. suggests that the sanctuary

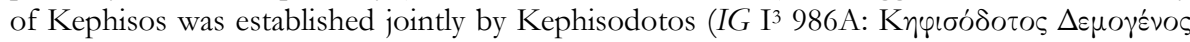

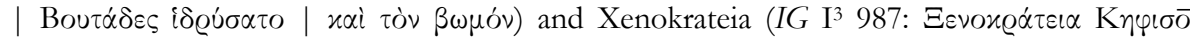

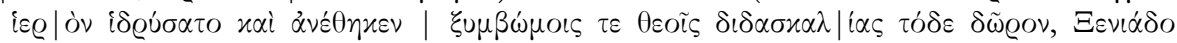

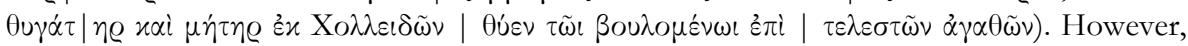
only Xenokrateia's dedication explicitly refers to the foundation of a sanctuary (bieron) for Kephisos; although R. PARKER, Polytheism and Society at Athens, Oxford, 2005, p. 430 note 49, has recently rejected the idea that Kephisos' sanctuary was founded by Xenokrateia, the text is unequivocal]. [JM]

22) A. Bielman-SÁnCHEZ, "Égéries égéennes. Les femmes dans les inscriptions hellénistiques et impériales des Cyclades", in L'bellénisme d'époque romaine, p. 195-213: B. discusses different aspects of female presence in the religious, social, and political life in the western and southern Cyclades (5th cent. BC-4th cent. AD). C. 40 inscriptions attest the role of women as dedicators and priestesses. It is not surprising that the majority of the female dedications was addressed to female deities (Demeter, Kore, Athena, Artemis, Hera, and the Nymphs), while offerings to male deities were rare. In these cases the god appears in the company of goddesses (e.g., Zeus Euboulos, Demeter, and Kore: IG XII.7, 76, Amorgos, 4th cent.; IG XII.5, 227, Paros, 1st cent. BC/1st cent. AD; Amphitrite and Poseidon: IG XII.5, 918-923, Paros, 2nd-1st cent.). In Paros, female dedications to Eileithyia, made by one or two women jointly or by a mother and her children, are numerous (IG XII.5, 187, 189-198, 1022, 1023). By contrast, female dedications to Asklepios and Hygieia in Paros (IG XII.5, 160, 164-168, 170-172) were made by couples and almost exclusively for the sake of male children. Priestesses are known through inscriptions in Amorgos (IG XII.7, 4, 4th cent.), Keos (IG XII.5, 575, 4th cent.), Andros (IG XII.5, 726, Hellenistic), Ios (IG XII.5, 1012, 2nd cent.), Paros (IG XII.5, 275 and 1029, 1st cent. AD), and Syros (SEG XXXVIII 829, 1 st/2nd cent. AD). An inscription from Siphnos [not from Paros as stated by B.] attests the existence of a high priestess (IG XII.5, 487). [JM]

23) M. BILE, "Quelques épigrammes crétoises ( $2^{\mathrm{e}} \mathrm{s}$. av. $-5^{\mathrm{e}} \mathrm{s}$. ap. J.-C.)", in L'épigramme, p. 123-141 [SEG LIII 936, 950, 979]: In a short study of the linguistic features of Cretan epigrams, mostly funerary, B. discusses and translates the metrical cult regulation of the temple of Megale Meter in Phaistos (I.Cret. I, XXIII, 3; p. 125-127) [with no knowledge of the 
recent studies summarized in EBGR 1993/94, 47; 1997, 375; 2000, 198]. She suggests

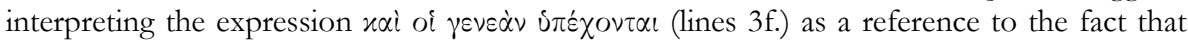
the worshippers of Megale Meter committed their descendants to her cult and to her protection [cf. infra $\mathrm{n}^{\circ}$ 221]. B. also discusses the designation 'A $\gamma \varepsilon \sigma i \lambda \alpha \varsigma$ for Hades and the

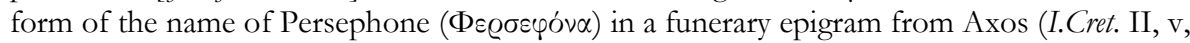
49; p. 129f.). Commenting on a funerary epigram from Itanos (I.Cret. III, IV, 39; p. 134), she

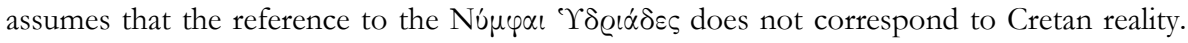
[For Nymphs related to water in Crete see, however, A. CHANIOTIS, in J. SCHÄFER (ed.), Amnisos, Bonn, 1992, p. 86f., and K. SPORN, Heiligtümer und Kulte Kretas in klassischer und hellenistischer Zeit, Heidelberg, 2002, p. 389]. [AC]

24) A.M. Biraschi, "A proposito di affitti di proprietà sacre in Attica", PP 59 (2004), p. 429-435: Many Attic inscriptions of the 4th cent. record the leasing of sacred property; a particular group can be attributed to the Lykourgan era. The starting point of B.'s discussion is $I G \mathrm{II}^{2} 2495 \mathrm{~B}$, which states that the time for the payments of the rent should correlate

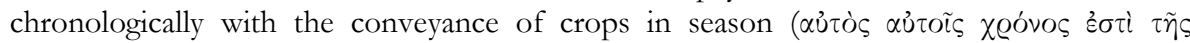

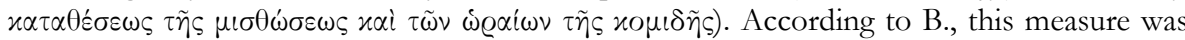
closely connected with the funding of religious ceremonies and fits perfectly the general religious programme of Lykourgos to reorganise Attic religious affairs $x \alpha \tau \dot{\alpha} \tau \dot{\alpha} \pi \dot{\alpha} \tau \varrho \iota$. The aim was a revival of the order according to which the celebration of festivals depended chronologically on the conveyance of crops and not on the payment of the rent ( $c f . L S C G$ Suppl. 10, late 5th cent., which concerns sacrifices funded $\alpha \pi \dot{o} \mu \kappa \theta \theta \omega \mu \dot{\alpha} \tau \omega \nu$ [if Sokolowski's reading is correct]; see also IsOCR., Areop. 29-30). [JM]

25) W. BLÜMEL, "Epigraphische Forschungen im Westen Kariens 2000”, AST 19.2 (2001), p. 157-162 [BE 2003, 472; SEG LII 1028]: B. republishes with new readings an honorary inscription for a priest of Caesar (CIG 2900, Alabanda, Imperial period). A new dedication to Hekate Sossis found in the area of Mylasa (Sossos?) confirms the restoration of this epithet in SEG XLIV 910 (EBGR 1995, 37). [AC]

26) W. BLÜMEL, "Neue Inschriften aus Karien II: Mylasa und Umgebung", EA 37 (2004), p. 1-42 [BE 2005, 431-433; BE 2006, 365]: B. presents briefly 65 new inscriptions from Mylasa and its vicinity (Greek text, occasionally brief commentary, and no translation); almost all of them are inedita. Cults and sanctuaries: A fragmentary inscription (5, Imperial

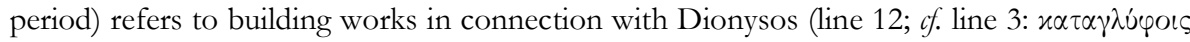

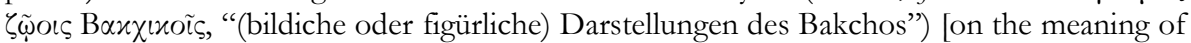

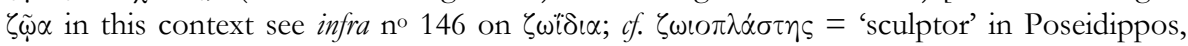
epigr. 62 ed. Austin-Bastianini; the reference to epistyles in line 2 suggests a relief frieze representing not Bakchos but the Dionysiac thiasos]. A Hellenistic lease of land mentions

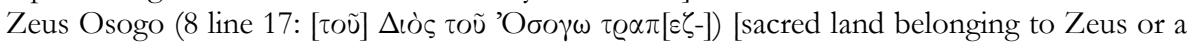
temple bank?]. Another Hellenistic lease of land from Hydrai (?) refers to sacrifices in a fragmentary context (9) [the leases in Mylasa (see I.Mylasa) do not contain regulations concerning sacrifices, but this is the case in a lease from Amos; see EBGR 2002, 10]. A Hellenistic document concerning a delimitation (11) mentions as points of orientation the peribolos [of a sanctuary?] (lines 3, 6, 7) and a road leading to a sanctuary (line 9). An altar

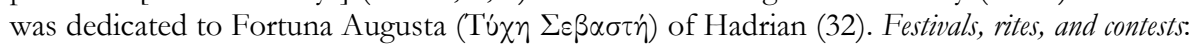
A Hellenistic inscription mentions the kitharist Leodamas in connection with the koinon of the Chrysaoreis (4) [the reference to Dionysos (line 2: $[\Delta \iota 0] v u ́ \sigma \omega \iota)$ and to choruses (line 6:

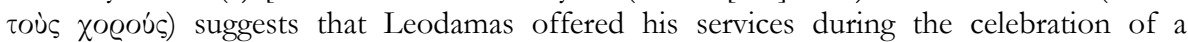
festival]. A fragmentary cult regulation $(13,4$ th cent.) refers to revenues (line 2$)$, the

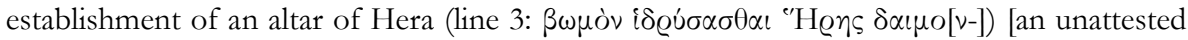


epithet of Hera?] the appointment of a priest, the offering of a sacrifice of cows (line 5 : ßoũ $\varsigma$ $\theta \eta \lambda \varepsilon i \alpha \varsigma)$ [and probably the distribution of the meat of the sacrificial animal (line $6:[\dot{\alpha}] \pi$ '

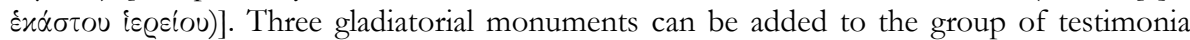
concerning gladiatorial events in Mylasa (27-29; cf. I.Mylasa 531-539). [The name of the gladiator in $\mathrm{n}^{\circ} 29$ (KAП[.]IA $\Delta \mathrm{O} \Sigma$ ) can be read as K $\alpha \pi \pi \dot{\alpha} \delta \circ \xi$ ('the Cappadocian']. A funerary epigram for Achilleus, a victor in $\operatorname{\jmath } \varrho u \theta \mu$ in, is a rare attestation of this discipline (elegant dance or rather a ball-game; of. SEG XXXV 1327) [Eủ@u $\theta \mu$ in was a discipline in the

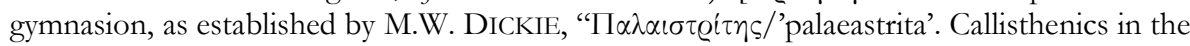
Greek and Roman Gymnasium", Nikephoros 6 (1993), p. 105-151; this is directly attested in

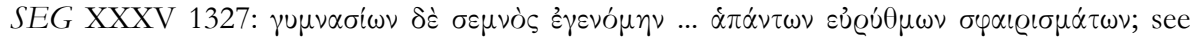
also SEG XL 1163 and XLIII 1215]. Achilleus is represented as a naked athlete, with a

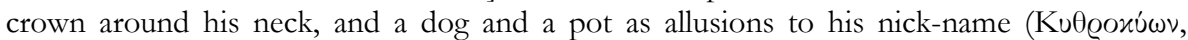

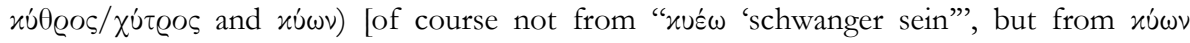
('dog')]. Dedications. A statue of Athena was dedicated to Zeus Osogo by a priest (14 = SEG XLVII 1606; cf. EBGR 2000, 22, Imperial period; notice the expression $\tau \dot{\eta} \nu$ 'A $\theta \eta \eta \tilde{\alpha} \nu$

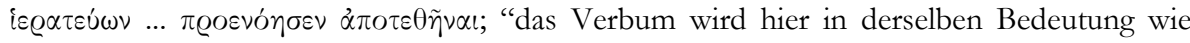
$\alpha \nu \alpha \tau i \theta \eta \mu$ gebraucht"). [The use of a different verb than $\alpha \nu \alpha \tau i \theta \eta \mu$ rather suggests that the acting priest made sure that an already existing statue of Athena was erected (or erected again)]. Eutychos and the $\tau \varepsilon \mu \varepsilon v i \tau \alpha \iota$ [a cult association] dedicated a round altar with a representation of a dolphin on a staff (15, late Hellenistic). A very interesting dedication on a round altar decorated with a snake twisted around a staff ("Aesculapstab") reads: 'Aexn

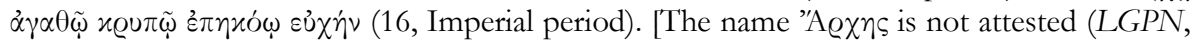

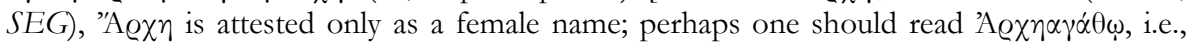
the uncontracted form of the very common 'A $\alpha \dot{\alpha} \gamma \alpha \theta 0$; Arches or Archagathos must have

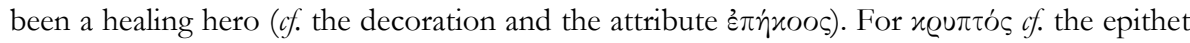

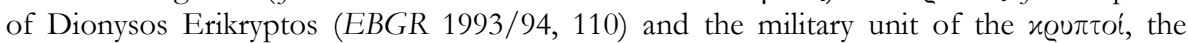
young patrollers in Athens (D. KNOEPFLER, "Les kryptoi du stratège Epicharès à Rhamnonte et le début de la guerre de Chrémonidès", BCH 118 [1993], p. 327-341). The addressee of the dedication may have been a heroised young soldier, worshipped as a healing hero. Many healing heroes were regarded as warriors: e.g., Amphiaraos, Machaon, Podaleirios, possibly Darron (as we may infer from the meaning of the name (Thrason, see infra), Asklepios, and probably Maleatas (see infra $\mathrm{n}^{\circ}$ 233)]. Other dedications are addressed to Demeter (17, Imperial period, ยủxív), [--]e and Hekate (23), Helios (18, Hellenistic,

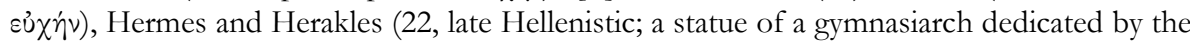
non-citizens for his exceptional generosity in allowing them to receive oil), and to an anonymous deity by Bithys for the well-being of his sons (21, Imperial period, í $\pi \dot{\varepsilon} \varrho \tau \tilde{\omega} \nu$ vi $\tilde{\omega} v$ ) [the form of the monument ("allseits gebrochenes Fragment einer Säule" and the article $\tau$ óv referring to the object of the dedication suggest that it was a round altar ( $\tau$ ò $v$ $\left.\left.\left[\beta \omega \mu \grave{\nu} v \dot{\alpha} v^{\prime} \theta \eta\right] \chi \varepsilon \varepsilon\right)\right]$. Funerary cult: The phratry of the Darronistai dedicated an altar to the

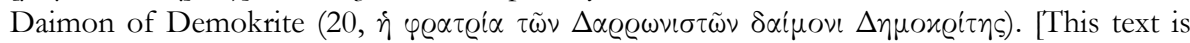
misunderstood by B. It is certainly not an "Ehreninschrift", but a funerary altar dedicated to the spirit of the deceased Demokrite (for this use of $\delta \alpha i \mu \omega \nu$ see the funerary inscriptions

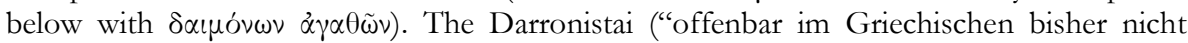
belegt") derive their name from the Macedonian healing hero $\Delta \alpha \varrho \varrho \omega \nu / \Theta \alpha ́ \varrho \sigma \omega \nu$ (see SEG XLIV 546 and EBGR 1993/94, 147; 1999, 97), as M.-J. CARBON, " $\Delta \alpha \varrho \varrho \omega v$ and $\Delta \alpha i \mu \omega v:$ A New Inscription from Mylasa", E $A 38$ (2005), p. 1-6, has pointed out. Carbon is also right in his assumption that $\varphi \varrho \alpha \tau \varrho^{\prime} \alpha$ ('brotherhood') designates a cult association, since the ending $-\iota \sigma \tau \alpha i$ is well attested for cult associations but not for kinship groups, and that this inscription presupposes a heroisation of Demokrite (his study will be summarized in EBGR 2005)]. The fellow ephebes of T. Flavius Protoleon Sophanes dedicated his statue posthu- 
mously (line 5: $\eta_{\varrho} \omega$ os) for eternal commemoration (23 = SEG XLIX 1434) [cf. EBGR 2001,

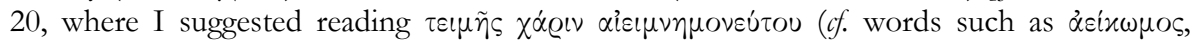

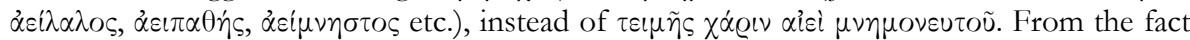
that Protoleon was responsible for the alipterion we may infer that the ephebes dedicated his statue in the gymnasion. For this phenomenon of. infra nos 109 and 298]. Many epitaphs,

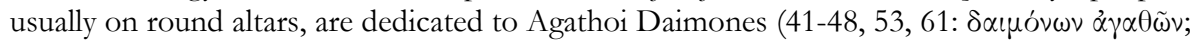

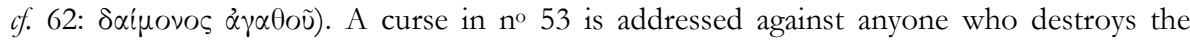

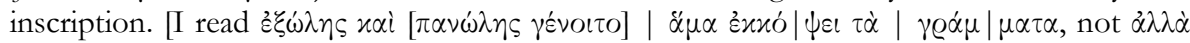

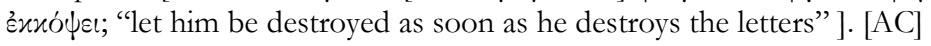

27) L. BOFFo, "Senso religioso e senso etnico fra gli Anatolici in epoca ellenistica e romana", in M. Mazoyer - O. Casabonne (eds.), Antiquus oriens. Mélanges offerts au Professeur René Lebrun, Paris, 2004, I, p. 83-114: In an overview of the role played by religious cults in the representation of identity - in particular that of indigenous populations - in Hellenistic and Roman Asia Minor, B. discusses the complex methodological problems involved in the interpretation of the literary and epigraphic sources, focusing on the 'confession inscriptions', the problematic concept of the 'temple states' [on this subject see EAD., "Centri religiosi e territori nell'Anatolia ellenistica", in C. BEARZOT et al. (eds.), Gli stati territoriali nel mondo antico, Milano, 2003, p. 253-269 ], complex processes of syncretism and assimilation as revealed by cult epithets (e.g., Zeus Bronton), and the cult of Mes. [AC]

28) E. BOrgIA - M.H. SAYAR, "Le iscrizioni”, in E. EQUINI SCHNEIDER, Elaiussa Sebaste II, Rome, 2003, p. 525-540 [SEG LIII 1735-1736]: Ed. pr. of two altars dedicated to unknown divinities (535-537 nos 6-7, Elaioussa Sebaste, Imperial period). [The second text, dedicated by the trierarchos and crew of the ship Homonoia, seems to be dedicated to Zeus followed

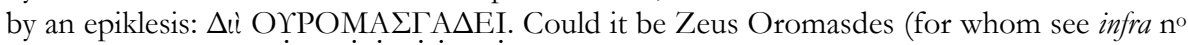
56)?]. [AC]

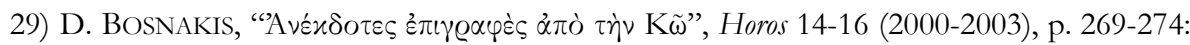
Ed. pr. of three inscriptions from Kos: a dedication by a paidonomos to Zeus Alseios and Athena Alseia for the health and orderly conduct of the boys (i $\pi \dot{\varepsilon} \varrho \tau \tilde{\alpha} \varsigma \tau \tilde{\omega} \nu \pi \alpha i \delta \omega \nu$ i $\gamma \varepsilon i \alpha \varsigma$

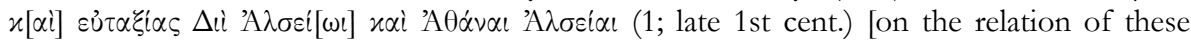
gods to education and the gymnasium in Kos see EBGR 1993/94, 219 and 1995, 143]; a grave boundary stone (2, 1st cent. AD) [cf. EBGR 1999, 18]; and a funerary altar for a purple-dyer (3, Imperial period). [JM]

30) A. BREsson, "Dédicaces de Lindos et de Rhodes pour Titus Flavius Aglôchartos", in L'bellénisme d'époque romaine, p. 225-232: An important monument from Lindos (SEG XL 668, 80-90 AD) records the erection of an honorific statue for Titus Flavius Aglochartos, priest of Athana Lindia and Zeus Polieus, and theoros to the agon of the Sebasta in Neapolis. According to B., another inscription from Rhodos (G. PUgliese Carratelli, "Per la storia delle associazioni in Rodi antica", $A S A A$ NS 1/2 [1942], p. 154f. no 14, c. 8090 AD) that honours a priest of Athana Lindia, Zeus Polieus, and Artemis Kekoia may refer to the same person. [JM]

31) A. BRESSON - P. BRUN - E. VARINLIOGLU, "Les inscriptions grecques et latines", in P. Debord - E. Varinlioglu (eds.), Les Hautes Terres de Carie, Bordeaux, 2001, p. 81-305 [SEG LI 1486-1487, 1497-1501, 1532-1559, 1562-1567]: This corpus assembles inscriptions found in southern Karia. [Many of these texts are also mentioned in EBGR 1991, 21 and 28; we do not mention texts found in other areas (e.g., Panamara); for the honorary decree for the priest Leon (84 and 89) see infra no 291]. Pisye: Dedications and cults: A dedication was made by a priest of Zeus Labraundos after his term of office (25). A man made a thanks- 


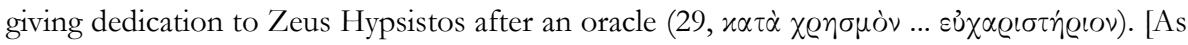

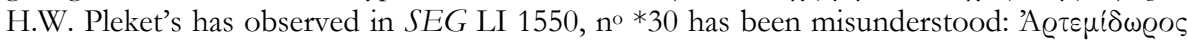

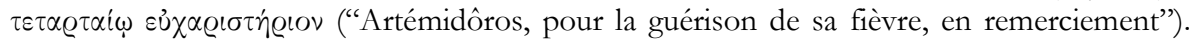
This is not a dedication to Asklepios, but to Tetartaios (sc. Pyretos), the personification of fever who was worshipped as a god. His cult is known in Samos (IG XII.6, $536=$ SEG XLVI 1174, 2nd cent. AD); it was probably introduced by the Romans ( $c f$. Quartana); $c$. SEG XXXIX 1503 (Theos Pyretos)]. Two altars attest the cults of Zeus Atabyrios (*26, 1 st/2nd cent.) and (Zeus?) Hypsistos (*28, Imperial period); a plaque with tabula ansata [probably a revetment plaque of an altar] mentions Sabazios (*27, Imperial period: $\Sigma \alpha \beta \alpha \dot{\sigma} \sigma o v)$. Funerary cult: Public burial of individuals ( $\left.\varepsilon^{\prime} \theta \alpha \psi \varepsilon \nu \delta \eta \mu \sigma \sigma i \alpha \tau \alpha \varphi \tilde{n}\right)$ is attested here $(* 3,4, * 5,2$ nd -1 st cent.) and in other communities (Tinaz: 31; Leukoideis: *37; Koloneis: $* 42$ ). Dedications (of statues) were made by individuals $(7,9-10, * 11-15, * 17-21, * 23)$ and the community (6) 'for' (íré@) other persons, often family members $(10-13,15,17,18,20$, 3 rd-1st cent.). In a few cases the posthumous character of the dedication is evident

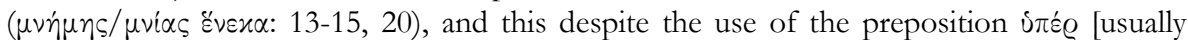
applied in dedications for the well-being of a person]. These formulae are also attested in other communities in this region (Tinaz: 31, 32?, *33-34; Leukoideis: *37; Koloneis: *41-46; Ula: 67; Idyma: 78). Several of these dedications were explicitly addressed to the gods $(7,9$, 17, 20, *44-45: $\theta \varepsilon$ ii s). [Two dedications were made by individuals for Rhodians whom they designate as their rescuers and benefactors. One observes influence from the vocabulary of

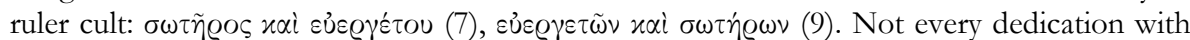
the $\dot{i} \pi \varepsilon \dot{\varrho}$ formula is funerary; see infra]. The deceased person is called a heros in no *16. Tinaz: On funerary dedications with íré decree for a Rhodian (*36, early 1st cent. BC) mentions his crowning during the festival of the Marollia (line 24: $\dot{\varepsilon} v \tau \tilde{\eta} \sigma u[v o ́] \delta \omega \iota[\tau] \tilde{\omega} \nu \mathrm{M} \alpha \varrho \omega \lambda \lambda \iota \omega \nu$ ) [or during the assembly of the Marollioi (an ethnic)]. The stele was to be set up in the sanctuary of Zeus Hypatos (line 22), whose cult is attested in Karia. The sanctuary received a fine if the annual crowning of the benefactor was neglected (line 31). The decree is dated with a reference to an eponymous priest (line 1; the Rhodian priest of Helios) and attests the month Badromios (line 1). A dedication for the well-being (?; 'en faveur', íréo) of a Rhodian to the gods is not necessarily funerary in the same way as similar dedications which apply this formula (see supra ad Pisye). The man had served as a priest (of Zeus Hypatos?), neokoros, and oinotamias (responsible for the purchase of wine for celebrations?; *38, 1st cent. BC/AD). Londeis: A fountain and a Nymphaion were constructed by two hierotamiai and dedicated to Zeus Karios and the Londais; the mention of 'sacred treasurers' shows that the revenues ( $\ddot{\pi} \pi \dot{\partial} \tau \tilde{\omega} \nu \pi \varrho \circ \sigma o \delta \delta \omega \nu$ ) used were those of the sanctuary of Zeus Karios (*39, late 2nd cent. BC). Koloneis: On funerary dedications with i $\pi \varepsilon \dot{\varrho}$ see supra (Pisye). Thera: Antimachos made a dedication to Asklepios of Epidauros in fulfilment of a vow (53, late 4th cent.; A A $x \lambda \eta \pi i \tilde{\omega} t \tau \tilde{\omega} \iota$ है 'E $\left.\pi \iota \delta \alpha \dot{v} \varrho \omega \iota \varepsilon \dot{x} \chi \eta^{\prime} \nu\right)$. The father and other relatives of Phanias, a Rhodian, who fought in a war, dedicated his statue to the gods $(* 56,1$ st cent.). A dedication to the gods was made for the well-being ( $(\dot{v} \tilde{\varepsilon} \varrho)$ of a Rhodian general (58, early 1 st cent. AD). Tarmianoi: Dedications were made to the gods for the well-being (ícé@) of Rhodian officials (62-63, 1st cent.). Former ephebarchai and gymnasiarchoi address their dedications to the gods of the gymnasion, Hermes and Herakles (64-65, 2nd-1st cent.; no 65 includes also Helios ). Ula: For funerary dedications with i $\pi \varepsilon$ @ see supra (Pisye) [on the Tarmianoi and the possible location of the community see R. VAN BREMEN, "Laodikeia in Karia", Chiron 34 (2004), p. 382-391]. Idyma: Dedications were made to the gods for the well-being (íré@) of Rhodian officials (70-71, 1st), the emperor Domitian (72) [this is not a "dédicace à Domitien"], and benefactors (73-74, 1st cent. BC/AD). Lists of priests of Leto and Aphrodite are preserved in two fragments $(75-76,2$ nd $/ 1$ st cent.). For funerary dedications 
with $\dot{\pi} \varepsilon$ é see supra (Pisye). Kallipolis: A statue of Domitia was dedicated to the gods (85) [not a "dédicace à Domitia"]. A fragmentary text [not a "dédicace à un Antiochéen"] mentions the cult association of worshippers of Helios [founded by a Polemakles] under the

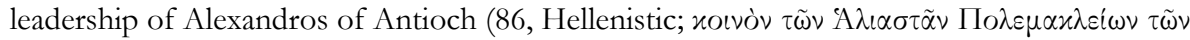

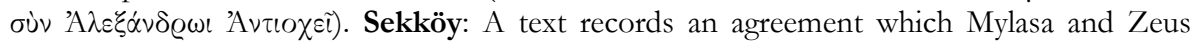
Osogollis concluded with the Kindyeis concerning the purchase and demarcation of sacred land $(90,354 / 3 \mathrm{BC})$; the transaction took place in the presence of representatives of other Karian communities. Representatives of Karian communities are also listed in a contemporary document of unknown content but similar character (91). [As we pointed out in EBGR 1990, 32, the presence of representatives of the Karian communities as witnesses in these transactions implies that the sanctuary of Zeus Osogollis, for which the land was purchased, was the religious centre of a (the?) Karian Koinon]. An interesting honorary decree of the demos of the [---]reis for two administrators (epitropor) praises them for their zeal in successfully procuring money in connection with customary sacrifices and rituals $(* 92 \mathrm{~B}, 2 \mathrm{nd}$ cent.). [Пв@i $\sigma \tau \alpha \sigma \iota \varsigma$ ('difficult situation') in line 7 shows that the community was facing a

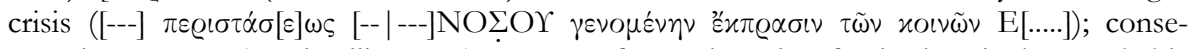

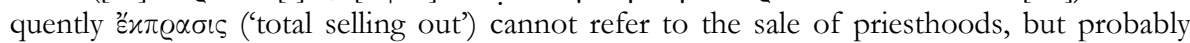

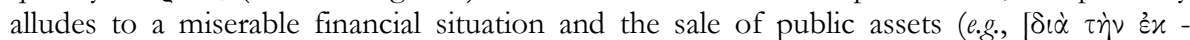

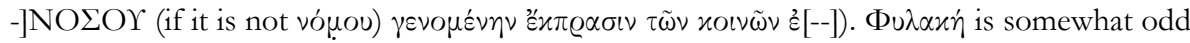
in lines 5f. (

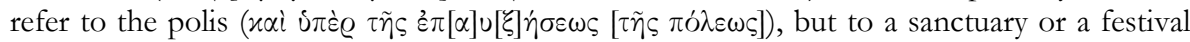
since the text clearly refers to religious matters ( $c f$. line 16: $\tau \varepsilon \mu \mu \dot{\alpha} \varsigma \tau \tilde{\omega} \nu \quad \theta \varepsilon \tilde{\omega} \nu)$; the desire to augment festivals, rituals, and sanctuaries ( $\alpha \dot{\zeta} \xi \dot{\alpha} \nu \varepsilon \iota v, \sigma u v \alpha u \xi \dot{\alpha} v \varepsilon เ v)$ is often mentioned in Hellenistic documents (e.g., EB p. 229f.)]. In an appendix the eds. publish a new dedication to the Eleusinian Goddesses by Ti. Flavius Phaidros, who voluntarily served as priest during the celebration of the Heraia, and his wife Fl. Aristolais (Appendix 1, Panamara, c. 160-

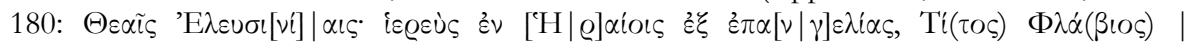

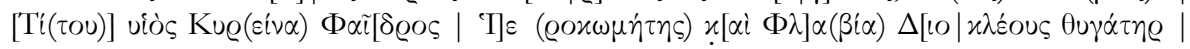

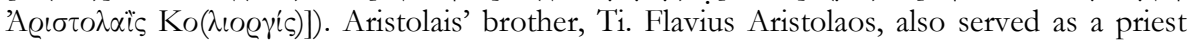

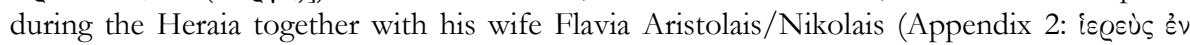

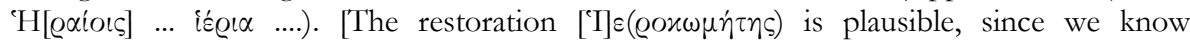
Phaidros' demotic from other texts; but it is possible that at this point the text mentions his

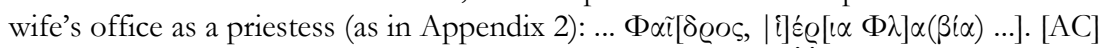

32) A. Brugnone, "Riti di purificazione a Selinunte", Kokalos 45 (1999) [2003], p. 11-26 [SEG LIII 1032]: B. summarizes the information provided by the sacred law from Selinous concerning purifications [cf. infra $\mathrm{n}^{\text {os }} 69$ and 74], focusing in particular on family cults (cf. IG XII.3, 377-378, 1316-1318; LSCG Suppl. 115 A lines 21-25). She suggests interpreting the

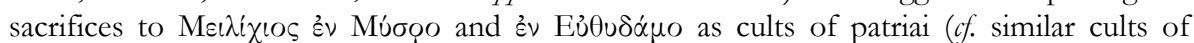
kinship groups in IG XII.3, 1316; XII.5.1027; I.Lindos 899-907). [A shorter version of the same article appeared in Sicilia Archeologica 30 (1997), p. 121-131]. [AC]

33) S.L. Budin, "Pallakai, Prostitutes, and Prophetesses", CPh 98 (2003), p. 148-159: Two dedications to Zeus in Tralleis (2nd/3rd cent.) were made by women who had served as

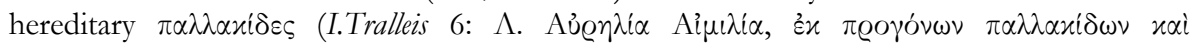

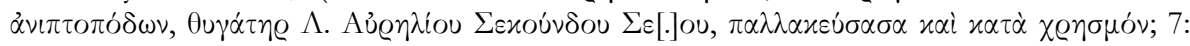

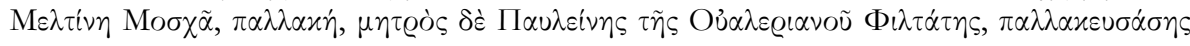

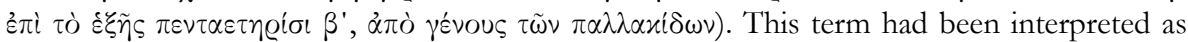
evidence for sacred prostitution practiced during a pentaeteric festival of Zeus (L. ROBERT, Études anatoliennes, Paris, 1937, p. 406f.) or as evidence for a form of divination that incorporated perceived sexual relations with a god (K. LATTE, "The Coming of the Pythia", 


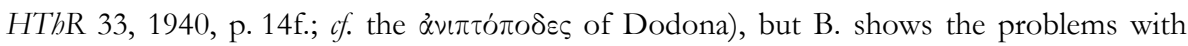
both interpretations. After briefly considering the possibility that $\pi \alpha \lambda \lambda \alpha x \dot{\eta}$ has its normal meaning ('concubine'), supporting this assumption with the [wrong] observation that one of the two pallakides used a metronymic because she was an illegitimate daughter of a concubine, B. rightly favors the interpretation of $\pi \alpha \lambda \lambda \alpha x \dot{\eta}$ as cult functionary. The reference to a woman serving as a pallake in two consecutive pentaeterides, the use of the participle $\pi \alpha \lambda \lambda \alpha \varkappa \varepsilon \dot{\sigma} \sigma \alpha \sigma \alpha$, which implies a functionary leaving office, and the hereditary character of the function leave little doubt that the pallakai were functionaries in the cult of Zeus. They may have been responsible for the daily maintenance of Zeus, his statue, and his sanctuary, or, if pallake is used as the female equivalent of pallax (male youth), they may have been considered to be the maidens or daughters of Zeus. B. speculates that the word may be related to $\pi \dot{\alpha} \lambda \lambda \omega$ ('to brandish', i.e., spear-brandishers; $c f$. Pallas). [The reference to pentaeterides suggests that these women exercised this function during a festival and not on a daily basis. Unfortunately, this interesting article is full of mistakes regarding onomastic formulae. The use of the nomen Seius (only restored in I.Tralleis 6 and very common in the East) is taken as an indication of Etruscan origin; the restoration of this name is improbable since it is restored in a position where one does not expect a nomen gentile but a second name (L. Aurelius

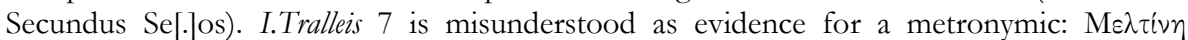

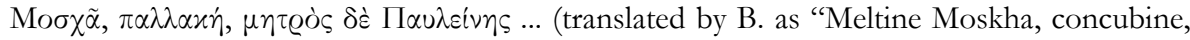

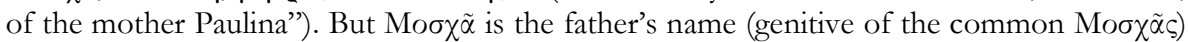
and the use of $\delta \dot{\varepsilon}$ shows that both parents were named ("Meltine, daughter of Moschas, a pallake, whose mother was Paulina"). The remark that "both Aurelia and Meltine use their family names (Seius, Valerianus)" is completely wrong. The one woman (not Aurelia, but Aimilia) did not use the family name Seius but the Roman nomina as a Roman citizen and a daughter of a L. Aurelius Secundus; Valerianus is not a family name (it is a cognomen) and it was not used by Meltine; it is the patronymic of Meltine's mother]. [AC]

34) K. Buraselis, "Zur Asylie als außenpolitischem Instrument in der hellenistischen Welt", in $A s y l$, p. 143-160: B. stresses the political and diplomatic significance of the recognition of the inviolability of sanctuaries in the Hellenistic period [cf. EBGR 1996, 229]. He discusses in detail the political relations between Seleukos II and Smyrna which may explain his support for the asylia of the sanctuary of Aphrodite Stratonikis. The primary motive of Tenos, Anaphe, Magnesia on the Maeander, Teos, and Alabanda for seeking the recognition of the asylia of their sanctuaries was their protection from raids, in particular those of Cretan pirates [cf. infra no 36]. JJM]

35) K. Buraselis, "Political Gods and Heroes or the Hierarchisation of Political Divinity in the Hellenistic World", in A BARZANÒ et al. (eds.), Modelli eroici dall'antichità alla cultura europea, Rome, 2003, p. 185-197: The literary and epigraphic evidence for the cult of mortals of nonroyal status (Hephaistion heros: EBGR 1990, 317; Philetairos in Kyme: EBGR 2000, 126; Boethos in Egypt; Aratos in Sikyon) shows the existence, alongside the isotheoi timai for Hellenistic kings, of a hierarchically lower-ranking level of worship of mortals (e.g., the heroic cult of Aratos in Sikyon). In Kyme, e.g., Antiochos I was honoured in a festival

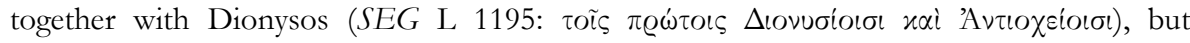

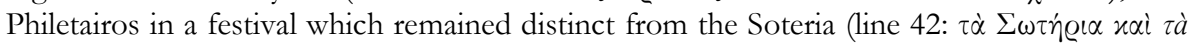
$\Phi i \lambda \varepsilon \tau \alpha i \varrho \varepsilon[l] \alpha)$. The cult of Philopoimen in Megalopolis (Syll. ${ }^{3}$ 624) was based on the model of the hero cult but through its association with the cult of Zeus Soter and Hestia it was inserted among the divine cults of the city. The model of deification was preferred to that of heroisation in the case of a few non-royal benefactors (Diodoros Pasparos, Artemidoros, and Theophanes) [cf. infra $\mathrm{n}^{\circ}$ 265]. The heroisation of a living person (Nikias in Kos, 
symbolically affiliated to the deified Koan Demos) was a rare phenomenon [on Diodoros Pasparos of. supra no 5 and infra no 265]. [AC]

36) K. Buraselis, "Some Remarks on the Koan asylia (242 B.C.) against its International Background", in The Hellenistic Polis of Kos, p. 15-20: The ambitious campaign of the Koans around $242 \mathrm{BC}$ to achieve the general recognition of the inviolability of their most important sanctuary, the Asklepieion, and the panhellenic character of the pentaeteric festival of the Asklepieia is well documented through a large number of relevant inscriptions and is normally seen in a purely religious context (EBGR 1996, 229). B. convincingly adds an important political aspect: by the mid-3rd cent. the Koans could no longer rely exclusively on the Ptolemies for adequate protection. Thus, religious motifs were prudently exploited in order to achieve the asylia of the Asklepieion and thus that of the entire island [cf. supra no 34 and infra no 108]. JJM]

37) P. CABANES, "Recherches sur le calendier corinthien en Épire et dans les régions voisines", REA 105 (2003), p. 83-102: C. collects the month names attested in Epidamnos, Apollonia, Korkyra, Bouthrotos, the Koinon of the Balaitai, Dodona, Ambrakia, Charadros, Gitane, Kerkyra Melaina, and Syracuse. This evidence supports the assumption that these cities had adopted the Corinthian calendar, for which C. proposes the following sequence of

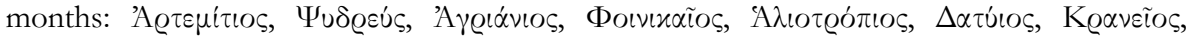

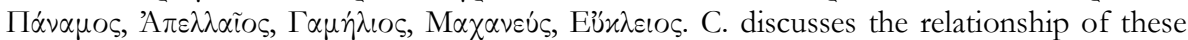
month names to cults and festivals (Agranios is probably connected with Dionysos and the A $\gamma \varrho \iota \dot{\omega} v \iota \alpha$; Apellaios with Apollon; Artemitios with Artemis; Datyios possibly with the Macedonian Daisios; Gamelios with Hera; Eukleios with Artemis or Zeus; Kraneios/ Karneios with Apollon; Machaneus with Zeus or Athena; Phoinikaios perhaps with Athena; Psydreus perhaps with Hermes). [AC]

38) É. CAIRON, "Épigrammes funéraires d'Argos à l'époque hellénistique", in L'hellénisme d'époque romaine, p. 77-84: C. studies the four known Hellenistic metric funerary inscriptions from the Argolid (IG IV 623+624; SEG XI 343; GV 618, 1791) and shows that the texts do not contain any references to afterlife, revealing instead a close connection to the relevant inscriptions of the Classical period as regards topics and vocabulary. [JM]

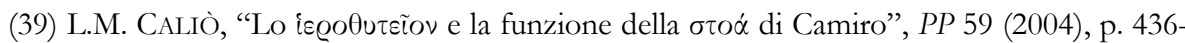
459: A Roman sacred law from Kamiros mentions a bierothyteion on the acropolis (LSCG Suppl. 105). Several inscriptions from Lindos (e.g. IG XII.1, 846-849, 853) and an inscription from Kamiros (Tit.Cam. 86) specify the function of such a building. Apparently, the hierothyteion was used in the organisation of public meals, after sacrificial rituals. According to C., the bierothyteion should be located in the sanctuary of Athena Kamiras or Polias and Zeus Polieus. Together with a Hellenistic stoa, the hierothyteion created a building complex where public meals were served during festivals honouring the poliadic deities. The author presents an intriguing reconstruction of the religious topography of the sanctuary, which occupied three terraces with their respective religious focal points: the lower terrace with an altar, the middle terrace with the bierothyteion and the stoa, and the upper terrace with the temple (and the altar) of Athena and Zeus. [JM]

40) D. CAMPANILE, “Asiarchi e archiereis d'Asia: Titolatura, condizione giuridica e posizione sociale dei supremi dignitari del culto imperiale", in Les cultes locaux, p. 69-79: Based on the epigraphic evidence (e.g. I.Ephesos 1487-1488), but mainly on literary sources (e.g., Strabo, Aelius Aristeides, and Cassius Dio) C. rejects the assumption that the titles asiarches and archiereus of Asia designated two different offices. Asiarches may originally have been the title of the chairman of the Koinon Asias before 29 BC [cf. infra nos 41 and 220]. [JM] 
41) M. CARTER, “Archiereis and Asiarchs: A Gladiatorial Perspective”, GRBS 44 (2004), p. 41-68 [BE 2004, 256]: C. returns to the much debated question of whether the titles archiereus and asiarches designated two distinct offices [EBGR 1999, 79; supra no 40 and infra $\left.n^{\circ} 220\right]$ or were two different names for the same position [EBGR 2000, 56; 2002, 156], exploiting the evidence for gladiatorial spectacles offered by high priests and Asiarchs. From the 25 inscriptions referring to gladiatorial familiae in Asia Minor, nine (SEG XLVI 1657; IGR IV 103, 175, 617; I.Laodikeia 73, 1015; L. ROBERT, Les gladiateurs dans l'Orient grec, Limoges, 1940, nos 156-157; C. Roueché, Performers and Partisans at Aphrodisias, London, 1993, no 13) identify the owner as an archiereus and another nine (IGR IV 156, 1075; I.Smyrna 842; SEG XLII 1036; I.Ephesos 1171, 1182, 1620, 1621, 4346) as an asiarches. Several inscriptions reveal that the presentation (and funding) of spectacles was a very important activity of a high priest (e.g. I.Stratonikeia 701), while the sponsorship of expensive spectacles (gladiatorial games and wild beast hunts) is attested for asiarchai, too (e.g. I.Ephesos 3070; I.Smyrna 637). C. concludes that gladiatorial combats and similar spectacles were presented under the archierosyne, while the title asiarches was used, at least in the gladiatorial context, as an informal equivalent of the title archiereus. It seems that by the 2 nd cent. AD the presentation of such spectacles was explicitly expected from officials of the Imperial cult. [JM]

42) J.-B. CAYLA, "Livie, Aphrodite et une famille de prêtres du culte impérial à Paphos", in L'hellénisme d'époque romaine, p. 233-243: C. discusses briefly a fragmentary inscription with Greek and Latin texts from the sanctuary of Aphrodite at Paphos (IGR III 948, 963, 1st cent. AD). The author demonstrates that this is not a bilingual inscription, since the two texts have nothing to do with each other, neither thematically nor chronologically. The Greek inscription is convincingly restored as a dedication to Iulia Sebaste Nea Aphrodite by an archiereia, whose name is not preserved on the stone. Interestingly, all the known persons involved in the Imperial cult at Paphos in this period seem to belong to the same family. In an appendix C. assembles the Greek inscriptions that attest the activities of the Koinon ton Kyprion in connection with the emperor cult. [JM]

43) A. Chaniotis, "New Inscriptions from Aphrodisias (1995-2001)", AJA 108 (2004), p. 377-416 [BE 2005, 422]: Ed. pr. of 29 inscriptions from Aphrodisias. A posthumous honorary decree for the benefactor Hermogenes (1, c. 50 BC) praises him for his piety (line

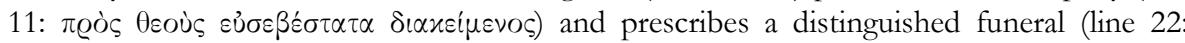

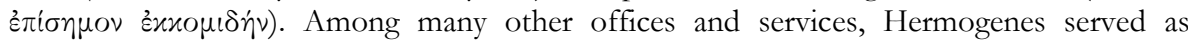

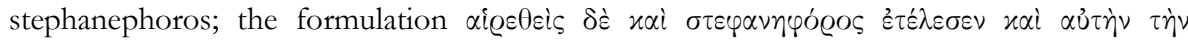

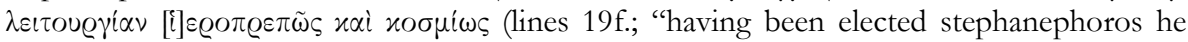
fulfilled this liturgy too in the manner appropriate to a religious office and with decency") is a clear indication of the cultic origins of this magistracy. A base supported a statue of Thea Eleutheria, whose cult was already known in Aphrodisias (8, 1st-2nd cent.). A bronze-smith, possibly a slave, dedicated the statuette of an eagle to Zeus Nineudios in fulfilment of a vow (11, 1st cent. BC). The cult of Zeus Nineudios was one of the major cults at Aphrodisias.

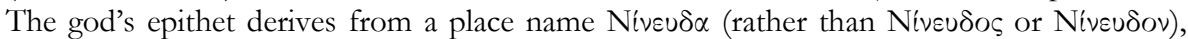
probably the earlier name of Aphrodisias. A building inscription commemorated the construction of the North Agora at the expenses of C. Iulius Zoilos, a freedman of Octavian, stephanephoros and priest of Aphrodite and Eleutheria for life (12, late 1st cent.). An inscribed cornice records the dedication of a building to Thea Aphrodite (?, 13). Another building was dedicated to Hephaistos by his priest (15, 2nd cent. AD). Several epitaphs have

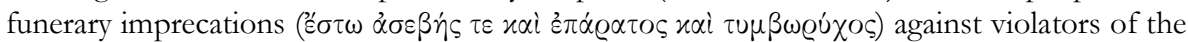
tomb $(23,26,27,29 ; 2$ nd/3rd cent.). [JM] 
44) A. Chaniotis, "Under the Watchful Eyes of the Gods: Divine Justice in Hellenistic and Roman Asia Minor", in The Greco-Roman East, p. 1-43 [BE 2005, 416]: The principal topic of this study is the complex nature of the intervention of religious authorities in judicial matters and legal disputes. C. focuses on Asia Minor and uses as his main source the 'confession' or 'propitiatory inscriptions' from Lydia and Phrygia [cf. EBGR 1994/95, 285; 2002, 129 with further references], but stresses their conceptual affinity to related evidence, such as the curse tablets from the Knidian sanctuary of Demeter (I.Knidos 147-159, 2nd/1st cent.), vows addressed to gods requesting support in financial and legal matters (e.g., SEG XLI 1012), epitaphs referring to a crime or requesting the punishment of those who may have wronged the deceased person (e.g., SEG XLIV 1050, early 3rd cent. AD), and 'prayers for justice' attesting the cession of lost or disputed property to gods. As H.S. VERSNEL has shown [infra $\left.n^{\circ} 294\right]$, people defended themselves with exculpatory oaths, curses, and confession inscriptions because of public pressure, and not because of the pressure imposed on them by priests (e.g., BIWK 69, AD 156/7). In BIWK 6, Artemidoros defended himself against slander and delivered to the sanctuary of Men Axiottenos a tablet ( $\pi \iota \tau \tau \dot{\alpha} \varkappa \iota \mathrm{ov}$ ' $\delta \omega \varkappa \varepsilon v)$, not a curse tablet, but a 'prayer for justice'. C. suggests that the background of several confession inscriptions (e.g., BIWK 18, AD 199/200) was the handing over of disputed object(s) to the god and consequently to the temple. Unlike the depositing of defixiones, the erection of a confession inscription was a public performance. The priest was the appropriate authority to perform the curse ceremony, usually by setting up the symbol of the god, a sceptre (e.g.,

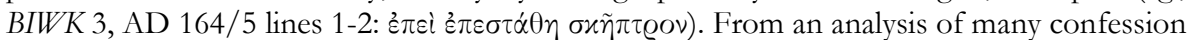
inscriptions $C$. reconstructs the role played by priests in the implementation and presentation of divine justice: they assisted people who thought that were being punished by the gods to identify the causes of divine anger; they did not inflict additional punishment (e.g., $B I W K$ 98, 2nd cent. AD) but prescribed rituals of atonement and demanded remuneration of the temples for their services in resolving the problem. C. convincingly rejects the assumption that priests functioned as judges when conflicting parties came to the sanctuary to solve their dispute. In this context C. offers a new interpretation of BIWK 33 (3rd cent.

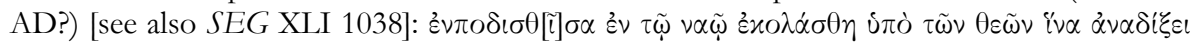
$\tau \dot{\alpha} \varsigma \delta$ $\delta \dot{\alpha} \mu \iota \varsigma \alpha \dot{u} \tau \tilde{\omega} \nu$ ("she had been detained in the temple and for this reason she has been punished by the gods in order to reveal their powers" [and not: "she has been punished by the gods by imprisonment in the temple, so that their powers may be revealed"]. From honorary decrees for the priests Aristodemos (SEG XLV 1515, Hisartepe in Karia, 1st cent.) and Leon (SEG XLV 1556-1557, Panamara, 2nd cent.) he infers that priests arbitrated rather than judged in legal disputes and administrated exculpatory oaths [but see the more plausible interpretation of the relevant passages in the decrees for Leon by VAN BREMEN, infra no 291]. Several confession inscriptions refer to the annulment of false oaths (e.g., BIWK 34, 3rd cent.; BIWK 52, AD 119/120 or AD 173/4; BIWK 54, AD 118/9), a procedure which required fines payable to sanctuaries (BIWK 58, AD 166/7). C. concludes that sanctuaries (and their priests) were the keepers of a strict moral order, assuming the role of mediators in legal disputes. [On 'confession inscriptions' see also infra n ${ }^{\circ s} 45,98-99$, and C. BRIXHE, "Individu, langue et communauté sociale : à propos des confessions païennes du Moyen Hermos", in C. CONSANI - L. MuCCIANTE (eds.), Norma e variazione nel diasistema greco, Alessandria, 2001, p. 101-118 (non vidimus, see BE 2003, 463]. [JM]

45) A. CHAniotis, "Von Ehre, Schande und kleinen Verbrechen unter Nachbarn: Konfliktbewältigung und Götterjustiz in Gemeinden des antiken Anatolien”, in F.R. PFETSCH (ed.), Konflikt, Heidelberg, 2004 (Heidelberger Jabrbücher 48), p. 233-254: This study discusses a selection of 'confession inscriptions', prayers for justice, and dedications [cf. supra no 44] as evidence for everyday conflicts in small communities, for the appeal to the gods for justice, 
the role of the priests as arbitrators in the conflicts between humans and between humans and gods, the importance of honour and loss of face as causes of conflicts, and the public nature of the rites and performances referred to in these texts. [JM]

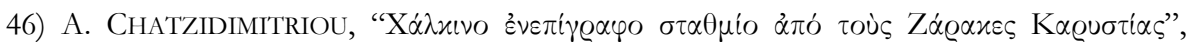
AEThSE 1 (2003) [2006], p. 1077-1092: A fragment of an Archaic pithos was found during excavations at Zarakes (Euboia). It bears the figures of centaurs in relief and the word iع@ós. Vase fragments with the incised letters $\iota$ (= iع@ós) were also found at the same spot. An inscribed bronze weight in the shape of the head of a ram (4th cent.) gives the name of the deity worshipped here (A $A \dot{0} \lambda \lambda \omega v o \varsigma \Delta \eta \lambda i o u)$. C. analyzes the mythological tradition of Zarakes (ancient Zarax) and demonstrates the close connections of this site with the cult of Apollon on Delos. [See already EBGR 2002, 25; SEG XLIX 1205; LI 1126-1128]. [JM]

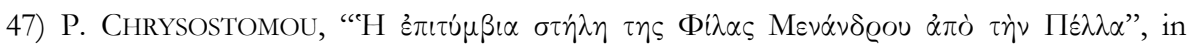

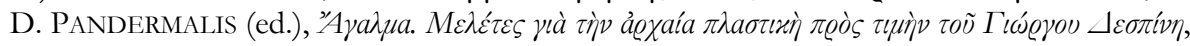
Thessalonike, 2001, p. 233-242: C. publishes the grave stele for Phila, daughter of Menandros (Pella, c. 350). Phila is represented in relief, standing; next to her a female servant carries a basket with sacrificial cakes. C. assumes that Phila was a priestess and suggests identifying her with Phila, the author of a well-known contemporary love curse tablet in Pella (SEG XLIII 434; EBGR 1998, 290). [AC]

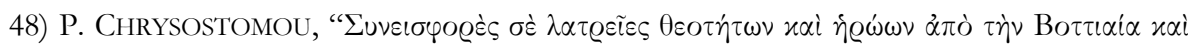

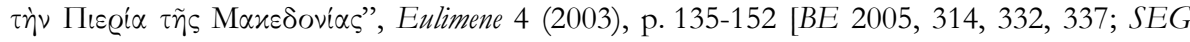
LIII 610, 619, 620]: 1) [Without knowledge of an earlier publication, as observed by M.B. Hatzopoulos, BE 2005, 337], C. republishes a dedication made by Nausimachos to the Muses (Pella, c. 350-300). The epithet $\pi 0 \lambda \iota \dot{\tau} \iota \_\varepsilon \varsigma$ attributed to the Muses in Pella in epigrams composed by queen Eurydike (Plut., mor. 14c) and Poseidippos (Supplementum Hellenisticum fr. 705) shows that a cult place of the Nymphs must have existed in the city, possibly in the theatre, in addition to the cult place near the find spot of this inscription (west of Pella). From the lack of a patronymic C. infers that the dedicant was a priest of the Muses or a

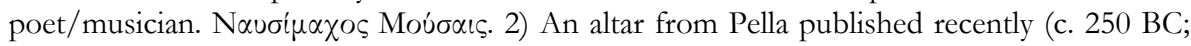
SEG L 611; EBGR 2001, 110] was an altar for Aiolos, father of Makedon, the eponymous hero of the Macedonians (Hellanikos, FgrHist 126 F 74), and the nymph Graie, his daughter

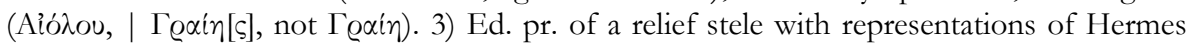
and Demeter (Kyrrhos, 2nd/3rd cent.); it was dedicated by Olympos and another person [his wife?] to Hermes and Demeter in accordance with a dream ( $\left.x \alpha \tau^{\prime}{ }^{\prime}[\nu \alpha \varrho]\right)$. The cult of Hermes was already attested in Kyrrhos; as a patron of fertility he was associated with Demeter. $[\mathrm{AC}]$

49) V. Consoli, "Atena Ergane. Sorgere di un culto sull' Acropoli di Atene, ASAA 82 (2004) [2006], p. 31-60: Only nine Athenian inscriptions of the 4th cent. attest the cult of Athena Ergane on the Athenian Acropolis (IG I2 561; II 2939, 4318, 4328, 4329, 4334, 4338, 4339; Agora I 1732). C. presents archaeological and epigraphic evidence in an attempt to reconstruct a cult of the goddess already existing in the late Archaic period. She associates the so-called kerameis-inscriptions $\left(I_{G} \mathrm{I}^{3} 620,628,633,824\right)$ from the late 6 th and early 5th cent. with an early cult of Athena Ergane, despite the fact that none of these inscriptions records the epiclesis [some of them do not even name Athena, since it is obvious who is the addressee of the dedication]. Despite the lack of factual evidence, C.'s assumption is probably correct, since other specialized forms of Athena also appeared as early as the 6th and early 5th cent. (e.g., Nike: IG I3 596, mid-6th cent.; Hygieia: C. WAGNER, "The Potters and Athena", in G. Tsetskhladze et al. [eds.], Periplous. To Sir John Boardman from His Pupils and Friends, London, 2000, p. 385, c. 470 BC). [JM] 
50) T. CORSTEN, “Kibyra 2000”, AST 19.2 (2001), p. 139-146 [SEG LII 1433-1434]: Ed. pr. of two dedications to Theoi Dikaioi from Kibyra. See already EBGR 2002, 28 (I.Kibyra 9596) [for another dedication to Theoi Dikaioi in Lykia see infra no 120]. [AC]

51) T. CORSTEN, "Kibyra 2001", AST 20.2 (2002), p. $83-84$ [SEG LIII 1674]: Ed. pr. of a rock-cut dedication to the Dioskouroi ( $\left.\varepsilon \dot{u} \chi \dot{\eta}^{\prime} \nu\right)$ written near a relief representation of these gods (Kibyra, Imperial period). [AC]

52) T. CORSTEN, "Kibyra 2003”, AST 22.1 (2004), p. 29-34 [BE 2006, 382]: The fragment

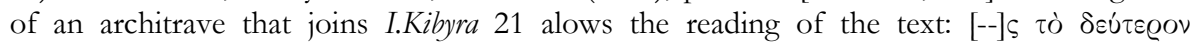

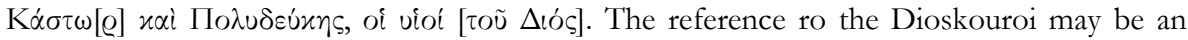
allusion to the foundation of Kibyra by Spartans. A second fragment of an architrave (late 2nd cent. AD.) refers to the otherwise unattested 'old' asylia of Kibyra (ż $\pi \dot{\alpha} \lambda \alpha \iota \dot{\alpha} \sigma \dot{\omega} \lambda \eta \varsigma$ ) [an allusion to cities that had only recently been awarded the asylia; for this competition among

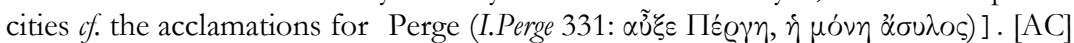

53) T. CORSTEN, “Zu Inschriften aus Kleinasien”, EA 37 (2004), p. 107-114 [BE 2005, 465]: An inscription within a tabula ansata at the entrance of a barely accessible cave near Anazarbos documents the dedication of Regina to Zeus, Hera Gamelia, and Ares

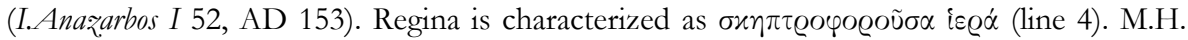
SAYAR [cf. EBGR 2000, 178] identified Regina as the eponymous priestess bearing the sceptre as a symbol of her power. C. demonstrates convincingly that Regina was not a

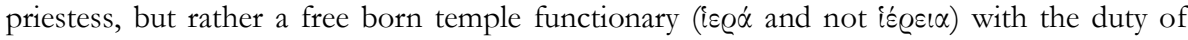

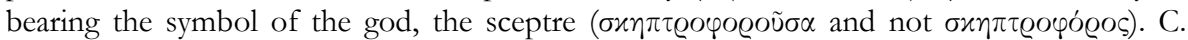
restores the first two lines of a dedication to Meter Andeirene by Eukarpos found at

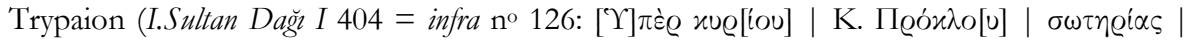

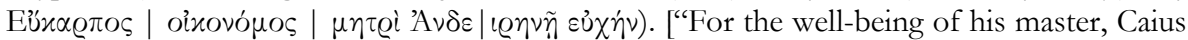
Proclus, the manager of his estate, Eukarpos, [dedicated this] to Meter Andeirene in fulfilment of a vow". A very similar restoration was proposed independently by M. RICL; see EBGR 2003, 142]. [JM]

54) F. CostabiLe, “Defixiones dal Kerameikos di Atene II”, MEP 4 (2000), p. 37-123 [SEG LI 66, 327-328]: C. presents a revised edition of the defixiones which are discussed in our next lemma. In addition to these texts he discusses, in general, judiciary defixiones in Athens. In this context he republishes the curse tablets already presented in EBGR 1999, 42 [the readings have been rejected by D.R. JORDAN; see infra $\mathrm{n}^{\circ}$ 127]. [AC]

55) F. Costabile, "La triplice defixio: nuova lettura", MEP 6 (2001), p. 143-208: C. presents a third critical edition and Italian translation of the defixiones from Kerameikos (c. 390-375?) [cf. supra $\mathrm{n}^{\circ} 54$ and infra $\mathrm{n}^{\circ}$ 131]. The main differences from his second edition are

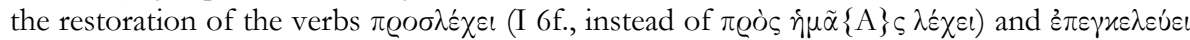

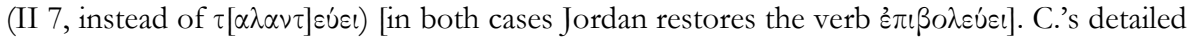
commentary concerns the letterforms, the prosopography (identification of Smindyrides with a man involved in the profanation of the mysteries in $415 \mathrm{BC}$ ) and the legal context (the jurisdiction of the polemarchos in lawsuits concerning foreigners). In this context C. republishes another judicial defixio from Athens (DT 49). [AC]

56) L. Criscuolo, "Agoni e politica alla corte di Alessandria. Reflessioni su alcuni epigrammi di Posidippo”, Chiron 33 (2003), p. 311-333: C. discusses a series of epigrams of Poseidippos referring to victories in equestrian competitions of members of the royal house of the Ptolemies (Berenike I, Ptolemy I and II, Arsinoe II) and of the Ptolemaic court (Etearchos, Kallikrates, Philitas, Sostratos) in agones in Delos (Ptolemaia), Olympia, Isthmos, Delphi, Nemea, and Argos (ep. 36-39, 63, 74, 76, 78-82, 87-88, 115-116, 119 ed. 
Austin-Bastianini). A study of these epigrams against the epigraphic evidence shows that the presence of the first Ptolemies in great Greek sanctuaries served their diplomatic purposes. C. favours the identification of Berenike, mentioned in some of these epigrams, with the daughter of Ptolemy II (not with Berenike II). [AC]

57) C. Crowther - M. Facella, "New Evidence for the Ruler Cult of Antiochus of Commagene from Zeugma", in Religionsgeschichte Kleinasiens, p. 41-80 [BE 2005, 507; SEG LIII 1762, 1764, 1766, 1768-1773]: This important study presents two new inscriptions concerning the ruler cult of Antiochos I of Kommagene; they were found during rescue excavations at Zeugma in 2000. Since neither of them was found in situ, it is possible only to offer hypotheses about the original location of the temenos where they stood. Although there is no secure evidence for the location of the temenos at Zeugma, C.-F. suggest that it should be located somewhere near the find spot of the basalt inscription. (1) The better preserved text is inscribed on a sculptured basalt stele depicting a dexiosis scene (see also infra no 215). It corresponds exactly to known inscriptions found in Samosata (OGIS 404) and Doliche (SEG XXXII 1385); because of its good preservation it allows a number of restorations and corrections to the aforementioned inscriptions. Lines 4-6 stress the fact that relief image and text were considered by Antiochos as a unity that expressed in two

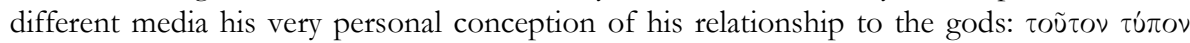

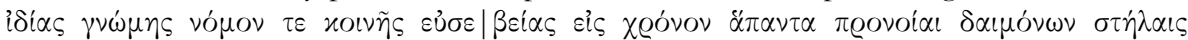

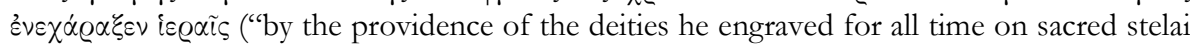
this depiction of his own thought and law of common piety"). In lines 14-17 Antiochos states that he founded the new temenos dedicated to Zeus Oromasdes, Apollon Mithras

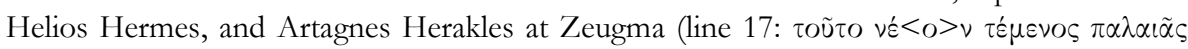
$\delta \cup \vee \alpha \dot{\mu} \mu \omega \varsigma$ है $x \tau \iota \sigma \alpha)$ immediately after he had succeeded to his ancestral kingdom (lines 14-15:

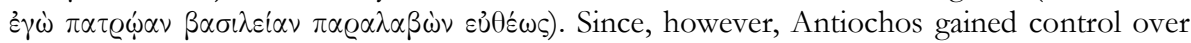
Zeugma only after 64 BC, C.-F. plausibly suspect that this part of the Zeugma inscription was originally conceived for a different situation (for a temenos which was indeed founded immediately after Antiochos succeeded to his kingdom) and also adopted by the scribe for the version in Zeugma. An interesting feature is that an erased text underlies the inscription; it corresponds to the text preserved on a basalt stele in the temenos at Sofraz Köy (SEG XXXIII 1215) and on a stele of unknown provenance now in the Adiyaman Museum. It is striking that the inscription at Sofraz Köy states that the sanctuary was dedicated to purely Greek deities: Apollon Epekoos and Artemis Diktynna (lines 6-7). Yet, since the erased inscription of Zeugma was written after $64 \mathrm{BC}$, it must have contained a dedication to Zeus Oromasdes, Apollon Mithras Helios Hermes, and Artagnes Herakles (2). The smaller inscribed fragment was engraved on a limestone block. It is part of a sacred law known from a document from Selik-Samosata (SEG XII 554). The preserved text refers to the duties of the priests and the sacred slaves. In a very helpful appendix (p. 68-77) C.-F. republish some of the related texts - with some revisions - from Samosata, Doliche, Sofraz Köy, Adiyaman Museum, and Çaputlu Ağaç Küllük [cf. P.F. MiтTAG, “Zur Selbstdarstellung Antiochos' I. von Kommagene", Gephyra 1 (2004), p. 1-26; M. FACELLA, La dinastia degli Orontidi nella Commagene ellenistico-romana, Pisa, 2006]. [JM]

58) E. CSAPO - A.W. JOHNSTON - D. GEAGAN, "The Iron Age Inscriptions", in J. SHAW M. SHAW (eds.), Kommos. Vol. IV. The Greek Sanctuary, Princeton, 2000, p. 101-134 [SEG LIII 953-954, 957]: Corpus of the inscriptions, primarily graffiti, found in the great sanctuary at Kommos on Crete; most of the texts are inedita. They include a dedication to Poseidon (75, 2nd cent. BC; mentioned in preliminary reports as a dedication to Apollon; see $B E 1982,274)$. Another dedication is addressed to Zeus, Euangelos, and Athena (76,

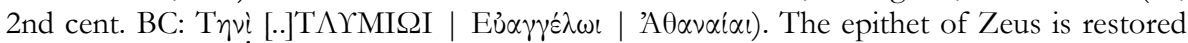


as a form of Phytalmios, an epithet attested for Poseidon; Euangelos seems to be a separate divinity, rather than en epithet of Athena [euangelios (the one who brings good news) is an epithet of the Dioskouroi and Meter (infra $\mathrm{n}^{\circ}$ 138)]. Two very fragmentary graffiti (10-11, 7th cent. BC) possibly name Apollon. [AC]

59) J. CurberA, “Onomastic Notes on IG XII 6 (Samos)", Glotta 80 (2004), p. 1-13 [BE 2006, 147]: In a study of names attested in the inscriptions of Samos, C. discusses inter alia theophoric names. The most common among them are those connected with Zeus (145 cases), Apollon (122), Dionysos (80), Demeter (69), Artemis (50), and Hermes (43), followed by those connected with Athena (34), Meter (34), Mes (30), and Poseidon (19); names alluding to Hera are not very common (45), but names composed with $\theta \varepsilon o ́ \varsigma$ (65) may

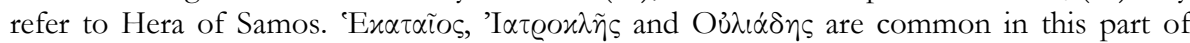
Ionia. Theophoric names alluding to Hephaistos and the Nymphs are rare. C. regards Basileides as related to Theos Basileus rather than to Hera Basileios [but the patronymic ending -eides is unusual for theophoric names]. $\Upsilon \beta \lambda \dot{n} \sigma \iota \varsigma$ (from an epithet deriving from a

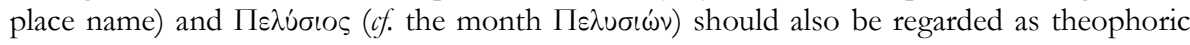
names. $[\mathrm{AC}]$

60) L.I. Davydova - S.R. TokHTAS'Ev, "Posvjatitel'n'ij rel'ef Gerakly iz Kollekcii Zrmitaža", in Anacharsis, p. 88-89 [SEG LIII 808 ter]: Edition of an inscribed relief representing Herakles (South Ukraine or Russia; 1st/2nd cent.; $\tau \grave{o}\langle\gamma\rangle{ }^{~}{ }^{H} \mathrm{~L} \alpha x \lambda \tilde{\eta} \nu \mathrm{v}$ ) [rather

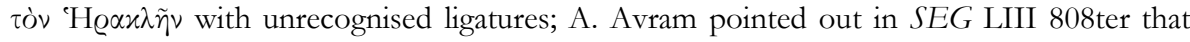
this monument is the same as SEG III 613]. [AC]

61) J.-C. DECOURT, Inscriptions grecques de la France, Lyon, 2004 [BE 2005, 626]: This corpus assembles all Greek inscriptions found in France. Massalia: Cults: A cult association dedicated an altar of Zeus Patroios (5, 2nd cent. AD). An inscription honours a priest of Leukothea, the son of a prophet $(8,3$ rd cent. AD). A small fragment may refer to Apollon Apotropaios (37). Funerary cult and afterlife: A funerary epigram (10, 3rd cent. AD) associates

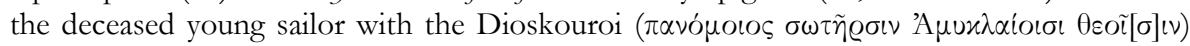

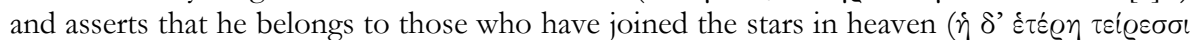

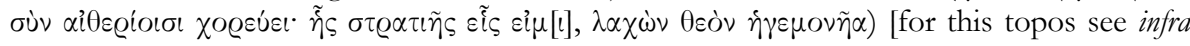
$\mathrm{n}^{\circ}$ 156]. Another epitaph gives the dates of birth and death of a young man with reference

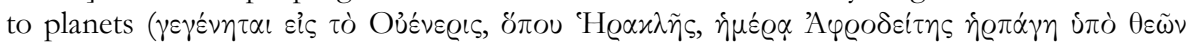

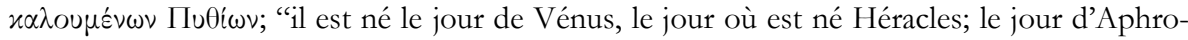
dite, il fut enlevé par les dieux invoqués sous le nom de Pythiens”) [cf. infra no 143; since

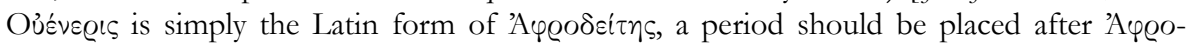

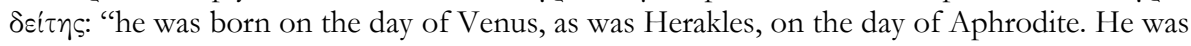
carried away by gods called the Pythians"]. D. interprets the Pythian gods as Apollon and Zeus Moiragetes. An epitaph uses the formula eủ $u \dot{x} \chi \varepsilon \iota$ (39, 3rd cent. AD). Aix-en-Provence

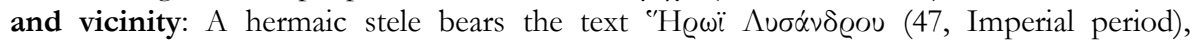
translated by D. as "au Héros de Lysandros". D. regards it as an apotropaic monument, rather than the epitaph of Heros, son of Lysandros (or the heroised son of Lysandros). Glanum and vicinity: A dedication to Apollon (51, 1st cent. BC). Arles and vicinity: We single out the formulae $\varepsilon^{3} \theta \dot{u} \mu(\varepsilon) \iota(55)$ and $\varepsilon^{\prime} \pi \lambda \circ \iota \alpha$ (56) in epitaphs of the Imperial period. Olbia: Inscriptions attests the cults of Aphrodite (64, 3rd/2nd cent.), Leto (65, 3rd cent.), a Heros (67, 3rd/2nd cent.), and Mother goddesses (66, M $\eta \tau \varrho \tilde{\omega} v ?$ ?, 2nd cent. BC). The most important group of texts consists of c. 350 graffiti on vases with dedications to Aristaios (2nd cent. BC-1st cent. AD), according to mythology a son of Apollon and Kyrene (or Chiron or Ge and Ouranos). Only 48 of these texts have been published. The dedications (cf. 68-37, 43: $\dot{\alpha} v \dot{\alpha} \theta \eta \mu \alpha)$ were made as expressions of gratitude (68-1, 28: $\chi \dot{\alpha} \varrho \iota v ; 68-4,5,6,8$, 


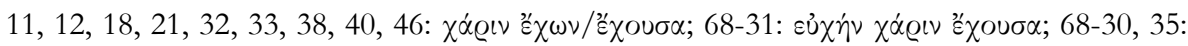

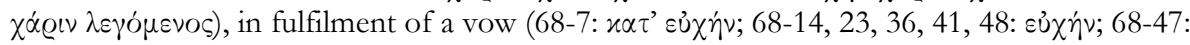

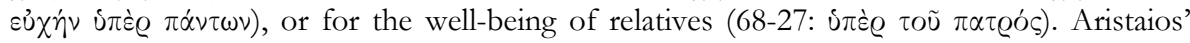
sanctuary consisted of a temenos with an altar (68-2). For a curse tablet (70) see EBGR 1997, 22. Département du Var: A Heros is mentioned in a text at Taurentum (78, 2nd cent.). Antipolis and vicinity: The most famous text is the 'galet d'Antibes', an oblongue

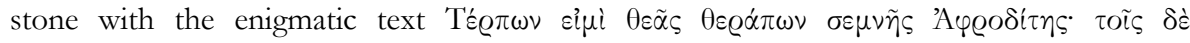

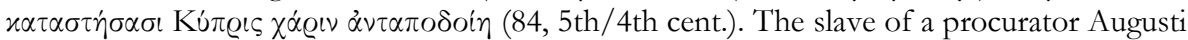
made a dedication in fulfilment of a vow he had made to Pan for his master $(85,1 \mathrm{st} / 2 \mathrm{nd}$

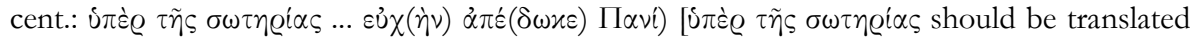
"for the rescue" (not "pour la santé") of the procurator, possibly for his safe return from a journey]. There are also dedications to the gods (80, Imperial period) and to the local divinities Leron and Lerine (86, 3rd/2nd cent.). Département du Vaucluse: A famous text is the Greek-Latin dedication of an altar to Baal/Belos, the master of Fortune, by Sextus, on the basis of oracles given in Apameia (87; Belus Fortunae rector mentisque magister ara gaudebit

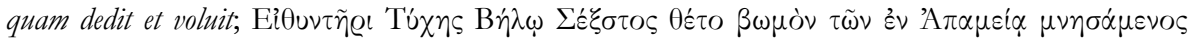
$\lambda o \gamma(\omega v)$. A bronze amulet aimed at the protection of the fields from bad weather $(90$, Imperial period) [cf. infra no 184] Département de la Drôme: A bronze amulet has a similar spell of weather magic as $n^{\circ} 90$ (91, Imperial period). Nemausos (Nîmes): Several fragmentary documents attest the activities of a local branch of the association of the

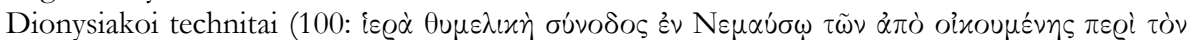

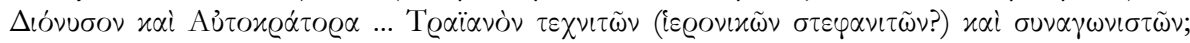
100-111, 2nd cent. AD). Département de l'Hérault: A dedication to the Materes and the Dioskouroi (128, Imperial period). Département de la Charente: A gold amulet is inscribed with seven sequences of the seven vowels (140). Lyon and vicinity: An epitaph

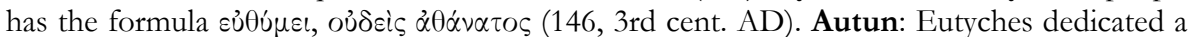

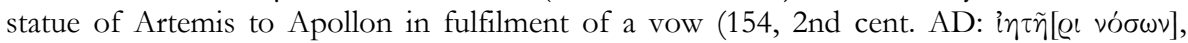

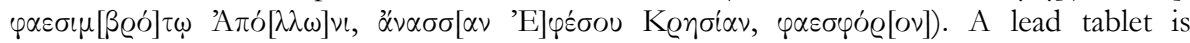
inscribed with six names in Latin (a defixio) on one side and with magical names and words (beginning with A $\beta \varrho \alpha \sigma \alpha \dot{\xi})$ on the other $(159,2$ nd cent. AD). [AC]

62) N. Deshours, "Cultes de Déméter, d'Artémis Ortheia et culte impérial à Messène", ZPE 146 (2004), p. 115-127: In 91 BC a certain Mnasistratos played a crucial role in the reform of the Andanian Mysteries (IG V.1, 1390; LSCG 65), for he had in his possession the sacred books needed for the reform (line 13) [this date has been questioned by P. Themelis; see infra $\mathrm{n}^{\circ}$ 268]. In exchange, Mnasistratos took over the probably hereditary priestly function of a hierophantes (line 22). According to D., this Mnasistratos appears in the contribution list IG V.1, 1532; he therefore belonged to one of the most wealthy, prestigious, and influential families of Messene in the 1st cent. BC. In AD 42 the gerontes of Artemis Oupesia (Ortheia) honoured a certain Mnasistratos, son of Philoxenidas, for his generous financial contribution in the Imperial cult and the cult of Artemis (SEG XXIII 208). The inscription explicitly stresses that Mnasistratos was in this respect a worthy scion

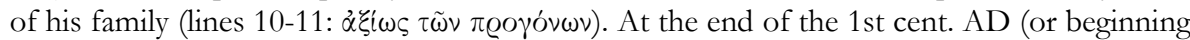
of the 2nd) Asklepiades, son of Mnasistratos, is characterized in an inscription as the star of

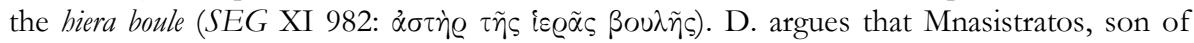
Philoxenidas, was a descendant of the man who had played a prominent role in the reform of the Andanian Mysteries. [But if the lex sacra of Andania should be dated to AD 24 (see infra $\mathrm{n}^{\circ}$ 268), the reformer of the mysteries is the son of Philoxenidas]. Asklepiades should be identified as the son of Mnasistratos, son of Philoxenidas, while the term biera boule most probably is another designation for the gerousia of (Artemis) Oupesia. According to D., we 
are dealing with a prominent Messenian family occupying a central positon in two of the most important cults of their native city. [On the Andanian Mysteries see now EAD., Les mystères d'Andania. Étude d'épigraphie et d'bistoire religieuse, Paris, 2006]. [JM]

63) G.I. DEsPINIS, "Die Kultstatuen der Artemis in Brauron", $M D A I(A) 119$ (2004), p. 261 315 [BE 2006, 44]: Six different terms appear in the inscriptions from the Brauronion on the Athenian Acropolis referring to statues which stood in the sanctuary of Artemis at Brauron:

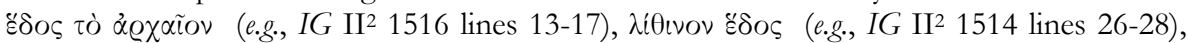

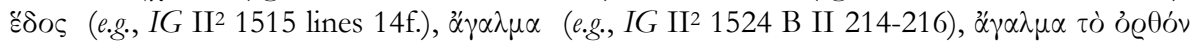

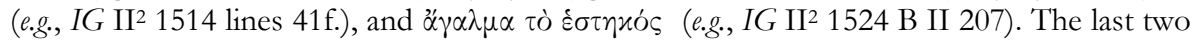
terms certainly describe the same divine image. Based on these epigraphic sources, modern research reconstructed either three or two cult statues at Brauron, but D. suggests that the epigraphical evidence documents the existence of five cult statues, while the archaeological evidence seems to add at least one more. According to D. these six cult statues stood in two

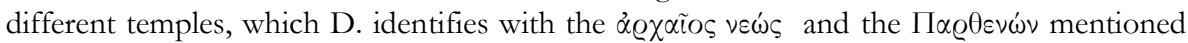
in inscriptions from the Brauronion (IG II ${ }^{2} 1517$ I, lines 3, 217; 1524 II 46-47) and in at least

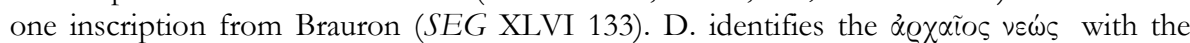
excavated architectural remains of the known temple in antis, while the $\Pi \alpha \varrho \theta \varepsilon v \omega \dot{\omega} v$ is interpreted as a small edifice which could have stood on the plateau, where the small chapel of St. George stands today [cf. EBGR 1996, 194; 2002, 104; 2003, 48]. [JM]

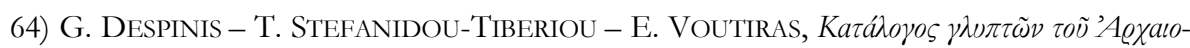

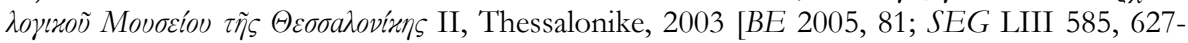
628, 638]: The second volume of the catalogue of sculpture in the Archaeological Museum in Thessalonike contains several dedications from Thessalonike (all of them in IG XII.2.1). They are addressed to: Isis Epekoos (177 = IG X.2.1, 98; with representation of an ear; 335 = IG XII.2.1, 120; representation of footprints; $x \alpha \tau^{\prime}$ ' ย̇ $\left.\pi \tau \alpha \gamma \eta \dot{\eta} \nu\right)$; Isis Tyche (332 = IG XII.2.1,

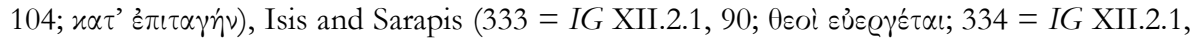
115), Isis Nymphe (336 = IG XII.2.1, 105); and the Nymphs (337 = IG XII.2.1, 63). There is only one ineditum, a dedication to Asklepios (152, 4th cent.; unknown provenance). [AC]

65) V. Di Benedetto, "Fra Hipponion e Petelia”, PP 59 (2004), p. 293-306: In this stimulating study D. comments on certain passages of the 'Orphic' texts from Petelia and

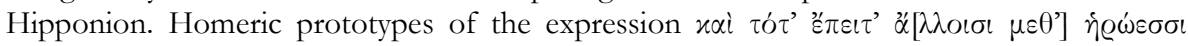
$\dot{\alpha} \nu \dot{\alpha} \xi \varepsilon \iota[\varsigma]$ in the text from Petelia suggest translating this passage as "e allora poi comanderai su gli altri eroi"; the mystes is attributed a superior status. By contrast, the text from Hippo-

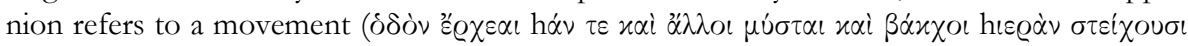
$\left.x \lambda \varepsilon v^{\prime} i\right)$, not to a status. The author detects another difference between the texts of Petelia and Hipponion in the answer given by the initiate to the guards of the underworld. While in the text of Hipponion the mystes is identified only as the son of the Earth and the Sky, the

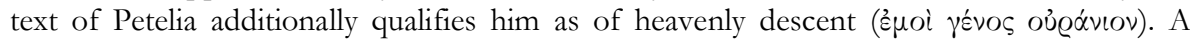
superior status is also implied by one of the texts from Thurioi which attributes to the

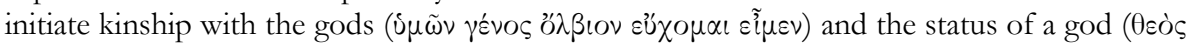
$\delta$ ' '̌ $\sigma \eta \imath)$. [Do these differences imply only different traditions within the Orphic movement or perhaps different grades of initiation?]. D. detects similarities in the phraseology of the text from Hipponion with the Homeric Nekyia. As regards the first line of this text [cf. infra

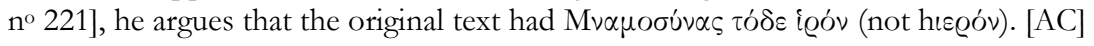

66) M. DiCKIE, "Priestly Proclamations and Sacred Laws", CQ 54 (2004), p. 579-591: The

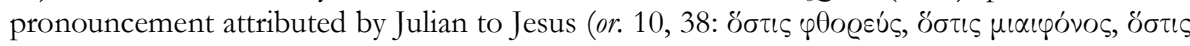

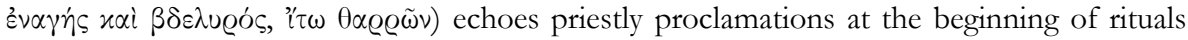

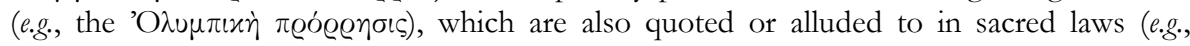




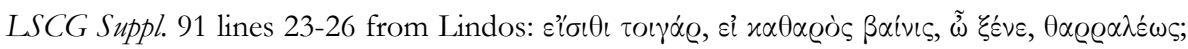
cf. the lex sacra of Antiochos of Kommagene in the copy at Arsameia [see supra $\mathrm{n}^{\circ}$ 57], lines

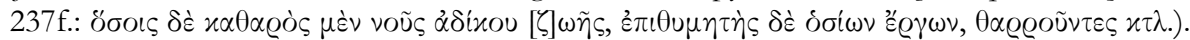
D. collects many literary testimonia for this practice [for $\theta \alpha \varrho \varrho \varepsilon \tilde{\nu}$ in this context $c f$. the use of this verb in Isyllos' hymn to Asklepios (IG IV² 128 line 73: $\theta \dot{\alpha} \varrho \sigma \varepsilon \iota)$ and the aretalogy of Isis in Maroneia (SEG XXVI 821 lines 11f.: $\theta \alpha \varrho \varrho \tilde{\omega} v$ oũv $\pi \circ \varrho \varepsilon v ́ o \mu \alpha l)]$. Such pronouncements have the form of a series of asyndetic relative clauses and conditional sentences, perhaps following the model of the prorrhesis of the Eleusinian mysteries. [AC]

67) B. Dignas, “'Auf seine Kosten kommen’ - ein Kriterium für Priester? Zum Verkauf von Priestertümern im hellenistischen Kleinasien", in Religionsgeschichte Kleinasiens, p. 27-40: D. presents an overview of the sale of priesthoods (cf. EBGR 2000, 151; 2001, 151; 2003, 182-183). Geographically the selling of priesthoods is observed almost exclusively in cities of southwest Asia Minor and in some islands of the Eastern Aegean. Chronologically the main corpus of evidence dates between the 4th and the 1 st cent. BC, although there are still some sporadic examples from the 2 nd and 3 rd cent. AD. D. discusses briefly the relevant

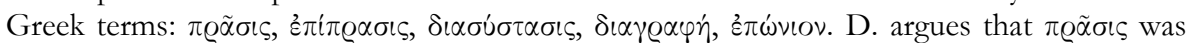
used to refer to the sale of a priesthood in the main cult centre, while the sale of a priesthood in a dependency was designated as ė $\pi i \pi \varrho \alpha \sigma \iota s$. D. attributes the absence of sales of priesthoods in Mainland Greece to the more democratic structure of its cities as compared to cities in Asia Minor. In the discussion of the duties and privileges of priests who bought priesthoods, D. aptly stresses that there was no real difference between the different kinds of priesthoods as regards prestige, duties, etc. [JM]

68) J.H.F. DijKSTRA, “A Cult of Isis at Philai after Justinian? Reconsidering P.Cair.Masp. I 67004", ZPE 146 (2004), p. 137-154: A study of a long petition in Antinoopolis referring to the activities of the Blemmyes in AD 567 suggests that the Blemmyes were still worshipping Isis, despite the decline of her sanctuary at Philai in the 5th cent. [JM]

69) A. Dimartino, “Omicidio, contaminazione, purificazione: il 'caso' della lex sacra di Selinunte", ASNP 8 (2003) [2006], p. 305-349: In one of the most substantial recent contributions to the study of the lex sacra from Selinous concerning purification (SEG XLIII 630) [cf. EBGR 1996, 45; 2002, 93 with further references, supra $\mathrm{n}^{\circ} 32$ and infra no 74], D. reprints the text (with Italian translation) and discusses the interpretation of several crucial passages. The most important contribution concerns the interpretation of ė $\lambda \dot{\alpha} \sigma \tau \varepsilon \varrho o \varsigma$. In the light of references to $\alpha \lambda \dot{\alpha} \sigma \tau \omega \varrho$ in literary sources, in particular in Athenian drama, D. interprets the elasteros as the evil spirit that had caused the manslaughter that needs to be purified, and not the avenging spirit (p. 319-324). [The similarity to the parallels adduced by D. is striking, but a difficulty remains: purificatory rituals are usually concerned with the effect, not the cause of a deed that produces miasma]. D. also makes significant contributions

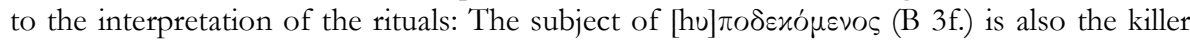

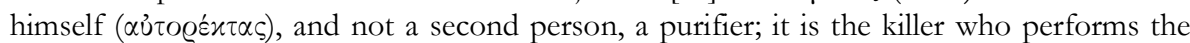
purificatory rituals described in B 4-7, for which D. adduces parallels from literary sources especially Attic drama and Apollonios Rhodios (Argon. III, 1039; p. 325-328). 'E $\pi \varepsilon i$ in the

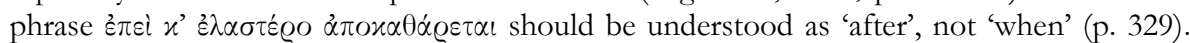
The literary evidence for the evolution of archaic laws concerning manslaughter suggests that this text envisages involuntary killing (p. 334-345). Both sides of the document refer to rituals concerning the same individual, but the traditional order of the two sides should be reversed: the rituals on side $B$ are of a private nature and were performed first, followed by the rituals described on side A (p. 332-334 and 345-347). [AC] 
70) N. Dimitrova - K. Clinton, "Dedication of a Statue for the Egyptian God Tithoes", ZPE 148 (2004), p. 207-210 [BE 2005, 597]: A new limestone stele from the area between Koptos and Shenhur in Egypt (AD 210) kept at Cornell University refers to the dedication of a statue of the god Tithoes by an anonymous high priest of Osiris, Tithoes, and Ammon

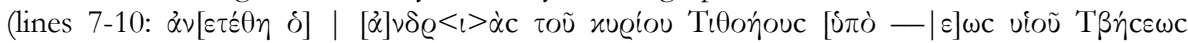

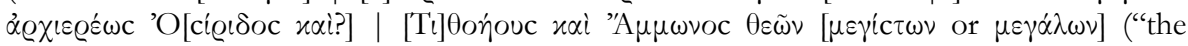
statue of our lord Tithoes was dedicated by X, the son of Tbesis, high priest of the great[est] gods Osiris, Tithoes, and Ammon"). The inscription may attest the existence of a joint sanctuary of Osiris, Tithoes, and Ammon. D.-C. point out that the term $\alpha \nu \delta \varrho\llcorner\alpha c$ is untypical as a designation of a statue of a divinity and suggest that it is used here to designate an anthropomorphic image of the god. [While $\alpha \dot{v} \delta \varrho<\dot{\alpha} \mathrm{c}$ is indeed not the most common word for images of gods, there are still many examples of its use in such a context; $c$. S. BETTINETTI, La statua di culto nella pratica rituale greca, Bari, 2001, p. 37-42]. [JM]

71) R. DiNÇ - G. MEYER, "Mélanges de cultures et de populations à Tralles d'après deux nouvelles inscriptions", Mediterraneo Antico 7 (2004), p. 287-315: Ed. pr. of a dedication to the Nymphs (early 4th cent.) by a Karian (p. 287-300). In a survey of the cult of the Nymphs in Karia, D.-M. present an improved version of I.Tralleis 15 (p. 300-305). This votive relief, with a representation of the Nymphs, was dedicated to Pan after an individual

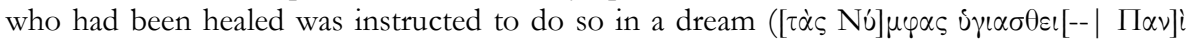

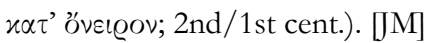

72) L. DOMARADZKA, "Catalogue of Graffiti Discovered during the Excvations at PistirosVetren 1988-1998. Part One: Graffiti on Imported Fine Pottery”, in J. BOUZEK L. Domaradzka - Z. H. Archibald, Pistiros II. Excavations and Studies, Prague, 2002, p. 209-228 [SEG LII 711]: The graffiti on vases found in Pistiros (Thrace, 5th-3rd cent.)

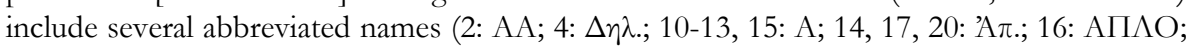

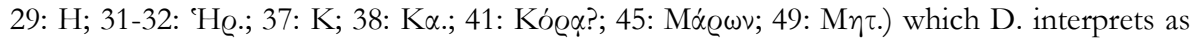
the names of deities (Artemis and/or Apollon, Apollon Delios, Hera or Herakles, Kora, the Kabeiroi, the Thracian hero Maron, and Meter) to which the vases were dedicated [cf. SEG XLVI 874; XLIX 912]. № 33 (iє.) may be a form of ir@óc. D. tentatively associates no 48 ( $\mu \dot{\eta}$

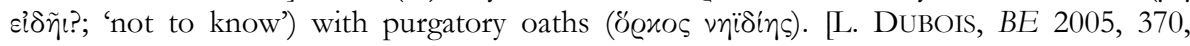
observes that the abbreviation $\Delta \eta \lambda$. is more likely a Greek personal name (without excluding the possibility of the Thracian $\Delta \eta \lambda \dot{\pi} \tau \tau \chi \chi \varsigma \varsigma)$. Kó $\propto \alpha$ is the Dorian form of Kó $\eta$, Maron a Thracian theonym. We remark that all these abbreviations could be abbreviated personal

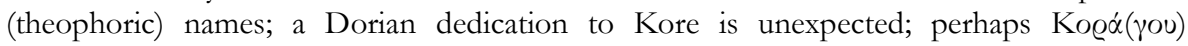
(Korragos is a very common Macedonian name)]. [AC]

73) T. DreW-BeAr - G. LABARRe, "Une dédicace aux Douze Dieux lyciens et la question de leur origine", in Les cultes locaux, p. 81-101: Ed. pr. of a small fragmentary relief (late 2nd/early 3rd cent.) in the private collection Alp Sarn in Ankara (no 107-97). A dedicatory inscription identifies the object as a votive offering to the Twelve Gods by Hermaios, upon their command ( $\left.x \alpha \tau^{\prime} \varepsilon \dot{\varepsilon} \pi \tau \alpha \gamma \eta^{\prime} \nu\right)$. The relief belongs to the well-known group of Lykian reliefs dedicated to the Twelve Gods [cf. EBGR 1993/94, 84; 1994/95, 286]. The authors convincingly reject the assumption that the Twelve Lykian Gods have anything to do with the Greek Twelve Gods, the Hittite Twelve Gods, or the Twelve Gods referred to in a bilingual inscription from Xanthos (TAM I 44, 5th cent.). They suggest that the emergence of this cult is a local Lykian phenomenon of the late 2 nd and early 3 rd cent. AD. [JM]

73bis) B. Dreyer - H. EngELMAnN, Die Inschriften von Metropolis. Teil I. Die Dekrete für Apollonios: Städtische Politik unter den Attaliden und im Konflikt zwischen Aristonikos und Rom, Bonn, 2003 (IGSK, 63) [BE 2004, 280-282; 2005, 401, 403; SEG LIII 1312]: Ed. pr. of a 
very important dossier consisting of two honorary inscriptions for Apollonios, a prominent statesman and military leader of Metropolis, who fell in a battle near Thyateira during the war against Aristonikos (in $130 \mathrm{BC}$ accoding to D.-E.) [in $132 \mathrm{BC}$ according to C. P. JONES, "Events Surrounding the Bequest of Pergamon to Rome and the Revolt of Aristonicos: New Inscriptions from Metropolis", JRA 17 (2004), p. 469-485]. The two documents, a posthumous honorary inscription (A) and an earlier honorary decree (B, 145/4 BC), were inscribed on the base of a statue in the agora of Metropolis. The later decree is dated with reference to an eponymous priest (perhaps of Meter or Ares) and to the priest of Roma, whose cult was probably introduced after the death of Eumenes III (133 BC). The posthumous honorary decree authorises Apollonios' son to construct a heroon in front of

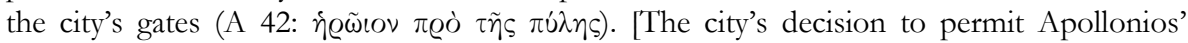
burial in front of the city gates was probably motivated partly by the idea that he would posthumously protect his city; this idea is, e.g., expressed in the grave epigram in Smyrna

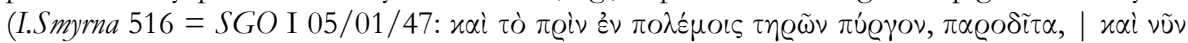

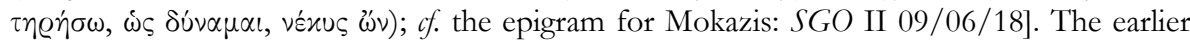
decree in honor of Apollonios refers to a sacrifice to Ares; according to the restoration of D. -E., this sacrifice was offered by Apollonios together with the presbyteroi on behalf of the

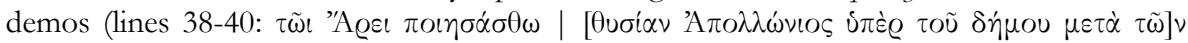

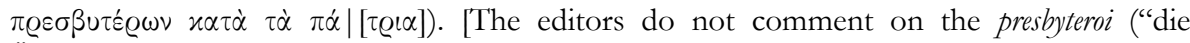
Älteren"); they were not older citizens, but the older group of the young citizens who served

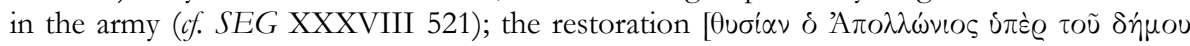

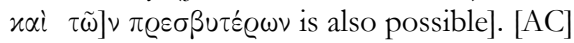

74) L. DuBOIs, La nouvelle loi sacrée de Sélinonte, CRAI (2003), p. 105-125 [SEG LIII 1032]: D. presents a new critical edition and analysis of the lex sacra of Selinous concerning the purification of those who have committed manslaughter (SEG XLIII 630) [cf. supra n ${ }^{\text {os }} 32$

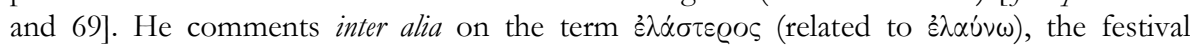

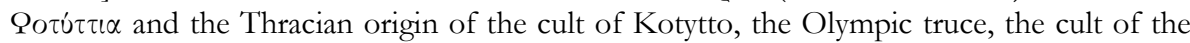
Eumenides and Zeus Eumenes ( $c f$. the theophoric name Eủ $\mu \varepsilon v i \delta o \tau o \varsigma$ in Selinous and the

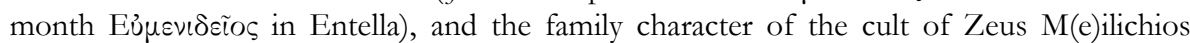
practiced in cult places of ancestors. As regards the rites for the Tritopatores (A 9-17; cf. the sacrifices for the $\gamma \varepsilon v \varepsilon$ é of a wine libation through an opening of the monument (A 10f.: $\delta \imath^{\prime}$ óeó $\varphi$ o) is paralleled by Pausanias X, 4, $10\left(\delta \iota^{\prime} \partial \pi \tilde{\eta} s\right)$ and a structure in the tomb of Kineas at Aï Khanoum, but

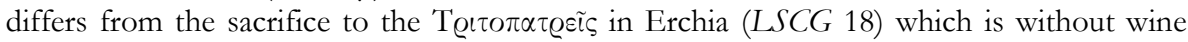
( $\left.\eta \varphi \dot{\alpha} \lambda_{\iota} \circ\right)$ ). D. discusses the similarity of the reintegration rites (B 1-13) with those prescribed by the cathartic law of Kyrene (SEG IX 72 lines 110-142), the customs of the Eupatrides in Athens (Athen. 323f $14=$ FgrHist 356 F 1), and Plato (Laws 865d). He assumes that the reintegration rite was performed by the closest relative of the person who has been killed (the subject of $\delta$ ó $\tau \omega$ in B 4), but in B 6 the subject changes and the text

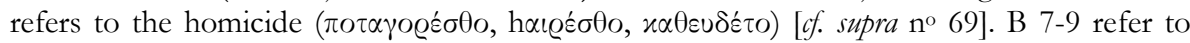

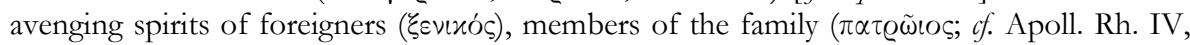

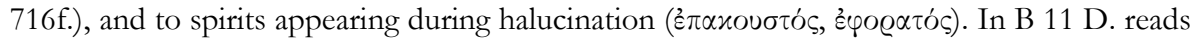

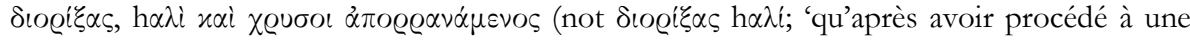

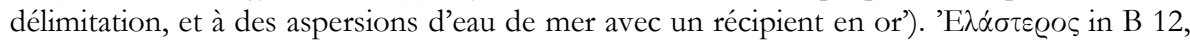
i.e., Zeus Elasteros, who represents the angry spirits of the persons who have been killed [but see supra $\mathrm{n}^{\circ}$ 69], receives a sacrifice ( $\left.\sigma \varphi \alpha \zeta^{\prime} \varepsilon \omega \varepsilon^{\prime} \zeta \gamma \tilde{\alpha} \nu\right)$, which reflects the ambiguous nature of this god who is associated with chthonic and family cults. [AC]

75) L. DubOIS, "Bulletin épigraphique", REG 117 (2004), p. 578-720 [SEG LIII 485]: D. (p. $585 \mathrm{n}^{\circ}$ 11) proposes understanding the word ENATO $\Sigma$ in the sacred regulation of the 
Labyadai (Delphi, c. 350; CID I 9) as an antonym of $\ddot{\alpha} \pi \alpha \tau o \varsigma$ ( $c f . \dot{\alpha} \nu \dot{\alpha} \alpha \tau$ ) in IG V.2, 357 line 177 and $\alpha \dot{\alpha} \alpha \tau$ \%ov in I.Cret. IV 46 B 9), i.e., 'en faute', 'polluted'. According to this clause (lines 37-39), whoever assisted in the inhumation of a dead person was regarded as polluted until earth ( $\theta \iota \gamma \alpha \dot{\alpha} \nu$; cf. Hesych., s.v.) covered the body. Id. (p. 607 no 121) interprets $\pi \varrho o \theta \varepsilon \alpha \varrho \varrho \alpha$ in a text from Kyrene either as sacrifices preceding consultation of an oracle or as a sacrifice in honour of theoroi. [AC]

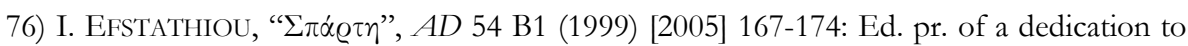
Tiberius, called soter (p. 174; Sparta). [AC]

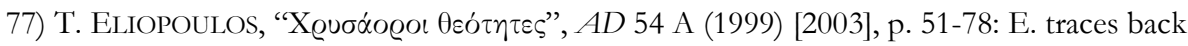
to the Mycenaean period the idea of a god bearing a golden sword. This explains the epithet

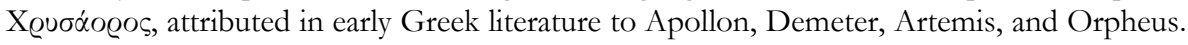
The cult of Zeus Chrysaoreus in Caria may have its origin in the period of Late Mycenaean expansion on the Carian coast. A decree of Xanthos (SEG XXXVIII 1476) mentioning Chrysaor may reflect the memory of this period. [AC]

78) H. Elton, "Romanization and Some Cilician Cults", in L. DE LiGT - E.A. HemelRIJKW. Singor (eds.), Roman Rule and Civic Life: Local and Regional Perspectives, Amsterdam, 2004, p. 231-241: E. discusses briefly two altars from the Korykian cave in Kilikia for Zeus and Hermes, both bearing the epithets Korykios, Epinikios, Epikarpios, and Tropaiouchos (I.Cilicie 16 and 17, early 3rd cent. AD), and an epitaph from Kanlidivane (territory of Sebaste) in which M. Ulpius Knos threatens anyone who damages or opens the tomb with a fine payable to the treasuries of Zeus, Selene, and Helios, with a curse, and with punishment

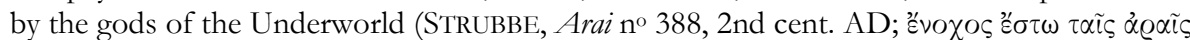

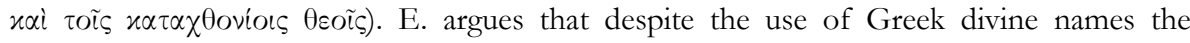
combination of Zeus and Hermes in Korykos and of Zeus, Helios, Selene, and the gods of the Underworld in Sebaste reveal the continuation of local religious practices and beliefs in a Hellenized and Romanized framework. [JM]

79) D. ERKELENZ, “ $1+1=3$ ? Überlegungen zur Interpretation der Inschriften von Ephesos 501 und 647”, EA 37 (2004), p. 115-120 [BE 2005, 406]: A statue base (originally made out of three stone blocks, of which two are still preserved) opposite the library of Celsus, bears on its left side a dedication to Androklos, the mythical founder of the city, by Aurelius Neikostratos (I.Ephesos 501, 3rd/4th cent.). The base probably supported a statue of Androklos. On its front side there is a bilingual inscription with the Greek text on the upper and the Latin one on the lower part of the base (I.Ephesos 647). E. shows that the two parts cannot belong together and proposes the following reconstruction: Originally, the Greek and the Latin inscription of I.Ephesos 647 were part of two different monuments dismantled at some point before the $3 \mathrm{rd}$ cent. AD. Neikostratos used parts of these two monuments (the Greek and Latin parts of I.Ephesos 647) and joined them with a third block, now lost, to make the base of the statue he dedicated to Androklos. [JM]

80) C.A. FARAOnE, "New Light on Ancient Greek Exorcisms of the Wandering Womb", ZPE 144 (2003), p. 189-197 [BE 2004, 77]: F. collects the rather scant evidence for exorcisms aiming at curing the condition known as the wandering womb. To two magical papyri (PMG VII 260-27, 3rd/4th cent.; PMG 12, 6th/7th cent.) may now be added an amulet in Beirut (EBGR 1994/95, 199 p. 265-269, 1st cent. BC/AD), a lead amulet in Britain (4th cent. AD) [infra no 277], and an Aramaic recipe from the Cairo Genizah (7th cent. AD or later). All these texts, re-edited by F. with commentary and translation, reflect the same tradition: they address the womb of a woman and order it to curtail its movement 


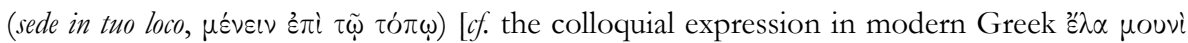

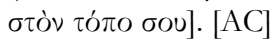

81) C.A. Faraone, "The Collapse of Celestial and Chthonic Realms in a Late Antique 'Apollonian Invocation' (PMG I 262-347)”, in R.S. BOUSTAN - A.Y. REED (eds.), Heavenly Realms and Earthly Realms in Late Antique Religions, Cambridge, 2004, p. 213-232: Apollon appears as a source of oracular inspiration in magical papyri as a celestial deity (PMG II 64184; III 187-262 and 282-409); the texts imply that the practitioner dressed like Apollon's prophets at Didyma, Delphi, and Klaros, creating a miniature Apollonian oracle and attracting the god by singing a hymn. What is unusual in another late antique magical papyrus with a divinatory spell invoking Apollon (PMG I 262-437) is the combination of the celestial and the chthonic spheres, which the Greeks were accustomed to keep apart; the god is expected to descend to the underworld and send a ghost to speak to the practitioner. This should be seen in the context of the syncretistic tendencies of late Antiquity. The identification of Apollon/Helios with the Egyptian Re and the Mesopotamian Shamash lead to the idea that the solar deity descends to the underworld. Other Apollonian invocations regard Apollon's descent to the underworld only as a possibility ('if you go into the hollow of the earth and to the land of the dead'); they may have adapted a spell which originally invoked Hermes, replacing Hermes' name with that of Apollon. The author of this spell removed this condition because he regarded Apollon as the equivalent of Re and expected him to descent to the underworld; he created a hybrid hymn, in part a cletic hymn to Apollon, originally designed to summon the god to inspire the practitioner with prophetic verses, and in part a metrical request of necromancy. [JM]

82) S. FOLLET, "Bulletin épigraphique", REG 116 (2003), p. 614 no. 311: In a sacred law

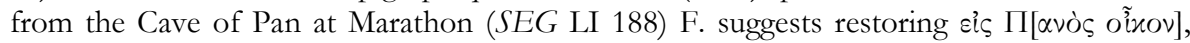
instead of $\varepsilon i \sigma \pi[o \varrho \varepsilon v i \varepsilon \sigma \theta \alpha$ ] . [For a different restoration see EBGR 2001, 115; the text is republished as NGSL 4]. [AC]

83) S. FOLLET, "Éloge d'un gymnasiarque d'Athènes ou d'Égine (IG IV 4 = EM 8942)", in Attikai Epigraphai, p. 213-224: IG IV 4, a fragmentary honorary decree for a former gymnasiarch whose name is not preserved, was rediscovered in the Epigraphical Museum at Athens. After a new study, F. proposes several intriguing restorations. Lines $5 f$. certainly refer to the performance of a sacrifice to Hermes and Herakles in the gymnasion at the

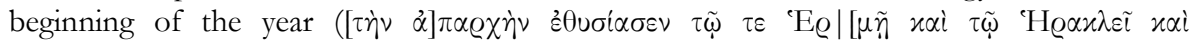
$\varepsilon \sigma] \pi \lambda \dot{\alpha} \nu \chi v \varepsilon \cup \sigma \varepsilon v)$. The use of the verb $\sigma \pi \lambda \alpha \nu \chi v \varepsilon \dot{\omega} \omega$ is unusual; it indicates that the honorand not only performed the sacrifice but was also responsible for the examination of the entrails. F. is more cautious regarding the restoration of the last three lines, which may refer to the funding of the sacrifice in the gymnasion during a festival, perhaps the celebration of

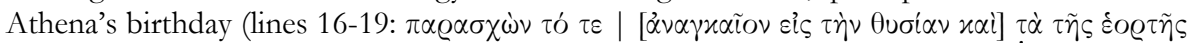

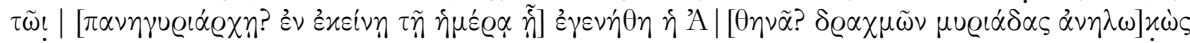
$\delta \varepsilon x \alpha \hat{\varepsilon}[\xi]) . F$. dates the inscription to the 1 st cent. AD, but the question of provenance (Athens or Aigina) remains unanswered, although F. seems to favour an Athenian origin. [JM]

84) S. Follet - D. Peppas Delmousou, "La légende de Thésée sous l'empereur Commode d'après le discours d'un éphèbe athénien, $I G \mathrm{II}^{2} 2291$ A+1125 complétés", in Romanité et cité chrétienne, permanences et mutations, intégration et exclusion du Ier au VIe siècle. Mélanges en l'honneur d'Yvette Duval, Paris, 2000, p. 11-17 [BE 2003, 293]: The authors observed that an inscription from Athens containing an oration in praise of Theseus delivered by P. Aelius Isochrysos, the archon ton ephebon, during the celebration of the Theseia in AD 184/5 (IG II 2291 A) joins with a fragment thought to be an imperial constitution ( $\left.I G I^{2} 1125\right)$. This permits a 


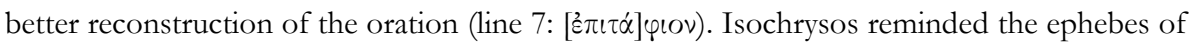

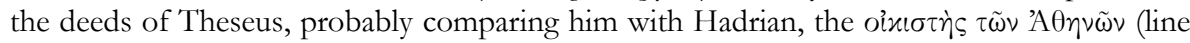
31 ), and urged the ephebes to follow his example. This text is of great interest for understanding the role of orations in the celebration of the Theseia in the imperial period and the part played by myth in the education of ephebes. [AC]

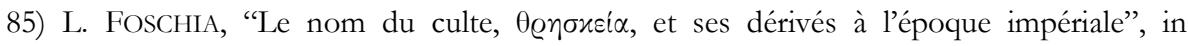
L'hellénisme d'époque romaine, p. 15-35: The term $\theta$ enousia and its derivatives seem to be absent from the Hellenistic epigraphic material, but they make their appearance from the Augustan period onwards; their use in inscriptions becomes more and more frequent during the 1 st cent. AD. The initial meaning of the term Oenoxsia ("cult regulations") gradually acquired the broader meaning "cult" and finally, in the process of Romanisation, it became a synonym of Roman religio. F. discusses the relation bertween $\theta \varrho \eta \sigma x \varepsilon i \alpha$ and $\varepsilon \dot{\sigma \varepsilon} \beta \varepsilon \varepsilon \alpha$, the use of the term in funerary contexts, and the use of the term $\theta \varrho \eta \sigma x \varepsilon v \tau \dot{\eta} s$ in connection with Egyptian cults, but also with the cults of Aphrodite Paphia, Zeus Hypsistos [for a new attestation in Dion see SEG LIII 596; cf. EBGR 2003, 125], and the hero Pergamos. In a

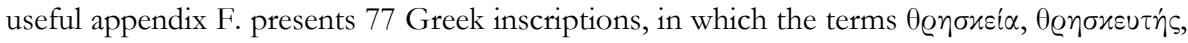
and $\theta \varrho \eta \sigma \varkappa \varepsilon \dot{\omega} \omega$ occur. [JM]

86) P.M. Fraser, "Agathon and Kassandra (IG IX.12.1750)", JHS 123 (2003), p. 26-40 [SEG LIII 570]: A bronze plaque, decorated with male genitals, was offered as a dedication

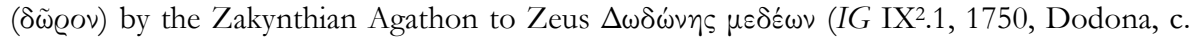
$330 \mathrm{BC}$ ); according to the current interpretation, Agathon regarded himself as a direct descendant of Kassandra. However, F. changes the punctuation and reads: 'A $\gamma \dot{\alpha} \theta \omega \nu$

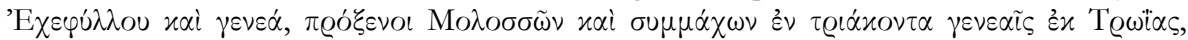

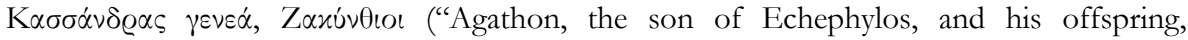
proxenoi of the Molossians and their allies throughout thirty generations from Troy, the race of Kassandra, Zakynthians"). The relation of proxeny between the Molossians and Agathon's ancestors may well have been established at an early date. The relations between Zakynthos and Troy were based on mythological narratives (the ktistes Zakynthos was a son of Dardanos; Aeneas stopped at Zakynthos); Agathon may have traced his family tree back to Helenos, Kassandra's twin brother who settled at Dodona, or Agathon, another of Priam's sons. F. interprets the phallus that decorates the bronze plaque as an allusion to the

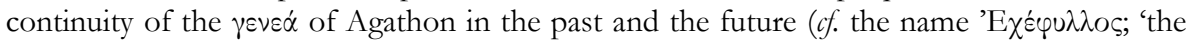
stock preserver'). [AC]

87) D.H. French, The Inscriptions of Sinope. Part I. Inscriptions, Bonn, 2004 (IGSK, 64) [BE 2005, 469; BE 2006, 554]: The first volume of the corpus of Sinope contains 224 inscriptions. Leges sacrae: A document describes the rights and responsibilities of the priest of Poseidon Helikonios $(8=L S A M 1$, 4th cent.); F. suggests that the crown worn by the priest

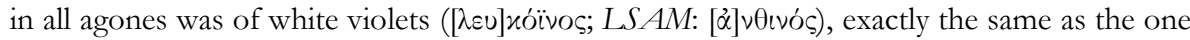
worn by the magistrates (timouchoi). [Did all the agones in Sinope take place in months in which white violets grew?]. Dedications to: Asklepios Soter and Hygeia (110, 1st/2nd cent.; an

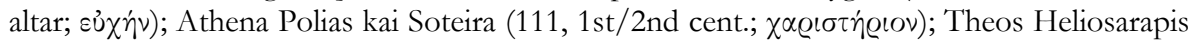

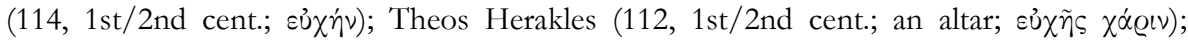
Hestia Prytaneia by the prytaneis (7, 4th cent.); Meter Theon (113,1st/2nd cent.; a statuette,

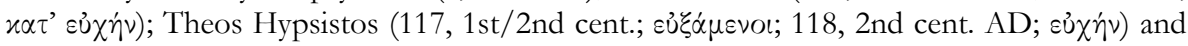

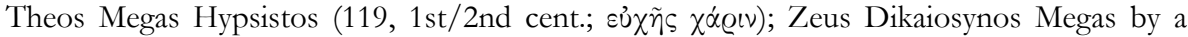
general (75, 2nd/1st cent.; $\chi \propto \varrho \iota \tau \eta \dot{\varrho \iota r v) ; ~ Z e u s ~ H e l i o s ~ N a u[. .] m e n o s ~ E p e k o o s ~(120 ; ~ 2 n d / 3 r d ~}$

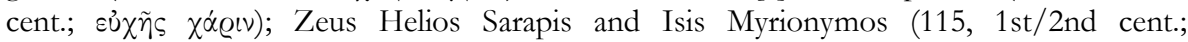
єủ $\dot{\alpha} \mu \varepsilon v o \varsigma)$. A (posthumous?) honorary statue for Rheipane was erected near the temple [or 


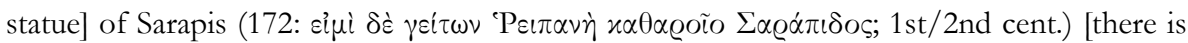
nothing in the text to suggest that the young woman was a priestess of Sarapis]. Priesthoods: A funerary epigram was written on the grave of a priestess of Leukothea ( $84=E B G R$ 2000, 140). Claudia Paula, of senatorial status, served as priestess of Thea Isis (103, 1st/2nd cent.). T. Veturius Campester accumulated the priesthoods of the emperors and Deus Mercurius and the office of augur (102). [No 212 (1st/2nd cent.) mentions a sacerd(os)]. Emperor cult: A Pontarches celebrated gladiatorial combats, venationes and taurokathapsia (103); there is a mention of a priest of all the emperors (102: sacerdos omnium Caesarum). Dedications (mostly in Latin) are addressed to Antoninus Pius (87), Marcus Aurelius (88-89), Marcus Aurelius and Commodus (90), and Marcus Aurelius Divus (91,*92). Festivals and contests. In the Imperial period, there are references to agonothetai (101), public banquets (101), and a panegyriarches (102). An agonistic inscription for the boxer M. Iulius Marcianus Maximus refers to his victories in the following contests: Capitolia in Rome, [Sebasta] in Neapolis, Aktia, Nemeia, Isthmia, Pythia, Olympia, Panathenaia, Pythia in Antiocheia, Aspis in Argos, unnamed agones in Antiocheia, Nikomedeia, Philadelpheia, Tralleis, Hierapolis, Laodikeia, Thyateira, Mytilene, and the provincial agones of Asia (Koina Asias) in Smyrna, Ephesos, Pergamon, and Sardeis, of Pontos, Galatia, Macedonia, Bithynia (in Nikaia), and Kappadokia, as well as 110 hemitalantiaioi agones (105, 1st/2nd cent.). A fragmentary inscription honours another athlete $(* 106,2$ nd cent. AD) [possible restorations are 'O $\lambda \dot{\mu} \mu[\pi\llcorner\alpha]$ or

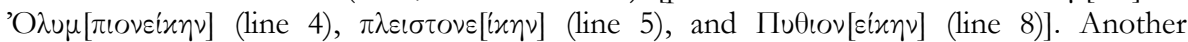
fragment refers to a paradoxos (107). Afterlife and funerary cult: A man who died at the age of 20 is called in his epitaph 'a noble hero' (141: $\alpha \gamma \alpha \theta \tilde{\varphi}$ E̋ $\varrho \omega t$; Imperial period) [rather 'benevolent hero']. A funerary imprecation uses the curse formula 'unburied he shall satiate

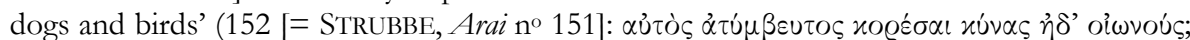
cf. Iliad XIII, 831; 1st/2nd cent.). A funerary epigram for a ship-captain refers to his "last

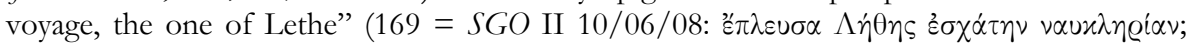
1 st/2nd cent.). Oath: A treaty of alliance between Sinope and the tyrant family of Herakleia (*1, c. 353-345) refers to a treaty oath (horkion) which is not preserved on the stone. Calendar. The month names Taureon, Poseideon (8), and Panemos (7) are attested in the 4th cent. Superstition: An inscription on a block lists Themis along with names with astrological connotations: Helios, Selene, Hermes, Hydrochoos (Aquarius), and Seirios (116, 1st/2bd cent.). Christianity and Greek religion: A Christian honorary epigram refers to the skill of the

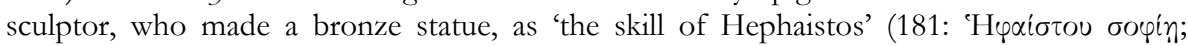
4th/5th cent.). Onomastics: We do not list the many thephoric names, but we single out a few personal names alluding to cults or religious practices: Choregion (7), Delphinios, son of Orgiales (14) [allusions to Apollon Delphinios? and Dionysos], Hikesios (25) and Hikesie (60). [AC]

88) F. FRISONE, "Il rituale come campo di sperimentazione del 'politico': l'esempio della normativa sul rituale funerario nella documentazione epigrafica greca", in S. CATALDI (ed.), Poleis e politeiai. Esperienze politiche, tradiæioni letterarie, proggetti costituæionali, Alessandria, 2004, p. 369-384: Continuing her studies on the funerary legislation of Greek cities (cf. EBGR 1996, 92; 2001, 61), F. here discusses in particular its political relevance, focusing on the relevant inscriptions from Delphi (CID I $9=$ LSCG 77), Ioulis (LSCG 97), and Gambreion (LSAM 16) [see now E. STAVRIANOPOULOU, "Die 'gefahrvolle' Bestattung von Gambreion", in C. Ambos et al. (eds.), Die Welt der Rituale von der Antike bis heute, Darmstadt, 2005, p. 24-37]. [AC]

89) G. Fuks, “A Mediterranean Pantheon: Cults and Deities in Hellenistic and Roman Ashkalon”, Mediterranean Historical Review 15.2 (2000), p. 27-48: Using the extant literary, epigraphic, and literary evidence, F. presents an overview of the cults attested at Ashkalon: 
Apollon, Asklepios, Astarte/Aphrodite, Atargatis/Derketo, Athena (?), the Dioskouroi, Herakles/Melkart, Hekate, Hermes, Pan (?), Phanebalos, Poseidon, Tyche, Zeus, and the Egyptian gods. The Phoenician cults are predominant; Greek cults played a minor part. [AC]

90) S. Georgoudi, "Gaia/Gê, entre mythe, culte et idéologie", in S. Des Bouvrie (ed.), Myth and Symbol. I. Symbolic Phenomena in Ancient Greek. Culture. Papers from the First International Symposium on Symbolism at the University of Tromso, June 4-7, 1998, Bergen, 2002, p. 113-134: G. summarizes the Greek conceptions of Gaia with reference to the cult of Ge Karpophoros (IG II ${ }^{2}$ 4758), Ga Makaira Telesphoros (IG VII 245), and Ge Meter Olybris Thea Despoina (SEG XLII 1322). Despite the great cosmic and ideological significance of the Earth and the civic territory, the cult of Gaia remained a peripheral phenomenon in Greek religion. [AC]

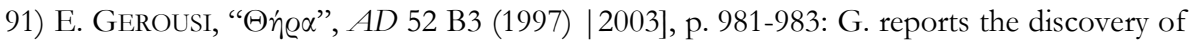
five plaques and a stele with epitaphs recording the heroisation of the deceased individuals

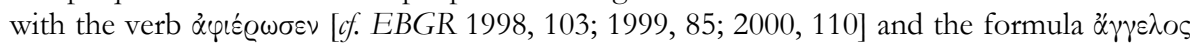
+ name of a person in the genitive ( $c$. G. KIOURTZIAN, Recueil des inscriptions grecques chrétiennes des Cyclades de la fin du III au VII siècle après J-.C., Paris, 2000, p. 247-282 nos 1-60]. [AC]

92) F. GHINATTI, "Problemi di epigrafia cretese. La diffusione della koine", MEP 6 (2001) [2002], p. 35-142: In a general study of the language of Cretan inscriptions, G. discusses inter

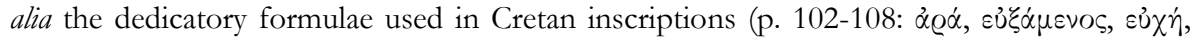

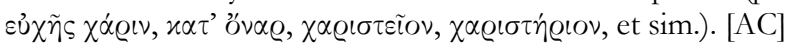

93) A. GIOVANNINI - M. HiRT, "L'inscription de Nazareth : une nouvelle interprétation", ZPE 124 (1999), p. 107-132 [SEG XLIX 2071]: This document (SEG VIII 13), allegedly

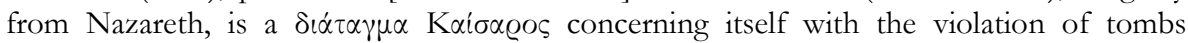
( $\left.\tau \mu \beta \beta \omega Q v \chi^{i} \alpha\right)$ and imposing the death penalty for the removal of interred bodies in the future. The text has often been regarded as a response by the Roman administration to the suspicion that the followers of Christ had opened the tomb and abducted his body [ $c f$. more recently E. GRZYBEK - M. SORDI, "L'édit de Nazareth et la politique de Néron à l'égard des Chrétiens", ZPE 120 (1998), p. 270-291]. Observing that most inscriptions that mention $\tau \cup \mu \beta \omega Q u \chi^{i} \alpha$ come from Asia Minor and that this crime corresponds to a Roman legal concept, G.-H. reject both the attribution of this document to Nero and the assumption that it was found in Nazareth and is related to a specific event. They attribute this edict to Octavian, date it to the period immediately after his victory at Actium, and place it in the

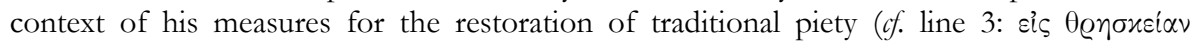
$\pi \varrho o \gamma o ́ v(\omega v)$. Octavian may have issued the edict during his visit to Asia Minor when he observed the destructive effect of the wars on funerary monuments; the stone may have been transported by ship to Syria-Palaestina and ended up on the antiquities market of Nazareth. [AC]

94) A. GIOVANNINI, "Un document amphictionique méconnu : la convention financière de Drymaia (IG IX 1, 226-230)", in T. HANTOS (ed.), Laurea internationalis. Festschrift für J. Bleicken zum 75. Geburtstag, Stuttgart. 2003, p. 287-297 [BE 2005, 246; SEG LIII 491]: A dossier of documents at Drymaia concerns the repayment of money owed by Drymaia to the Oitaioi and to a sanctuary (IG IX.1, 226-230, 2nd cent.). It has been generally assumed that the sanctuary in question was the federal sanctuary of the Oitaioi. G. argues, however, that $\pi \cup \lambda \alpha i \alpha$ (II 1-6) is always used in connection with the Delphic amphictyony and

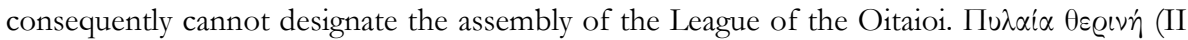

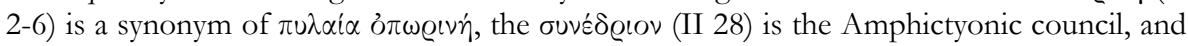


the creditor was the sanctuary of Apollon in Delphi. Debts were often given by sanctuaries to communities which participated in the cult (e.g., IG II ${ }^{2} 1635$; IG XI.4, 559). The debts in question are connected either with financial problems caused by the Second and Third Macedonian Wars or with the financial obligations of Drymaia when the Phokeis were reintegrated into the Amphictyony after the Third Macedonian War. [AC]

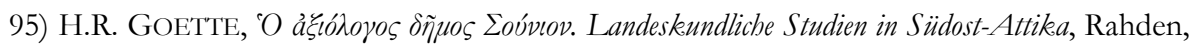
2000: In this study, the published version of a Habilitation thesis, G. attempts to present in c. 120 pages (p. 123-159 are a catalogue of the epigraphically attested demotai) an overview of processes of urbanisation and the economic and religious life in the deme of the Sounieis. [G. does not reveal in which ancient source he discovered the demotic "Sounieut" (plural "Sounieuten"!); he obviously does not realise that this nomen agentis means "those who do Sounian things']. A large part of chapter II is dedicated to the sanctuaries of Poseidon and Athena Sounias on the promontory (history, architectural setting, and sculpture) [G. ignores the invaluable first publication of the four kouroi from the sanctuary of Poseidon by K. Rhomaios, "Die Kuroi von Sunion", AntDenk IV, Berlin, 1931, p. 91-105]). In respect of the admittedly problematic inscription on a fragmentary thigh of a kouros found in the sanctuary of Athena recording a dedication of the Sounieis (6th cent.) G. repeats the restoration proposed by A. MATTHAIOU in $I G \mathrm{I}^{3} 1024$ (QON $\Delta \mathrm{I}_{F} \mathrm{~A}[\mathrm{P}] \mathrm{X}$ ), dismissing a connection with a dedication to Zeus Archegetes, as proposed for example by G.R.

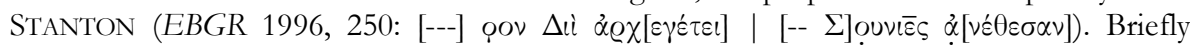
referring to three inscriptions from the fortress which refer to the cult of Asklepios Soter [SEG XVI 177, 2nd cent.] and Hygieia [SEG XVI 178, Imperial period], as well as to a temenos and a temple of Asklepios (IG II ${ }^{2}$ 1302, 222/1), G. repeats the assumption that a cult of Asklepios was founded at Sounion only in the late 3rd cent. [but J. RIETHMÜLLER, Asklepios. Heligtümer und Kulte, Heidelberg, 2005, vol. 2, p. 38-41, presents all the relevant material, including inscriptions not referred to by G., convincingly suggesting the existence of a sanctuary of Asklepios on Cape Sounion already in the late 4th cent.]. There is also a brief discussion of the inscriptions referring to the genos of the Salaminioi and its Herakleion, but without any new insights [see EBGR 2000, 120 for an interesting interpretation of the inscriptions of the Salaminioi and the location of their Herakleion (or Herakleia); see also infra no 161]. G. also deals briefly with the evidence for cults of Hermes and Artemis in the deme of Sounion (SEG XXVI 137, 226) [see also infra no 240]. [JM]

96) R. GORDON, "Ritual and Hierarchy in the Mysteries of Mithras", Antigüedad: Religiones y Sociedades 4 (2001) [2005], p. 245-274: Drawing upon iconographic and epigraphic material (in particular graffiti from Dura-Europos, dipinti from the Mithraeum of the Church of Santa Prisca in Rome, and the 'Schlangengefäß' from Mainz) G. convincingly defends the traditional view that there existed grades of initiates in the Mithraic mysteries (not a

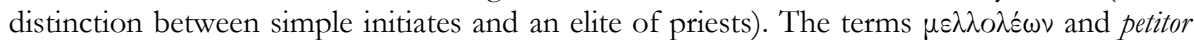
presuppose a progressive initiation; the grade Heliodromus is attested in the vase from Mainz (R.L. BECK, "Ritual, Myth, Doctrine, and Initiation in the Mysteries of Mithras: New

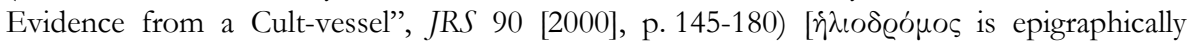
attested in a different context in Asia Minor, but probably under Mithraic influence; see SEG XLIII 943 and EBGR 2003, 71]. The language of the acclamations in Dura shows that

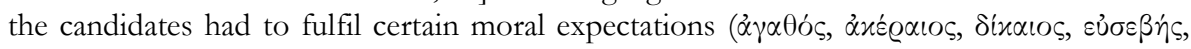

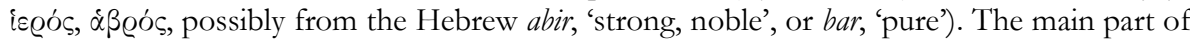
this study is dedicated to the question of how the hierarchical structure of the Mithraic communities and their rituals reproduced phenomena of contemporary society, especially relations of patronage. Patterns of hierarchy and subordintion were expressed through ritual performances ('liberation', abasement). [AC] 
97) R. GORDOn, “Another View of the Pergamon Divinatory Kit”, JRA 15 (2002), p. 188198 [BE 2003, 142]: Critically reviewing the interpretation of the objects in the 'Pergamon divinatory kit' as instruments of divination ( $c f$. infra $\mathrm{n}^{\circ} 183$ ) and exploiting the information contained in magical papyri, G. presents strong arguments against the view that the various objects in this assemblage were parts of a single divinatory kit. E.g., the disc may have been used for divinatory practices that aimed at inducing a trance by means of observation of an object (e.g., katoptromancy, lekanomancy). The triangular stand with the representation of Hekate should not be seen as connected with the disc but, as the evidence of the magical papyri suggests, may be associated with love spells and compulsive hymns. The other objects could have a variety of functions in magic and divination. The texts on the stand show that the author knew vaguely what a magical incantation should sound like but had no intimate knowledge of incantatory techniques. This assemblage, apparently property of an educated Greek open to occult practice and perhaps associated with the group of postIamblichan theurgists in Pergamon, provides evidence for the prestige of Graeco-Egyptian magic far beyond the sites where magicians were trained. $[\mathrm{AC}]$

98) R. GORDON, "Raising a Sceptre: Confession-Narratives from Lydia and Phrygia", JRA 17 (2004), p. 177-196: After presenting an overview of the 'confession inscriptions' of Lydia and Phrygia as texts and monuments, G. approaches these text from a sociological perspective. This fruitful approach allows him to detect in the narratives efforts to minimise social shame and to study how the narratives contributed to social negotiation within the communities (e.g., BIWK 10, 34, 44, 47, 59, 62, 76) [cf. supra nos 44-45]. G. rightly places a lot of emphasis on the narrative system of the texts (a fabula consisting of provocation of divine anger, punishment, anagnorisis, lysis) and the significance of the images. [A marginal remark:

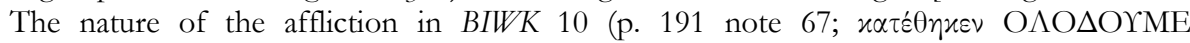

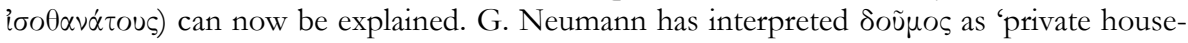
hold' (see infra $\mathrm{n}^{\circ}$ 197). One may now read $\delta \lambda o \delta o u \mu \varepsilon<i>=\pi \alpha \operatorname{voux}(\varepsilon) i$ ('the god put the

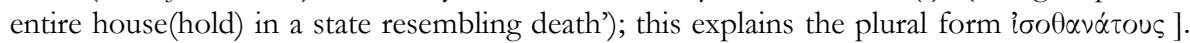
[AC]

99) R. Gordon, "Social Control in the Lydian and Phrygian 'Confession' Texts", in L. Hernández Guerra - J. Alvar EZQUerRa (eds.), Actas del XXVII Congreso Internacional Girea-Arys IX. 'Jerarquías religiosas y control social en el mundo antiguo', Valladolid, 7-9 de noviembre 2002, Valladolid, 2004, p. 193-203: G. stresses the great significance of the Lydian and Phrygian 'confession inscriptions' as a source of information for conflicts in rural communities and for the use of religion to reinforce social control (see esp. BIWK 3, 11, 37, 38, 50, 54, 60, 68) [cf. supra no 45 and infra no 294]. [AC]

100) Gorny \& Mosch, Giessener Münzhandlung. Auktion 137. Antike und islamische Kunst, Mittwoch, 15, Dezember 2004: The catalogue of antiquities offered for sale includes a carneol gem with

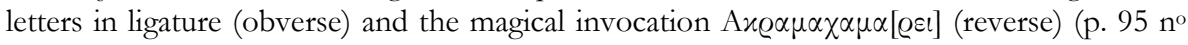
342, 2nd/3rd cent.). The dedications to Kakasbos and Hermes (129 n ${ }^{\text {os }} 486-488$ ) have already been presented in EBGR 2003, 61. A funerary relief has the formula sủ $\dot{i}^{\prime} \chi^{\prime}\left(129 \mathrm{n}^{\circ}\right.$ 489, unknown provenance, $2 \mathrm{nd} / 3 \mathrm{rd}$ cent.) [misread as sủ $\tau^{\prime} \chi \imath$ in the catalogue]. A bronze lamp from the Eastern Mediterranean (177 $\mathrm{n}^{\circ} 703$, early Imperial period) was dedicated to

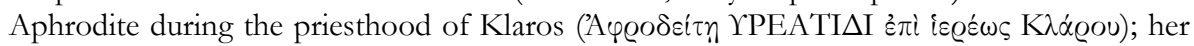
epithet is unattested and possibly misread]. [AC]

101) M.E. GORRINI, "Eroi salutari della Grecia continentale tra istanze politiche ed universali", Annali di Archeologia e Storia Antica NS 9/10 (2002/03), p. 163-196: This study, originally a tesi di Dottorato, presents a useful panorama of the cult of healing heroes in Greece, based on data from 187 cult sites (119 of them for Asklepios, whom she includes in 
the category of healing heroes, the others for heroes such as Machaon, Podaleirios, Amphiaraos, Trophonios, Chiron, Korythos, Hyperteleatas, and Maleatas). G. discusses the rituals connected with these cults, in particular the $\pi \varrho 0 \theta v \sigma i \alpha$ and the joint cult of healing

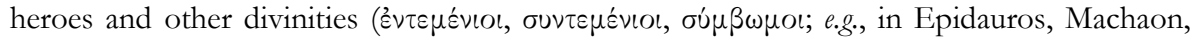
Podaleirios, Danae, Artemis, Agathos Daimon, Agathe Tyche, Iatros, Ammon, Poseidon, Megale Meter, Tyche-Nemesis, Pan, Herakles; in Kamiros, Artemis Epimelidios, Zeus Machaneus, Poseidon Phytalmios, Dionysos Epikarpios, Zeus Drouthios, Amphilochos, Presbytas, Zeus Astrapaios, Hestia); the practice of incubation; the close involvement of young men in these cults; the dedicatory practices (anatomical votives, statues, pottery, weapons); and the important features of the sanctuaries (e.g., existence of water, incubation rooms). G. attributes to the Asklepieion of Epidauros a leading role in the dissemination of the cult of Asklepios [but J. RieTHMÜLLER, Asklepios. Heiligtümer und Kulte I, Heidelberg, 2005, p. 37-39, 91-106, has recently presented strong evidence in favor of a Thessalian origin for Asklepios' cult; cf. infra $\mathrm{n}^{\circ}$ 288; on healing heroes see also supra $\mathrm{n}^{\circ} 26$ and infra $\mathrm{n}^{\circ}$ 249]. She also demonstrates that despite the private nature of this worship, these cults were under the control or supervision of the polis (e.g., as regards the appointment of priests), as the history of the cult of Asklepios in Athens shows. [JM]

102) P. Goukowsky, "Sur une épigramme de Thespies", in L'épigramme, p. 217-246: G. presents a penetrating analysis of the epigram dedicated by Hadrian to Eros in Thespiai (AD 134 rather than $\mathrm{AD} 125$; IG VII 1828), placing it in the context of the deification of Antinoos and the philosophical and religious ideas of Hadrian. A hymn for Antinoos from Kourion (I.Kourion 104), for which G. suggests several restorations (line 3: $\pi[\alpha \tilde{\imath} \varphi \lambda \circ \gamma] \tilde{\omega} \pi \alpha$;

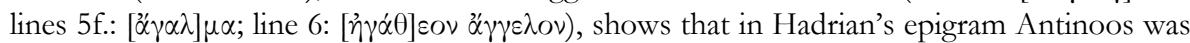
identified with Eros. The offering of a hunting trophy to Eros, the hunter, alludes to the hunting activities of Hadrian and Antinoos. In a first level, the epigram requests that Eros, the son of the wind Zephyros, asks Aphrodite, a patron of seafaring, to grant a safe journey

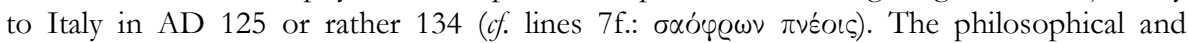
theological background of the poem is, however, more complex. Aphrodite (line 1: $\lambda$ i $\gamma \varepsilon i \eta$; line 8: ov̉@ $\alpha v^{\prime} \alpha$ ) was conceived as a patron of celestial harmony, related to Platonic ideas and to the concept of felicitas temporum. Eros/Antinoos, who resides near the garden of Narkissos and who is characterised as 'chaste' (line 7: $\sigma \alpha o ́ \varphi \varrho \omega \nu$ ), is asked to serve as an intermediary

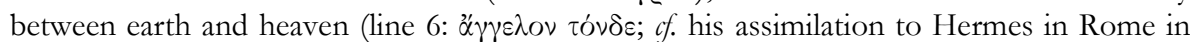
IGUR 143). [The belief in intermediaries between a superior god and the mortals is widespread in the religiosity of the Imperial period; see, e.g., the theosophical oracle from

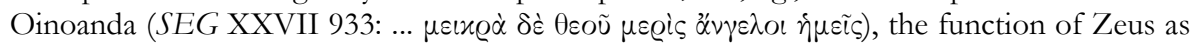
$\pi \alpha \varrho \alpha \dot{x} \lambda \eta \tau \tau$ of a sinner, representing him in front of Mes in a confession inscription (BIWK 5), and a dedication to Janus at Colle Maiorana in Latium (AE 1996, 370: et faciles aditus da Iovis as speciem; "and grant an easy approach to the presence of Jupiter")]. G. discusses in detail the philosophical concepts connected with Eros as well as the apotheosis of Antinoos and his mystery cult in Mantineia and Bithynion (cf. IGR III which mentions a $\theta u \dot{\eta} x o o \varsigma \tau \tilde{\omega} \nu$ $\mu \nu \sigma \tau \eta \varrho^{i} \omega \nu$ and a $\left.\mu \nu \sigma \tau \dot{\alpha} \varrho \chi \eta \varsigma\right)$. Mantineia may have been selected as the seat of the mysteries

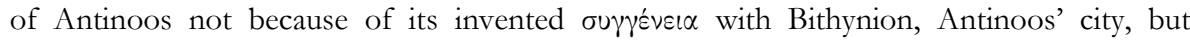
because of its relation to Antinoe (Paus. VIII, 8, 4-5) and to Diotima. G. reprints an honorary epigram for Isochrysos (IG V.2, 312, Mantineia), identifying the dedicant Epitynchanos as Hadrian's freedman (Marcus Aurelius, ep. 8.25), and inferring from the wording that

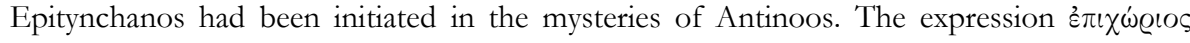

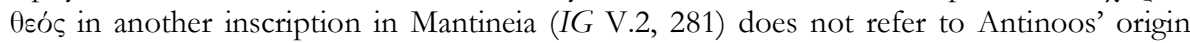
from Bithynion but to the fact that Antinoos was believed to be near his sanctuary. [AC] 
103) C. HABICHT, "Ein neuer Gymnasiarch am Fest der Athena Ilias", EA 37 (2004), p. 91 94 [BE 2005, 394]: A decree from Ilion honours the gymnasiarch Antikles from Lampsakos for his work during the festival of Athena Ilias (cf. EBGR 2003, 121; c. 150-100). An earlier decree, also from Ilion, honours for the same reason the gymnasiarch Kydimos from Abydos (I.Ilion 2; c. 230-200). A comparison of the two decrees shows that Kydimos had

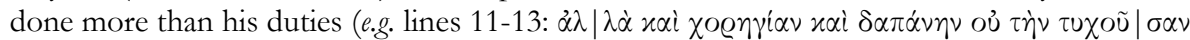

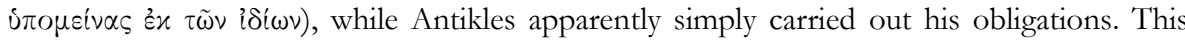
difference is reflected in the manner in which the two gymnasiarchs were honoured: both received a gold crown and a bronze statue, but only Kydimos became proxenos and euergetes of the festival and received the privilege of prohedria during the festival and

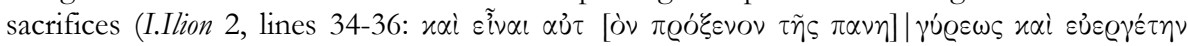

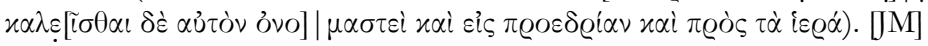

104) K. Hallof, Inscriptiones Graecae Insularum Maris Aegaei praeter Delum. Fasciculus VI. Inscriptiones Chii et Sami cum Corassiis Icariaque. Pars II. Inscriptiones Sami Insulae. Dedicationes. Tituli Sepulcrales. Tituli Christiani, Byzantini, Iudaei. Varia. Tituli graphio incisi. Incerta. Tituli alieni. Inscriptiones Corassiarum edidit Klaus Hallof. Inscriptiones Icariae Insulae edidit Angelus P. Matthaiou, Berlin, 2003 [SEG LIII 877, 888-906]. The second volume of the Samian corpus presents inscriptions from Samos, Korassia, and Ikaria. Samos: The majority of the texts are dedications, most of them found in the Heraion (537-556). We record only the most interesting features. Naturally, most of the texts of a religious nature refer to the cult of Hera. A bronze rhyton records in addition to the names of the dedicants the greeting $\chi \alpha$ i $\varrho$, $\tilde{\omega}$ i $\varrho \varepsilon \tilde{u}(538,6$ th cent.). № 542 is a joint dedication to Hera and Poseidon Epakrios (6th cent.), no 610 to Hera Archegetis and the emperors of the tetrarchy (610, 308-311 AD).

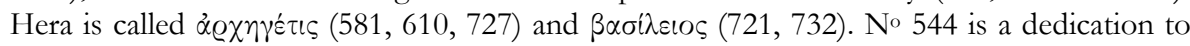

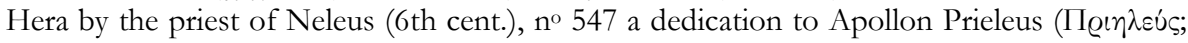

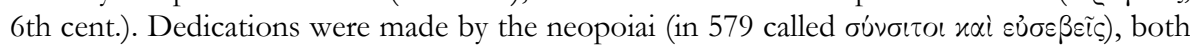

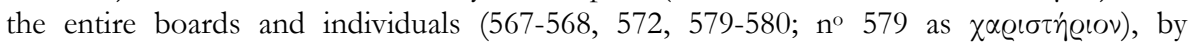
panegyriarchoi (582), the emperor Commodus (583), and governors (584-585, 4th cent. AD). Hera Samia, Trajan, and the Demos were recipients of a joint dedication (571). A

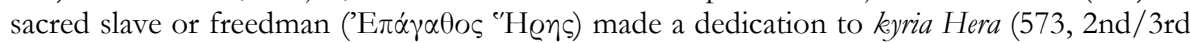
cent.). Epigrams were dedicated to Hera by governors of the provincia Insularum in Late Antiquity (574-585, 4th cent. AD). There are three Latin dedications to Iupiter Optimus, Iuno, and Hercules (605-607). Other texts related to the sanctuary of Hera refer to the construction of a neopoieion (578, Hellenistic) and the use of bronze and stone weights (966, 968). A torch-race at the Heraia is mentioned in no 1004. Besides Hera, dedications were addressed to the following gods: Aphrodite (595; an anatomical votive; 598, 609*), Apollon (586, 589; no. 614 in Delphi), Apollon Pythios (608), Dionysos [D]allios (603), Eleutheros (Zeus or Eros: 587), Hermes (611), Hermes Eisagogos and Aphrodite Synarchis (597), Meter Epikrateia (596, by a theophoros, i.e., the bearer of images of gods during processions; 2nd cent.), Poseidon (?, 612), Zeus Meilichios (602), the Egyptian gods (591, 600 by a

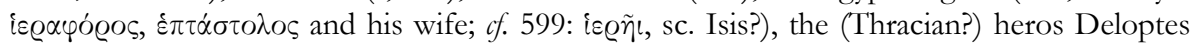
(592), the river Imbrassos, Parthenie (Samos?, Hera?, a founding heroine?), and Parthenios

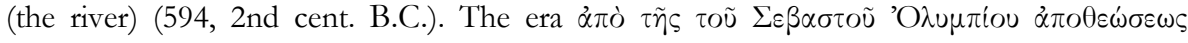
began from the death of Augustus (598). Statues of Nemesis and another divinity were

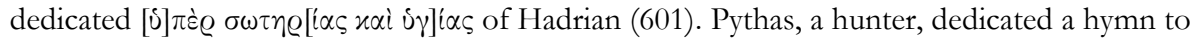

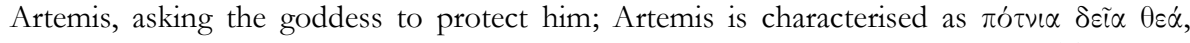

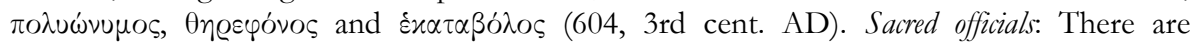
references to a priest of Her[a] [or Herakles] (860), a high priestess of the emperor cult $\left(1144^{*}\right)$, a hieros of the Heraion (688), and a hiera (756). A funerary relief was used for the 
grave of three hieroi and two hierai $\left(803^{*}\right.$, 2nd cent. AD). Funerary cult: The deceased persons are called heros/heroine (688, 690-694, 696-697, 699, 702, 706-707, 712, 714, 718, 725, 731, 736-739, 741, 742-745, 747-749, 753-757, 764, 766-767, 769-770, 772-779, 782784, 786-787, 792, 799, 800-806, 815, 817-826, 829, 832-837, 839, 841, 851, 856-861, 863$867,870,874,876,878,880,886)$. We also note a funerary imprecation $(709,1$ st cent. AD:

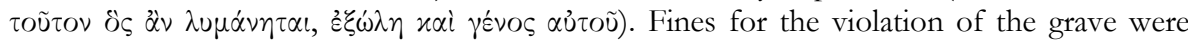
paid to the sanctuary of Hera $(721,727,732)$. An epitaph uses the expression $\theta$ eois $x \alpha \tau \alpha \chi$ Ooviors (730). In a funerary epigram (740, 2nd cent.), Minos, the judge in the underworld, is asked to place the deceased man among the pious (

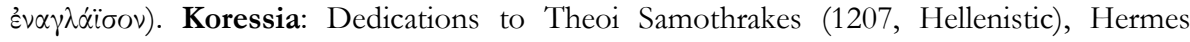
(1208, Hellenistic), the Nymphs (1209, 2nd/3rd cent.; by a man called Nymphios) [his name suggests a personal devotion to the Nymphs; for this phenomenon $c f$. W.R. CONNOR, "Seized by the Nymphs: Nympholepsy and symbolic expression in classical Greece", ClAnt 7 (1988), p. 155-189], and to an anonymous deity (1207). Ikaria: In addition to the texts mentioned infra $\mathrm{n}^{\circ} 189$ and re-edited in the corpus, the corpus includes two dedications to emperors $(1219,1223)$ and graffiti on vases dedicated to Artemis Tauropolos (1282-1284). [AC]

105) P. HAMON, "Les prêtres du culte royal dans la capitale des Attalides : note sur le décret de Pergame en l'honneur du roi Attale III (OGIS 332)", Chiron 34 (2004), p. 169-185 [BE 2005, 397]: One of the most important Pergamene decrees (OGIS 332) regulates inter alia the cultic honours for Attalos III in a very detailed manner. After a victorious military campaign, the king returned to Pergamon and entered the capital city in two distinct chronological stages. During the first stage the king arrived at the grove of Asklepios and received cultic honours in the form of the erection of his a statue in the Asklepieion; this transformed the sanctuary into a cult place for Asklepios and the king. A priesthood of

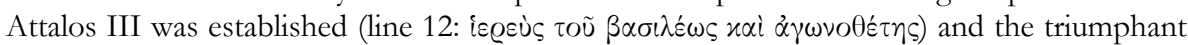
return of the king was to be celebrated every year through a commemorative festival in the Asklepieion. In the second stage, Attalos III entered the city. Upon his arrival all the temples were opened, each tribe sacrificed in honour of the king, sacrifices took place in the agora of the city, and the king was invited to a banquet in the prytaneion. H. convincingly argues that these honours inside the city of Pergamon were not to be repeated in the future on every single return of the king to the city, as suggested by B. Virgilio, but were a single, non-recurring accumulation of honours. H.'s restoration of lines 26f. solves the problem of the unparalleled existence of a group of stephanophoroi for the Twelve Gods and Eumenes

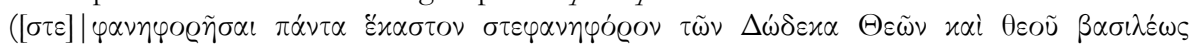
Eủévou). According to the new reading the text prescribes a stephanephoria of the entire

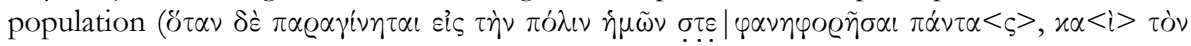

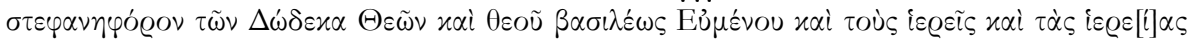

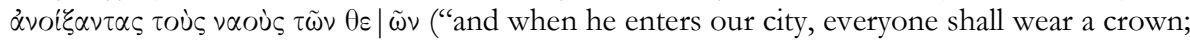
and the stephanephoros of the Twelve Gods and of the god king Eumenes, the priests, and the priestesses shall open the temples of the gods). Despite the fact that priestly offices are known for Philetairos, Attalos I, Eumenes II, Attalos II, Apollonis, Stratonikeia, and Attalos III, there is no attestation of a high priest in the Pergamene kingdom. H. argues that the essential difference between Attalid ruler cult and that of the Seleucids and Ptolemies was the conception of the cultic honours bestowed as a civic and not a state cult. [JM]

106) M. Hatzopoulos, "La société provinciale de Macédoine sous l'Empire à la lumière des inscriptions du sanctuaire de Leukopetra", in L'bellénisme d'époque romaine, p. 45-53: According to the epigraphic and numismatic evidence, the sanctuary of Meter Theon Autochthon in the territory of Beroia must have been founded under Antoninus Pius. The 
latest coins belong to the reign of Arcadius. All the inscriptions found in the sanctuary (c. 200 texts) are in Greek. Most of them document the dedication of slaves (EBGR 2000, 155). A comparison between contemporary inscriptions from the sanctuary and from Beroia reveals that only two persons appear in both epigraphic assemblages. H. suspects that they may have been priests of Meter Theon Autochthon. [JM]

107) M.B. Hatzopoulos - M. Mari, “Dion et Dodone”, in L'Illyrie IV, p. 505-513 [BE 2005, 313]: A comparative analysis of the history of the sanctuaries of Zeus in Dion and Dodona reveals striking similarities. Both sanctuaries seem to owe their importance to their position on routes of transhumant shepherds [for this phenomenon of. EBGR 2003, 73 and 181]; the urban centre was in both cases of secondary importance; both sanctuaries were to benefit from building projects included in the last plans of Alexander the Great; both were plundered by the Aitolians; in the periods of their greatest importance both sanctuaries served as 'national' sanctuaries of the Macedonians and the Epirotans respectively and had great significance for the identity and self-representation of these ethne and as meeting places; but while the festival of the Naia in Dodona acquired a Panhellenic status in the Hellenistic period, the Olympia of Dion remained a local Macedonian festival. [AC]

108) B. Helly, "Décrets de cités thessaliennes à Cos", Chiron 34 (2004), p. 87-107: H. discusses inter alia the three decrees of Thessalian cities recognizing the asylia of the Koan Asklepieion (RIGSBY, Asylia 19-22 and SEG LIII 850-851; cf. EBGR 2003, 18). He argues that the reference to an epistates in the decree of Homolion shows that the coastal Magnesian cities were under Macedonian control by the mid-3rd cent. [but see the comments in SEG LIII 850]. H. convincingly argues that the decrees of Homolion and Gonnoi do not refer to

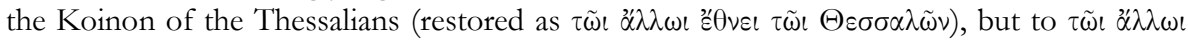

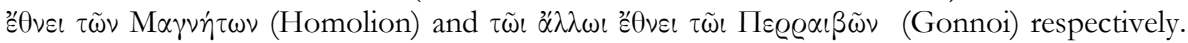
$\mathrm{H}$. also discusses the fragmentary Koan decree referring to Koan theoroi visiting the federal sanctuary of Athena Itonia [see the new edition by K. RIGSBY, infra no 230]. As regards the decree of a Thessalian city recognizing the asylia of the sanctuary of Artemis Leukophryene in Magnesia on the Maeander (I.Magnesia 26), H. suggests that the statue of the king referred

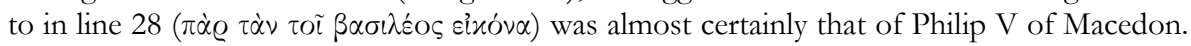
[JM]

109) A. HeLmis, "Entre les vivants et les morts. La fondation à la mémoire d'Aleximachos fils de Critolaos (IG XII.7, 515, II siècle av. J.-C.)", in G. THÜR - F.J. FERNÁNDEZ NIETO (eds.), Symposion 1999. Vorträge zur griechischen und hellenistischen Rechtsgeschichte (Paحo de Mriñán, La Coruña, 6.-9. September 1999), Cologne, 2003, p. 463-480 [SEG LIII 906bis]: The foundation of Kritolaos for the commemoration of his deceased son Aleximachos (Aigiale, ca. $100 \mathrm{BC}$; IG XII.7, 515) presents an interesting case of how a private initiative (the funerary foundation of Kritolaos) became subject to public control by means of a decree that regulated the management of the money and the organisation of the sacrifice, the banquet, and the contests in the gymnasion; thus the heroised Aleximachos became part of the social memory of the entire community. H. discusses inter alia how the foundation of Kritolaos was assimilated to 'sacred money' (line 19), the heroisation by means of a decree (cf. IG XII.3, 281, 288, 864-883, and 885), and the rituals of the heroic cult. H. rightly assumes that the statue $\left(\alpha^{\prime} \gamma \alpha \lambda \mu \alpha\right)$ of Aleximachos, in front of which a sacrifice was offered, was placed in the gymnasion (p. 477). [For further examples see supra $\mathrm{n}^{\circ} 26$ and infra $\mathrm{n}^{\circ} 298$. One should note here the intentional selection of ambigious vocabulary (lines 75f.):

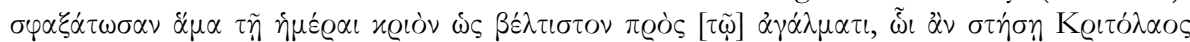

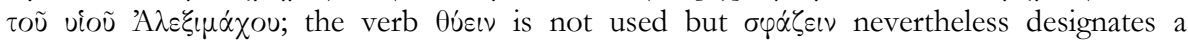
sacrifice $(c f . \sigma \varphi \alpha \dot{\alpha} \gamma(\alpha)$; the recipient of the sacrifice (e.g. 'A $\lambda \varepsilon \xi \iota \mu \alpha \chi \omega)$ is not mentioned but the 
place of the sacrifice (towards/near the 'cult statue' of Aleximachos) and the use of the term $\ddot{\alpha} \gamma \alpha \lambda \mu \alpha$ indicate that it was Aleximachos (the same statue is referred to as an $\alpha \dot{\nu} \delta \varrho \alpha^{\prime} \alpha$ in line 134 , in a non-religious context; the ambiguous vocabulary reflects the ambiguous status of the heroised person]. [AC]

110) W.B. Henry, "Two Verse Inscriptions (I.Oropos 675, SEG 49.1976)", ZPE 145 (2003), p. 10-12 [SEG LIII 467]: H. recognises a reference to Zeus Hetaireios in a grave

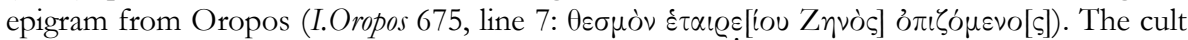
is not attested in inscriptions ( $c f$. Herod. I, 44, 2). [AC]

111) P. Herrmann, "Apollon de Pleura. Un sanctuaire rural en Lydie entre les époques hellénistiques et romaine", in L'bellénisme d'époque romaine, p. 277-286: An important inscription documenting the existence of a sanctuary of Apollon Pleurenos in the district called Gygaia Limne was originally dated by L. Robert to either 26/5 or 23/2 BC (SEG XXXII 1237). The study of two recent finds which refer to this sanctuary (SEG XLVI 1519-1520) leads $H$. to a different interpretation of the whole dossier. SEG XLVI 1519 refers to the high priest Nikanor and the Seleucid king Antiochos III and should be dated between 202 and 196 BC. The second inscription (SEG XLVI 1520) is later (after 129 BC, probably early 1 st cent.) since it is dated with reference to the eponymous priests of Sardeis (the priests of Rome and Zeus Polieus). H. dates SEG XXXII 1237 to the reign of Attalos II, (probably 150/49 BC). Thus these three inscriptions document the changes the sanctuary of Apollon Pleurenos underwent under Seleucid, Attalid, and Sardian control. [JM]

112) P. HerZ, "Zur Geschichte des Kaiserkultes in Kleinasien. Die Kultorganisation für die cives Romani”, in Religionsgeschichte Kleinasiens, p. 133-148: According to Dio Cassius (LI, 20, 6), the Roman citizens in Ephesos and Nikaia were instructed to establish a cult of Dea Roma and Divus Iulius. Due to the parallel establishment of the provincial emperor cult, the participation of enfranchised Greeks - possiblly also of old Roman citzens - in the provincial cult and their service as high priests (e.g., I.Sardis 8: M. Antonius Lepidus; SEG XLIV 938: C. Iulius Epikrates) resulted in the disappearance of this separate cult. The

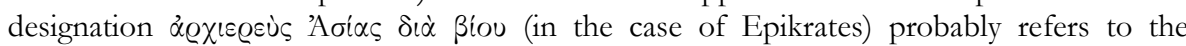
expenses of the emperor cult and not to a lifelong priesthood. [AC]

113) C. HigBIE, The Lindian Chronicle and the Greek Creation of their Past, Oxford, 2003 [SEG LIII 821]: The 'Lindian Anagraphe' (I.Lindos 2) has attracted relatively little attention despite its enormous significance both for Greek religion and Greek historical memory. The book of $\mathrm{H}$. is, therefore, very welcome, since it presents a critical edition, translation [for several mistakes see SEG LIII 821], and a thorough commentary on the mythical and historical traditions connected with the dedications to Athena and the miracles of Athena Lindia. In the systematic analysis of this text $\mathrm{H}$. discusses inter alia the identity of the donors, the types of the dedications, and the dedicatory inscriptions, the epiphanies of Athena, and parallels for the epiphanies (esp. IOSPE I² 344). [AC]

114) G. Hirsch, Antiken, prekolumbianische Kunst. Auktion 235 (21 und 22. September 2003), Munich, 2004: A revetment plaque of a grave (p. $9 \mathrm{n}^{\circ} 354$, unknown provenance, $2 \mathrm{nd} / 3 \mathrm{rd}$ cent.) was offered for sale [information and text provided to us by W. Günther]. The

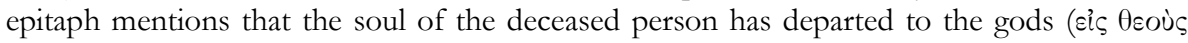

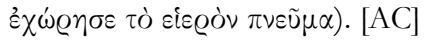

115) R. HоDOT, "Langue, identité et représentations dans le domaine étolien d'Asie", in L'bellénisme d'époque romaine, p. 247-254: During the Late Hellenistic and Early Imperial period most cities of the Eastern Aeolic area predominantly used the koine in their inscriptions. The Aeolic dialect appears only in a few types of inscriptions, almost exclusively 
related to the public sphere. An interesting example is offered by two inscriptions from Mytilene (IG XII.2, 108-109, 1st cent. AD) recording the dedication of a bronze statue to Artemis: H. suggests that these two inscriptions belong to a single document, with one part in dialect and one in the koine. [JM]

116) G.H.R. HORSLEY, "Homer in Pisidia: Aspects of the History of Greek Education in a Remote Roman Province", Antichthon 34 (2000) [2001], p. 46-81: In a study dedicated to Homeric resonances in Pisidian inscriptions, H. discusses inter alia the epigram of Euarestos in Oinoanda referring to the foundation of an agonistic festival (p. 59-61), the honorary epigram for the poet Chrysippos the so-called Panages, who founded a sanctuary of Artemis and sung hymns for her (I.Pis.Cen. 32), and the dedicatory epigrams for Mes from Kibyra (EBGR 1997, 177). He also publishes a new epigram, perhaps referring to a Christian

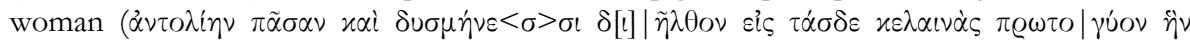
$\tau \varepsilon i ́ \mu \eta \sigma^{\prime} \delta$ o $\theta \varepsilon \dot{\varsigma} \mid \pi \lambda \dot{\eta} \theta u v \varepsilon \delta \dot{\varepsilon} \pi i \sigma \tau \varepsilon i$; "I went through all of the East and among enemies to these black (roads?), I whom first of all God honoured and made abound because of/by my faith"; p. 71-72, late 3rd cent. AD, Burdur Museum). [AC]

117) A. INGLESE, "Due iscrizioni ateniesi dal Portico di Eumene", PP 57 (2002), p. 231-236 [BE 2004, 131; SEG LII 141]: I. presents in majuscules the text on a stone fragment, inscribed on both sides, found in the Stoa of Eumenes (Athens; p. 233-236). [As is noted in SEG LII 141, this text (an inventory of the Asklepieion) is not new; see SEG XXXIX 166 and EBGR 1991, 3]. [AC]

118) B. IPLIKÇIOGLU, "Doğu ve kuzeydoğu Lykia-güneybati Pisidia epigrafik-tarihî coğrafi yüzey araştirmalari projesi 2000 yili çalişmalari” AST 19.2 (2001), p. 127-132 [BE 2003, 500; SEG LII 1404-1410, 1440-1444]: Ed. pr. of dedications to Ares (13-19, Attaleia, Imperial period) and the river god Potamos Meizoares (20-24 Mnara, Imperial period). The dedications were made by individuals $(13-15,17,21-24)$ and groups of friends $(16,18,20$ : oi

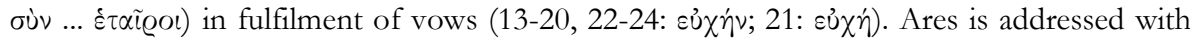
the epikleseis Megas (17) and Megas epekoos (13-14), Mizoares with the epiklesis Theos (20) and Sozon (23) [for similar dedications see infra no 119]. [AC]

119) B. IplikÇIOGLU, "Bati Pamfilya ve Doğu Likya'da epigrafya araştirmalari 2001", AST 20.2 (2002), p. 71-75 [SEG 1642-1647, 1653-1668, 1683]: Ed. pr. of numerous dedications to Kakasbos, the Dioskouroi, and Ares found in Lykia. 16 dedications to the local god Kakasbos were found in the area of Elmalı (undated). The name of the god is given in different forms, as Kakasbeus (2), Kyrsas (1, 3-4, 7-8, 13), Kyrsas Theos (12, 14), Kyrsas Theos Kakasbeus (5), and Kakasbeus Kyrsas (9-10). The dedications were made in

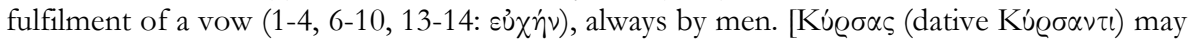

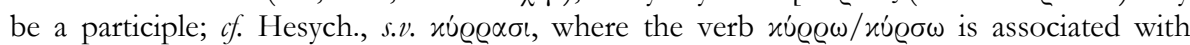

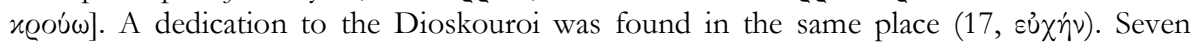
dedications to Ares were found in northeastern Lykia (undated). They were made in

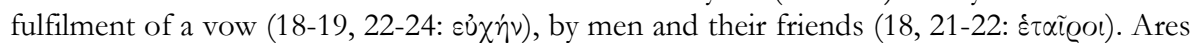
is called Megas (22) and Megas Epekoos (24) [cf. supra no 118]. A dedication in Mnara was

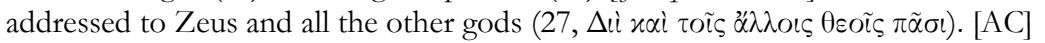

120) B. IPLIKÇIOGLU, "Bati Pamphylia ve Dogu Lykia'da epigrafya Arastirmalari 2002", AST 21.1 (2003), p. 75-78 [BE 2005, 474]: Ed. pr. of a stele with the formulation $\Theta \varepsilon o$ is

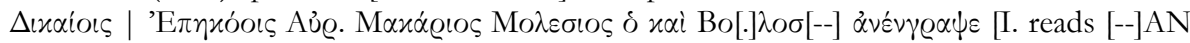

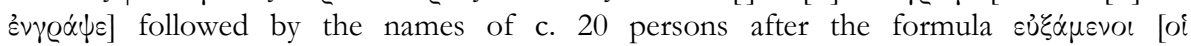

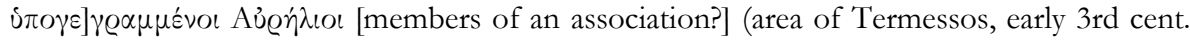
AD). A second dedication to the same gods is written on a stele. The text is metrical, but 


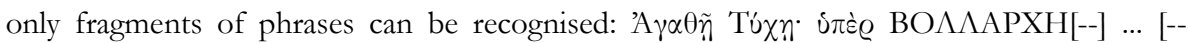

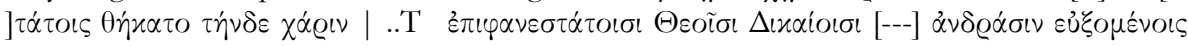

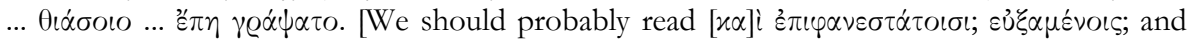
$\varepsilon \pi \gamma \varrho \alpha \psi \alpha \tau o$; the text refers to the setting up of an inscription with the names of the members of a cult association; on the cult of Theoi Dikaioi see supra no 50]. [AC]

121) A.S. IVANTCHIK, "Dedication to the Goddess Ma from Olbia (I.Olb 74)", ACSS 10.1/2 (2004), p. 1-14: J. identifies the dedicant of a fragmentary dedication in Olbia, Stephanos, son of Alexandros, (I.Olbia 74, c. 100 BC), with a man from Smyrna mentioned in an unpublished decree. This enables him to restore the text as a dedication to $\mathrm{Ma}$ and other

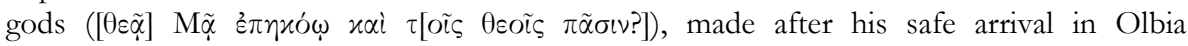

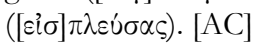

122) S. JAPP, "Zeugnisse jüdischen Lebens im antiken Pergamon und im neuzeitlichen Bergama", MDAI(I) 54 (2004), p. 257-265: In a collection of testimonia for the Jewish community in Pergamon (from the 1st cent. BC onwards, possibly already in the Hellenistic period), J. republishes a dedication (M.P. NILSSON, "Zwei Altäre aus Pergamon", Eranos 54

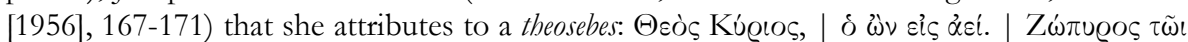

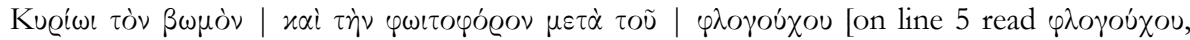
not $\theta \lambda$ oyoúxou. The acclamation in the first lines does not praise the god as "der Eine und Einzige" (p. 260) but as an eternal god. For this text see now W. AMELING, infra no 4, p. 305 note 5 , who rightly points out that it should rather be attributed to a worshipper of Theos Hypsistos; for the part played by lamps in the cult of Theos Hypsistos see EBGR 2003, 51]. [AC]

123) S. JiLEK, "Die Metall- und Beinfunde", in C. LANG-Aigner et al., Das Hanghaus I in Ephesos. Funde und Ausstattung, Vienna, 2003, p. 253-312 [SEG LIII 1288 ter]: Ed. pr. of a bronze bell with a fragmentary inscription [that seems to name Asklepios] found in Hanghaus I in Ephesos (272 and 310 no. B313). [AC]

124) C.P. JONES, 'Epigraphica IV-V', ZPE 142 (2003), p. 127-133 [SEG LI 1837]: In a study dedicated to the sophist Hermokrates of Phokaia (p. 127-130), J. argues that L. Flavius Hermokrates, who was honoured in Pergamon (SGO I 06/02/03), was an earlier relative, active in the second half of the 2nd cent. AD. The oracle written on the side of the monument in honour of this Hermokrates reads: "Oracle on Hermokrates from the great god Asklepios. He was not immortal, being mortal born, but long ago he alone was the best of hero-men". This oracle was probably given to admirers of Hermokrates who enquired about the fate of his soul after death; the god responded that in a previous life the philosopher had been the best hero (Achilles?), thus subscribing to a doctrine of reincarnation, comparable to the contemporary doctrine connected with the cult of Glykon Neos Asklepios in Abonou Teichos ( $c f$. Luc., Alex. 34 and 43). The unusual metrical form of the oracle may be compared with the theion epigramma sent by Asklepios to Aelius Aristides (Or. $\mathrm{L}, 45)$. In the same article (131-133), J. presents an improved edition of the epitaph of M. Aurelius Torquatus at Trebenna (SEG LI 1837; cf. EBGR 2001, 82), identifying him with a homonymous orator of the late 3rd cent. AD ( $A E$ 1915, 53). J. discusses the funerary cult established by Leon Torquatus (comments on the term vó

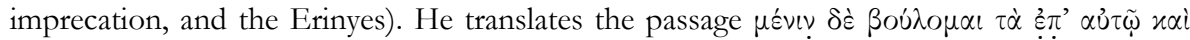

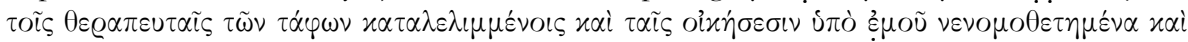

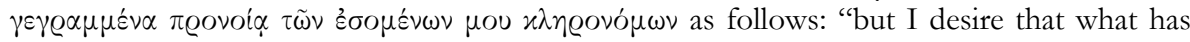
been ordained and written by me concerning it and those who have been left as cultassociates of the tombs and concerning the dwellings shall remain valid by the foresight of

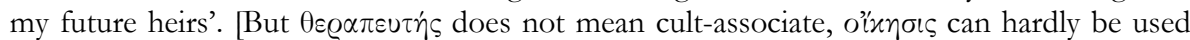


in connection with funerary monuments, and the passage suggests that the therapeutai (attendands) were not the same as the hairs ( $x \lambda$ neovó $\mu o r)$. J.'s interpretation is based on the

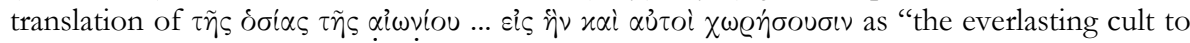
which they too shall succeed"; for my different understanding of this passage ("I wish that what I have regulated and written with regard to the grave and with regard to the things which have been left to those who take care of the grave and with regard to the dwellings will remain valid under the care of my future heirs") see EBGR 2001, 82. There is another

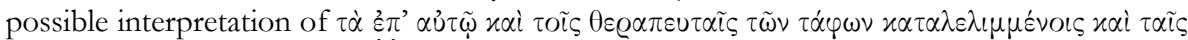
oixं $\sigma \varepsilon \sigma l v:$ "concerning it and those that I have left as attendants to the graves and the dwellings"; according to this interpretation, Torquatus manumitted slaves and/or gave them dwellings, on condition that they should take care of the grave; for this phenomenon $f$. supra $\left.\mathrm{n}^{\circ} 1\right]$. [AC]

125) C.P. JONES, "Epigraphica VIII-IX”, ZPE 146 (2004), p. 95-98: A number of epigrams composed by the Corinthian epigrammatist Honestus were engraved on blocks that formed part of an exhedra in the sanctuary of the Muses at Thespiai. One of them honours Livia as an Augusta who boasts two sceptred Gods (Augustus and Tiberius), has illuminated the lights of peace, and has saved the entire world through her wisdom (BE 1955, 119). J. demonstrates that the reason why a number of poems by Honestus have survived on stone in the sanctuary of the Muses could have been the close connections between Corinth and Thespiai. In the second part of his article J. demonstrates that the author of a poem honouring Asklepios found in the Asklepieion of Pergamon (MERKELBACH-STAUBER, SGO I, 06/02/16) must have been Aelius Aristeides, as already suggested by R. Herzog. [JM]

126) L. JONNES, The Inscriptions of Sultan Daği I (Philomelion, Thymbrion/Hadrianopolis, Tyraion), Bonn, 2002 (IGSK, 62): This corpus contains c. 550 inscriptions found in cities on the east slope of Mt. Sultan Daği (Phrygia); in an appendix, J. also presents the published inscriptions of Neapolis. [The ed. does not provide dates, simply stating (p. viii) that most texts date from the $3 \mathrm{rd}$ cent. AD and later]. Philomelion: Dedications: The most interesting dedication is a base decorated with a bust (Zeus Bennios?) and inscribed with a text addressed to Zeus Zemeiastes (*93), probably conceived as a patron of rain and fertility ( $c$. line 17: $\ddot{\varepsilon} \varepsilon$ ). [The fragmentary text is a prayer (certainly metrical), to judge from the

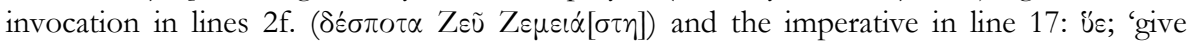

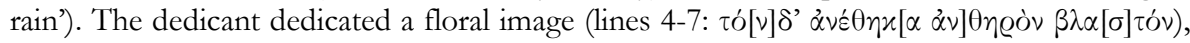
seemingly in order to avert destructive powers ( $c$. line 14: $\delta \eta \lambda \dot{\eta} \tau o \varrho[\alpha \varsigma])$, appealed to benevolent gods (line 15: $\left.[\theta \varepsilon] \circ \dot{s} \varsigma \mu \varepsilon i \lambda \varepsilon\left[\chi^{i}\right] \circ[\cup \varsigma]\right)$ and requested rain in response to a sacrifice (lines

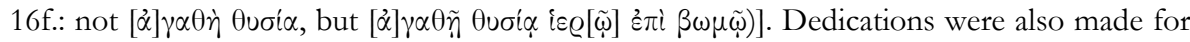

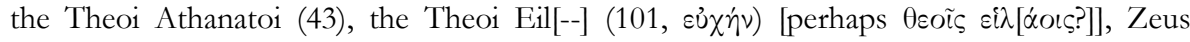

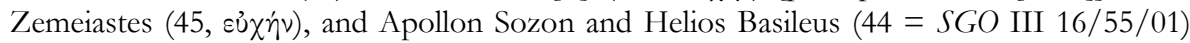

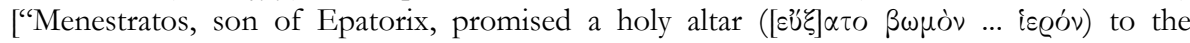

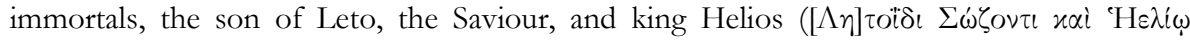
$\beta \alpha \sigma \iota \lambda \tilde{\eta} \iota$... $\dot{\alpha} \theta \alpha \nu \dot{\alpha} \tau \sigma \iota \sigma \iota)$; after he had been saved, he set it up for 'the most just and holy gods'

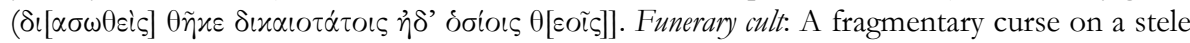

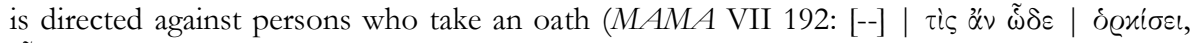

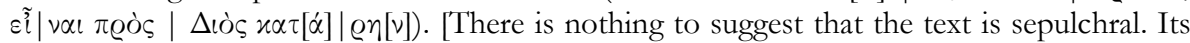
closest parallels are 'confession inscriptions' that criticise oaths and perjury; e.g. BIWK 27:

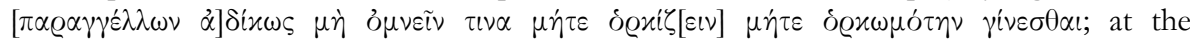

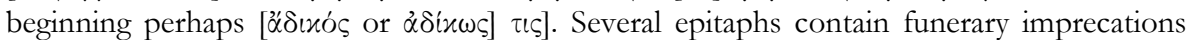
(*64 is fragmentary). The funerary epigram for a woman who died in childbirth $(1=S G O$

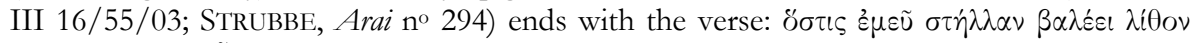

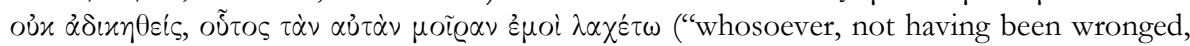


shall remove a stone at this stele, may be allotted the same fate as mine") [for oủ $\alpha \dot{\alpha} \delta \varkappa \eta \theta \varepsilon i c$ cf. a curse in Oropos (I.Oropos 745a = SEG XLVII $510=$ EBGR 1997, 296): $\alpha \xi i \tilde{\omega} \iota$ oũv

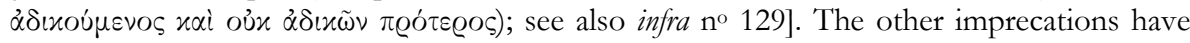

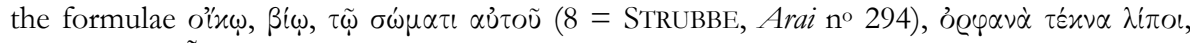

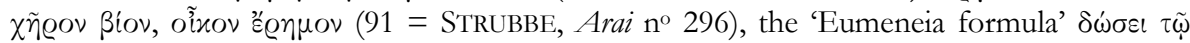

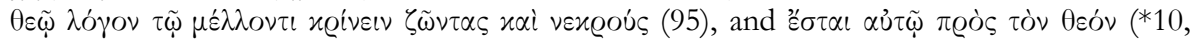

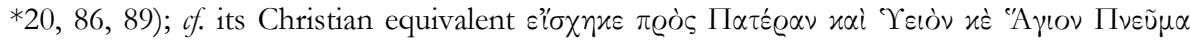
( $* 50$, ca. 4 th/5th cent.) and Thymbrion/Hadrianopolis: Dedications: to Theos Megistos Herakles (260), Hosioi kai Dikaioi (231, an altar, dedicated by the community under the

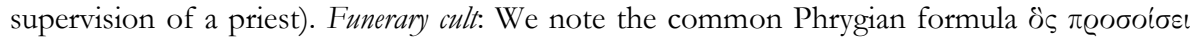

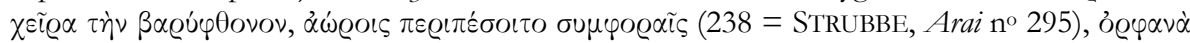

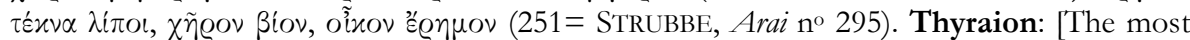
interesting text, edited with no comment, records the dedication of a threptos to a god: $\tau \dot{\nu} \nu$

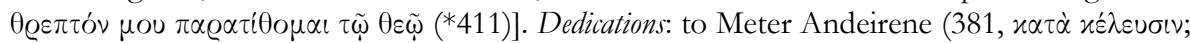
*404) [for the restoration of the first lines of no 404 see EBGR 2003, 142], Zeus (314, *376, $379)$ and Zeus Megistos $(343, * 377,396,418)$. [No 343 is not a 'dedication to Commodus', but a dedication to Zeus, in fulfilment of a vow, and i $\pi \dot{\varepsilon} \varrho \sigma \omega \tau \eta{ }^{\prime} \alpha \varsigma / \delta$ s $\alpha \mu$ ov $\tilde{\eta} s$ et sim. of Commodus Neos Helios, as one can easily infer from the fact that the emperor's name is in the genitive. In nos 376, 377, and $379 \mathrm{~J}$. reads $\varepsilon \dot{u} \chi \dot{\eta}$, where one expects $\varepsilon \dot{u} \chi \dot{\eta} \nu(c f .396,418)$. This is the case in 376, but 377 seems to have $\operatorname{s} x \eta^{\prime}[\nu]$ and 379 has a ligature of HN]. Neapolis: Dedications: Two brothers dedicated an altar to Sozon, in fulfilment of a vow (562:

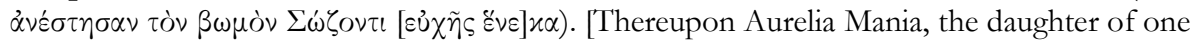

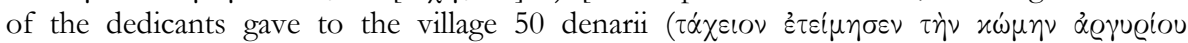
$\left.\delta(\eta v \propto \varrho i o \iota) \varsigma \nu^{\prime}\right)$, probably for sacrifices or a festival; the interesting feature of the text is the reference to the prompt and spontaneous ( $\tau \dot{\alpha} \chi \varepsilon ı v)$ donation]. The Dioskouroi (501) and (Meter) Dindymene (552) were the recipients of other dedications; no 505 mentions a temple

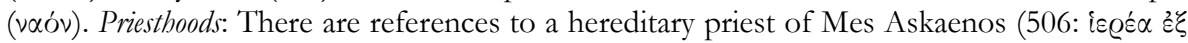

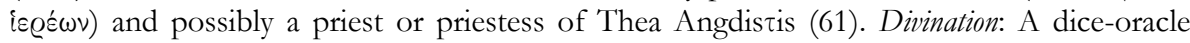

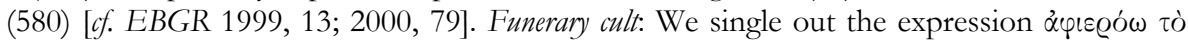

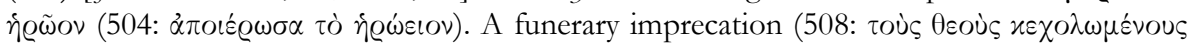

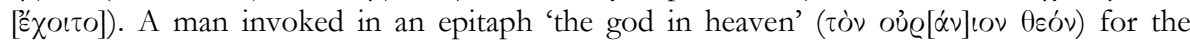
protection of his grave (509). [AC]

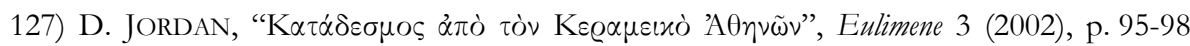
[BE 2003,139]: J. presents an improved edition of a defixio from the Kerameikos [supra $\left.n^{\circ} 54\right]$, observing that the third fragment does not join the other two. The text consists of two columns with the names of men in the nominative (i.e., the individuals being cursed) and the word $\gamma u v \alpha \tilde{i} x \alpha$, the significance of which is unclear. [AC]

128) D. JORDAN, "Une prière de vengeance sur une tablette de plomb à Délos", $R A$ (2002), p. 55-60 [BE 2003, 403; SEG LIII 813]: J. presents an improved edition of a lead tablet with a 'prayer for justice' found in a house in Delos, originally dated to the early 1 st cent. (Ph. Bruneau, Recherches sur les cultes de Délos, Paris, 1970, p. 650-655; cf. H.S. VerSnel, "Beyond Cursing: The Appeal to Justice in Judicial Prayers", in C.A. FARAONE - D. OBBINK (eds.), Magika biera. Ancient Greek Magic and Religion, Oxford, 1991, p. 67). The "prayer for vengeance' is addressed to the Dea Syria and the gods who live in the otherwise unknown place Sykon (a Syrian site?) by the owner of a stolen necklace; J. provides many parallels for similar prayers for justice against thieves. Because of the epithet xú@ıı, the letterforms, and the spelling, J. favors a date later than the destruction of the sanctuary of the Syrian gods (89 $\mathrm{BC}$ ), in the late 1st BC (or later). We present the entire text because of its great interest: A:

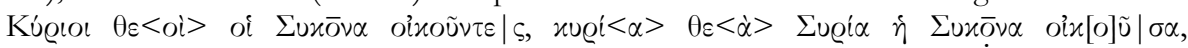




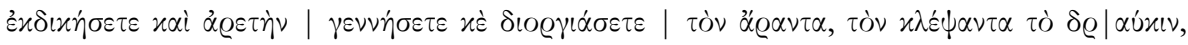

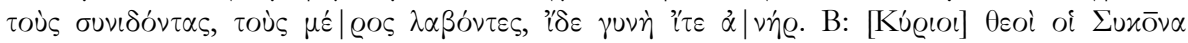

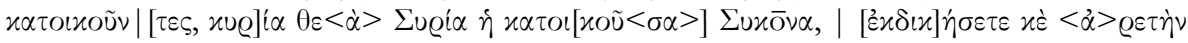

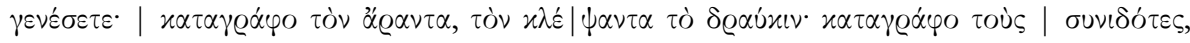

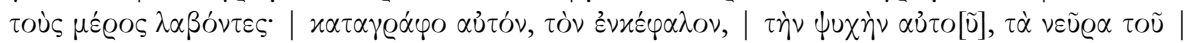

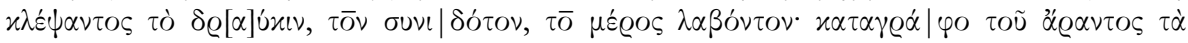

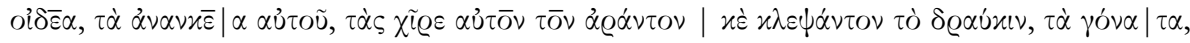

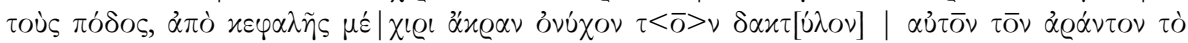

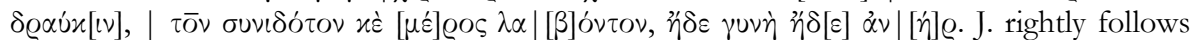

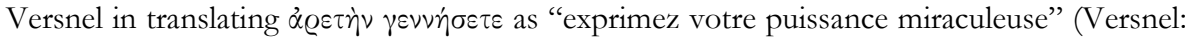

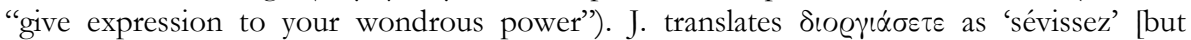

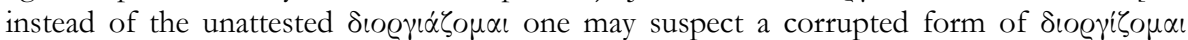
(pursue with great anger)]. J. also rightly recognizes in oi $\delta \bar{\varepsilon} \alpha$ a form of $\alpha i \delta \varepsilon i \alpha$ rather than Bruneau's ' $\delta \iota \alpha$, pointing out that $\tau \dot{\alpha} \alpha \nu \alpha \gamma \gamma \alpha \tilde{\imath} \alpha$ designates the genitals. [An alternative is to understand $\eta^{\prime} \delta \varepsilon \dot{\varepsilon} \alpha$. At any rate, the curse refers to the genitals ( $\alpha i \delta \varepsilon i \alpha=$ 'the shameful parts' or $\dot{\eta} \delta \varepsilon \alpha=$ 'the sweet parts') and the anus ( $\alpha v \alpha \gamma x \alpha i \alpha=$ 'the necessary parts, the organs for natural needs'); for this meaning of $\alpha \dot{\alpha} \alpha \gamma x \eta$ (still common in modern Greek) see LSJ. We translate: A: "God, lords, you who live in Sykon; Syrian goddess, mistress, you who live in Sykon; punish and show your miraculous power and show your anger (or show your frenzy?) against the person who took, who stole the bracelet, those who know about it, those who took part in it, wheter man or woman." B: "Gods, lords, those who live in Sykon; mistress, Syrian goddess, who lives in Sykon; punish and show your miraculous power. I am writing down the one who took, who stole the bracelet; I am writing down those who know about it, those who took part in it; I am writing down him, his brain, his soul, the nerves of the one who stole the bracelet, of those who know about it, those who took part in it. I am writing down the shameful parts (i.e., the genitals) of the one who took it, his necessary parts (i.e., the anus), the hands of those who took and stole the bracelet, the knees, the feet, (the body) from the head to the edge of the nails of the fingers of those who took the bracelet, who know about it, who took part in it, whether man or woman." I suspect that the author of the text was of Syrian origin, invoking the gods of his/her village (the gods of Sykon); thus a victim of injustice in a foreign place created a bond of solidarity with the local gods. The epithets xúgı and xugi $\alpha$ reproduce a relation of dependence and, again, morally oblige the gods to intervene, not in order to restore the stolen object, but in order to avenge the victim]. [AC]

129) D. JORDAN, 'Remedium amoris, a Curse from Cumae', Mnemosyne 56 (2003), p. 666-679 [BE 2004, 79; SEG LIII 1075]: J. presents with detailed commentary an improved edition of a love curse tablet from Kyme (Audollent, DefixTab 198; IG XIV 872; IGR I 415, 3rd cent. $\mathrm{AD})$. It consists of magical names (lines 2, 28-30), an adjuration of spirits in the name of a

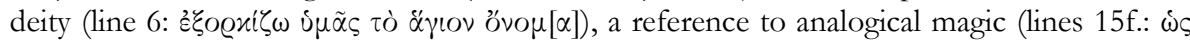

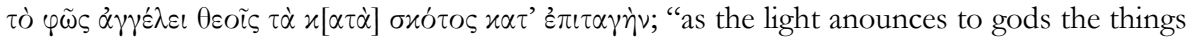
in darkness under order of ..."), and a series of commands aimed at making the husband,

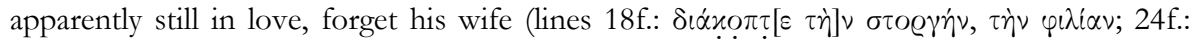

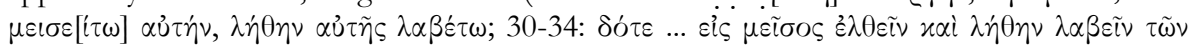
$\pi \dot{\theta} \theta \omega v$; "cut off the delight, the love for her; ... let him hate her, come to have forgetfulness of her; ... grant him to enter into hatred and to have forgetfulness of his desires") and make

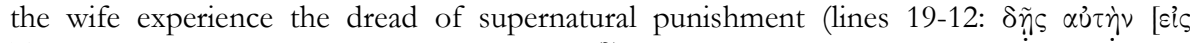

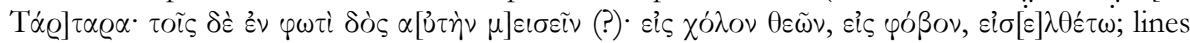

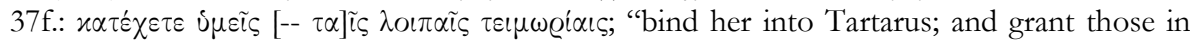
the light to hate her; let her enter into hatred of gods, into fear; ... control her with 
remaining punishments"). The text has an affinity with 'prayers for justice', since the author

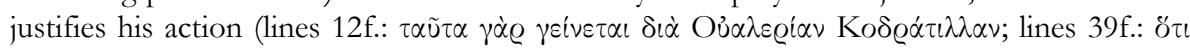

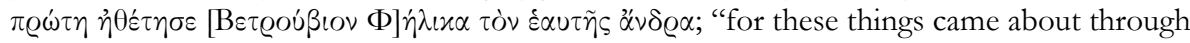
Valeria Quadratilla; ... because she first broke faith with Vitruvius Felix, her own husband";

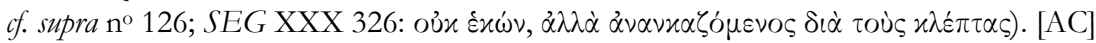

130) D.R. Jordan, "Magia nilotica sulle rive del Tevere", Mediterraneo antico 7.2 (2004), p. 693-710 [BE 2006, 66]: J. recognizes in a defixio allegedly from Rome (IG XIV 1047; Audollent, Defix.Tab. 188) and today kept in the British Museum a magical formula which is also known from a magical papyrus (PMG LVIII) and presents a new edition. The defigens commands in the name of Osiris an aoros to haunt a certain Nikomedes; he applies the magical strategy of diabole, accusing Nikomedes of having burnt the papyrus bed of Osiris and eaten sacred fish. The defixio once belonged to the collection of Francis Douce (early 19th cent.), and should consequently be regarded as of unknown provenance. With this text as his starting point, J. collects evidence for the circulation of instructions (magical spells and diagrammata) contained in magical handbooks. E.g., a diagramma known from PMG VII 217 finds close parallels in defixiones in the sanctuary of Poseidon at the Isthmus (EBGR 1993/94, 126) and at Hadrumetum; an unpublished defixio in Korinth which refers to the embalming of a corpse ( $\tau \dot{\alpha} \varrho\lfloor\chi \varsigma)$ must have copied an Egyptian recipe; a phylactery in Sicily (EBGR 1994/95, 199 no 32) presents itself as a phylactery used by Moses. [AC]

131) D. JORDAN, "Towards the Text of a Curse Tablet from the Athenian Kerameikos", in Attikai Epigraphai, p. 291-312 [BE 2005, 198]: J. presents a new reading of the first two columns of a defixio from the Athenian Kerameikos published by F. COSTABILE (EBGR 1998, 60; see supra nos 55). We record the most significant differences. Col. I, lines 6-9: xai

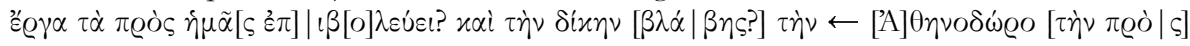

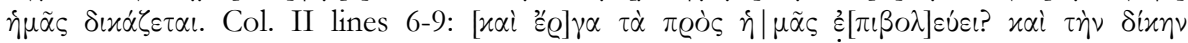

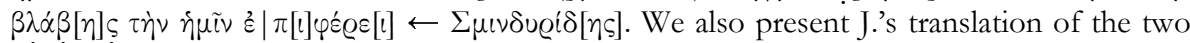
columns: I. "I bind down Athenodoros before Hermes Eriounios and before Persephone and before Lethe and his mind and tongue and soul and deeds that he is contriving against us and Athenodoros' suit for damages that he is pleading against us". II. "I bind down Smindyrides before Hermes Eriounios and before Persephone and before Lethe and his mind and tongue and his soul and deeds that he is contriving against us and the suit for damages that Smindyrides is bringing upon us". In an appendix, J. gives a list of other Attic curse tablets of the 4 th cent. that use forms of $x \alpha \tau \alpha \delta \varepsilon \varepsilon^{\prime} \omega$ other than the expected Attic $\varkappa \alpha \tau \alpha \delta \tilde{\omega}$; some of them have other non-Attic elements as well. In this context, J. briefly discusses another Attic defixio (DTWü 110), recently republished by K. Tsantsanoglou, who assumed that the scribe intentionally confused the sequence of the lines in observance of the similia similibus formula (see EBGR 1998, 270). J. suggests instead that the tablet or its writer's model was originally inscribed in two columns, and that either R. Wünsch or the ancient scribe copied the text as if all in one column. J. tentatively reads the text as follows:

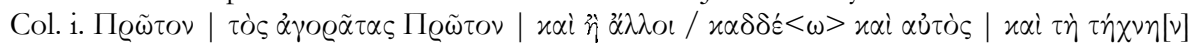

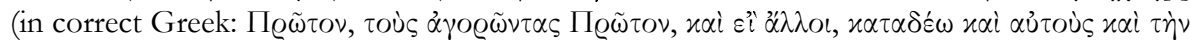
$\tau \dot{\varepsilon} \chi \vee \eta \nu$; "Protos, those speaking on behalf of Protos, and if [there are] others I bind them

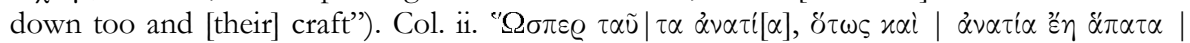

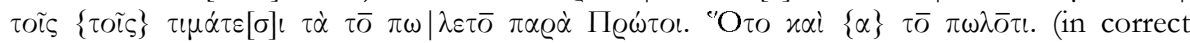

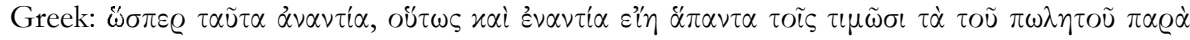

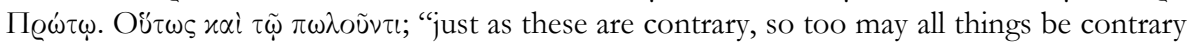
for those who fix the penalty for [or evaluate] the things of the seller that are in Protos' hands. So too for the seller)". [JM] 
132) D. JORDAN, "Rivers, Seas, and Rocks at PMG IV 360 and SupplMag 47.14", ZPE 147 (2004), p. 145-146: Three curse tablets (Suppl. Mag 47-49) ultimately derive from the same tradition as a magic spell in $P M G$ IV 296-406. A passage, best preserved in variations in Suppl. Mag. 46 and 48-49, describes the effect of uttering a powerful name: the earth opens, demons tremble, rivers and seas are afraid, rocks crack. In the light of these variants, J. proposes a new restoration of the relevant text in PMG IV 360 and Suppl. Mag. 47 line 14. [AC]

133) D. JORDAN, “Aлó $\varphi \lambda \varepsilon \gamma \mu \alpha$, addendum lexicis, at PMG LXI 8”, ZPE 147 (2004), p. 146: A spell in a magic papyrus (PMG LXI 8) mentions the sweat of Agathos Daimon, the mucus of Isis, and the phlegm ( $\dot{\alpha} \pi \dot{\varphi} \varphi \lambda \varepsilon \gamma \mu \alpha$, not $\dot{\alpha} \pi \dot{o} \varphi \theta \varepsilon \gamma \mu \alpha)$ of Helios. [AC]

134) M. Kajava, "Inscriptions at Auction", Arctos 37 (2003), p. 69-80: K. discusses one of the measures taken by the Lindians in order to increase the funds for the performance of public rituals: the offering at auction of statue bases on the acropolis and in the sanctuary of

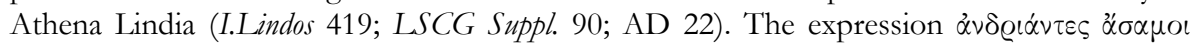
(lines 30-32) refers to statues (honorific statues, but perhaps also statues of gods) which were 'obscure' in the sense that it was no longer known whom they represented ( $c$. DIO CHRYS., Or. XXXI, 74). What was sold at auction was permission to inscribe the bases of such statues. The winning bid was subject to approval by the popular assembly. The term $\mu$ i $\sigma \theta \omega \sigma \varsigma$ ('lease') was perhaps used because the statue bases were immovable [as dedications to the gods]. [AC]

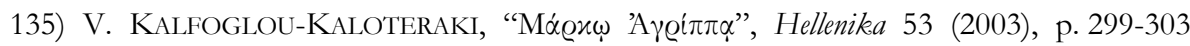
[SEG LIII 567 ter/quater]: Ed. pr. of two dedications to M. Vipsanius Agrippa who is worshipped with the epithets Theos Soter (Thessaly, c. 17-13). K.-K. collects the epigraphic

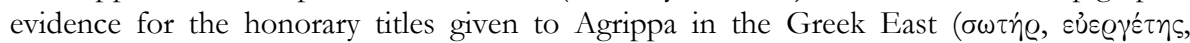

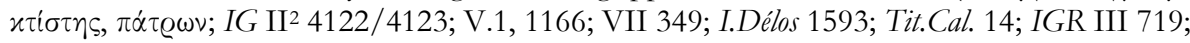
IGR IV 146; I.Ilion 86; A. BALLAND, Fouilles des Xanthos. Inscriptions d'époque impériale du Létôon, Paris, 1981, 45, no 23). Agrippa's cult is directly or indirectly atested in Samos, Kos, Sparta, and Smyrna (IG XII.6, 7; IG V.1, 374 = SEG XVIII 156; PH 104; I.Smyrna 331) [in SEG LIII 567 ter E. Sverkos adds an attestation in Lagina (SEG XLVII 1585/1586]. His cult as $\theta \varepsilon o ́ \varsigma$ in attested in Mytilene (IG XII.2, 66 c, 168, 170, 203). The titles $\theta \varepsilon o ̀ \varsigma ~ \sigma \omega \tau \eta \dot{\varrho}$, usually attributed to Augustus in Thessaly (IG IX.2. 93, 425, 604, 1288; SEG XXXIV 486; XXXV 612), reflect the close connection between Agrippa and Augustus; these dedications should be dated to the period of Agrippa's journey to the East. [AC]

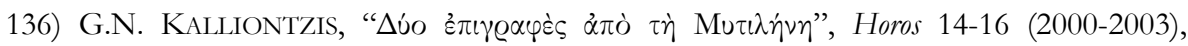
p. 255-258 [SEG LI 1029]: K. presents an improved edition of IG XII Suppl. 691 (Lesbos). The text is written on a funerary monument (2nd/1st cent.) reused as an altar in the 1 st

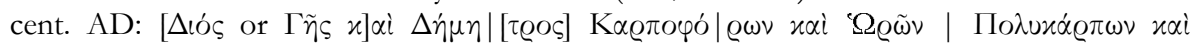

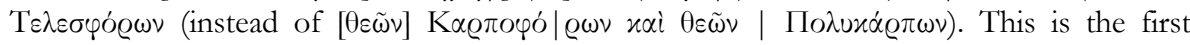
attestation of the cult of the Horai in Mytilene. K. provides parallels for the cult of Zeus Karpophoros and Ge Karpophoros and the joint cult of Demeter and Zeus or Ge. [JM]

137) E. Kapetanopoulos, "P. Herennius Dexippos (I) Hermeios", Horos 14-16 (2000-

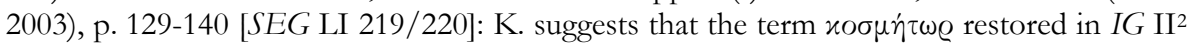
3671 line 5 and fully preserved in EM 4795 (3rd cent. AD) most probably refers to a

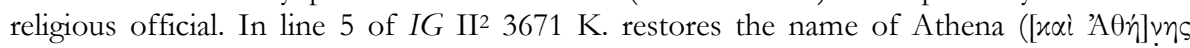
'IOvoixou). The epithet Ithydikos ['the righteous one'] is attested for Zeus in Olympia (I.Olympia 481, 3rd cent. AD). [JM] 
138) R.A. KeARSLEY, “Cultural Diversity in Roman Pisidia: The Cult of the Dioskouroi”, in Actes - Antioche de Pisidie, p. 401-416 [BE 2003, 535; SEG LII 1851-1856]: Ed. pr. of six dedications to the Dioskouroi dating to the early Imperial period (unknown provenance, probably Pisidia; now in the Burdur Museum). The texts are inscribed on altars and votive reliefs decorated with the image of a woman flanked by two riders. The dedications took place in fulfilment of vows (SEG II 1851-1855: sủx $\eta^{2}$ ) or in response to divine command

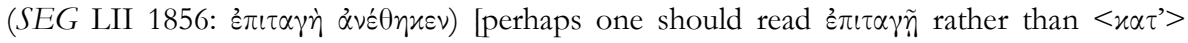
$\dot{\varepsilon} \pi \tau \alpha \gamma \dot{\eta}<\nu>$ (K.) or $\dot{\varepsilon} \pi \imath \alpha \alpha \dot{\eta}$ (SEG)]. The Dioskouroi are addressed with the epithets

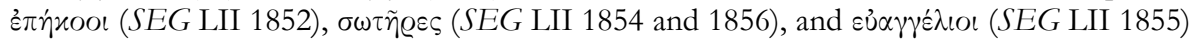

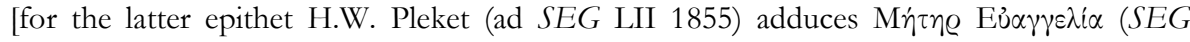
XXXIII 1072) as a parallel; cf. supra no 58]. K. attributes the identification of these Anatolian rider-gods with the Dioskouroi to the cultural influence that followed the integration of these areas in the Roman Empire. [AC]

139) P. KIYASHKInA, "One Uninvestigated Archaeological Site on the Territory of Burgas", in I. KARAYOTOV (ed.), Studia in memoriam Ivani Gălăbov, Burgas, 2000, p. 106-116 (in Bulgarian; English summary) [SEG LIII 643]: K. attributes a sanctuary on the Shiloto peak (near Bourgas, terrirory of Anchialos, Thrace) which has never been properly excavated to the cult of Apollon Karsenos ( $c$. IGBulg I ${ }^{2} 378$ ). K. briefly presents an inscribed dedicatory relief with a representation of the Thracian Rider (p. 110), dedicated to Apollo Karsenos

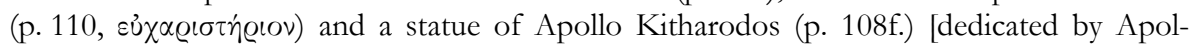
lonios, strategos of this province of the kingdom of Rhoimetalkes II who is also the dedicant of another dedication to Apollo Karsenos (IGBulg II 743); see M. OpPERMANN, Der Thrakische Reiter des Ostbalkanraumes im Spannungsfeld von Graecitas, Romanitas und lokalen Traditionen, Langenweißbach, 2006, p. 242, and the comments of A. AVRAM in SEG LIII 643].

140) G. KOKKOROU-Alewras, "New epigraphical evidence on the cults of Ancient Halasarna in Cos", in The Hellenistic Polis of Kos, p. 119-127: Ed. pr. of two Hellenistic decrees found in the sanctuary of Apollon in Halasarna on Kos. The first document (c. 250 BC) regulates the pledging of sacred vessels [certainly of precious material, though this is not explicitly mentioned in the decree]. The decree was proposed by two napoiai, Symmachos and Aristophanes. The decree forbade the priest and the timachoi to borrow money with the sacred vessels of the sanctuary of Apollon as surety. It also forbade anyone to receive these

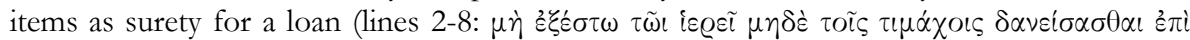

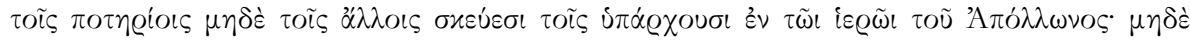

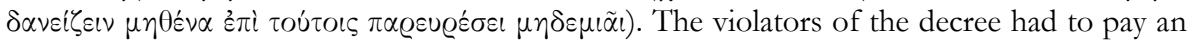
exorbitant fine to the sanctuary, amounting to 5.000 drachmas each (lines 10-12: $\dot{\alpha} \pi 0 \tau \varepsilon l \sigma \dot{\alpha} \tau \omega$

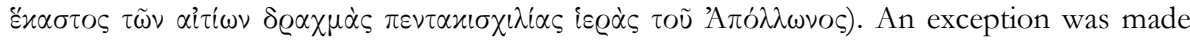
for those members of the demos of Halasarna who had the right to participate in the

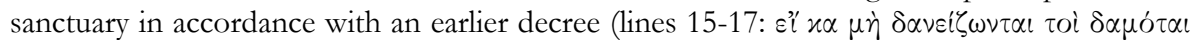

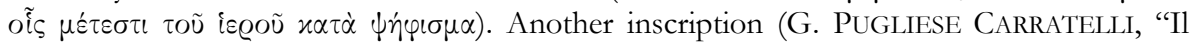
damos Coo di Isthmos", ASAA 25/26 [1963/64], p. 183-201 no xxvi) lists the demotai granted the right to participate in the sanctuary of Apollon because of their membership of the tribes Dymanes and Hylleis. K. suggests that the two napoiai mentioned in the new inscription belonged to these two tribes. The second document (c. 225-200) is a sacrificial calendar related to the annual sacrifices to be performed by the priest of Apollon (lines 5-7:

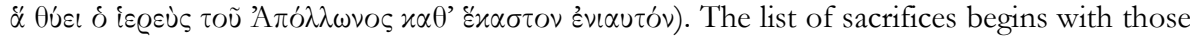
to be performed on the 12th of Hyakinthios. A male sheep was sacrificed to Hestia Phamia; it was permitted for the meat to be brought to the timacheion (lines 8-10: Mnvò ' Yaxivtiou

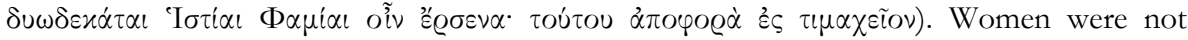

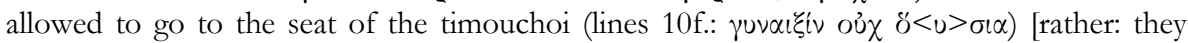


were not allowed to attend the sacrifice]. Apollon and Hestia Timacheia were to receive one

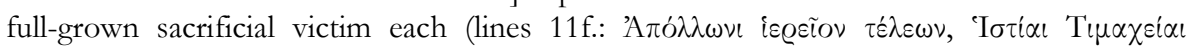

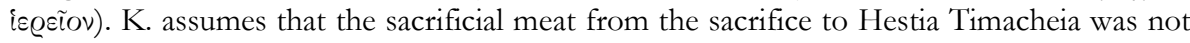
allowed to be brought to the timacheion because she was a chthonic deity. [But the oux

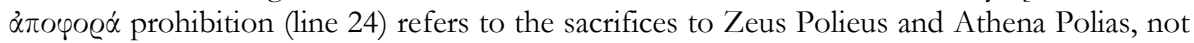
to all aforementioned sacrifices; and of course, Zeus Polieus and Athena Polias are not chthonic deities]. On the 19th of Hyakinthios a male and a female victim were to be offered

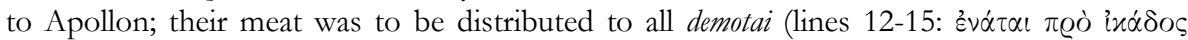

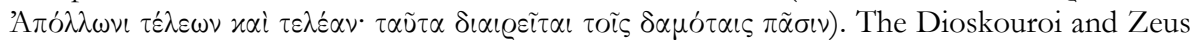

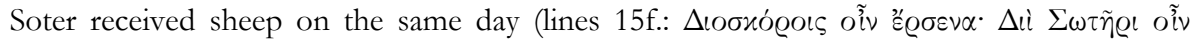
E $\varrho \sigma \varepsilon v \alpha$ ). On the 9th of Karneios a goat was to be sacrificed to Aphrodite (lines 17f.:

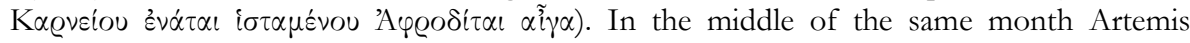
Agrotera received a sacrificial victim and Hekate Stratia a goat (lines 18-20: Sıxounvia

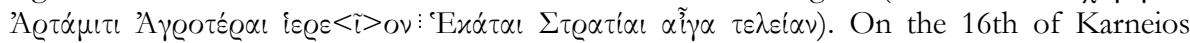
Zeus Polieus received a full-grown sheep on the acropolis and Athena Polias a ewe; every other year, the sacrificial meat was to be consumed at the site of the sacrifice (lines 20-24:

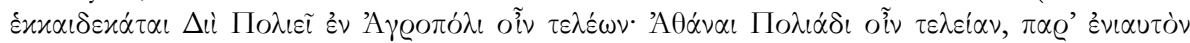

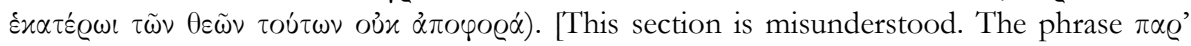

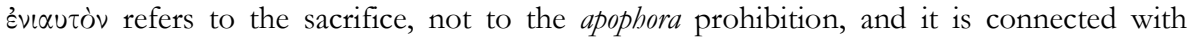
$\varepsilon \varkappa \alpha \tau \varepsilon$ $\varrho \omega \iota \tau \tilde{\omega} \nu \theta \varepsilon \tilde{\omega} \nu$ ("to each of these two gods alternately"); one should punctuate before

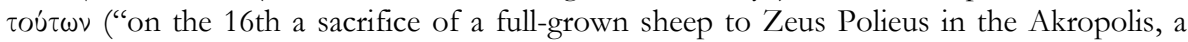
full-grown ewe to Athena Polias, alternately every other year to each of these gods; the meat of these sacrificial animals cannot be carried away/is to be consumed at the site"). A sacrifice was offered every year to both Zeus and Athena; the alternating sacrifice (one year to Zeus, the other to Athena) refers only to the obligation of Apollon's priest]. On the 20th

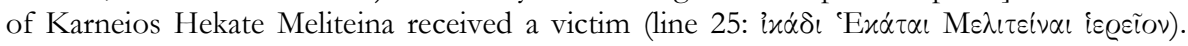
On the 16th of Theudaisios Apollon received a full-grown male and a female victim, Leto a

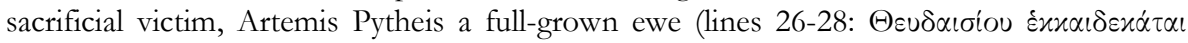

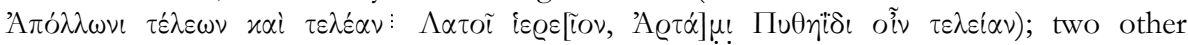
recipients seem to be Zeus Soter and Athena Soteira (lines 28f.: $\Delta_{\iota}\left[i \quad \sum \omega \tau \tilde{\eta} \varrho \iota\right.$, 'A $\left.\theta \dot{\alpha}\right] v \alpha \iota$ $\left.\sum \omega \tau \varepsilon^{\prime} \varrho \alpha \iota\right)$. [The inscriptions are also included in infra no 141 (5 and 6)]. [AC]

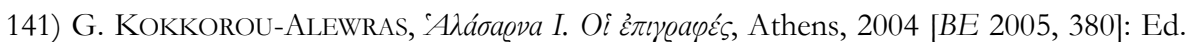
pr. of 21 inscriptions found since 1982 in the sanctuary of Apollon in Halasarna; for $n^{\text {os }}$ 5-6 see supra no 140 . In addition to the commentaries of the texts, K.-A. discusses the cults of Halasarna (p. 87-95) and presents a list of 69 inscriptions from Halasarna. Cults, festivals and rituals: The most important sanctuary was that of Apollon, where public documents were usually published $(1,5)$. The napoiai used the money of the sanctuary's treasury for the setting up of an inscription (1). A dedication was made to Apollon by the demos of

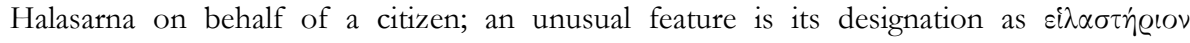
'A $\pi \dot{\partial} \lambda \lambda \omega v \iota$ (cf., e.g., PH 81, Imperial period). In the Hellenistic period, the priest of Apollon and the board of the hieropoioi regularly made dedications to Hekate Stratia $(8-11 ;$ if. infra W46; in $\mathrm{n}^{\circ} 8$ the priest has just finished his term). It seems that the dedication was made in commemoration of a sacrifice (11: $x \alpha \lambda \lambda \varepsilon \varepsilon \emptyset \dot{\eta} \sigma[\alpha \nu \tau \varepsilon]$ ]) [for annual dedications of magistrates in commemoration of the performance of a sacrifice see A. CHANIOTIS, "Die Inschriften von Amnisos", in J. SCHÄFER (ed.), Amnisos, Bonn, 1992, p. 294-296]. A fragmentary text

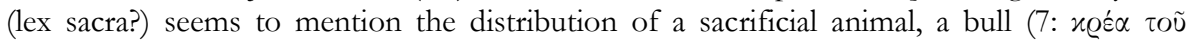
ßoó[s]). Honours were announced in Kos during the Dionysia (1-2) and the great Asklepieia (2), and in Halasarna during the Pythaia (4). Under the heading "those (whose honours)

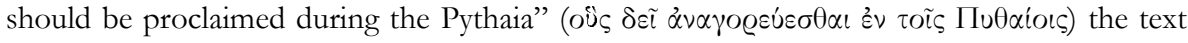


no 4 (c. 200-150 BC) lists persons who were to receive golden crowns by the board of

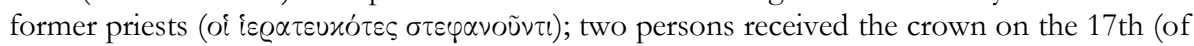
Dalios), another seven on the next day. [This text is important because it shows that the former priests constituted a board (as in Lindos), i.e., retained a certain corporate identity (see EBGR 2003, 40). The character of the list is also of interest. As we may infer from the epigraphic evidence, the announcement of honours could be postponed for years (e.g., SEG XXXVIII 143), and only selected benefactors received the honour of an early announce-

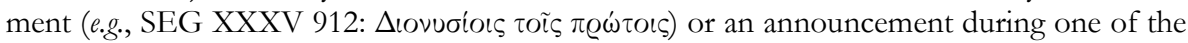
events for which one expected a large audience (e.g., I.Priene 108: "in the theatre, at the first (next) Dionysia, during the competition of the boys, when the demos performs the customary libations"); see A. CHANIOTIS, "Theatre Rituals", in P. WILSON (ed.), The Greek Theatre and Festivals. Documentary Studies, Oxford, 2007 (forthcoming); it seems then that this list aimed at securing for these important benefactors an announcement during the most important festival]. Religious offices: The texts attest the following offices: the napoiai of the

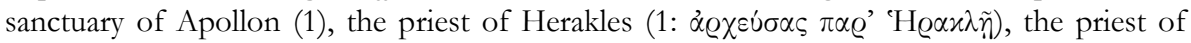
Apollon (8), and the boards of six hieropoioi (8-11) and (heridatary?) gerephoroi (15, 3rd cent. AD). No 7 alludes to the selection of a priest (of Apollon?) by lot (line 5: $\lambda \alpha \chi \dot{\omega} v$ iع@e[--]). Honorary inscriptions praise persons for the generous fulfilment of religious duties

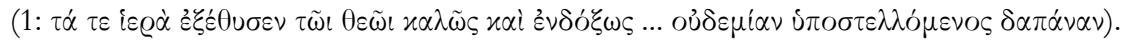

In an appendix ("Die Inschriften aus der Grabung Rudolf Herzogs in Halasarna (1902)", p. 125-138), L. Hallof and K. Hallof publish 20 inscriptions found by R. Herzog and contained in his notebooks. Formers priests made dedications to Apollon (W64 and W67, 2nd cent.). Another dedication is addressed to Hermes (W66, 3rd/2nd cent.). A boundary

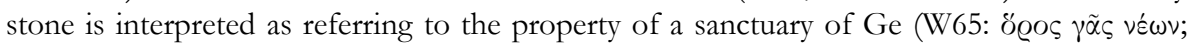
1 st cent.). [It is not clear why H.-H. exclude the possibility that an association of neoi owned

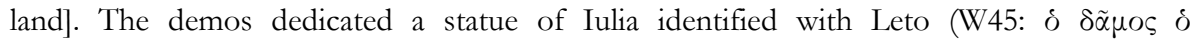

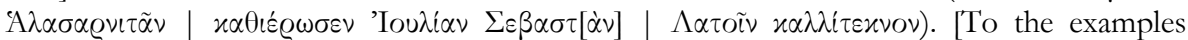
provided by H.-H. for texts that identify Iulia, the mother of Caius and Lucius Caesar, as a goddess of birth, one may add SEG XLVII 847 from Apollonia. As I have argued in SEG

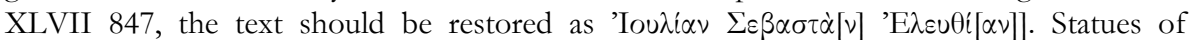
Vespasian and Titus were dedicated $(\varkappa \alpha \theta \varepsilon \varepsilon \omega \omega \sigma \varepsilon v)$ under the responsibility [with money administered by] the napoai $(\delta i \dot{\alpha} v \alpha \pi \circ \tilde{\alpha} v$, W47, W69). A dedication was made for the Fortuna of the emperors by the association of wine-pressers (W52: i $\pi \dot{\varepsilon} \varrho$ in $\varsigma \tau \tilde{\omega} v$

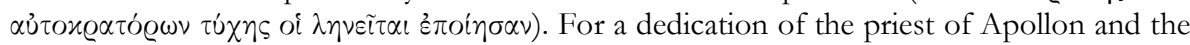
hieropoioi to Hekate Stratia (W46) see infra. [AC]

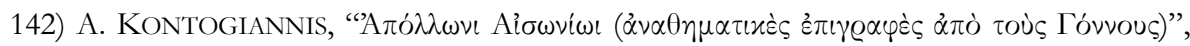
in Ergo - Thessalia, p. 125-143 [BE 2004, 222-223]: K. collects the epigraphic evidence for the cult of Apollon at Gonnoi. This evidence includes dedications to Apollon Agreus (Gonnoi 159), Apollon Aisonios (IG IX.2, 1098; SEG XXXV 570/571), Apollon Panlimnios (SEG XXIX 515), and Apollo (?; SEG XXXV 569). K. restores also in SEG XXIX 516-518 the epithet Aisonios and edits two new dedications to this god. One of the new dedications bears the remains of a painting (three or four oarsmen in a boat?). For this reason K. interprets Apollon Aisonios as a patron of seamen ( $c f$. the epithets Panlimnios, Aktios, and Embasios). K. attributes a dedication to Apollon Pythios (Gonnoi 158) to the neighboring city of Olympias (Gonnokondylos). Another dedication (Gonnoi 160) is of unknown provenance. $[\mathrm{AC}]$

143) K. Korhonen, Le iscrizioni del Museo Civico di Catania. Storia delle collezioni, cultura epigrafica, edizione, Helsinki, 2004: In her corpus of the inscriptions in the Museum in Catania,

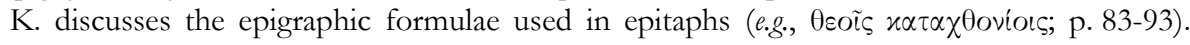


Most of the texts are in Latin (no new texts). The inscriptions from Katane include dedications to Demeter and Kore (1,5th cent.), and Apollon (8,3rd cent. AD: [Ф]oĩßov

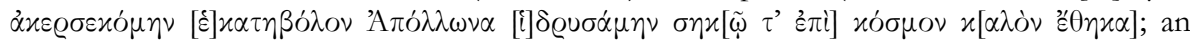
honorary epigram for an agonothetes (24, 3rd cent. AD); and a funerary epigram that gives the dates of birth and death of a child with reference to planets ( $\dot{\eta} \mu \varepsilon e_{\varrho} \alpha$ K@óvov, $\dot{\eta} \mu \varepsilon \dot{e} \alpha$ 'H $\lambda_{i o v}$; 174, 4th cent. AD) [cf. supra no 61]. The Museum of Catania has in its collection also a phylactery for the protection of a vineyard (Centuripe?, 235, 4th cent. AD or later) [cf. supra $\mathrm{n}^{\circ} 6$ and infra $\mathrm{n}^{\circ}$ 184] and a dedication to Theoi Pantes Soteres (Messene, 236, Imperial period). [AC]

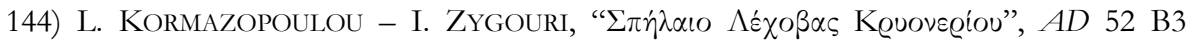
(1997) [2003], p. 1177-1178 [SEG LII 307]: The authors report the discovery of terracotta figurines (representing inter alia Pan), relief plaques, and other dedications found in a cult cave at Lechova, near Kryoneri (west of Sikyon, Archaic and Classical periods). Three vases have graffiti that designate them as dedications to the Nymph. [AC]

145) E. Kosmetatou, “Rhoxane’s Dedications to Athena Polias”, ZPE 146 (2004), p. 75 80 [BE 2005, 208]: Rhoxane, Alexander the Great's wife, appears among the dedicants of gifts to Athena Polias in Athens in one of the later inventories of the treasurers of Athena and the Other Gods ( $I G \mathrm{II}^{2}$ 1492, 305/4 BC). According to K.'s restoration, the text (A 4557) records three objects representing most probably a one-off dedication: a gold oinochoe

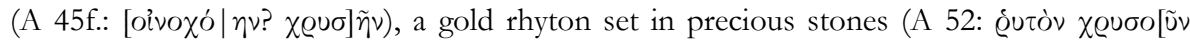

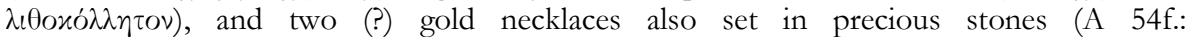

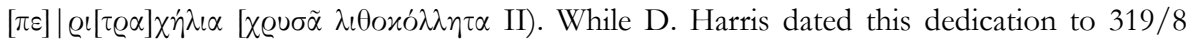
$\mathrm{BC}$, connecting it with a hypothetical visit of Rhoxane to Athens, $\mathrm{K}$. argues convincingly that the dedication could also have been made by proxy while Alexander was still alive. Thus, K. suggests a wider range of dates (c. 327-316 BC). [JM]

146) E. Kosmetatou, “Z $\omega \dot{\iota} \delta \iota \alpha$ in the Delian inventory lists”, Mnemosyne 57 (2004), p. 481 -

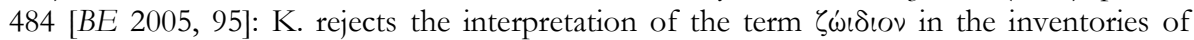
Delos as 'a figurine in the likeness of an animal' (suggested by C. PRÊTRE; see EBGR 1998, 213). The term $\zeta \omega$ เ $\delta$ เov primarily, but perhaps not exclusively, describes human statuettes. For example, the silver figurines of Apollon and Artemis dedicated by Kleino are described in the inventories as $\zeta \dot{\omega} \iota \delta\llcorner\alpha$ (IG XI.2, 161 B 11-12; 162 B 8-9; 199 B 42; I.Délos 333 Ba 5, 3rd

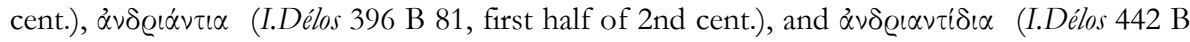
192-193; 443 B 117; 444 B 35-36; 461 Bb 25; 1444 Aa 13; 1449 c 15, first half of the 2nd cent.) [ $c$. supra no 26]. On the contrary, animal statuettes are referred to by the explicit name of the animal, in some cases in its diminutive form. [JM]

147) E. Kosmetatou, "Poseidippos, Epigr. 8 AB, and Early Ptolemaic Cameos", ZPE 142 (2003), p. 35-42: With an epigram of Poseidippos (epigr. 8 AB) describing a large cornelian cameo as her starting point, K. re-examines the question of whether large cameos were already produced in the early Hellenistic period. It is not clear if the royal portraits on priestly crowns mentioned in a letter of Antiochos III ( $R C 36$ lines 13f.) were cameo portraits or forehead-pieces $(\pi \varrho o \mu \varepsilon \tau \omega \pi i \delta i \alpha)$ adorned with metal medallions. The temple inventories of Athens and Delos mention intaglios ( $\sigma \varphi \varrho \alpha \gamma i \varsigma, \sigma \varphi \varrho \alpha \gamma i \delta \iota \nu v, \sigma \eta \mu \varepsilon i o v)$ with

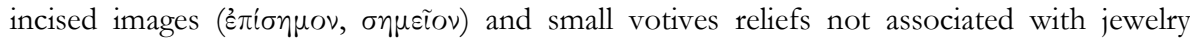

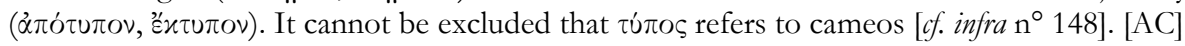

148) E. Kosmetatou, “On Large Gemstones”, ZPE 146 (2004), p. 81-84 [BE 2005, 93]: Gemstones listed in temple inventories are mostly associated with jewelry and sealstones. There are, nevertheless, some examples of pieces of onyx listed in the 4th cent. inventories 
of the Athenian Acropolis that seem to be an exception, since they appear too large to be used for jewelry (IG II I $^{2} 388$ B 62-63; 1400 line 57; 1401 d 45; 1407 line 30; 1415 line 20; 1421 IV 101; 1424 a III 294; 1425 A II 209; 1428 II 136; 1443 III 205; 1455 III 205; 1455 III 8; 1460 lines 23f.). K. suggests that the inventories refer to reliefs of some kind; in fact, in one case the formulation resembles the description of reliefs in the Delian inventories (IG

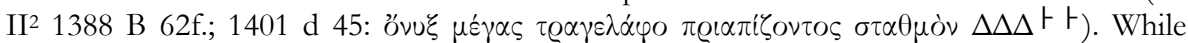
there is no secure archaeological evidence for the production of cameos before the late Hellenistic period [cf. supra no 147], K. cautiously suggests that these objects in the Athenian inventories may be early cameos. [JM]

149) E. Kosmetatou, “Persian' Objects in Classical and Early Hellenistic Inventory Lists”, MH 61 (2004), p. 139-170 [BE 2005, 94]: K. explores the possible criteria for defining the eastern provenance of offerings listed in the inventories from Athens (Acropolis and Asklepieion), Delos, Didyma, and Samos (5th-3rd cent.). She suggests that there must have been an inventory listing Kroisos' dedications in Delphi from which Herodotos drew his information. Persian objects are apparently already listed in the earliest inventories from the second half of the 5th cent. The axuv'axal (straight short swords) were most probably part of the war booty from the Persian Wars (e.g., IG $\mathrm{I}^{3} 343$ line 8). 33 silver-plated feet for dining couches (e.g., IG $\mathrm{I}^{3} 343$ lines 15s) and a silver-footed stool (IG II ${ }^{2} 1394$ lines 11-14) also seem to be of Persian or more generaly Oriental origin. The use of the more general adjective $\beta \alpha \varrho \beta \alpha \varrho$ เxó in the description of dedications may be an indication of their association with war spoils. Interestingly, foreign dedications not related to war booty are never described as barbarian in the relevant inventories. For example, several chitons dedicated to Hera of Samos are explicitly designated as Lydian and not as $\beta \alpha \varrho \beta \alpha \varrho$ ixoi (IG XII.6, 261 lines 12-17 and 27f.). Non war-related dedications can be identified as Persian either through their explicit characterisation as $\mu \eta \delta$ ixó (IG II 1424 a III 337) or through the name of the dedicator (IG II 1412 line 11). With regard to vessels made of precious metals, terms such

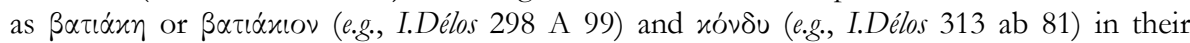
description may also indicate their Persian or Oriental origin. In a very useful appendix (p. 161-169) K. presents a catalogue of references to the dedication of Persian objects in the inventory lists of the aforementioned sanctuaries. [JM]

150) E. Kosmetatou - N. Papalexandrou, "Size Matters: Poseidippos and the Colossi",

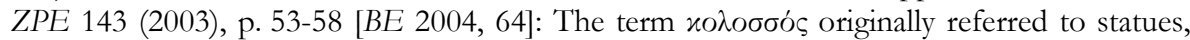
usually images of humans, the size of which could be determined from the context (e.g., IG

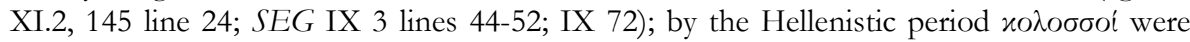
associated with large size ( $c f$. Poseidippos, epigr. 62 and $68 \mathrm{ed}$. Austin-Bastianini) [cf. M. Sève, BE 2004, 64 for some criticism]. [AC]

151) R. Kotansky - J. Curbera, "Unpublished Lead Tablets in the Getty Museum", Mediterraneo Antico 7.2 (2004), p. 681-691 [BE 2006, 516]: Ed. pr. of three lead tablets in the J. Paul Getty Museum. One of them (III), probably from Selinous, contains a defixio (early

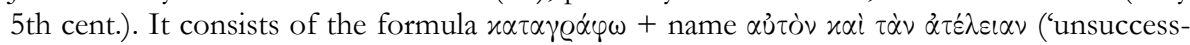
fulness'?) written 28 times against various victims. [AC]

152) T. KovaČEvA, Izvestija na Muzeite v Severozapadna Bulgarija 26 (1998), p. $63-64$ nº 8 [SEG LIII 729; non vidimus; cf. N. SHARANKOV, AE 2003, 1537]: Ed. pr. of a marble base and dedicatory relief; the relief represents Herakles and Diomedes (?); between Herakles' legs a bull and a boar (Oescus, 2nd/3rd cent.). The relief was dedicated by Aurelius Maximus to

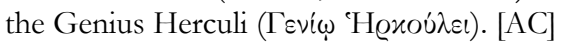


153) J. KRÄMER, 'Lateinisch-griechisches Glossar: Celtis' Abschrift aus einem Papyruskodex", in Paramone, p. 43-62: A manuscript in Vienna contains a Latin-Greek glossary copied by Konrad Celtis in 1495 in the monastery of Sponheim, probably from a papyrus codex of the 6th cent. AD. K. publishes the first five tituli, two of which (I. $\Theta \varepsilon \tilde{\omega} \nu$ óvó $\mu \alpha \tau \alpha$ xai $\pi \varrho o \sigma \eta \gamma o \varrho i \alpha l$; II. $\Theta \varepsilon \tilde{\omega} \nu$ óvó $\mu \alpha \tau \alpha)$ are of religious interest [cf. a list of epithets of Zeus in Miletos (SEG XLV 1612, 2nd cent. AD)]. We present a small selection of the Latin-Greek

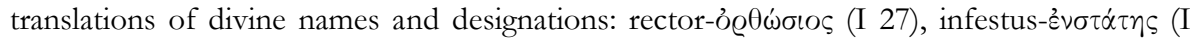

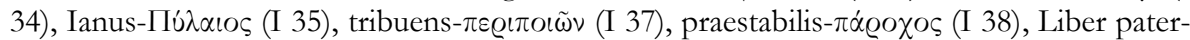

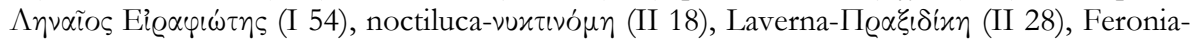

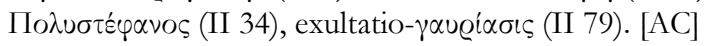

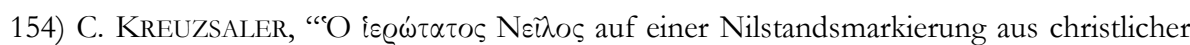
Zeit”, JJP 34 (2004), p. 81-86 [SEG LIII 1963]: K. presents an improved reading of an inscription on a late antique quay wall that records the inundation of the Nile (Elephantine, c. 550-600; J.H.F. DijKSTRA, "Late Antique Inscriptions from the First Cataract Area

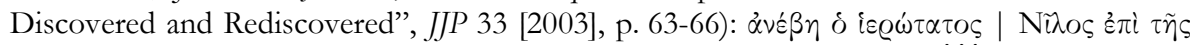

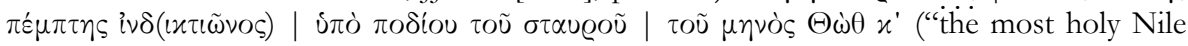
rose during the fifth indiction up to the foot of the cross; on the 20th of the month Thoth"). The most interesting feature of the text is the characterisation of the Nile as "most

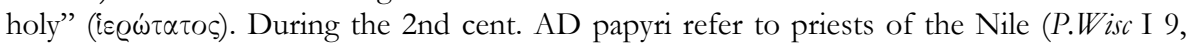
4s.) and to sacrifices in honour of the most holy Nile (P.Oxy IX 1211, 1-3). Until the discovery of this text, the latest reference to the most holy Nile was an inscription from Philae (I.Philai 187, late 3rd cent. AD). The new inscription is the only attestation of the

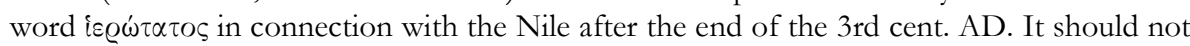
be interpreted as evidence for pagan cult activity; the scribe probably simply copied earlier texts. [JM]

155) C.B. KRITZAS, "Av $\alpha \theta \eta \mu \alpha \tau \varkappa \dot{~} \beta \dot{\alpha} \theta \varrho o$ $\lambda \alpha \mu \pi \dot{\alpha} \delta o \varsigma ”$, in Attikai Epigraphai, p. 271-289 [BE 2005, 79]: Ed. pr. of a marble base that supported a bronze votive torch (Athens, 1 st cent.):

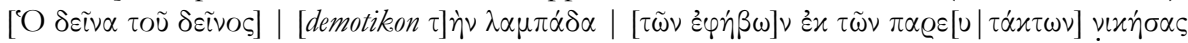

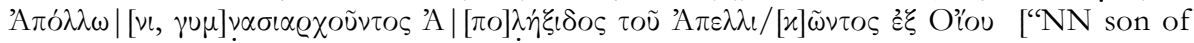
NN from the deme NN dedicated (the torch) to Apollon after his victory in the torch-race of the ephebes belonging to the age class of the pareutaktoi, during the gymnasiarchy of Apolexis, son of Apellikon from Oios"]. The festival during which the unknown pareutaktos won the torch-race is not named. The base was not found in situ (conjunction of Amalias and Vassilissis Sophias Avenues), and K. suspects that it could have stood either in the Lykeion, part of which has probably been located during excavations on Rigillis street, or in one of the sanctuaries of Apollon (Pythios, Delphinios) in the Ilissos area [see also EBGR 2000, $\left.153 \mathrm{n}^{\circ} 2\right]$. [JM]

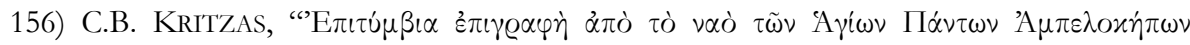

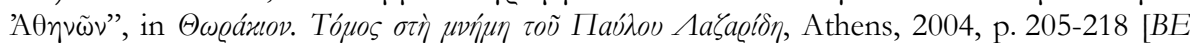
2004, 509]: Ed. pr. of three fragmentary funerary epigrams, all three written on the same stele, but probably for three different individuals (Athens, mid-4th and late 4th/early 5th cent. AD). Despite the very fragmentary state of preservation, $K$. shows that all three epigrams reflect the idea of the dualism of soul and body, possibly referring to the journey

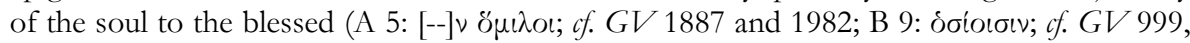

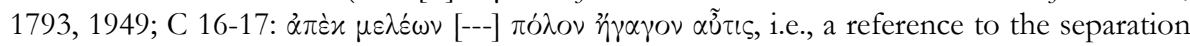
of the soul from the body and its journey to the stars; cf. GV 1760) [cf. supra no 61; SGO I

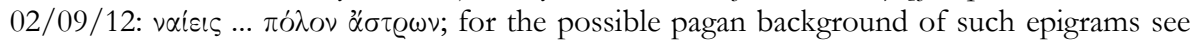
EBGR 2002, 21]. [AC] 
157) J. KubínskA, "L'ostothèque et le taphos dans une épitaphe d'Ancyre", Archeologia (Warsqawa) 46 (1995), p. 97-98 [SEG LIII 1445]: K. republishes an epitaph from Ankyra (CIG 4078; E. Bosch, Quellen zur Gescbichte der Stadt Ankara im Altertum, Ankara, 1967, p. 389f. $\mathrm{n}^{\circ}$ 324; Imperial period) discussing the terms used to describe the funerary

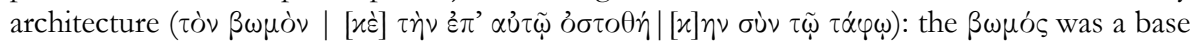

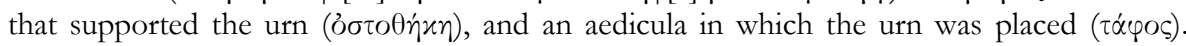
[AC]

158) J. KuBíNSKA, "Sépulture d'un Bithynien mort à Smyrne”, Archeologia (Warszawa) 45 (1994), p. 95-97 [SEG LIII 1335]: Reconstructing the history of a funerary monument in Smyrna (I.Smyrna 443; 2nd/3rd cent.), inscribed twice for two separate burials, K. gives a very instructive example of the appropriation of funerary monuments, but also at the same

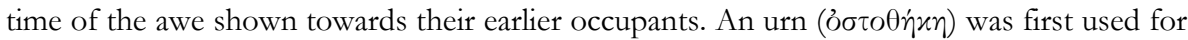
the burial of the Bithynian Quintus. Later, Metrodoros built a monument with niches for his family, appropriating the urn of Quintus, a foreigner, because of its decorative value and

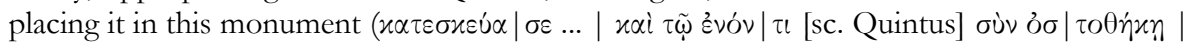

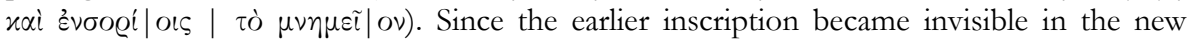
arrangement, Quintus is anonymously referred to in the text as 'the one inside'. [AC]

159) G. Labarre - M. Tahlialan, "La dévotion au dieu Men : les reliefs rupestres de la Voie Sacrée", in Actes - Antioche de Pisidie, p. 257-312 [BE 2003, 526; SEG LII 1378-1382]: 152 naiskos-stelae, cut on the rock along the sacred road that leads to the temple of Men on Mt. Gemen Dag (Antiocheia in Pisidia), have been found, usually decorated with the god's symbol (a crescent) and wreaths. A few stelae are inscribed with dedications to Mes Askaenos $(69+70+71,135)$ or Askaenos (72-74) in fulfilment of a vow $(69+70+71,135$ :

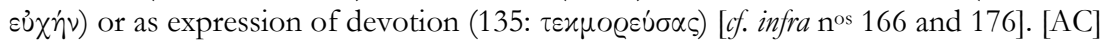

160) S.D. LAMBERT, “The First Athenian Agonothetai”, Horos 14-16 (2000-2003), p. 99-105: The epistyle of a substantial gateway near the entrance to the theatre of Dionysos records victories in tragedy and comedy and attests the earliest known Athenian agonothetes (IG II ${ }^{2}$ 3073, 307/6 BC). Based on the fully preserved demotic and the securely restorable patronymic, the agonothetes has always been identified as Xenokles, son of Xeinis of Sphettos. L. restores the name of Androkles, Xenokles' brother. Another agonistic inscription (IG II ${ }^{2}$ $3077,307 / 6$ BC) seems to record the agonothesia of Xenokles. According to L., the two distinguished brothers served as agonothetai either in close succession or more probably in the same year. [JM]

161) S.D. LAMBERT, “Two documents of Attic Gene”, Horos 14-16 (2000-2003), p. 77-82 [BE 2004, 142; SEG LI 73]: L. associates a fragmentary documentary relief found near the Eurysakeion (C.L. LaWTON, Attic Document Reliefs, Oxford, 1995, p. 134 no 120, 346/5 BC) with the genos of the Salaminioi, who supplied the priest for this shrine. L. convincingly dismisses the assumption of M. MEYER (Die griechischen Urkundenreliefs, Berlin, 1989, p. 120) that on the relief the personification of Salamis (identified by a label) was accompanied by Aias. Salamis was represented together with Athena, expressing the double identity of the genos. L. also studies an altar from the Athenian Agora, recently republished by M. Jameson

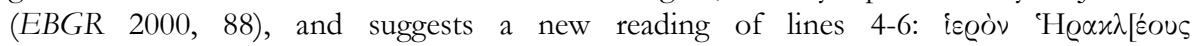
$\Pi \varrho \alpha]\left|\xi_{\iota \varepsilon \varrho \gamma \iota \delta \tilde{\omega} \nu} \varkappa \alpha[i \quad \theta \iota \alpha \sigma \omega \tau]\right| \tilde{\omega} \nu \tau \tilde{\omega} \nu \delta \varepsilon$ oís $\mu[\varepsilon \dot{\varepsilon} \tau \sigma \tau \imath]$ ("hieron of Herakles of the Praxiergidai and of the following thiasotai who share [in it]"). The shrine of Herakles belonged apparently to the genos of the Praxiergidai, while the thiasotai must have been guests or cousers [see also EBGR 1999, 139]. [JM] 
162) S.D. LAmberT, 'Athenian State Laws and Decrees 352/1-322/1', ZPE 150 (2004), p. 85-120 [BE 2005, 204]: L. collects and discusses Athenian honorary decrees for Athenian holders of public offices, such as councillors, holders of religious offices (priests, hieropoioi) and officials responsible for the Ampihareion. In many cases he presents improved editions. [AC]

163) S.D. LAMBERT, "Greek Inscriptions in the University Museum, Oxford, Mississippi", ZPE 148 (2004), p. 181-186: L. republishes five inscriptions (2-6), based on autopsy, and presents the ed. pr. of a sixth one (1), all in the University Museum at Oxford, Mississippi. The new text is the fragment of a stele (1, early 3rd cent. AD) apparently commemorating a victory (line 15: vei(x) ) in the Olympic games (line 10: "H been allowed to set up a statue (?) made of bronze (line 6: $\chi \dot{\alpha} \lambda \varkappa \varepsilon o v)$. The republished texts include two fragments of inventories from Athens (2, 4th cent.; $4=$ SEG XXXV 1731, Eleusis?, late 4th cent.?) and a fragment of an Athenian decree (3, SEG XXXVI 149, c. 330 BC) probably referring to the rebuilding of the theatre of Dionysos under Lykourgos. L. suggests that the proposer and/or secretary were the same as in the famous decree for Eudemos from Plataia (IG II $\left.{ }^{2} 351\right)$. [JM]

164) A. LARONDE, "Les rivalités entre les cités de la Cyrénaïque à l'époque impériale", in L'hellénisme d'époque romaine, p. 187-193: L. draws attention to a very interesting letter of Antoninus Pius addressed to Ptolemais-Barka (SEG XXXVIII 1566 lines 78-85, Kyrene, AD 153/4); the emperor criticises Ptolemais for having recently sent a delegation to the Capitolia in Rome for the first time, because such actions caused strife among poleis

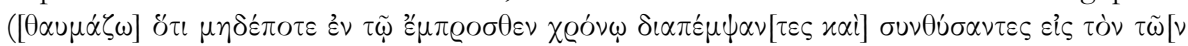

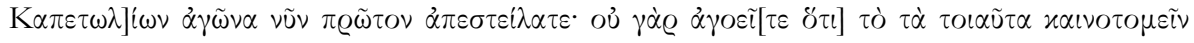

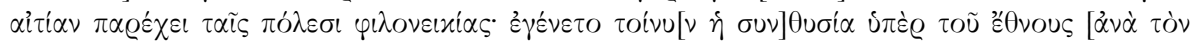
$\dot{\alpha}] \gamma \tilde{\omega} \nu \alpha)$ ["I am amazed that although you have never sent a delegation and participated in the joint sacrifice at the contest of the Capitolia in the past, you have now sent a delegation for the first time; for you very well know that such innovations cause strife among the cities. The joint sacrifice was offered during the contest on behalf of the ethnos (i.e., the cities of Kyrenaika)"]. Ptolemais' initiative is to be seen in the context of rivalries among the cities of Kyrenaika, rooted in the history of the region. [It is also an interesting example of how festivals could be an arena for political rivalries and the promotion of political claims]. [AC]

165) M.L. LAZZARINI et al., "Iscrizioni inedite di Ostia", Epigraphica 64 (2002), p. 184-189 [SEG LII 966-968]: Ed. pr. of three Greek epitaphs in Ostia (2nd-4th cent.). In addition to

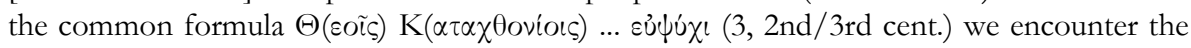
rare pagan formula $\Theta(\varepsilon \circ \tilde{\imath} \varsigma) \mathrm{M}(\nu \dot{\eta} \mu \alpha \sigma \iota)$ (2, 3rd/4th cent.; cf. IGUR 922) co-existing with the

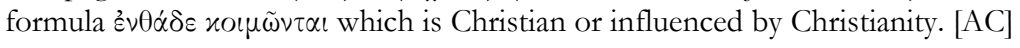

166) M.-T. LE DinAHET, "Les inscriptions votives au dieu Men à Antioche: état des recherches", in Actes - Antioche de Pisidie, p. 201-212 [BE 2003, 527; SEG LII 1370-1377]: L. presents improved editions of six dedications to Mes from Antiocheia in Pisidia (1-4, $6=$ SEG XXXI 1207, 1219, 1222, 1256+1257, 1259) and a new text $(* 5)$ [on the cult of Mes in Antiocheia see supra $\mathrm{n}^{\circ} 159$ and infra $\left.\mathrm{n}^{\circ} 176\right]$. The texts were made in fulfilment of a vow (3-

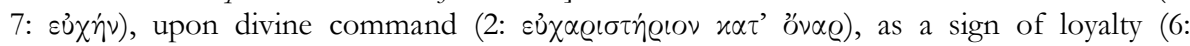
$\tau \varepsilon x \mu о \varrho \varepsilon u ́ \sigma \alpha \varsigma)$, or for the well-being of family members (3-4). The epithet Askaenos is used in two cases $(* 5,7)$. $[\mathrm{AC}]$

167) M.-T. LE DiNAHET, “Cultes étrangers et cultes locaux dans les Cyclades à l'époque impériale", in Les cultes locaux, p. 129-142 [BE 2004, 232]: Based almost exclusively on the epigraphic evidence, the author demonstrates that despite the economic decline of the 
Cyclades between the 1 st and the 4th cents. AD, religious life was still very vibrant. Inscriptions attest the cult of Eileithyia (IG XII.5, 194, 199, 1022, 1023), Asklepios and Hygieia (IG XII.5, 156-159, 161-165, 170-175, 180), and Sarapis (SEG XXVI 967, 968) on Paros; Asklepios (IG XII.3, 516, 865), Apollon Karneios (IG XII.3, 516), Dionysos (IG XII.3, 522), Hera Dromaia (IG XII.3, 513), and Eileithyia (IG XII.3, 326) on Thera; Eileithyia (IG XII.5, 944) on Tenos; Athena (IG XII.3, 1077, 1079), Asklepios and Hygieia (IG XII.3, 1085-1087) on Melos; Isis (IG XII.5, 738) on Andros; and Sarapis and Isis on Amorgos (IG XII.7, 429). [JM]

168) C. Lehmler - M. WÖrRle, "Neue Inschriftenfunde aus Aizanoi III. Aizanitica Minora", Chiron 32 (2002), p. 571-646 [SEG LII 1250-1278]: Ed. pr. of funerary altars from the territory of Aizanoi. No 5 was erected by a hieros for his mother ( $2 \mathrm{nd} / 3 \mathrm{rd}$ cent.). [AC]

169) C. LE Roy, "Dieux anatoliens et dieux grecs en Lycie", in Les cultes locaux, p. 263-274: Based on the archaeological and epigraphic evidence (mainly the bilingual inscriptions from Lykia), the author argues that Artemis was introduced to Lykia without taking the place of. or being assimilated with, an older goddess. He suggests that the importance given to Artemis in the Letoon of Xanthos played a significant role in the introduction of her cult to Lykia. [JM]

170) B. LEVICK, “'How different from us': Inscriptions of Pamphylian Cities under the Roman Empire", in L'hellénisme d'époque romaine, p. 255-275: Based on epigraphic, archaeological, and numismatic sources, L. surveys the many different processes of interchange between the Graeco-Anatolian and new Roman elements in Pamphylia. Older Greek divinities like Apollon and Athena in Side or Zeus and Hera in Aspendos witnessed the emergence of new ones, such as the cult of Thea Archegetis Roma in Attaleia (SEG II 696), evidently modelled on Apollon Archegetes of Side, or of unique cults in a Pamphylian context like the cult of the river Tiber (also in Attaleia: SEG XVII 594). The new cults were closely connected with the Italian immigrants, but the immigrants also played an important role in the traditional religious life of the Pamphylian cities. Italians served as gymnasiarchoi and agonothetai (SEG XVII 575, 578, 584) or held important priesthoods such as the priesthood of Artemis Pergaia (SEG XXXVIII 1397). [JM]

171) T. Lochman, Studien zu kaiserzeitlichen Grab-und Votivreliefs aus Phrygien, Basel, 2003 [SEG LIII 1448, 1451-1452, 1460-1462, 1472-1474, 1490-1501, 1520-1523, 1536, 1541, 1545, 1548, 1565]: This general study of funerary and dedicatory reliefs in Phrygia includes a study of the iconography of Zeus Bennios, Zeus Bronton, Zeus Soter, Zeus Thallos, Zeus Ampeleites, Zeus Andreas, Zeus Asklepiades (founded by Andreas and Asklepiades respectively), Hekate, and Hosios kai Dikaios (p. 81-93), a catalogue of 146 inscriptions concerning the cult of Hosios kai Dikaios (p. 199-207, including a few unpublished texts) and an appendix with a catalogue of funerary and votive reliefs which includes many inscriptions (also inedita, p. 239-319). Aizanoi and its area: Two altars dedicated to Hosios kai Dikaios (p. 200f. nos 93 and 98; $\mathrm{n}^{\circ} 93$ is decorated with a female bust with polos and a male bust with radiate crown, $138 \mathrm{AD}$; $\mathrm{n}^{\circ} 98$ is decorated with a bust of Mes and a bust of Hosios kai Dikaios on the front, and Apollon with double axe on horseback on the left side; the names of Hosios, Dikaios, and Apollon are written above the respective figures; the relief was dedicated by a village $\varepsilon \dot{x} \tilde{\eta} \varsigma \chi \chi \alpha \varrho(v)$. Tembris Valley: Dedications: The most important group consists of the dedications from the sanctuary of Hosios kai Dikaios at Yaylababa (p. 286-289; cf. EBGR 1991, 202; SEG XLI 1205-1235). L. gives new readings and restorations in a few cases; the most significant new restoration is in SEG XLI

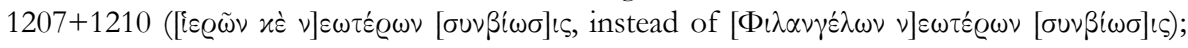

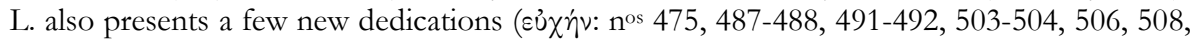




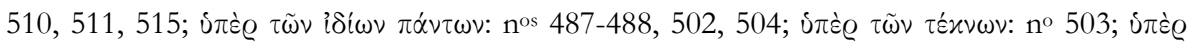

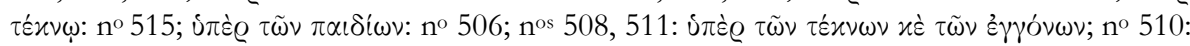

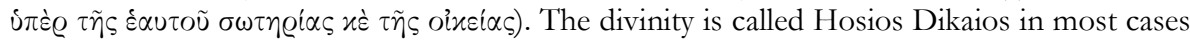
(n ${ }^{\circ s}$ II 475, 502-504, 506, 508, 510, 511, and 515), but also the form Hosios kai Dikaios is attested ( $\mathrm{n}^{\text {os }}$ II 487-488, 491-492); the addressee is not stated or preserved in two dedications ( $n^{\text {os }}$ II 486 and 507). Other dedications are addressed to Zeus Anpeleites as a

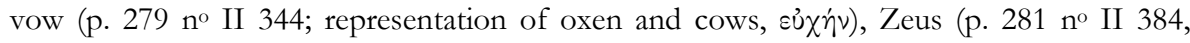
sủxฑ́v), and Zeus Thallos (p. 281 n II 387, not Zeus Anpelos as read in EBGR 1991, 203); a stele with the representation of Zeus and two oxen, dedicated to Hekate in fulfilment of a vow (p. $285 \mathrm{n}^{\circ}$ II 465); an altar with the representation of Hosios kai Dikaios on horseback and Helios with radiate crown dedicated to Hosios kai Dikaios in fulfilment of a vow (285 $\mathrm{n}^{\circ}$ II 469); an altar with a representation of Herakles and oxen dedicated to Zeus Herakles by a man $\dot{\delta} \pi \grave{\varepsilon} \varrho \tau \tilde{\omega} \nu$ i $\pi \alpha \varrho \chi o ́ v \tau \omega \nu$ (p. 290 no II 527, AD 250). Funerary cult: Two funerary imprecations with the 'North Phrygian curse formula' (260-263 nos II 95 and 118, 2nd cent.

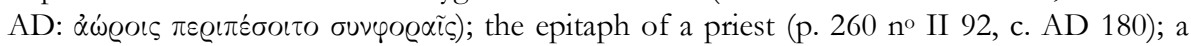

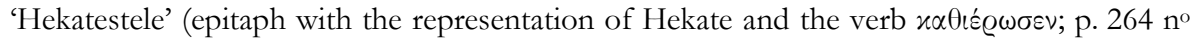

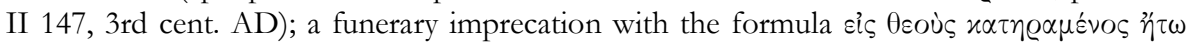
(p. 274 no II 253, late 2nd cent. AD); two funerary imprecations with the formula tòv $\Theta \varepsilon o ́ v$ $\sigma o l, \mu \dot{\eta} \dot{\alpha} \delta \iota \dot{\eta} \sigma \varepsilon \iota \varsigma$ (p. 275 nos II 266 and 270, 3rd cent. AD). Dokimeion and Kaystros Valley: A dedicatory relief with a representation of Apollon was dedicated to Zeus Alsenos (p. $302 \mathrm{n}^{\circ}$

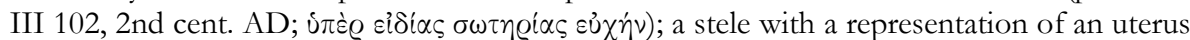
(?) was dedicated to Zeus Petarenos in fullfillment of a vow (p. $306 \mathrm{n}^{\circ}$ III 219). An epitaph with a representation of raised hands gives the text of a funerary imprecation (p. 298 no III

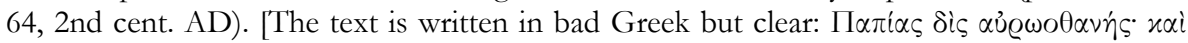

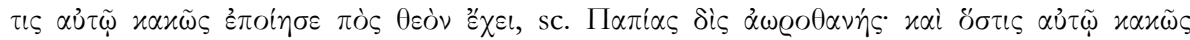

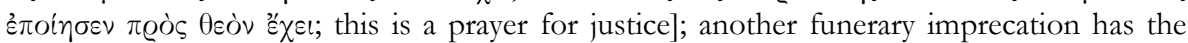

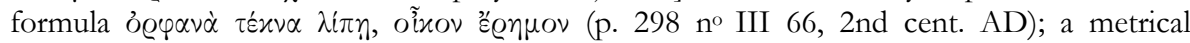

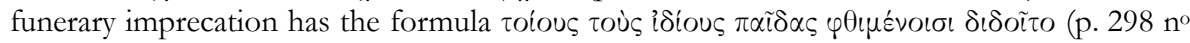
III 67, 2nd cent. AD). [AC]

171bis) F. LOZANO, “Thea Livia in Athens: Redating IG II2 3242”, ZPE 148 (2004), p. $177-$ 180: The dedicatory inscription to Livia from Rhamnous ( $I G \mathrm{II}^{2} 3242$ ) recording the consecration of the temple of Nemesis to Livia refers to her as Thea Livia. This characterization has always been used as an argument pointing to a date of consecration of the temple after AD 41 (the date of Livia's deification at Rome). The inscription has been traditionally dated to the Claudian era, despite the fact that Livia was already worshipped in Athens under Augustus and Tiberius. In addition to this, Livia received the title Thea Sebaste in Athens (and in other cities of the Mediterranean) from the reign of Claudius onwards. L. suggests an Augustan date for the inscription, a date which can be perfectly supported by the inscription itself: The inscription refers to a certain Demostratos, son of Dionysios from Pallene, as general of the hoplites and priest of Rome and Augustus Caesar. The same person acted as a sacred official at Eleusis around 20/19 BC (SEG XXX 93). According to this new interpretation the consecration of the temple of Nemesis to Livia took place in the reign of Augustus itself. [JM]

172) S. LÜCKE, "Ein Bronzetäfelchen aus dem syrisch-ostanatolischen Grenzgebiet", Klio 86 (2004), p. 55-65: Ed. pr. of a small bronze tablet (c. $13,2 \times 7,8 \mathrm{~cm}$ ) of unknown provenance in a private collection. L. suggests that the object comes from North Syria or Eastern Anatolia and dates it to the late 2 nd or 1 st cent. From the existence of two holes one may infer that the extremely thin tablet $($ c. $1 \mathrm{~mm}$ ) was originally attached to another object. The text certainly refers to sacrifices (line 3: $\theta v \sigma \alpha \dot{\tau} \omega$ ) to Zeus (line 3), to Hera (line 9), and to an 
unknown king Demetrios (line 10). The number of sacrificial animals and other offerings is remarkable: 100 unknown white animals, another 100 unknown animals, and 100 rams are to be sacrificed to Zeus, offered together with 100 metretai of wine and 100 medimnoi of flour

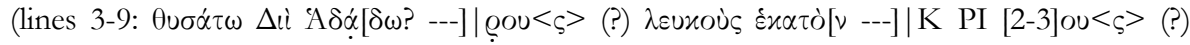

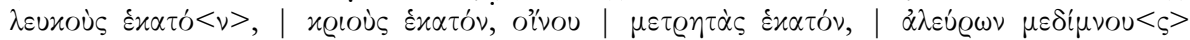

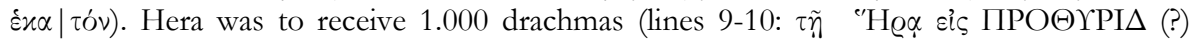

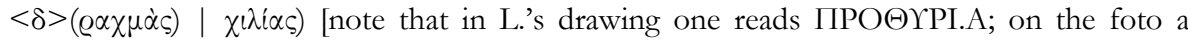
letter seems to exist before A]. The same amount was to be offered to king Demetrios (lines

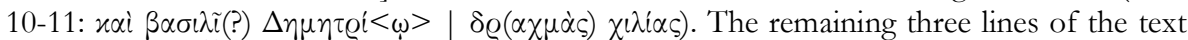

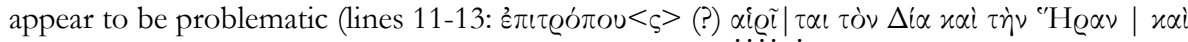
$\left.\beta \alpha \sigma \iota \hat{\varepsilon}^{\prime} \alpha \Delta \eta \mu \eta^{\prime} \varrho \iota<o \nu>\right)$. L. suggests that Zeus, Hera, and king Demetrios were to be the guarantors of the aforementioned sacrifices and offerings. According to the author, the text cannot describe everyday sacrifices in a sanctuary, but presents the possible penalty for a crime defined in the missing part of the text. [JM]

173) P. Lungarova, in Studia protobulgarica et mediaevalia Europensia. A Festschrift in Honour of Prof. Veselin Beshevliev, Sofia, 2003, p. 135-139 [non vidimus. See AE 2003, 1563; SEG LIII 726]: Ed. pr. of an inscription that records the dedication of a column by a priest of the

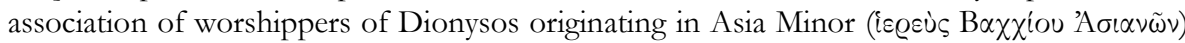

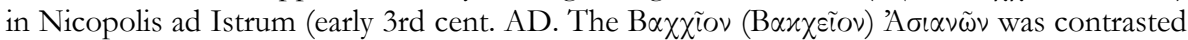
to the association of the local population (ILBulg 438: bacchium vernaculorum). [AC].

174) J. MA - S.V. Tracy, "Notes on Attic Statue Bases”, ZPE 150 (2004), p. 121-126 [BE 2005, 78]: In the Hellenistic world (with the exception of Athens), the erection of honorific statues is usually expressed with a dedicatory formula consisting of $\delta \delta \tilde{\eta} \mu \circ \varsigma$ followed by the name of the honorand in the accusative, the reason for the honour, the verb $\alpha v \varepsilon \dot{\varepsilon} \theta \eta \varepsilon v$ and the name of the deity; this formula obviously originates in votive practices. By contrast, in Athens the name of the honorand on the statue base seems to have been perfectly sufficient. M.-T. review three Athenian inscription showing that the more elaborate formula cannot have been used there. In the case of $I G \mathrm{II}^{2} 3454$ they show that it was not a statue base but an honorary stele for the priest Aristokrates, son of Physkion, from Phaleron. They date the inscription to the first half of the 2 nd cent., thus excluding an identification of the priest with a 4th cent. Aristokrates from Phaleron (IG II'2 2318). [JM]

175) A.K. MAKRES, “The Rediscovery of IG I3 253-254”, in Attikai Epigraphai, p. 123-140: The back side of an opisthographic inscription from Ikarion, already discovered in 1888 and thought lost for more than a century, was rediscovered in 1999 in the storerooms of the Epigraphical Museum in Athens ( $I G \mathrm{I}^{3}$ 254). While side A (IG $\left.\mathrm{I}^{3} 253,450-425 \mathrm{BC}\right)$ is an inventory of the monetary property of Dionysos and Ikarios, side B is a deme decree concerning regulations of the deme choregia. Lines $3 \mathrm{f}$. prescribe that two choregoi were to be chosen from among not only the deme members, but also the deme residents who had not performed this liturgy before. The author rejects the identification of the choregoi (lines 21, $25,32)$ with the protochoroi referred to in lines 15 and 17 . In line $12 \mathrm{M}$. reads $\mu \dot{\varepsilon} \tau \bar{o} \alpha \hat{\alpha} \alpha \dot{\lambda} \lambda \mu \alpha \tau o \varsigma$ $h \alpha \pi[\tau--]$ and suggests that this is a kind of prohibition against touching the statue (of Dionysos?). M. convincingly argues that the decree should not be dated after the beginning of the Peloponnesian War. [JM]

176) H. Malay, "A Copy of the Letter of Antiochos III to Zeuxis (209 B.C.)", in H. HeFtNer - K. TOMASCHITZ (eds.), Ad Fontes! Festschrift für Gerhard Dobesch zum fünfundsechzigsten Geburtstag am 15. September 2004, dargebracht von Kollegen, Scbülern und Freunden, Vienna, 2004, p. 407-413 [BE 2006, 411]: The appointment of Nikanor as high priest of the sanctuaries in the region beyond the Tauros in 209 BC was known from a letter of 
Antiochos III to Zeuxis found in Mysia (SEG XXXVII 1010; EBGR 1987, 67). M. publishes a new copy contained in a dossier of relevant documents found in the area of Philomelion in Phrygia. The dossier consists of the following documents (on the stone, they appear in reverse chronological order): 1) the beginning of the known letter of Antiochos to his vizier Zeuxis (lines 25-35 which correspond to the first 37 lines of the Mysian copy); 2) a letter of Zeuxis to Philomelos, probably the governor of Phrygia (lines 20-24) asking him to implement the king's order; 3) a letter of Philomelos to a subordinate official (a hyparchos?), Aineas (lines 16-19); 4) a letter of Aineas to Demetrios, possibly the official responsible for the area around the Killanion plain, with details concerning the publication of the documents in sanctuaries of the region (lines 6-18); and 5) a fragmentary letter of Demetrios (lines 1-5) to the final recipient of the dossier, i.e., a priest or a royal official responsible for the revenues of the sanctuary where the stele was erected. The most interesting section of the text is the fourth letter, which lists the sanctuaries where the kings's letter should be set

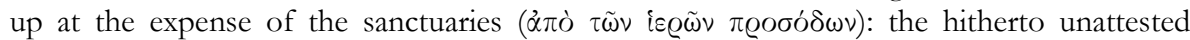
sanctuary of Aphrodite at Timis[.] enon (near Philomelion?, the site where this stele comes from?) and those of Zeus, Mes Askaenos (probably in Antiocheia; notice the unique form 'Aбxaıvós), and the Mother of Gods Tyemi[.]eia in the Killanion plain. This is the earliest evidence for the cult of Mes Askaenos. The cult was probably introduced from Magnesia on the Maiander, where it is attested, by the original settlers of Antiocheia. [AC]

177) H. Malay, "Dedication of a Herm to Zeus Ariou”, EA 37 (2004), p. 179-180 [BE 2005, 418]: Ed. pr. of a dedication known since 1976 but never published (near Kollyda in Lydia, late Hellenistic). The text is engraved on a rectangular base with a hole which originally supported a herm. Arrheidaios, son of Diokles, "of those from Kollyda", made

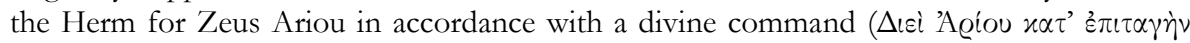

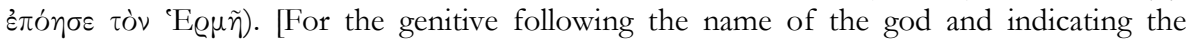
founder of the cult cf. EBGR 2000, 108 and 2003, 31]. [JM]

178) H. MALAY, “A Dedicatory Statuette of a Mother Goddess", EA 37 (2004), p. 181-182 [BE 2005, 69, 412]: Ed. pr. of a dedicatory inscription of unknown provenance engraved on the front of a flat base that served as a foot-stool for a marble statuette of a seated goddess. Philodespotos, son of Polychronios, dedicated the statue of the Mother of the God in

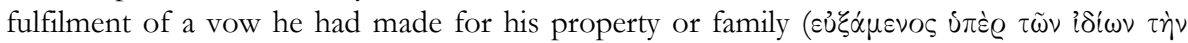

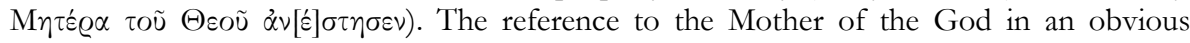
pagan context is remarkable, but there is at least one parallel from Lydia (TAM V.2, 1306)

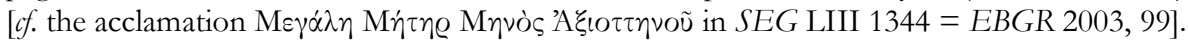
[JM]

179) H. MALAY - M.H. SAYar, "A New Confession to Zeus 'from Twin Oaks", EA 37 (2004), p. 183-184 [BE 2005, 419]: Ed. pr. of a confession inscription in a private collection in Istanbul (AD 202/3). For an unspecified reason Menophila was punished on her right

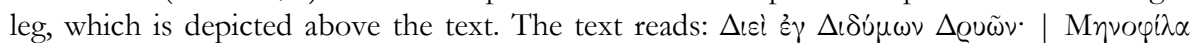

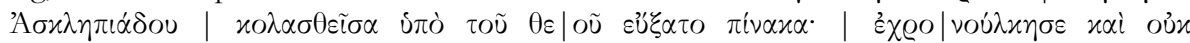

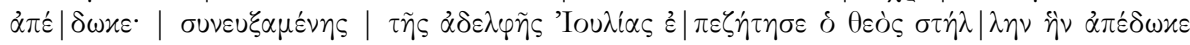

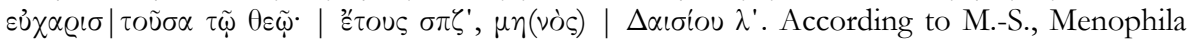
and her sister went together to the sanctuary of Zeus from the twin oaks and prayed for

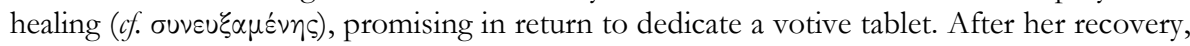
Menophila did not fulfil her vow. Zeus, therefore, requested her sister Iulia to fulfill her joint promise and dedicate a stele. [Menophila interpreted a disease as divine punishment ( pinax for her recovery, probably together with her sister. She delayed the fulfilment of her 


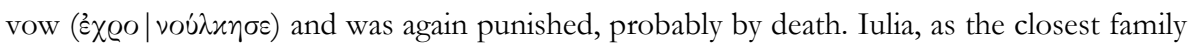
member, fulfilled the joint vow in order to avert further punishment of her family. This is an interesting example for the interdependence of dedications in fulfilment of vows and confession inscriptions (cf. supra $\left.\left.\mathrm{n}^{\circ} 44\right)\right]$. [JM]

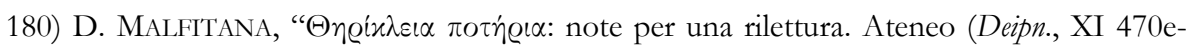
472e) e alcuni kantharoi da un santuario ciptiota", NAC 33 (2004), p. 217-247: In a

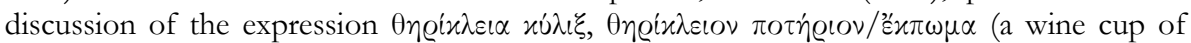

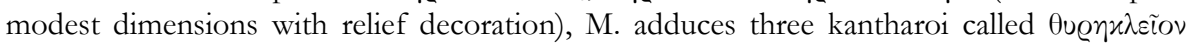
$\tau o ́ v \delta \varepsilon$ and dedicated by a potter to the Nymphs (Nú $\mu \varphi \eta \iota$ 'A $\delta \varepsilon \lambda \varphi \tilde{\eta} \iota)$ at Kafizin (Cyprus; T.B. MitTFORD, The Nymphaeum of Kafizin. The Inscribed Pottery, Berlin/New York, 1980, p. 29-32 $n^{\text {os }} 40-42$, late 3rd cent. BC; p. 236-241). M. argues that this dedication should be seen in the context of ritualised consumption of wine by the potters at Kafizin when they honoured the Nymphs with a thanksgiving dedication (a tithe). [AC]

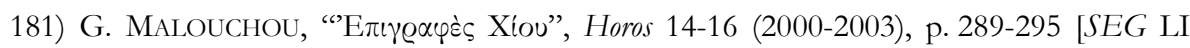
1078]: Ed. pr. of a dedicatory inscription still built into the outer wall of the castle of Chios (2nd /1st cent.). Gnosis made a dedication to Aphrodite Euploia after his term as polemarchos. This is the first attestation of the epithet Euploia for Aphrodite on Chios. [JM]

182) E. MANGO, "Bankette im hellenistischen Gymnasion”, in D. KAH - P. SCHOLZ (eds.), Das hellenistische Gymnasion, Berlin, 2004, p. 273-311 [BE 2006, 214]: Common meals seem to have had a central place in the festivals celebrated in Hellenistic gymnasia. The honorary decree for the gymnasiarchos Aglanor in Eresos on Lesbos (IG XII Suppl. 122) mentions the banquet funded by him during the Hermaia. The decree of Aigiale concerning the funerary foundation of Kritolaos for his dead son (IG XII.7, 515) [cf. supra $\mathrm{n}^{\circ} 109$ ] contains regulations about the sacrifice of an ox and a common meal at the gymnasion. Such banquets in the gymnasia were not exclusive events: the honorary decree for Elpinikos in Eretria (IG XII.9, 234) refers to the participation of other Eretrian citizens, foreigners, and Romans in the banquet in the gymnasion during the Hermaia. [JM]

183) A. Mastrocinque, "The Divinatory Kit from Pergamon and Greek Magic in Late Antiquity", JRA 15 (2002), p. 173-187 [BE 2003, 141]: An assemblage of objects related to divination was found in 1886-1898 in Pergamon (late 3rd cent. AD). It consists of three polished stones inscribed with magical texts and charakteres; a rectangular bronze plaque with magical symbols; a bronze nail; two bronze rings; a triangular bronze base with images of Hekate, magical words, groups of vowels, charakteres, and magical names of Artemis, Persephone, Hekate, and (Artemis) Leukophryene (a similar base was later found in Apameia; G. DONNAY, "Instrument divinatoire d'époque romaine", in J. BALTY [ed.], Apamée de Syrie, Brussels, 1984, p. 203-207); and a small bronze disk with magical symbols. The assemblage was interpreted by R. WÜNSCH (Antikes Zaubergerät aus Pergamon, Berlin, 1905) as a single kit used for private divination, for which he found a close parallel in the divinatory ritual performed by Hilarius and described by Ammianus Marcellinus (XXIX 1, 29-32). Accepting Wünsch's reconstruction of the divinatory procedure, M. places this kit in the religious context of late-antique theurgy and the Neoplatonic school in Pergamon under Iamblichos and Maximos. He interprets the bronze disk as a representation of the universe based on Platonic ideas; this disk, placed on the triangular base, operated as a theurgic iyn $x$ for evoking gods. Images of an animal-headed god represented with a whip, an allusion to the Egyptian creator god, are connected with theurgical practices and with the theurgists' intention to move the world through whipping [for a different interpretation see infra no 97]. [AC] 
184) A. MAstrocinque, "Magia agraria nell'impero cristiano", Mediterraneo Antico 7 (2004), p. 795-836: M. presents an impressive panorama of the use of magic for the protection of the fields in the early Byzantine period, discussing in detail several magical amulets and spells (IG XIV 2481, 2494; SEG XLIV 781; L 1014; AE 1939, 136; CIL III.2, p. 961; H. GrÉGOIRE, Recueil des inscriptions grecques chrétiennes d'Asie Mineure, Paris, 1922, no 341 ter; GuArducci, EG IV, p. 366; R. KotANSKy, Greek Magical Amulets, Opladen, 1994, p. 52f.). [AC]

185) A.P. MatThaiou, "Eic IG I3 130", Horos 14-16 (2000-2003), p. 45-49 [SEG LI 31]: IG I3 338 lines 153f. (429/8 BC) attests undoubtedly the existence of a sanctuary of Apollon Delios at Phaleron [ $c f$. infra $\mathrm{n}^{\circ}$ 186]. Another fragmentary inscription (IG I3 130, c. 430 BC) has been associated with this sanctuary. However, this attribution is based on a questionable

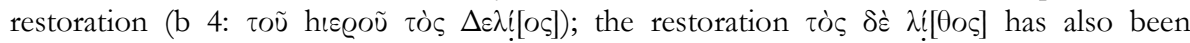
suggested. After autopsy of the stone, $\dot{M}$. rejects both restorations and suggests restoring $\tau$ tò $\varsigma$ $\delta$ ' $\varepsilon \lambda \lambda[\mu \varepsilon v \iota \sigma \tau \dot{\alpha} \varsigma]$. The enlimenistai, the customs officials of the harbour, were to pay a certain amount from the customs to an unknown sanctuary. [JM]

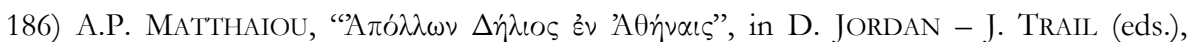
Lettered Attica. A Day of Attic Epigraphy. Proceedings of the Athens Symposium, 8 March 2000, Athens, 2003, p. 85-92: The cult of Apollon Delios in Attika is attested from the Archaic period onwards, in Prasiai (IG $\mathrm{I}^{3} 1018$ ter), in Phaleron (IG $\mathrm{I}^{3} 383,429$ BC), and in the city of Athens (K.S. PITTAKIS, L'ancienne Athènes, Athens, 1835, p. 473; of. IG II $^{2}$ 1990, 2472, 3271, 3535, and 5052). A possible location of the cult place of Apollon Delios in the city may be inferred from the discovery near the Olympieion of four inscriptions related to the sanctuary of Apollon in Delos ( $I G \mathrm{II}^{2}$ 1635, 1678 a; an unpublished account of the Amphiktyones; an unpublished inscription mentioning money payment by the Chians to the sanctuary of Apollon in Delos through the mediation of the Athenians in c. 377 BC); two of them bear inscriptions mentioning victors at the Thargelia, a festival of Apollon. The context of discovery as well as the Delian associations of the Thargelia and of Apollon Pythios lead M. to the assumption that Apollon Delios was worshipped in the Athenian Pythion, whose exact location still remains unknown. The restoration of the epithet of Apollon Delios in $I G \mathrm{I}^{3} 130$ is doubtful. [AC]

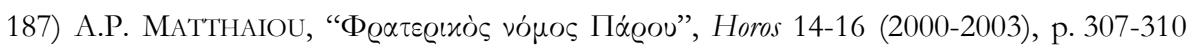
[SEG LI 1071]: Ed. pr. of an Archaic marble stele (late 6th cent.) of unknown provenance kept in the museum of Paros. The inscription is a phratry law regulating burial practices, the first direct attestation of a phratry in Paros. The phratry forbade the burial of a larnax or of bones as well as the erection of a grave monument on the cremation place defined by

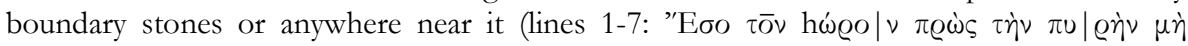

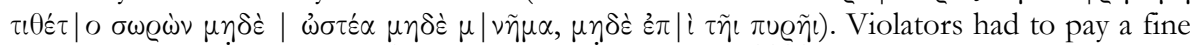
of 500 drachmas to any member of the phratry who wished to exact the fine (lines 7-15: h|o

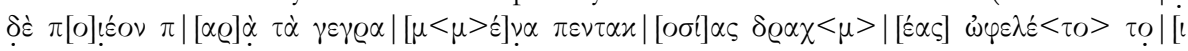

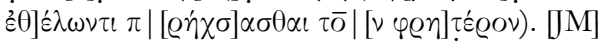

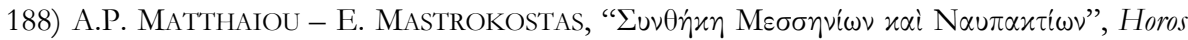
14-16 (2000-2003), p. 433-454 [SEG LI 642]: Ed. pr. of a well-known but never fully published treaty (sympoliteia?, friendship?) between the Messenians, who had been settled in Naupaktos in c. 455 BC, and the Naupaktians (Naupaktos, c. 430-420 BC). Lines 3-5 prescribe that all should descend to the sanctuary of Athena Polias $(\alpha[$ c. $14 x] \mid \alpha i$ yuv $\alpha i x \alpha \varsigma$

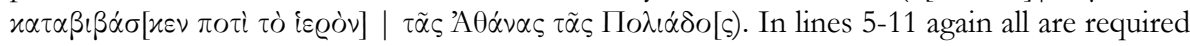
to swear that they will keep an oath (perhaps quoted in the very fragmentary opening lines of the inscription). Anyone who broke the oath was to be subject to punishment by Athena 
Polias and his belongings were to be confiscated by her sanctuary to be used for the construction of an unknown number of sphyrelata statues to be dedicated to Athena Polias

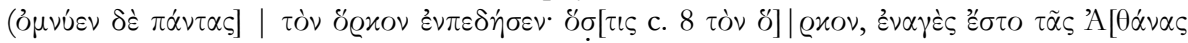

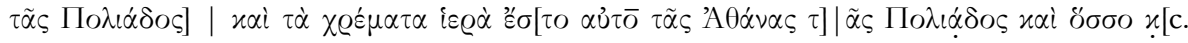

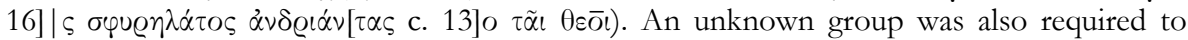

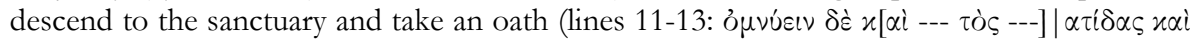

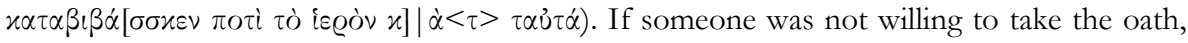
he was required to pay a fine of an unknown amount of stateres to Athena Polias (lines 13-

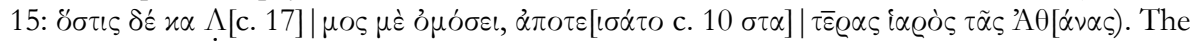
fine was to be exacted by the responsible officials; otherwise the officials themselves were to

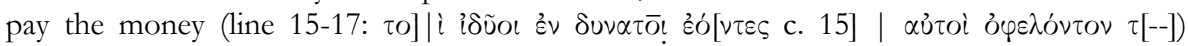
[rather: they should pay the duplum, as suggested by A. CHANIOTIS in SEG LI 642]. The rest of the inscription is too mutilated to be understood completely. M.-M. suspect that the Messenians and the Naupaktians had to renew their oath every year during the Olympic

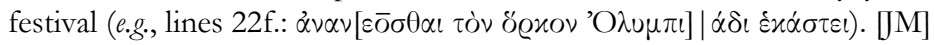

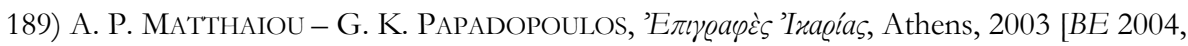
520; BE 2006, 39; SEG 888-905]: This corpus assembles the inscriptions of Ikaria [republished in IG XII.6, 1217-1292]. A fragmentary decree honours the stephanephoros Timesilaos (1*, late 2 nd cent.) who had performed a bikesia [supplicatory sacrifice followed by a banquet] to Artemis Tauropolos, inviting all the citizens and their families to the banquet. The sanctuary of Artemis Tauropolos was a recipient of fines for the violation of graves still in the 4th cent. AD (39). A list of ephebes (2,1st cent. AD) is headed by three ephebes who served as priests, obviously of the divinities of the gymnasion. [As the eds. observe, the service of two sets of four brothers shows that the ritual of the ephebeia was not annually performed in this small community; it seems that it was practiced whenever there were enough young men near the ephebic age]. There are a few dedications to Poseidon Helikonios (6*, 2nd cent.) and to the emperors Nerva (3), Hadrian (4*), and Antoninus Pius $\left(5^{*}\right)$. [A funerary epigram $\left(15^{*}, 2\right.$ nd cent.) refers to the establishment of a heroic cult for a man: "[---] set up a monument for Aphrodisios, for the sake of gratitude and memory, his father and his mother and Lampragores, the brother, establishing a godlike

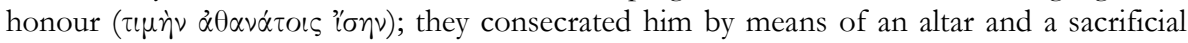

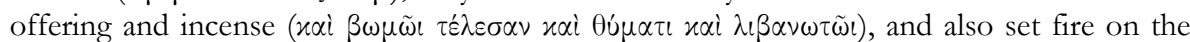
altar, as reward for the benefaction and the honour which he had shown to them when he used to see the sun's light"; the meaning of $\tau \varepsilon \dot{ } \lambda \varepsilon \sigma \alpha \nu$ (consecrated) was recognized by W. Peek (in his notebook, now in Berlin)]. In a grave epigram Persephone, Ge, and Hermes are asked to send the deceased man to the place of the pious (18*, 1 st cent. AD). [The eds.

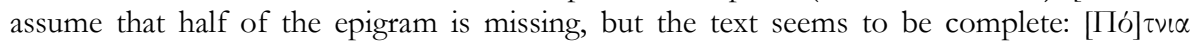

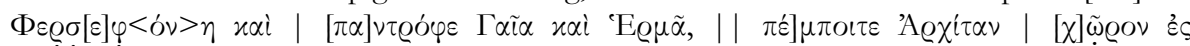

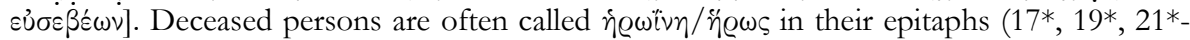

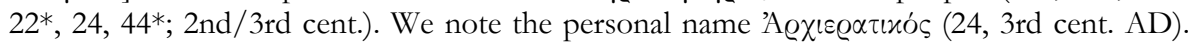
Among the Christian texts we mention the first epigraphic attestation of a Pythian oracle quoted by Christian authors from the mid-5th cent. onwards and referring to the conversion of ancient temples, those of Rhea in Kyzikos and Athena in Athens, into churches of Mary (31*, 5th cent.). The closest version to the Ikarian text is that of Johannes Malalas, Chronogr.

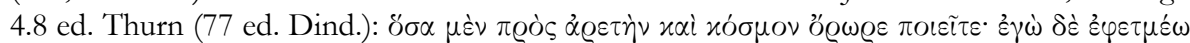

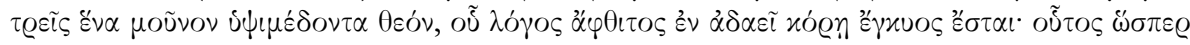

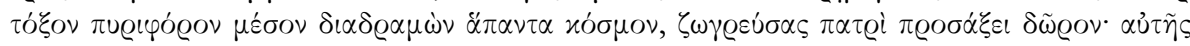

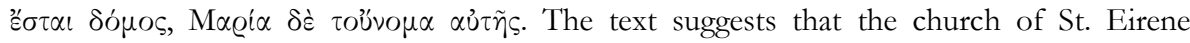


(9th/10th cent.) was preceded by an early Byzantine basilica dedicated to Mary, and this again by a pagan temple of a goddess. [AC]

190) E. MiRAnda, "Dioniso Kathegemon a Hierapolis di Frigia", in Epigraphica - Guarducci, p. 165-176: In a commentary on a dedication to Dionysos Kathegemon (Hierapolis, 2nd cent. AD), M. discusses in detail the popularity of this cult in the Attalid kingdom and the significance of the epithet $\alpha \theta \eta \gamma \varepsilon \mu \omega \dot{\omega} \nu$ (leader, the one who leads the people to victory) for a divinity who was regarded as the patron of the Attalids. [AC]

191) J. Moralee, For Salvation's Sake'. Provincial Loyalty, Personal Religion, and Epigraphic Production in the Roman and Late Antique Near East, New York/London, 2004 [BE 2006, 436]: M. dedicates this study to a particular type of dedications, widely attested in the Roman East: dedications $i \pi \grave{\varrho} \varrho \sigma \omega \tau \eta \varrho i \alpha \varsigma$ of emperors. M. plausibly argues that these dedication were an expression of an ideology of salvation, loyalty, and reciprocity: dedications for the salvation of the emperor were made in expectation of the salvation of the empire through the emperor. When the same formula was used for dedications made for the personal salvation or the rescue of family members it reflected both the persistence of local religious traditions and the wish of the population to express its belonging within the Roman system. The influence of Christianity, the use of other forms of expression of loyalty (prayers and acclamations), and the transformation of imperial ideology in Late Antiquity lead to the disappearance of such dedications in the mid-4th cent. In an appendix (p. 121-181) presents a very useful catalogue of such dedications from the Near East. [AC]

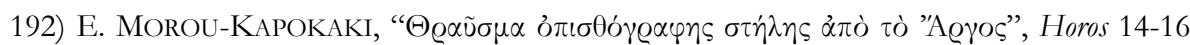
(2000-2003), p. 197-205: Ed. pr. of a fragmentary stele found in Argos in 1976, inscribed in the Hellenistic period (A, c. 250-200) and for a second time in late Antiquity. The Hellenistic text is an inventory listing metal vessels (some of them made of gold: lines 2 and 6). The inventory includes gold drink vessels dedicated by the artynai (Argive magistrates, line 16). [JM]

193) F. MosINO, "Il mito di Alcesti in un'iscrizione di Fere (Tessaglia)", MEP 5 (2001),

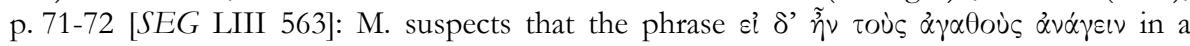
funerary epigram at Pherai (IG IX.2, 429=GV 99, early 3rd cent.) is an allusion to the local myth of Alkestis and Admetos. [AC]

194) F. MUCCIOLI, "La titolatura di Cleopatra VII in una nuova iscrizione cipriota a la genesi dell'epiteto Thea Neotera", ZPE 146 (2004), p. 105-114: A Cypriote dedication (SEG XLVII 1866, 43/2-37/6 BC) attests the title Thea Neotera for Kleopatra VII, a title already

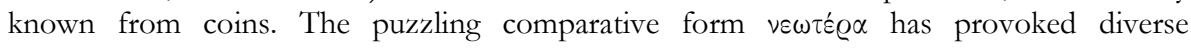
explanations. According to M. the title had already emerged under Caesar and should be connected with the erection of a gold statue of Kleopatra in the newly founded temple of Venus Genetrix (App., B.C. II, 102, 424; Cassius Dio LI, 22, 3). Thus, Kleopatra VII was celebrated under the title Thea Neotera in direct association with Venus Genetrix. Since Venus Genetrix was considered a more recent form ( $v \varepsilon \omega \tau \varepsilon \varrho \alpha$ ) of Aphrodite/Venus, the title

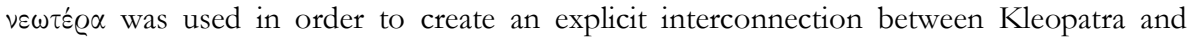
Venus Genetrix. [JM]

195) D. MusTi, "Questioni pausaniane e delfiche. L'anfizionia in età romana”, RFIC 129 (2001), p. 465-493 [BE 2005, 243; SEG LIII 482]: Critically reviewing recent studies on the Delphic Amphictyony (EBGR 1998, 160; 2001,163), M. discusses the composition of the Amphictyonic council from Augustus to Hadrian and proposes a reconstruction of the composition of the council according to Pausanias (X 8, 1-5) [cf. ID., "L"ora' di Pausania. Sequenze cronologiche nella Guida della Grecia (sull'Anfizionia di Delfi e altri argomenti)", 
in D. KNOePfler - M. PiÉRART [eds], Éditer, traduire, commenter Pausanias en l'an 2000, Geneva, 2001, p. 43-78). [AC]

196) A.N. NAgY, "Figuring out the Anguipede ('Snake-legged God) and his Relation to Judaism", JRA 15 (2002), p. 159-171: N. dedicates this excellent study to the interpretation of an iconographic scheme found in magical gems: a figure with the head of a cock, the torso of a man, and two coiled snakes as legs; he holds a whip and a shield usually with the Trigrammaton ('I $\alpha \omega)$; the image is often accompanied by magical names, usually 'A $\beta \varrho \alpha \sigma \alpha \xi$. This scheme is unparalleled in Greek, Roman, or Egyptian art and never described in literary sources. After a critical review of earlier interpretations, N. recognises in the Hebrew root $g b r$ a single ordering principle that made possible the juxtaposition of all these elements (cock, man, warrior, divine name, snakes, whip). This root and its derivatives are related to the semantic field of divine strength and might. The parts of the image evoke variants of this root and express different aspects of the name of the God of Israel: cock's head (gever), male body (gever), cuirass (gibbor), snake's legs (gibbor, of. $\gamma^{\prime}(\gamma \alpha \varsigma)$, might (gvurah), triumph (gavar). The whip alludes to the figure of a punishing god. This image did not represent the God of Israel, but a single name of God. This scheme seems to be a 'syncretistic creation', created with knowledge of the Jewish tradition, perhaps by a Hellenised Jew who no longer found himself bound by the letter of Jewish law. The creator of this image first defined one of the names of God (Gibor or ha-Gvurah) by means of words etymologically related to it and then translated these words into the contemporary iconographic vocabulary. Such etymological relationships were widely practiced. [A good example is offered exactly by $\mathrm{A} \beta \varrho \alpha \sigma \alpha \dot{\xi}$ which is

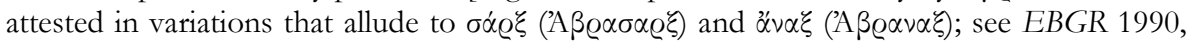
102 and 1998, 22]. The Anguipede was probably conceived as a solar deity. [AC]

197) G. NeumanN, "Beiträge zum Lykischen VIII”, Historische Sprachforschung 115 (2002), p. 57-58 [SEG LIII 1505]: A dedication to Zeus Alsenos at Phyteia in Phrygia (early 3rd

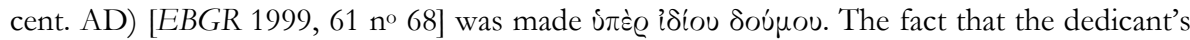

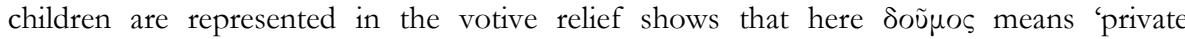
household' ('private Hausgemeinschaft') [cf. supra no 98]. [AC]

198) A. Neumann-Hartmann, 'Der Paian des Philodamos an Dionysos und der Ausbruch des 4. Heiligen Krieges', $M H 61$ (2004), p. 9-31 [BE 2005, 235; SEG LIII 488]: N.-H. summarizes the earlier research on the hymn of Philodamos on Dionysos in Delphi and discusses its content in the context of the political situation before the outbrake of the Fourth Sacred War (339 BC). She argues that the first part of the hymn associates Dionysos with places that played an important part in the Amphiktyonic Council (Thebes and Orchomenos in Boiotia, Euboia, Phokis, Eleusis in Attica, Thessaly, and Mt. Olympus in Macedonia), assigning Thebes a prominent position and attempting to unite the Amphictyony through the myth of Dionysos. The second part of the hymn aims at establishing Dionysos' cult in Delphi; this cult was introduced upon an initiative of the Amphictyonic council and the priests at Delphi. Assuming that the first performance of the hymn took place during the festival of the Theoxenia in the spring of $339 \mathrm{BC}, \mathrm{N} . \mathrm{-H}$. recognizes in the text allusions to the dangers the sanctuary at Delphi was facing due to the tension between Athens and Thebes and the conflict between Athens and Amphissa. She hypothesizes that the hymn aimed at reconciling Athens and Thebes through Dionysos' cult. [AC]

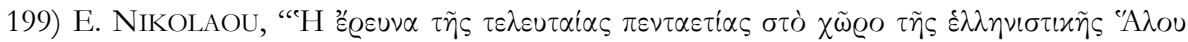

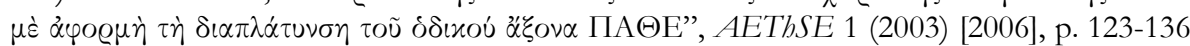
[SEG LIII 532]: Ed. pr. of a statue base recording a dedication to Demeter by a woman (Halos, 3rd cent. BC). [JM] 
200) P.E. Nulton, The Sanctuary of Apollo Hypoakraios and Imperial Athens, Providence, 2003: $\mathrm{N}$. offers a thorough and thought-provoking study of the sanctuary of Apollon Hypoakraios in 'Cave B' on the North Slope of the Athenian Acropolis. On the basis of a very well documented catalogue of all known votive plaques dedicated to Apollon Hypoakraios, N. challenges the assumption that the sanctuary already existed in the Archaic period. According to N.'s reconstruction the cult of Apollon Hypoakraios was a purely Roman creation. None of the dedications dates to a period earlier than the 1 st cent. AD. The last dedication in the cave could have been the one by the archon Dexippos ( $I G \mathrm{II}^{2} 2931$, AD 276-282). The sanctuary seems to have been used only by the members of the college of archons. Among the dedications which mention the office of the dedicant, five name an archon basileus (e.g., IG II $\left.{ }^{2} 2894\right)$, five a polemarch (e.g., $\left.I G \mathrm{II}^{2} 2915\right)$, four a secretary of the synedrion (e.g., $\left.I G I^{2} 2903\right)$, five simply an archon, probably the eponymous archon (e.g., $I G$ $\left.\mathrm{II}^{2} 2919\right)$, and sixteen a thesmothetes (e.g., $I G \mathrm{II}^{2}$ 2891). N. explains the creation of this new cult in the early 1 st cent. AD in the context of the possible assimilation of Augustus to Apollon Hypoakraios, analogous to that of Livia to Artemis Boulaia (Hesperia 6, 1937, p. 464-465, no 12). [However, there is no reference whatsoever to Augustus in the dedications connected with Apollon Hypoakraios]. [JM]

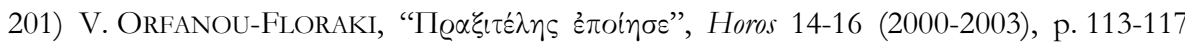
[BE 2005, 59]: Ed. pr. of a dedicatory inscription on a statue base (mid-4th cent.) found re-

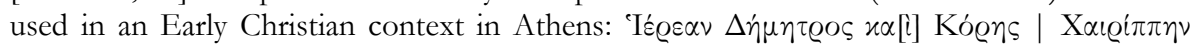

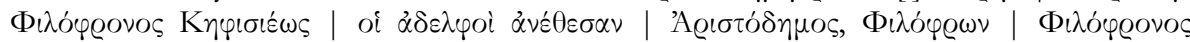

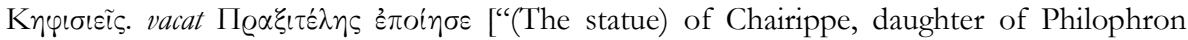
from Kephisia, priestess of Demeter and Kore, was dedicated by her brothers Aristodemos and Philophron, sons of Philophron from Kephisia. Praxiteles made (it)"']. The author suggests that the statue originally stood in the City Eleusinion. [JM]

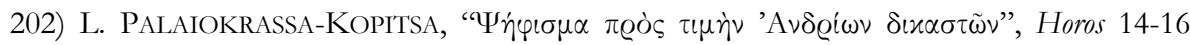
(2000-2003), p. 297-305 [SEG LI 1073]: Ed. pr. of an honorary decree found re-used during excavations in the agora of Andros. The text resembles IG XII Suppl. 258 (2nd cent.), an honorary decree of Peparethos for the demos of Andros, three judges from Andros, and their secretary. The listed honours include the announcement of the honours during the agones (line 2), references to gold crowns (lines 5, 7-8), bronze statues (lines 6, 8), and

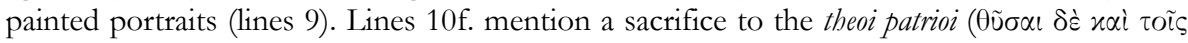
$\pi[\alpha]$ ¿Qi [oıs $\theta \varepsilon о \tilde{\imath} \varsigma])$. The decree should be erected in the most prominent place in the sanctuary of Artemis (lines 13-14). If the attribution of the decree to Peparethos is correct, this is the first attestation of a sanctuary of Artemis in this city. [JM]

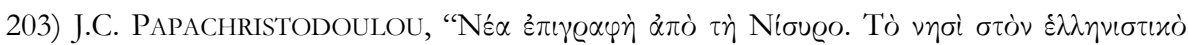

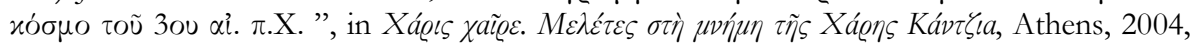
p. 435-449 [BE 2005, 378]: Ed. pr. of an honorary decree for king Demetrios Poliorketes (Nisyros, c. 301-286). It attests for the first time the month name Artamitios for Nisyros. P. presents a list of the known Nisyrian months (Artamitios, Dalios, Karneios, Sminthios). The Nisyrian calendar is close to those of Rhodes and Kos/Kalymna. [AC].

204) G. PAPASAVVAS, "A Writing Tablet from Crete", MDAI(A) 118 (2003) [2004], p. 6789: P. publishes a wax writing tablet found in 1959 in the cult cave of Eileithyia at Inatos (Tsoutsouros) in Crete (undated); the text does not survive. P. collects evidence for the dedication of wax tablets and styli in Greek sanctuaries (including a wooden board from the Heraion of Samos, p. 83) and argues that they gave the worshipper the opportunity to convey a personal message to the divinity. He also discusses the nature of the cult of 
Eileithyia and mentions a still unpublished thanks-giving dedication to Eileithyia found in

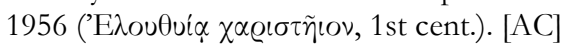

205) A. PAPATHOMAS, "Eine neue palmomantische Schrift der späteren Römerzeit: Unbekannte Fassung aus dem Melampus-Traktat?", in Paramone, 18-42: Ed. pr. of a very interesting but very fragmentary papyrus in Vienna (3rd/4th cent. AD) with a treatise concerning a particular type of divination through observation of uncontrolled movement

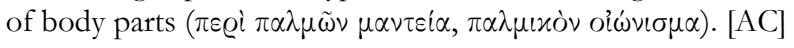

206) N. PAPAZARKADAS, "Notes on Inscriptions from Attica and Oropos", ZPE 149 (2004), p. 69-70 [BE 2005, 199]: The final lines of a badly preserved decree from Rhamnous (I.Rhamnous 63, 4th cent.) should be restored as follows, so as to correspond to the correct

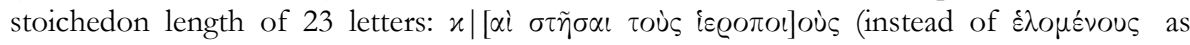

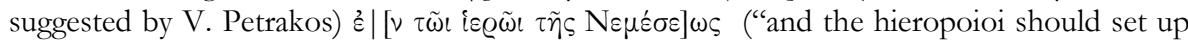
(the stone stele) in the sanctuary of Nemesis"). Exactly the same wording appears in another deme decree from Rhamnous (I.Rhamnous 15). [JM]

207) R. PARKER, “The Problem of the Greek Cult Epithet”, OpAth 28 (2003), p. 173-183: After underlining the importance of cult epithets in Greek religion, P. surveys a large number of epithets in inscriptions and literary sources arguing that they primarily fulfilled two functions: they identified the aspect of a deity that was relevant in a specific situation; and they differentiated between cult sites (esp. epithets that derived from place names). Subforms of the two types are, e.g., epithets that commemorated an intervention of a deity in a particular function (e.g., Artemis Aristoboule), alluded to the social group within which a god was worshipped (e.g., Artemis Boulaia, Zeus Phratrios, perhaps Zeus Stoichaios), propitiated a god (e.g., Eumenes, Meilichios, Doritis), diverted him from the attitude expressed in the epithet (e.g., Zeus Maimaktes), and referred to festivals and rituals (e.g., Dionysios Theodaisios, Demeter Megalartos) or to the origin and basis of a cult (Artemis Pythochrestos, Dionysos Demoteles). Even epithets with an obscure meaning (e.g., Apollon Delphinios, Lykeios, and Maleatas) referred to a recognizable identity. Briefly addressing the problem of the unity of the divine figure who lies behind the epithet, P. observes that this depends on the context. $[\mathrm{AC}]$.

208) D. Peppas-Delmouzou, "Il quadro storico-religioso dell'altare di Brauron", in Epigraphica - Guarducci, p. 91-106 [BE 2004, 68]: P.-D. reconsiders a round altar found in Brauron (SEG XXXV 27; IG I ${ }^{3}$ 1407bis) decorated with the images of gods and personifications some of which are identified with labels as Eirene, Dionysos, Hermes, and Leto; the identification of other figures is uncertain because of the fragmentary state of the texts. In the ed. pr. W. Fuchs had suggested identifying them with Ariadne and Theseus, $[\Theta \varepsilon \omega \varrho] i \alpha$ (or Eủvouia (E. SIMON, "Eirene und Pax. Friedensgöttinnen in der Antike", SB der Wiss. Gesell.

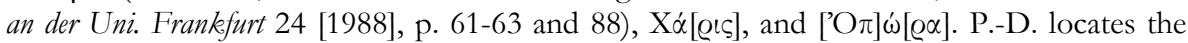
scene in Delphi, identifies three unlabelled figures as Apollon, Pythia, and Agon, and

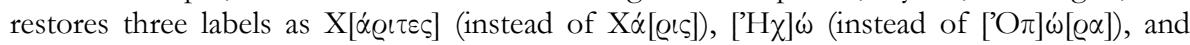
$\left[\sum \varepsilon \mu \varepsilon^{\prime}\right] \lambda \eta$. She dates the altar in the early 4th cent. (not late 5th cent.) and associates it with the festival of Eirene established in Athens in 374 BC (SEG XVI 55 + XXIX 88). [AC]

209) D. Peppas-Delmouzou, "Dédicace d'une mesure à grains par deux astynomes (IG II 2 3939 + 2878) et la politique de l'annone à Athènes sous Auguste", in L'hellénisme d'époque romaine, p. 121-138: IG II 3939 and $I G \mathrm{II}^{2} 2878$ belong to the same monument, a measuring

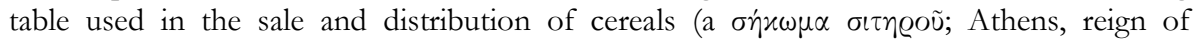
Augustus). The sekoma was dedicated to an anonymous deity by two men after the end of their term as astynomoi. [JM] 
210) D. Peppas-Delmouzou, “'Zu den Urkunden dramatischer Aufführungen’ III”, in Attikai Epigraphai, p. 75-83: The author repeats suggestions she had already made in earlier studies based on the work of A. Wilhelm. The three non-joining fragments $I G$ II $^{2} 3111 \mathrm{a}+\mathrm{b}$ and $I G \mathrm{II}^{2} 3075$ belong to a Hellenistic monument referring to the performance of old dramas during the Lenaia. IG $\mathrm{II}^{2} 2291 \mathrm{a}$ and $I G \mathrm{II}^{2} 1125$ belong together and refer to the myth of Theseus as oikistes of Athens [see supra no 84]. IG II 2325, EM 13273 and EM 13273 belong to a list of victors at the Great Dionysia and Lenaia. [JM]

211) E. PeruZZI, "Epigrafe 'pitagorica' di Gela”, PP 57 (2002), p. 384-386 [SEG LII 911]:

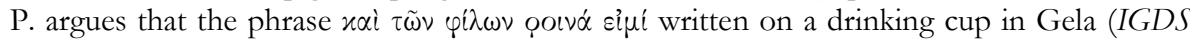
147, late 6th/early 5th cent.) is an allusion to the Pythagorean dictum nouv $\dot{\alpha} \dot{\alpha} \varphi i(\lambda \omega \nu$ that became proverbial (cf. Schol. ad Plat. Lys. 207 c; Diog. Laert., Pyth. VIII, 10). [AC]

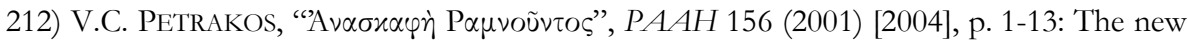
epigraphic finds in the fortress at Rhamnous (Attica) include a dedication to Asklepios and Hygieia $(10,2$ nd cent. AD). This is the first attestation of the cult of Asklepios in Rhamnous. [AC]

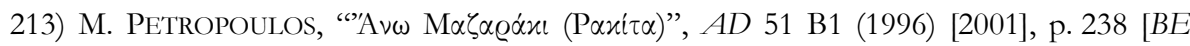
2003, 319]: A small bronze mirror dedicated by Megas to Artemis Aontia (c. 500-475 BC;

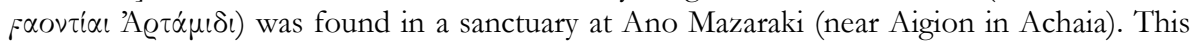
confirms the assumption that the temple, built in the Geometric period, was dedicated to

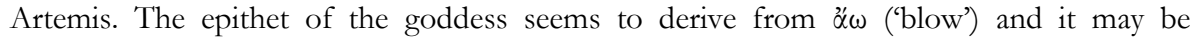
connected with the strong winds in this area. [But see S. MINON, BE 2003, 319, who associates this epithet with $\dot{\alpha} \nu \delta \dot{\alpha} v \omega(F \alpha \delta o v \tau i \alpha)$ and recognizes here a propitiatory epithet]. [AC]

214) G. PETZL, "Epigraphische Forschungsreise in Alaşehir und Umgebung", AST 19.2 (2001), p. 161-164: Ed. pr. of a text recording the construction of an altar (p. 162, Philadelpeia, undated).

215) G. PETZL, “Antiochos I. von Kommagene im Handschlag mit den Göttern. Der Beitrag der neuen Reliefstele von Zeugma zum Verständnis der Dexioseis", in Religionsgescbicbte Kleinasiens, p. 81-84: The new inscription on a black basalt block referring to the cult of Antiochos of Kommagene found in Zeugma (see supra $\mathrm{n}^{\circ}$ 57) represents a splendid example of the close interconnection between image and language. The sculptured side depicts a dexiosis scene between Antiochos and Apollon. Lines 22-23 of the inscription on the back side of the block explicitly refer to the assistance which the king had often received

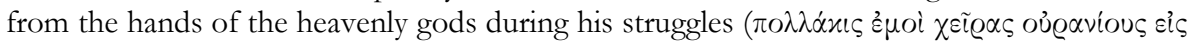

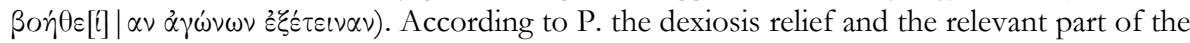
new inscription are not allusions to the enlargement of Antiochos' territory after 64 BC, but

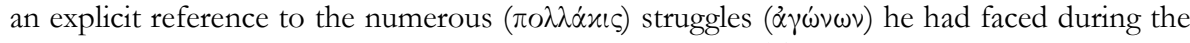
period of tension between Rome and Armenia or Parthia. The other known dexiosis reliefs of Antiochos I of Kommagene should be interpreted in the same way. [JM]

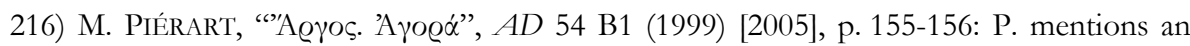
honorific inscription for the agonothetes M. Antonius Achaikos set up by the tribe of the Hyrnathioi (Argos, 2nd cent. AD). [As far as we can read the text on the photo, Achaikos was honoured as agonothetes of the Sebasteia kai Nemea for the second time; his first agonothesia is mentioned in SEG XVI $258 \mathrm{~b}$; he is praised for conducting his office $\sigma \varepsilon \mu \nu \tilde{\omega} \varsigma$

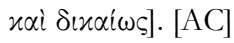

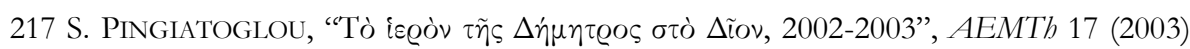
[2005], p. 425-434 [BE 2005, 312; SEG LIII 601-602]: In a brief discussion of the 
relationship between Demeter and Asklepios, whose sanctuaries were close to each other in Dion, P. (430 with note 14) mentions two dedications to Asklepios; one of them is inscribed on a statue base (early 3rd cent.), the other on a column dedicated to Asklepios Soter. [AC]

218) I. PISO, Inscriptions d'Apulum. Inscriptions de la Dacie Romaine III 5, Paris, 2001 [SEG LII 727-728]: The corpus of Apulum (Dacia) includes a few Greek dedications to Kyrios

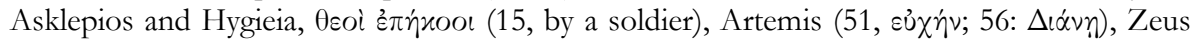
Sardendenos (229), Athena (262, by an association of sawyers), Mithras (267), Meter

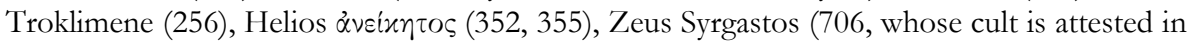

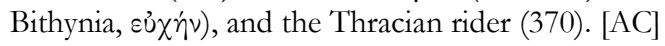

219) P. POCCETTI, "Intorno a due laminette plumbee dalla Sicilia del V secolo a.C.", Mediterraneo Antico 7 (2004), p. 615-672 [BE 2006, 513]: P. studies in great detail two lead curse tablets from Gela and Akragas (IGDS 180) which are difficult to read and interpret, and often regarded as lists of names written backwards. It is doubtful whether the text from Gela is Greek or contains Greek names. The text from Akragas may be a judicial defixio. [AC]

220) B. PUECH, "Des cités-mères aux métropoles", in L'hellénisme d'époque romaine, p. $357-$ 404: After a long discussion of the numismatic and epigraphic evidence for the honorary title of metropolis, the author attempts to define the title 'metropolis' in the Greek East during the first three centuries $\mathrm{AD}$. One of the privileges of metropoleis was apparently the organisation of panegyreis, mainly in the context of the emperor cult. The author seems to favor the idea that archiereus and asiarches designate two related, but nevertheless distinct offices [but see supra nos 40-41]. [JM]

221) G. Pugliese Carratelli, "Progressi nella lettura della lamina orfica di Hipponion", PP 57 (2002), p. 227-231: P.C. accepts the new readings of the Orphic text from Hipponion

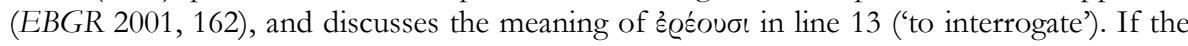

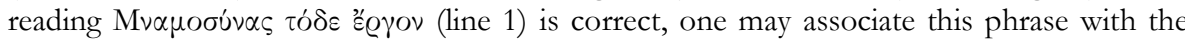
expression $\varepsilon^{\prime} v \varepsilon \varepsilon \alpha$ है $\mathrm{Q} \alpha \alpha$ in the epigram concerning the temple of Megale Meter in Phaistos (I.Cret. I, xxiii, 3). [AC]

222) G. PUGLIESE CARRATELLI, Les lamelles d'or orphiques. Instructions pour le voyage d'outre tombe des initiés grecs, Paris, 2003 [BE 2004, 10]: French revised edition of the 'Orphic' texts (cf. G. Pugliese CARRATELLI, Le lamine d'oro orfiche. Istruzioni per il viaggio oltremondano degli iniziati greci, Milano, 2001). [AC]

223) G. Pugliese Carratelli, “Dalla stipe dell'Athenaion di Ialysos”, PP 58 (2003), p. 71 73 [SEG LIII 818]: Ed. pr. of a dedicatory inscription on a bronze object (handle?) found in a votive deposit (8th-4th cent.) in the sanctuary of Athena at Ialysos [cf. infra no 224]. The dedicatory inscription (early 5th cent.) was written on the two sides of the votive object:

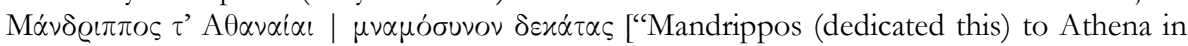
commemoration of his dekate offering." Another votive object from the same deposit (SEG

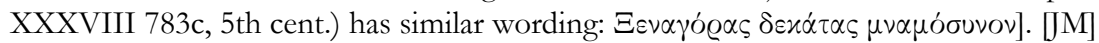

224) G. Pugliese Carratelli, "Due epigrafi dalla stipe dell'Athenaion di Ialysos", PP 58 (2003), p. 309-311 [BE 2005, 375; SEG LIII 819]: P. offers a new reading of the dedicatory

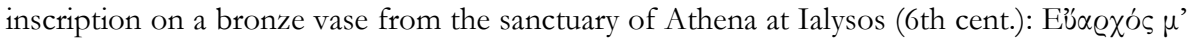

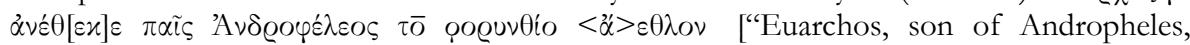

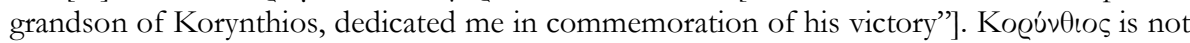
a variant of the ethnic Kogiv $\theta \iota s$, as suggested in the ed. pr., but a personal name associated with the epithet of Apollon Kó@uvOos in Asine in Messenia (Paus. IV, 34, 7). The names 
Euarchos and Andropheles suggest that Euarchos belonged to a family of Euboian origin. [JM]

225) F. Quantin, "Poséidon en Chaonie et en Illyrie méridionale", in Les cultes locaux, p. 153-178: Q. discusses the cult of Poseidon in Chaonia and south Illyria based on six dedicatory inscriptions (SEG XXIV 472, 474; XXXIV 470; XXXVIII 535, 536; XXXIX 533 ) and one sacred manumission (SEG XXIII 478) which are certainly related to Poseidon, as well as two dedicatory reliefs depicting a bull without explicitly naming Poseidon (SEG XXIV 471, 474). All the evidence seems to date to the Hellenistic and Early Imperial periods. The author rightly emphasises Poseidon's conncetion with the earth or the rivers and the importance of his cult in this region, already in the period before the appearance of the first epigraphic evidence in the 3rd cent. The brief comparison between Zeus and Poseidon is intriguing. [Nevertheless, the assumption that we may be dealing with a theriomorphic deity in the form of a bull is far-fetched. A bull-god Poseidon in Chaonia and south Illyria is as problematic as a horse-god Poseidon in Arkadia, as suggested by M. Jost; theriomorphism in myth is not to be confused with theriomorphism in cult, e.g., the horseheaded cult statue of Demeter Melaina (Paus. VIII, 42, 4]. [JM]

226) F. QUANTIN, “Artémis à Apollonia aux époques hellénistiques et romaine”, in L'Illyrie IV, p. 595-608: Q. gives a very good panorama of different aspects of the cult of Artemis in Apollonia, exploiting the dedicatory inscriptions of the Hellenistic and Imperial periods. The inscriptions attest the cults of Artemis Agrotera (primarily a huntress, closely related to Artemis Soteira and Phosphoros), Limnatis (connected with liminality and rites of passage), Adrastea (with the iconographical type of Kybele), Soteira, possibly Paidotrophos (restored in I.Apollonia 18), Proskopa (a protective deity), and Eileithyia (I.Apollonia 173) [for this text see SEG XLVII 847 (possibly Iulia or Livia identified with Eileithyia) and supra no 141]. As regards the title klakophoros (I.Apollonia 16) in the cult of Artemis Limnatis, Q. provides parallels for similar sacred functions (e.g., kleidophoros in Lagina and Epidauros, klaikophoros in Messene), but observes that they may refer to different rituals. He favours the interpretation of klakophoros as the title of the girl who carried the key of the priestess, pointing to the possible association of Artemis Limnatis with initiatory rituals for girls and to the symbolic role of the key (“symbole du passage d'un état à un autre"). [AC]

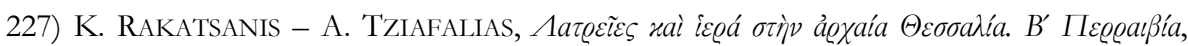
(Dodone, Suppl. 71), Ioannina, 2004: Continuing theit survey of cults in Thessaly ( $c$. EBGR 1997, 313), R.-T. present a collection of archaeological and epigraphical material related to cults, divine epithets, and sanctuaries in various cities of Perraibia in Thessaly. Gonnoi: Aphrodite, Apollon (Agreus, Aisonios, Panlimnios, Pythios) [cf. supra no 142], Artemis (Eileithyia, Euonymos, Geneteira, Heleia, Leukophryene, Lochia), Asklepios (together with Hygieia), Athena (Hoplophoros, Patroa, Polias), Enodia, Ge (Eukarpia), Herakles, Hermes (Chthonios), Isis and Sarapis, Poseidon (Gaiochos), Praxidike, Zeus (Hypsistos). Phalanna: Aphrodite, Apollon (Kerdoos), Artemis/Enodia, Asklepios, Athena (Polias), Demeter (together with Kore and Hades), Dioskouroi, Hermes (Chthonios), Kybele, Themis. Oloosson: Apollon (Pythios), Asklepios, Athena. Pythion: Aphrodite, Apollon (Doreios, Lykeios, Pythios), Artemis (Agagylaia, Eileithyia, Parthenos?, Phosphoros), Asklepios, Enodia (Patroa), Hermes (Chthonios), Poseidon (Patroos), Zeus (Kataibates, Keraunios). Azoros: Apollon (Doreios, Lykeios), Enodia (Ilias), Hermes (Chthonios). Doliche: Aphrodite, Charites, Poseidon (Patroos). Chyretiai: Asklepios (together with Hygieia). Mondaia: Themis (Agoraia). Mylai: Apollon, Meter Theon. Orthe: Athena. Elone/Leimone: Asklepios. [JM]

228) A.H. Rasmusen, "The Attalid Kingdom and the Cult of Pessinous", in K. AsCANI et al. (eds.), Ancient History Matters. Studies Presented to Jens Erik. Skydsgaard on His Seventieth Birthday, 
Rome, 2002, p. 159-164: An analysis of the fragmentary correspondence between the Attalid kings and the priests at Pessinous ( $R C$ 55-61) lead R. to the conclusion that the relations between the two parties were based on reciprocity and a close interdependence of the political and religious spheres: the Attalids had created the grandeur of the sanctuary ( $c$. Strabo XII, 5, 3) and expected in return loyalty, expressed through sacrifices for the success of the Attalids (e.g., RC 59). [AC]

229) K.J. Rigsby, "Claudius at Delphi”, ZPE 146 (2004), p. 99-100 [BE 2005, 240]: A Delphic inscription records the manumission of a female person, who was later freed from the paramone condition and acknowledged by her former owner as a daughter (SEG LI 606; EBGR 2001, 106). For the second legal act several witnesses are named, who were identified in the ed. pr. as theos Claudius (the emperor), two priests of Apollon, and three other citizens. This interpretation was accepted in BE 2002, 213 [but rejected by A. CHANIOTIS in SEG LI 606]. According to the convincing arguments of R., the word o $\theta \varepsilon o ́ \varsigma$ does not refer to the still living emperor, but to the divine owner of the sanctuary, the Delphic god. The

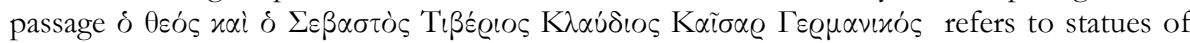
Apollon and Claudius standing somewhere in the Delphic sanctuary (not in the temple) witnessing the legal recognition of a daughter. [JM]

230) K.J. Rigsby, "Theoroi for the Koan Asklepieia”, in The Hellenistic Polis of Kos, p. 9-14 [BE 2005, 379; SEG LIII 849]: R. republishes a fragmentary Hellenistic Koan decree

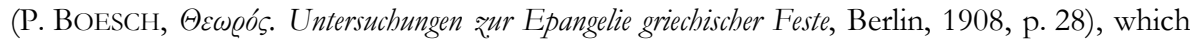

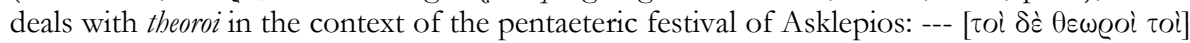

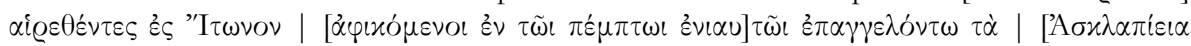

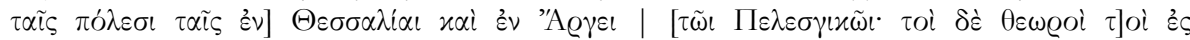

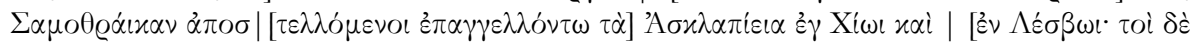

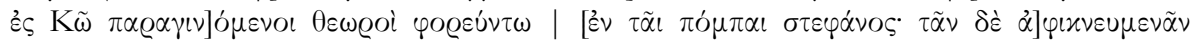

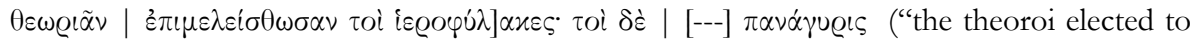
go to Itonos are every fourth year to proclaim the Asklepieia to the cities in Thessaly and in Pelasgian Argos [see also supra no 108]; the theoroi sent to Samothrace are to proclaim the Asklepieia in Chios and Lesbos. The theoroi who come to Kos are to wear crowns in the procession. The bierophylakes are to take care of the arriving theoric missions"). This decree has always served as an argument that the festival of Athena at Itonos was a Panhellenic one by 242 BC. R. rejects the assumption that this Thessalian festival ever had Panhellenic status and suggests that Koan theoroi attended the festival because of the special relationship that existed between Kos and the Thessalians. According to R., Pelasgian Argos does not designate a city but Phthia or Achaia Phthiotis (cf. Iliad II, 680ff.); the Koans used an archaic formulation from the Homeric Catalogue of Ships in order to stress their Thessalian origin. The theoro $i$ in line 7 were not the Koan theoroi who announced the festival but members of the invited theoriai that came to Kos. This decree does not date to the time of the first organisation of the Asklepieia but demonstrates the effort of Kos to rationally organise the theoria, connecting the theoria of the Asklepieia with other sacred embassies and reducing expenses. [JM]

231) T. RitTI, "Documenti adrianei da Hierapolis di Frigia: le epistole di Adriano alla città", in L'bellénisme d'époque romaine, p. 297-340: Ed. pr. of two letters of Hadrian to Hierapolis (AD 117 and 130). In the first letter, the emperor praises the city for its piety, thanks it for

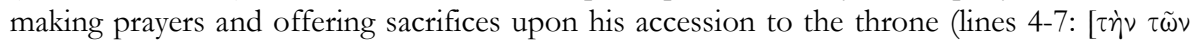

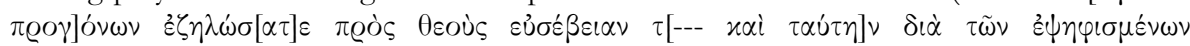

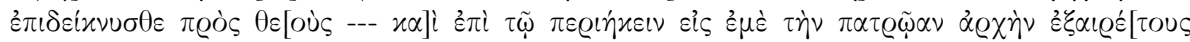

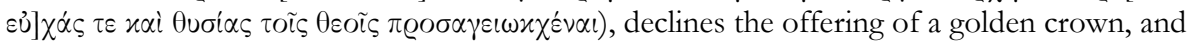


confirms the city's privileges. R. discusses the gratulatory rituals of cities upon the enthronisation of a new emperor (p. 309-311), the motif of piety (p. 316f.), and the asylia of Hierapolis (323-325). The second letter is very fragmentary; it seems to confirm some privileges. [AC]

232) N. Robertson, "The Praxiergidae Decree (IG I3 7) and the Dressing of Athena's Statue with the Peplos", GRBS 44 (2004), p. 111-161 [BE 2005, 191]: After a long and detailed discussion of $I G \mathrm{I}^{3} 7$ and some other Attic inscriptions (IG II ${ }^{2}$ 1060+1036, 1034+1943, 1942), R. proposes new restorations of the puzzling so-called Praxiergidai decree and a new - highly hypothetical - scenario for the presentation of the peplos to Athena in the context of the Panathenaia, but also in the context of the Plynteria and Kallynteria. According to R., the Ionian festival of the Plynteria was celebrated in Athens in its traditional form down to the 5th cent. The Athenians may have added the Kallynteria to this Ionian tradition. Around the middle of the 5th cent. the dressing of the statue after the peplos had been washed became the responsibility of the Praxiergidai. IG $\mathrm{I}^{3} 7$ refers to this innovation. About the same time as $I G \mathrm{I}^{3} 7$, a new practice is introduced: A newly woven peplos was presented to Athena every four years during the Great Panathenaia. At the Plynteria and Kallynteria of the following three years the Panathenaic peplos was washed and again placed on the statue in the traditional way. In the fourth year the peplos was removed permanently and replaced by the new Panathenaic peplos during the celebration of the Great Panathenaia. R. suggests that the custom of presenting a new peplos to Athena, introduced in Athens under Perikles, derived from Central Greece, and especially from Boiotia. [JM]

233) M. RocchI, “Apollon il Maleatas del monte Kynortion”, Minos 37/38 (2002/2003), p. 419-436: R. surveys the evidence for the possible properties of the deity worshipped in Mt. Kynortion near Epidauros, known as Maleatas and later associated with Apollon Maleatas. This deity may have been regarded as a patron of hunting, music, and the education of young men, but little is known about the early history of the cult. R. adduces inscriptions that refer to the hero Malos and Apollon Maleatas in Epidauros (IG IV2 128), the cult of Apollon Maleatas in Sparta and Thera (IG V.1, 929 c; XII.3, 372), and the cult of deities or heroes by the name of Maleates and Maleatas in Athens and Sparta (IG II ${ }^{2} 4962$ line 3; V.1, 929; cf. the festival Maleateia in Sparta: IG V.1, 213 line 57). [AC]

234) C. RugGERI, Gli stati intorno a Olimpia. Storia e costituzione dell'Elide e degli stati formati dei perieci elei (400-362 a.C.), Stuttgart, 2004: The study concentrates on the political history of Elis and the surounding regions (Triphylia, Pisatis, the cities of Akroreia and Lasion, the communities of the Letrinoi, the Amphidoloi, and the Marganeis) after $400 \mathrm{BC}$, but also surveys the cults of this region based on literary sources, epigraphic material and archaeological remains. Brief chapters are dedicated to the amphictyonic sanctuary of Poseidon at Samikon (p. 96-108) [I have doubts whether this sanctuary should be identified with the Pylian sanctuary of Poseidon known from $O d$. III, 5-9, as R. seems to accept]; the fragmentary bronze plaque probably referring to the Makistian cult of Athena (SEG XXXV 389; p. 133-140); the dedication of the Alasyes and the Akroreioi at Olympia (IvO 258; p. 150153); the cult of Artemis Alpheia (p. 174-177); and the Pisatan decree granting the privileges of proxeny and theorodokia given to the Sikyonians Kleandros and Sokles ( $I v O$ 36; p. 187188). [JM]

234bis) F. RUMSCHEID, "Inschriften aus Milas im Museum Bodrum”, E $A 37$ (2004), p. 4361: R. presents 17 partly unknown inscriptions in the museum of Bodrum. We single out a grave relief for a young slave with the interesting name Prophetes (1); a small round altar dedicated to the personified Agathe Elpis (4); a fragment of a column donated by Hermias, 
a priest of Poseidon Isthmios, for the well-being of his son and his grandchildren $(5=$ I.Mylasa 338); a statue base for one of the so-called "abstractions impériales divinisées" of Augustus (8); an inscription naming Diogenes, son of Diogenes, priest of C. Marcius Censorinus (no $10=$ I.Mylasa 341); a decree referring to an unknown stephanephoros, the son of Menophilos (12 = I.Mylasa 892+893); and a fragmentary inscription referring to Zeus in the dative (a dedication?; 15). [JM]

235) L. RusCu, Corpus inscriptionum Graecarum Dacicarum, Debrecen, 2003 [BE 2006, 273; SEG LIII 735]: A corpus of 152 Greek and Greek-Latin bilingual inscriptions from Dacia. Alburnus Maior: Dedications to Zeus Narenos (3-4; no 3 by a cult association), Zeus Sardendenos (5; by a collegium), Zeus Sittakomikos (7), Zeus Kimistenos (8); an invocation to Sarapis (6; SIRIS 696). Apulum: To the inscriptions included in I.Apulum (supra no 218), R. adds dedication to Mes (23). Dierna: A phylactery (44: 'I $\alpha \omega$, 'A $\theta \omega v \alpha a i ~ \mid ~ ' I \omega$, 'I $\omega$ ) and a gold tablet interpreted as a defixio (45) [but the material (gold), the findind place (workshop), and the invoked gods $(A \delta(\omega) \vee \alpha(\iota), \theta \varepsilon o i \quad \ddot{\psi} \psi(\iota \tau \odot \iota))$ suggest that the Greek text was a phylactery; the Latin text which invokes an impure daemon against Iulia Surilla may have been inscribed later (Demon im(m)unditi(a)e te agite(t). Aeli Firmme. Ste(t) supra caput Iuliae Surillae)]. Ilisua: An altar dedicated to Asklepios and Hygieia (55). Micia: An Abrasax gem (58). Orlea: A gem with the name Abrasax inscribed twice (60). Porolissum: A dedication to Theos

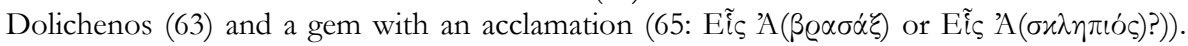
Potaissa: A dedication to Mes Aneiketos by a soldier (67) and a rare altar of the Nemeseis (73). Romula: An Abrasax gem (83); a gem with $\mathrm{A} \beta \varrho \alpha \sigma \alpha \xi$, the palindromic text $\alpha \beta \lambda \alpha \nu \alpha \theta \alpha \nu \alpha \lambda \beta \alpha$, XAPEY, I $\alpha \omega$, M $\alpha \varrho^{i} \alpha$ (103). Sarmizegetusa: A dedication of an altar to

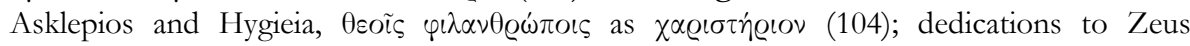

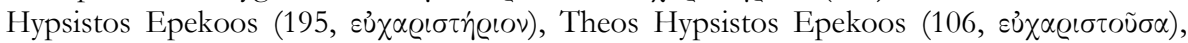

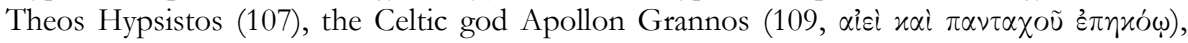
Zeus Sarapis $(110, \Theta \varepsilon \tilde{\omega} \nu \pi \dot{\alpha} \nu \tau \omega \nu$ $\varrho \alpha \tau \tilde{\omega} \nu)$. Sucidava: a dedication to the Nemesis (120), and a votive relief of the Thracian rider (121, sưn'v). Unknown provenance: several magical gems (133: Abrasax; 134: the magic word $\varphi \varrho \bullet$ written twice; 135: magical words; 136:

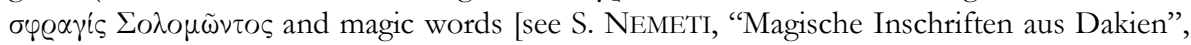

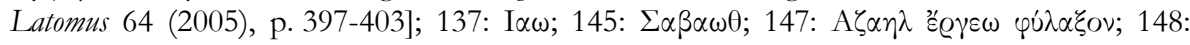

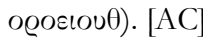

236) A.S. Rusjaeva, "The Main Development of the Western Temenos of Olbia in the Pontos", in The Cauldron of Ariantas, p. 93-116: P. presents a very useful summary of the results of the excavations in the Western Temenos of Olbia and the development of the cultic activities. She mentions numerous dedications to Apollo Boreus, Delphinios, Ietros, Targelios, and Lykeios, Meter Theon, and the Dioskouroi. [AC]

237) Vacat.

238) I. RutHERFORD, "The Keian Theoria to Delphi: Neglected Data from the Accounts of the Delphic Naopoioi (CID 2.1-28)", ZPE 147 (2004), p. 107-114 [BE 2005, 236]: The accounts of the Delphic naopoioi record not only official contributions by members of the Amphictyony for the erection of the new temple of Apollon, but also voluntary contributions both by states and individuals. R. concentrates on small contributions by individuals who apparently did not come to Delphi especially to make a donation. Interestingly, individual donors are often recorded in clusters. R. cautiously suggests that in some cases such clusters should be identified as consisting of members of or being part of the entourage of a theoria; the recorded groups of individual donors may thus reflect the presence of theoriai at Delphi. In this respect, the frequent occurrence of Keian clusters is conspicuous (CID II 6, 12,13,17, 18). Consistent with this is the fact that Keos seems to be 
one of those states most frequently receiving the priviledge of the promanteia at the Delphic sanctuary. R. suggests that there must have been a special link between Keos and the Delphic sanctuary during the 4 th and 3 rd cent. [JM]

239) S. ŞAHIN, Die Inschriften von Perge. Teil II, Bonn, 2004 (IGSK, 61.1) [BE 2005, 480]: The second volume of the corpus of Perge contains documents of the $3 \mathrm{rd}$ cent. AD, epitaphs of the Imperial period, and varia. The numerous new texts are marked with an asterisk. Priesthoods: An epitaph mentions a priest of Nemesis Enodia (*366). A priest (of an anonymous deity) for life gave the gerousia 600 denarii for the priesthood; his wife was priestess of Demeter for life (427). Dedications: Statuettes of Eros were regularly dedicated to Artemis (299: $\tau \tilde{\eta} \iota[\theta \varepsilon] \tilde{\omega} \iota)$ and the Fatherland by active and former agoranomoi $(* 303$, *306308 , of. $* 305, * 307 a)$. Other dedications are addressed to Hosios kai Dikaios (309), and

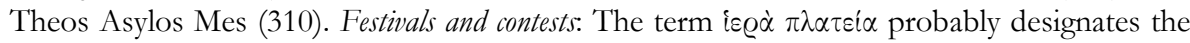
processional street leading to the temple of Artemis (and the inhabitants of this quarter; *322). Agonistic inscriptions mention the following festivals in Perge: Augoustia Olympia

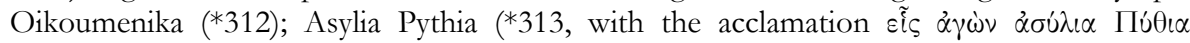
modelled on the acclamation $\varepsilon \tilde{i} \zeta$ $\theta \varepsilon o ́ c ;$ [ $c f$. the acclamation for the benefactor Epameinondas

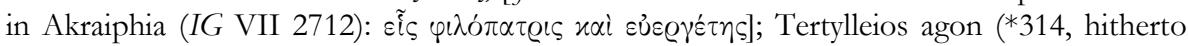
unattested, founded by a Tertullus and celebrated at least twice); the enneateric Patrios Megale Themis $(* 315, * 317$, probably identical with Themis Ouareios in I.Perge $128 ; * 317$ mentions its 8th celebration); Takitios Metropolitios Isokapetolios (*333-337); Themis é $\pi i$ $\Lambda \alpha \beta i \omega$ (*315, a contest in honour of the heros Labos, celebrated at least 9 times); agon

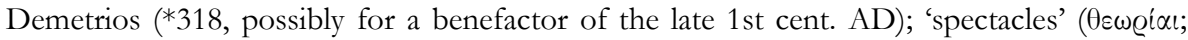
*323). The successful wrestler (bieronikes pleistonikes) L. Curius Maximianos Anatolios, who

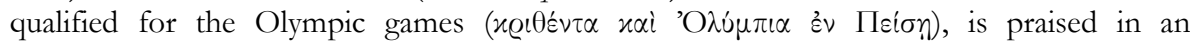
acclamation as 'the Olympian' ('O $\lambda \dot{\mu} \mu \pi i$; *314) [for a similar acclamation for an athlete with

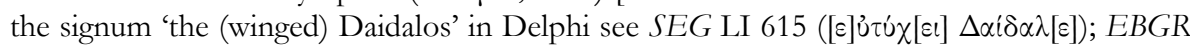
2001, 150]. An honorary epigram honours Antoninus, a priest and agonothetes (347:

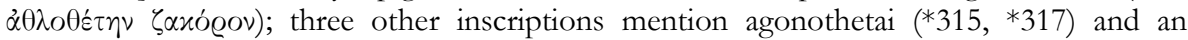

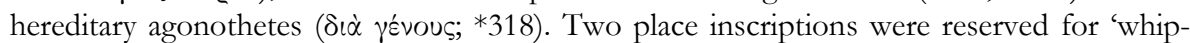

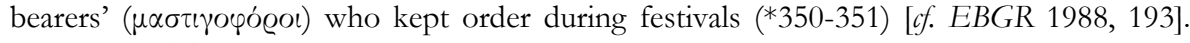
Emperor cult: The best known group of texts consists of acclamations and an enkomion for Perge after the visit of emperor Tacitus and the award of privileges in connection with the organisation of the emperor cult (331, AD 276). The enkomion, e.g., refers to the

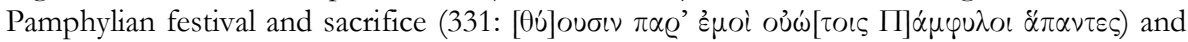

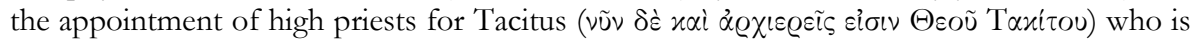

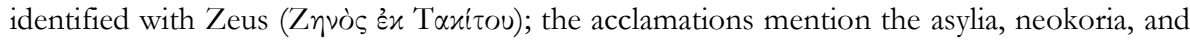
the organisation of contests by agonothetai of consular rank $(c f . * 341)$, as well as the silver coins with images of Artemis Ephesia and Artemis Pergesia. The neokoria of Perge is also mentioned in other public documents $(286, * 290,320)$. Honorary inscriptions mention a high priestess of the Sebastoi $(* 326)$ and a high priest of the Sebastoi, who organised venationes and gladiatorial games (*328). The family of a man is designated as yévos

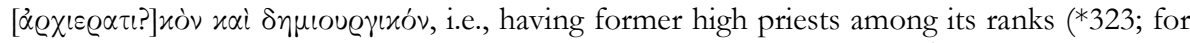
the restoration of. I.Perge 179). A dedication (*555, [a $\varphi \imath \dot{\varepsilon}] \varrho \omega \sigma \varepsilon[\nu] /[\varkappa \alpha \theta \imath \dot{\varepsilon}] \varrho \omega \sigma \varepsilon[\nu])$ was probably addressed to Hadrian. Funerary cult: Several epitaphs prescribe the sealing of the

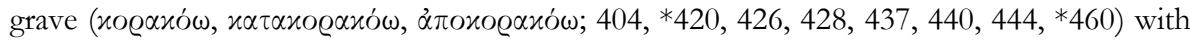

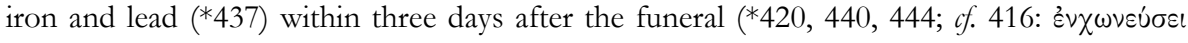

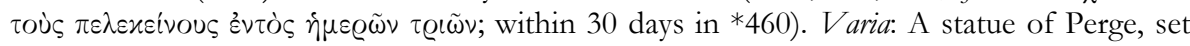
up by Fl. Parthenios, is characterised as agalma (*292, early 4th cent. AD). [AC] 


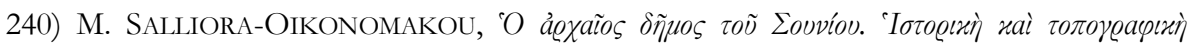

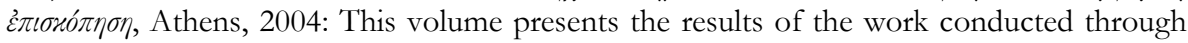
the 2nd Ephoria for Prehistorical and Classical Antiquities in the ancient deme of Sounion since 1993. Based mainly on the archaeological material, but also making ample use of epigraphical and literary sources, S. reconstructs the history and topography of the deme. [The volume offers invaluable photographic material of high quality, but the bibliographical references are kept to a minimum and only rarely go further than the mid-90's]. S. briefly discusses the attested cults and sanctuaries of: Artemis, Aphrodite, Apollon, Asklepios, Athena, Bendis, Herakles, Hermes, Hygieia, Poseidon, Zeus? (p. 115-122). The author locates the Herakleion of the Salaminioi [Agora XIX L4a = LSCG Suppl 19, 363/62; Agora XIX L4b, mid-3rd cent.] at the modern site of Pountazeza (p. 64-70). Unlike H.-R. GOETTE

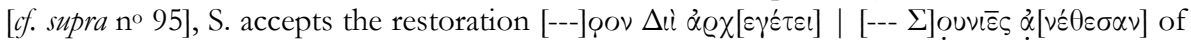
the 6th century inscription on a fragmentary thigh of a kouros from the sanctuary of Athena Sounias. In this context the author refers also to an otherwise unknown inscribed kouros fragment from the sanctuary of Poseidon [but no such inscribed fragment is mentioned in any excavation report or in the vast bibliography discussing the kouroi from the sanctuary of Poseidon]. As regards the sanctuary of Poseidon, S. uncritically follows the speculation of

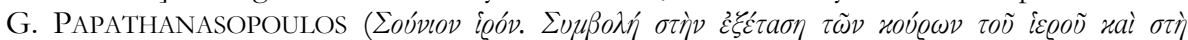

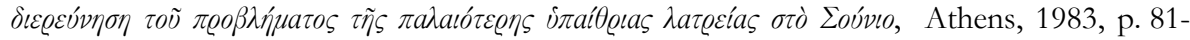
101) that in its earliest phase the sanctuary was dedicated to chthonian heroic deities. At the end of her study S. presents three invaluable catalogues listing the epigraphically attested Sounieis, members of other demes economically active in the deme of Sounion, and 153 finds from the area of the deme (dedications: 79-99, 102, 133; a lex sacra for the cult of Mes Tyrannos: 105 [= IG II $\left.{ }^{2} 1365\right]$; a calendar, possibly for the cult of Hermes: 132 [= SEG XXVI 137]). The catalogue of inscriptions contains a few inedita: a dedication to Artemis (83, 4th cent.), a dedication to Mes (87, 4th cent.), and a votive relief dedicated by Phaidros (97). [Unfortunately, there are many editorial mistakes: e.g., the photo 115 (p. 119) shows the base of a dedication to Artemis by Noumenios (4th cent.), not a dedication to Aphrodite as stated in the text]. [JM]

241) M.H. Sayar, “Two Steles Dedicated to the Twelve Gods”, Palmet 5 (2004), p. 65-68. Ed. pr. of two stelae in the Sadberk Hanim Museum from Lykia and the border of Karia and Lykia respectively. In the first stele, a central figure (the Father God) and another 12 standing youths (the Dodeka Theoi) with spears in their hands are represented in relief on the upper panel; on a lower panel twelve dogs, arranged in groups of six, flank a central figure. According to the inscription the stele was dedicated by Toalis to the Twelve Gods upon their command ( $\varkappa \alpha \tau \dot{\alpha} \varepsilon \pi \tau \tau \alpha \gamma \eta \dot{\eta} \nu)$. S. mentions a similar stele presented in the catalogue of an auction in 1997, a dedication of Onesimos to the Twelve Gods upon command. The second stele represents in the upper panel 12 gods flanking a central figure, in the lower panel 12 dogs flanking a central figure (Artemis?). The stele was dedicated to the 12 Gods, Artemis Kynegetis, and Hermes upon command (2nd/3rd cent. AD). The Twelve Gods are conceived here as hunters. $[\mathrm{AC}]$

242) A. SCHACHTER, “Tanagra: The Geographical and Historical Context. Part One”, Pharos 11 (2003), p. 45-74: S. discusses briefly a dedication found in Olympia (late 6th cent.; SEG XV 245). Because of the Attic letterforms he recognizes here a dedication of the Athenians

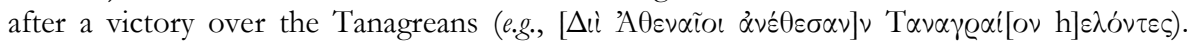
[AC]

243) A. SCHÄFER, "The Diffusion of Religious Belief in Roman Dacia: A Case-Study of the Gods of Asia Minor", in W.S. HANSON - I.P. HAYNES (eds.), Roman Dacia. The Making of a 
Provincial Society (JRA Supp. 56), Portsmouth, 2004, p. 179-190: In recent scholarship on religion in Roman Dacia Roman syncretistic tendencies have been detected in the use of epithets for Roman gods, but it has also been suggested that numerous cults reflect the religious beliefs of the native Dacians. S. focuses on the worship of gods from Asia Minor, especially Glykon in Apulum (CIL III 1021-1022), Hekate, Aesculapius Pergamenus in Sarmizegetusa (CIL III 1417a), Zeus Sardendenos in Apulum (CIL III 7762) and Alburnus Maior (SEG XXV 830), and Zeus Sittakomikos in Alburnus Maior (SEG XXV 831). S. also considers portable images of gods made by marble from eastern quarries (Prokonnesos, Naxos, Paros, Thasos, etc.; e.g. SEG LII 728) and a Dionysiac cult association in Napoca (CIL III 870; a spira with reference to Asiani). This more differentiated and contextualised approach leads $\mathrm{S}$. to the conclusion that migration and the need to preserve a cultural identity were very important factors for the diffusion of foreign cults; additional factors were propagation, imitation, and direct borrowing. [AC]

244) G. SCHÖRNER, Votive im römischen Griechenland. Untersuchungen zur späthellenistischen und kaiserzeitlishen Kunst-und Religionsgeschichte, Stuttgart, 2003 [BE 2005, 77]: This excellent study presents a systematic analysis of dedicatory practices in Greece (the area of the province Achaia) under Roman rule (ca. 2nd cent. BC-4th cent. AD). S.'s analysis is based on an impressive collection of testimonia; the catalogue lists 1240 dedicatory inscriptions (p. 224578), with description, text, and the main bibliographical references. S. discusses inter alia the dedicatory formulae (p. 11-28; terms used for dedications; reasons for the dedication); types of dedicatory objects and their iconography (p. 29-139; dedicatory reliefs, altars, objects related to sport, such as torches, tripods, sickles, plaques and stelae, statues, portraits, buildings); the dedicants (p. 141-160; gender, occupation, status, origin); the divinities to whom dedications were made (p. 161-186), the conception of man and god as revealed by the dedications (p. 187-197: Asklepios and healing deities, Zeus, Artemis, Apollon, Demeter, Kore, Athena, Hermes, Dionysos, Poseidon, Aphrodite, Hera, Ares, Hestia, Herakles, Dioskouroi, Helios, personifications, the emperors, oriental and Egyptian gods, heroes); archaistic tendencies (p. 199-209); and aspects of Romanisation and cultural memory (p. 211-224). [AC]

245) G. SCHWEndner, "Under Homer's Spell. Bilingualism, Oracular Magic, and the Michigan Excavation at Dimê", in L. CiRAOLO - J. SEIDEL (eds.), Magic and Divination in the Ancient World, Leiden, 2002, p. 107-118: A study of papyri found in secured contexts in Soknopaiou Nesos (Dimê), in a bilingual Demotic-Greek milieu, shows the practice of Homeromanteia (the use of Homeric verses for divination) and a significant penetration of Greek culture into Egyptian culture (3rd cent. AD). Because of the collapse of the temple system, traditional divination was replaced by book-divination. [AC]

246) G. SFAMENi GASPARro, "Iside salutaris: aspetti medicali e oracolari del culto isiaco tra radici egiziane e metamorfosi ellenica", in N. BLANC - A. BUISSON (eds.), Imago Antiquitatis. Religions et iconographie du monde romain. Mélanges offerts à Robert Turcan, Paris, 1999, p. 403-415 [BE 2003, 87; SEG XLIX 2479]: S.G.'s study of the medical and oracular aspects of the cult of Isis considers several inscriptions, esp. the aretologies of Isis (W. PEEK, Der Isishymnus von Andros und verwandte Texte, Berlin, 1930; SIRIS 88 line 11) and the hymns of Isidoros at Medimet Madi (BERNAND, Inscr. métriques 175). Her medical properties are well attested in Delos, where she was worshipped as Hygieia and received iatra. [AC]

247) P. SIEWERT, "Die wissenschaftsgeschichtliche Bedeutung der Bronze-Urkunden aus Olympia mit der Erstedition einer frühen Theodorokie-Verleihung", in H. KYRIELEIS (ed.), Olympia 1875-2000. 125 Jahre Deutsche Ausgrabungen. Internationales Symposium, Berlin 2000, Mainz, 2003, p. 359-370 [BE 2005, 222]: Up to now, 51 bronze inscriptions have been 
unearthed during the excavations at the sanctuary of Olympia; half of them (26) are sacred regulations. Nine bronze inscriptions are Eleian documents of both religious and political character, among them a document from the second third of the 5th cent., which S. publishes in his article. The text is written on a bronze sheet in the form of a ring (diameter: c. $23 \mathrm{~cm}$ ). Two persons, Athanadas and Rhinos, received from the Eleians citizenship, the right to participate in the Eleian epoikiai in Sparta and Euboia, as well as the privilege of

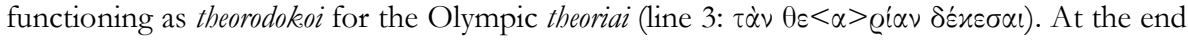
of the inscription the bronze object is characterised as a dedication to Zeus (line 4: $\delta \delta \varepsilon$

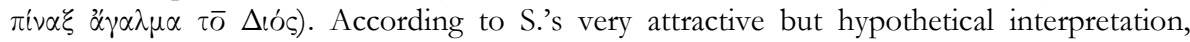
Athanadas was a native Spartan, while Rhinos came from a city on Euboia (Eretria or Chalkis). Assuming that they were priests of the local cults of Zeus Olympios in Sparta and Euboia respectively, S. reconstructs an almost panhellenic network of local priests of Zeus Olympios joined together through their function as theorodokoi for the Olympic theoriai. [JM]

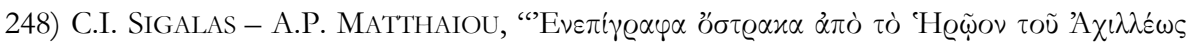

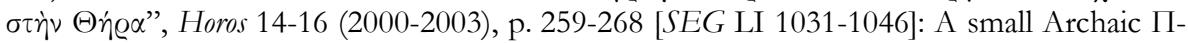
shaped edifice was excavated in the village of Kamari on Thera in 2000. 15 fragments of vases bear graffiti, three of which $(1,5 \mathrm{~d}, 10)$ allow the edifice to be identified as a shrine of

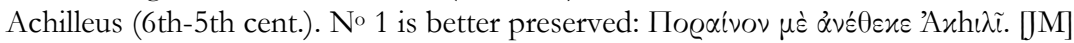

249) E. SIMON, "Heilende Heroen”, ARG 6 (2004), p. 39-43: A krater from Poteideia in a private collection shows a mythological scene, the protagonists of which are identified with labels. Phineus is seated on a throne, with Idaia at his side. Iason, accompanied by the Dioskouroi, heals Phineus of his blindness by placing his healing hands on his eyes; the Boreades and the Harpyiei are represented on the other side. S. argues that this scene was inspired by a lost epic poem about the Argonauts. With this image as her starting point, $\mathrm{S}$. comments on the motif of the healing hand ( $c f$. Cheiron/ $\chi$ si $\varrho$ and the iconography of

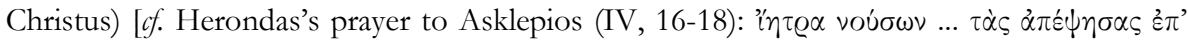

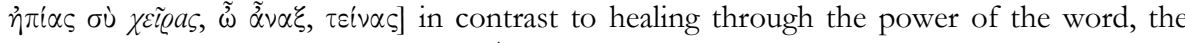
healing properties of heroes ( $c f$. Iason/i $\alpha$ for $\mu \alpha$ ), the cult of healing heroes (e.g., Asklepios) [cf. supra $\mathrm{n}^{\circ \mathrm{s}} 26$ and 101] and the snake as an attribute of healing divinities. [AC]

250) P. Sineux, "Le dieu ordonne. Remarques sur les ordre d'Asklépios dans les inscriptions de Lébèna (Crète)", Kentron 20 (2004), p. 137-146: At the sanctuary of Asklepios in Lebena (Crete) an inscription narrates a series of healings and among them, those of the Gortynian Demandros and of the wife of the Lebenean Phalaris (I.Cret. I, xvii, 9). In both cases, the healing procedure is preceded by a command ( himself: the ill person is asked to come to the sanctuary in order to be healed during incubation. M. Guarducci suggested that the divine command was received during an incubation previous to that which accomplished the healing. On the contrary, S. rightly dissociates the dreams, during which the divine command was given, from incubation. These dreams took place outside the sanctuary and were spontaneous, not "invoked" as in the case of incubation dreams. A similar case is mentioned in an inscription documenting the healing of the Troizenian Eratokles by Asklepios in Epidauros (SEG XXII 280). [JM]

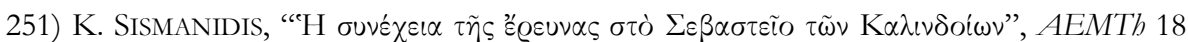
(2004), p. 213-224 [BE 2006, 253]: Excavations at the Sebasteion of Kalindoia in Macedonia have brought to light an inscription dating to $86 \mathrm{AD}$. The text reports that Mysta and her children, Isidoros and the younger Mysta, financed the erection (of part) of the Sebasteion in which statues of members of their family were dedicated. During the public inauguration of the temple the citizens of Kalindoia were implored to take care of the building. [The

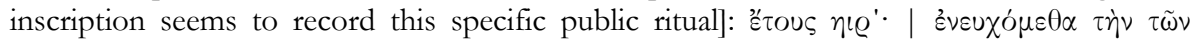




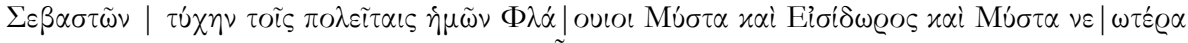

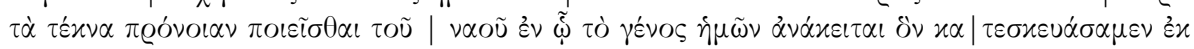

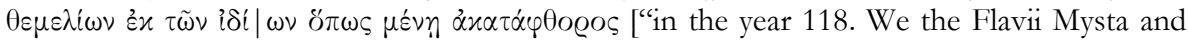
(her) children, Isidoros and Mysta the younger, implore our fellow citizens in the name of the fortune of the Sebastoi to take care of the temple in which (statues of) our ancestors have been erected and which we built up at our own expenses from the foundation, in order that it remains undestructable]. According to S., the inscription refers most probably to rooms $\Gamma$ and $\Delta$ of the cult building, since they can be dated to the Flavian period. Significantly, the inscription was found just outside room $\Gamma$ [on the emperor cult at Kilindoia see EBGR 2003, 159]. [JM]

252) O.Y. Sokolova - N. A. PAvlitschenko, "Eine neue Weihinschrift aus Nymphaion", Hyperboreus 8 (2002), p. 99-121 (in Russian; German summary) [SEG LII 741]: Ed. pr. of an inscription on an architrave which records the dedication of a propylon in the sanctuary of Dionysos (Nymphaion, c. 389-349) by an agonothetes during his term in office [for a preliminary report see EBGR 2001, 172]. [AC]

253) J.D. SosIN, "Grain for Delos", MH 60 (2003), p. 65-79 [SEG LIII 810]: Several Delian inscriptions refer to special funds for the purchase of grain (sitonia) and reveal the close financial interaction between the sanctuary of Apollon and the city, since the money was lent from the treasury of Apollon (IG XI.2, 146 A; 287 A; I.Délos 362 A; 399 A; 442 A; 301$179 \mathrm{BC}$ ). One of the relevant accounts (I.Délos $362 \mathrm{~A}$ ) refers to the temple of Artemis and

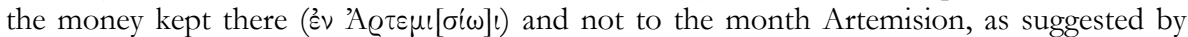
G. REGER ("The public purchase of grain on independent Delos", ClAnt 12 [1993], p. 320). S. reasonably doubts whether this account concerns an endowment or merely an one-time purchase of grain. The simple mention of sitonai (line 11) is not necessarily an argument for an endowment, as parallels from Erythrai (I.Erythrai 28, lines 20-29) and Samos (IG XII.6, 11, lines 37-49) show. [JM]

254) J.D. SosIN, “An Endowed Peace”, MH 61 (2004), p. 2-8: A fragmentary Athenian inscription dating to the Lykourgan period refers to a newly established public festival for Peace (SEG XVI 55). It seems that the new festival was intended from its creation to correlate chronologically with the Greater Panathenaia or another major Attic festival (lines

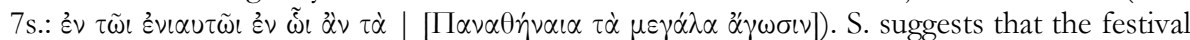
for Peace was an important part of the Lykourgan religious policy and must have been established after 'Thebes' destruction in 335. [JM]

255) C. Souli - A. Vlachopoulou - K. Gravani, "Av $\alpha \sigma \alpha \alpha \varphi \dot{\eta} \Delta \omega \delta \omega \nu \eta \varsigma ", ~ P A A H 158$

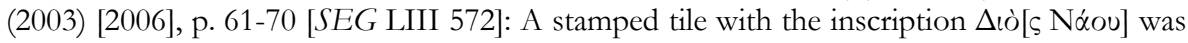
found near the prytaneion in Dodona (3rd cent.; p. 68; cf. SEG L 545). [AC]

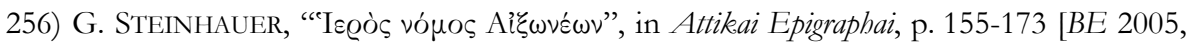
200]: Ed. pr. of the concluding fragment of a lex sacra concerning the funds provided to priests and their share of the sacrificial animal (IG II' $1356=$ LSCG 28, Athens, c. 400-375) found during street works in 1984. S. attributes it to the deme of the Aixoneis. [We provide an English translation of the text: "To the priestess of the Hagne Theos hierosyna of 5 drachmai and $1 \mathrm{dr}$. for $1 / 3$ (medimnos) of barley, $1 \mathrm{dr}$. for $1 / 6$ (med.) of grain, $1 \mathrm{dr}$. for 2 kotylai of honey, $1 \frac{1}{2}$ oboloi for 3 kotylai of oil, $2 \frac{1}{2}$ ob. for 1 chous wine, $2 \mathrm{ob}$. for phrygana and $3 \mathrm{dr}$. for wood. To the priest of the Hagne Theos the same as to the priestess and the skins of both sacrificial animals and $20 \mathrm{dr}$. (for the purchase of the animals). To the priest of Paralos bierosyna of $5 \mathrm{dr}$. and $10 \mathrm{dr}$. (for the purchase of the sacrificial animal), the skin of the sheep, $1 \mathrm{dr}$. for $1 / 6$ (med.) of grain, $4 \frac{1}{2} \mathrm{ob}$. for $1 / 4$ (med.) of barley, $1 \mathrm{dr}$. for 2 
kotylai of honey, $1 \frac{1}{2} \mathrm{ob}$. for 3 kotylai of oil, $5 \mathrm{ob}$. for 2 choes of wine and $2 \mathrm{ob}$. for phrygana. To the priest of the Archegetes and the other heroes bierosyna of $5 \mathrm{dr}$. and the skins of whatever animals he slaughters. (For a sacrifice) on the eschara $3 \mathrm{ob}$. for $1 / 12$ of grain, $1 \frac{1}{2} \mathrm{ob}$. for 3 kotylai of oil, and $3 \mathrm{ob}$. for a kotyle of honey. And when he prepares a trapeza $1 \frac{1}{2} \mathrm{ob}$. for 2 choinikes of grain, $1 \mathrm{ob}$. for 2 kotylai of oil, $1 \frac{1}{2} \mathrm{ob}$. for half a kotyle of honey, and $2 \mathrm{ob}$. for phrygana. And when one of the pentekostyes offers a sacrifice of popana in the heroa, they shall provide on the trapeza 2 choinikes of grain, 2 kotylai of oil and half a kotyle of honey"]. [JM]

257) I. ŠTEREVA, Raqkopi i Prouchivannia 28 (2001), p. 23 and 116 (ph.) [non vidimus; see N. Sharankov, AE 2003, 1567; SEG LIII 646]: Ed. pr. of a dedication to Apollon Syidenos in fulfilment of a vow by a beneficiarius (Sliven, i.e. ancient Thuidai/Syidai, area of Augusta Traiana in Thrace, 2nd cent. AD). [AC]

258) V.F. STOlBA, "Graffiti and Dipinti", in L. Hannestad et al. (eds.), Panskoye I.1. The Monumental Building U6, Aarhus, 2002, p. 228-244 [SEG LIII 792-793]: Ed. pr. of a bellshaped ritual vase with a red dipinto (Panskoye, North Shore of the Black Sea, c. 300 BC; p. 229 no. $\mathrm{H} \mathrm{1)}$; it was dedicated to Herakles and found in a monumental building near a limestone relief representing Herakles. Another kylix with a graffito $(\mathrm{H} 2=$ SEG XXXVIII 755) was dedicated to Sabazios (4th cent.). [AC]

259) J.-Y. STRASSER, "La grandre prêtrise dans trois inscriptions de Cilicie", Tyche 16 (2001), p. 189-204 [BE 2003, 542; SEG LI 1853]: According to S.'s restoration of an inscription from Anemourion (S. HAGEL - K. TOMASCHITZ, Repertorium der westkilikischen Inschriften nach den Scheden der Kleinasiatischen Kommission der Österreichischen Akademie der Wissenschaften, Vienna, 1998, no 25, Imperial period), the text does not attest a high priest of the cult of Tyche, but a

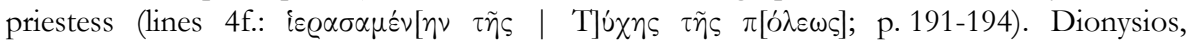
honoured as a priest of the emperor cult and agonothetes at Aigeai (SEG XXXVII 1246, 1st

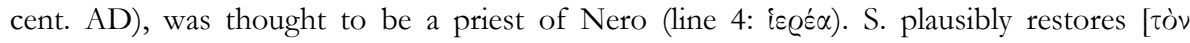

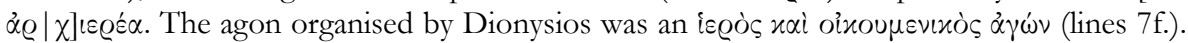
This high rank may have been awarded by Nero through the mediation of the athlete Nikostratos of Aigeai; this title was lost after Nero's damnatio memoriae (p. 194-199). An anonymous high priest and gymnasiarchos honoured in Diokaisareia (SEG XXXVII 1296, 2nd cent. AD), was not high priest of Zeus Olbios, since this title was no longer used in the 2nd cent. AD, but a high priest of the emperor cult. The dedicant, Aelius Maron, may be the famous athlete T. Aelius Aurelius Maro of Seleukeia. The honoured person may have been a

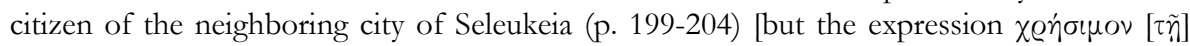
$\pi \alpha \tau$ Qi $\delta \iota$ suggests that the inscription was erected in the fatherland of these men]. [AC]

260) J.-Y. STRASSER, “Les Antôninia Pythia de Rome”, Nikephoros 17 (2004), p. 181-220 [BE 2006, 225]: The victory list of L. Sept. Aur. Markianos found in the so called Roman agora at Delphi (early 3rd cent. AD) is the only attestation of a penteteric Greek contest in Rome

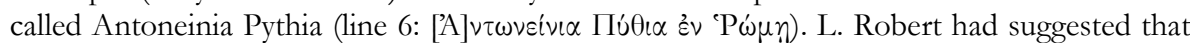
the contest was founded by Helagabalus (BE 1970, 161), but S. demonstrates that the festival must have already been founded under Caracalla, since the name Antoneiniana implies a connection with Caracalla. The first (and also the last) celebration of this contest must have taken place in AD 214. The assassination of the emperor and the troubled political situation prevented a second celebration. The discipline of Markianos is not known. The use of $\delta i \dot{\alpha} \pi \dot{\alpha} \nu \tau \omega \nu$ (lines 16-18) shows that he was an artist, while his victories at Olympia point to him being either a herald or a trumpeter (or both). S. convincingly argues that Markianos was probably a herald. [JM] 
261) J.-Y. STRASSER, "Sur une inscription rhodienne pour un héraut sacré (Suppl. Epig. Rh. 67)", Klio 86 (2004), p. 141-164: A Rhodian decree (Suppl. Epig. Rh. 67) honours an athlete from Kaisareia Panias who after the end of his career became a bierokeryx on Rhodos. The inscription dates to the $3 \mathrm{rd}$ cent. $\mathrm{AD}$, since his victories include one at the Soteria Kapitolia in Syrian Laodikeia, a contest founded after AD 197/8. The list mentions almost exclusively victories in the stadion race, and in one case a victory in the dromos boplites (line 15). It is interesting that the games of the Koina Asias at Ephesos (lines 10-12) are not designated as Ephesian; the text stresses only the fact that the games took place in the city of Ephesos. At the beginning of line $13 \mathrm{~S}$. suggests restoring $\Delta \varepsilon \varepsilon^{\alpha} \alpha{ }^{\prime} \mathrm{O} \lambda \dot{u} \mu \pi \iota \alpha$, an otherwise unattested contest

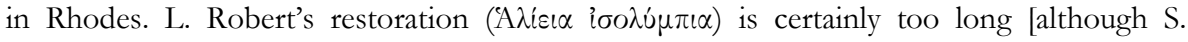
himself admits (note 50) that another possible restoration could be $A \lambda i \alpha$ instead of $A \lambda i \varepsilon i \alpha$; he dismisses this possibility because, according to his view, the iselastic Halieia would have had to be mentioned in the first eight lines together with the other iselastic games. However, since lines 12-14 refer to Rhodian games, A $\lambda i \alpha$ seems to be the correct restoration. The victory list seems to have a clear structure: the international sacred and iselastic games (lines 1-9), the Ephesian games (lines 9-12), the Rhodian games (lines 12-14), and the games at Kaisareia Panias, the home city of the athlete (lines 14-16)]. Lines 17-20 attest an exceptional gesture of piety and modesty: the athlete crowned the herms in the stadia with the crowns he had won and proclaimed as victors the demoi and the boulai of the cities where he was himself victorious. For this reason Tarsos, Antiocheia, and perhaps Laodikeia granted him citizen rights, while Kaisareia erected a statue in his honour. [JM]

262) J.-Y. STRASSER, "L'empereur $\theta \varepsilon \tilde{o}$ ' es et une inscription de Laodicée du Lykos", EA 37 (2004), p. 129-143 [BE 2005, 462]: Despite its wealth, Laodikeia/Lykos started organising sacred contests relatively late; the Deia are perhaps the best known among them (I.Laodikeia am Lykos 59). S. focuses on another inscription - now lost - referring to the second celebration of the Antonea Geteia Olympia (I.Laodikeia am Lykos 60) honouring the sons of Septimius Severus. In the very fragmentary beginning of the inscription S. plausibly restores

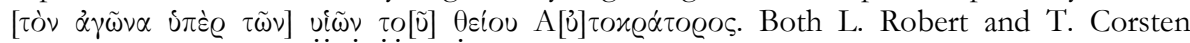

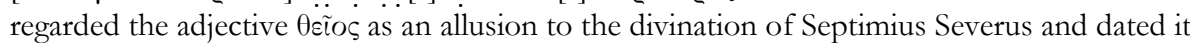
after the death of that emperor. S. demonstrates convincingly that the adjective $\theta \varepsilon \tilde{\varepsilon} 0 \varsigma$ is an equivalent of divinus and not divus and can refer to a living Emperor (IG $\mathrm{II}^{2}$ 3405, AD 165/66; I.Cret. IV 279, AD 210/11). The inscription from Laodikeia should be dated between AD 198 and 211. T. CORSTEN suggested that the Laodikeian Antonea Geteia Olympia were a penteteric festival, but $\mathrm{S}$. argues that the contest must have been trieteric.

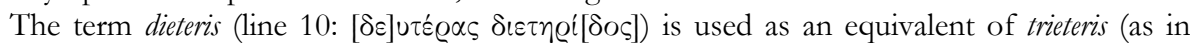
Aphrodisias). [JM]

263) K. Strobel - C. Gerber, "Feldforschungen in Tavium im Jahr 2000. Vorbericht", AST 19.2 (2001), p. 4-8 [BE 2003, 532; SEG LII 1244]: A dedication to Theos Hypsistos (RECAM II 418, 1st/2nd cent.) was rediscovered in Tavium. [AC]

264) R.S. STROUD, “Adolf Wilhelm and the Date of the Hekatompedon Decrees", in Attikai Epigraphai, p. 85-97 [BE 2005, 189]: After a brief discussion of the main dates suggested for the famous Hekatompedon decrees $\left(I G I^{3} \quad 4\right)$ and the problems associated with the restoration of the archon name in A 14f. and B 26f., S. makes a strong argument for the restoration of the name of the archon Philokrates (485/4, as already restored by A. Kirchhoff). [JM]

265) J.H.M. STRubBe, "Cultic Honours for Benefactors in the Cities of Asia Minor", in L. DE LigT - E.A. HemelrijK - W. Singor (eds.), Roman Rule and Civic Life: Local and Regional Perspectives, Amsterdam, 2004, p. 315-330 [BE 2006, 327]: S. gives an overview of 
possible cultic honours granted to benefactors who were citizens, thus excluding Hellenistic kings, Roman magistrates, generals, and the collective cult of euergetai. The most certain indications of the cult of an euergetes are the appointment of a priest, the offering of sacrifices, and the erection of a cult statue in a temple (e.g. the cult of Diodoros Pasparos at Pegramon). The earliest document to attest cultic honours for a benefactor is a decree for Lyson from the Letoon near Xanthos in Lykia (SEG XLVI 1721, 196 BC). Other citizens who were granted cultic honours include Anticharis in Kyaneai (L. RoBERT, Études anatoliennes, Paris, 1939, p. 399-405), Parasitas in Knidos (I.Knidos 606), Apollonides (?) in Keramos (I.Keramos 9), Diodoros Pasparos in Pergamon (IGR 4, 292-294), Gnaeus Pompeius Theophanes in Mytilene (IGR IV 55b), Gaius Iulius Artemidoros in Knidos (I.Knidos 59), Caius Iulius Epikrates and his father Caius Iulius Apollonios in Miletos (SEG XLIV 942), Euthydemos and Hybreas in Mylasa (OMS IV 44, 103; V 53), and Caius Iulius Xenon in Thyateira (TAM V.2, 1098). An inscription from Kyme dated between 2 BC and $14 \mathrm{AD}$ (I.Kyme 19) refers to the rejection of cultic honours by Lucius Vaccius Labeo and marks the last epigraphical evidence for cultic honours granted to benefactors. According to S., the cultic honours for these benefactors were motivated both by their activities in the gymnasion [cf. supra no 5] and by their interaction with the Roman authorities in times of crisis. [JM]

266) R.A. STUCKY - H.-P. MATHYS - R. WACHTER, " $\Psi \varepsilon i \lambda \omega \tau \dot{\eta} \varsigma$ (Psilotes). A New Greek Word from the Sanctuary of Eshmun at Sidon", Archaeology and History in the Lebanon 20 (2004), p. 75-82 [BE 2005, 521]: An interesting inscription found in 1968 in the sanctuary of Eshmun at Sidon (AD 104) documents the dedication made by six members of a guild designated as $\psi \varepsilon i \lambda \omega \tau \alpha i$ for the well-being of themselves and their families. The Greek $\psi \varepsilon i \lambda \omega \tau \eta \dot{n} s$ is a loan from the Semitic verb psl which means 'to cut stone, to sculpture'; the $\psi \varepsilon i \lambda \omega \tau \alpha i$ were a professional guild of stone masons and/or sculptors [who may have

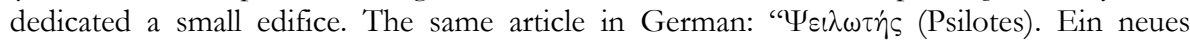
griechisches Wort aus dem Eschmun-Heiligtum in Sidon”, $A$ A (2005), p. 39-46]. [JM]

267) D. SumMA, 'Una dedica coregica inedita', ZPE 150 (2004), p. 147-148 [BE 2005, 206]. Ed. pr. of a choregic monument in Athens (second half of the 4th cent.), seen by J. Kirchner. The text gives the names of winners in the competition of comic choruses. [AC]

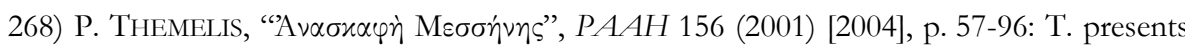
new finds from Messene. The Karneiastas Leon and six isooi dedicated a bronze statuette to (Apollon) Karneios (p. 70-79, early 3rd cent.); most of the dedicants are known from other sources. This is the first direct attestation of the cult of Apollon Karneios in Messene; an inscription that mentions a $\theta \varepsilon \tilde{\omega} \nu$ a $\gamma \eta \tau \dot{\eta} \varrho(E B G R$ 2001, 181) is connected with this cult. From the analogous rite in Sparta, one may infer that the Karneastes was a young man representing his tribe at the Karneia. T. assumes that the hieroi were men selected by lot among prominent Messenians and initiated in the mysteries of Andania (cf. IG V.1, 1390); the thirty bieroi represented the five Messenian tribes (six from each tribe). Their number in this text suggests that they were members of the same tribe. In this context, T. makes the important observation that the "55th year" that dates the lex sacra of the mysteries of Andania is the 55th year of the Actian era, the dating system most commonly used in Messenia, and not the 55 th year after the conquest of Greece (146 BC); consequently the lex sacra should be dated to AD 24 and not 92/9 BC. The reformer of the mysteries, Mnasistratos, may be identified with the Mnasistratos, son of Philoxenidas, known from an honorary inscription of AD 42 (SEG XXIII 208) [cf. supra no 62]. T. also points out that the correct form of the name is Andaniai (plural), not Andania. Other epigraphic finds include a dedication to an anonymous deity (p. 79, 2nd cent.), the dedication of the statue of a 
hypogymnasiarchos to Hermes and Herakles by the ephebes (p. 93, 2nd cent. BC), an honorary inscription for a victor at the Olympia and the Lykaia (p. 81, 2nd cent.), a posthumous honorary inscription set up by the polis in a funerary building for Dionysios,

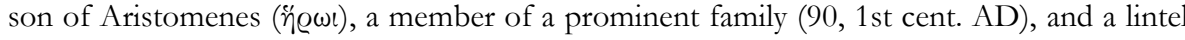

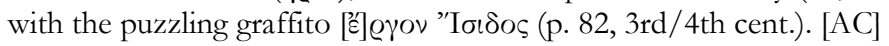

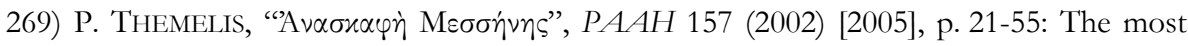
interesting among the new epigraphic finds from Messene is an honorary inscription for Antoninus Pius (p. 65) whose statue was dedicated to the gods by 'the Greeks', who thanked

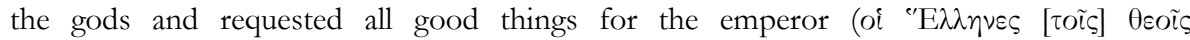

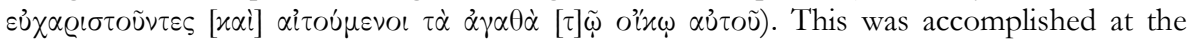
initiative and expense of Tib. Claudius Saithidas Kailianos II, high priest of the Greeks for

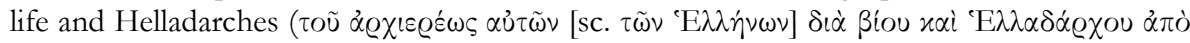

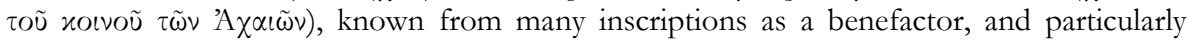
involved in the emperor cult. [The new finds from Messene (see also EBGR 2001, 108) make a new examination of the emperor cult in Achaia and of the office of the Helladarches necessary]. Among the other inscriptions we single out a dedication to Zeus Soter by a former agonothetes found in the sanctuary of Zeus Soter (44, 3rd cent.), a Latin dedication to Faustina (p. 45), an ephebic list dated with reference to the eponymous priest of Zeus Ithomatas (p. 50f., AD 177), and an epitaph with the unusual formula $x \alpha \lambda \dot{\eta} \psi v \times \dot{\eta}(x \alpha \lambda \dot{\eta}$

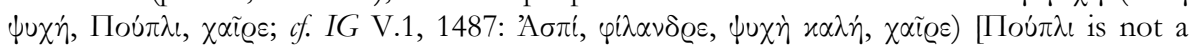
female name, but the vocative of Пoú $\pi \lambda_{\iota \varsigma}=$ Пoú $\left.\pi \lambda_{\iota \circ}\right] .[\mathrm{AC}]$

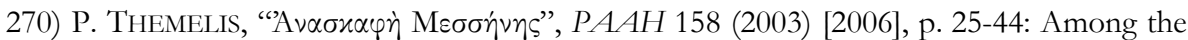
new inscriptions found in Messene in 2003 we single out a building inscription found near a Doric temple in the Agora; the famous sculptor Damophon and his sons dedicated the akroteria to Zeus, Theoi Pantes, and the Polis (2nd cent. BC; p. 35-37) [cf. V.C. PETRAKos,

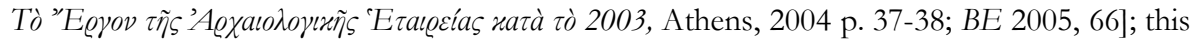
text shows that Damophon did not only work in the Asklepieion, but was also responsible for the bronze sculptures (central and side akroteria) of the temple of Zeus Soter. This temple cannot be identified with the Doric temple in the Agora, since the decrees that have been found near this temple were to be set up in the sanctuary of Messene. The temple of Zeus must have been somewhere nearby; the dedications of Damophon and the agonothetes Dioskouridas (infra) must have been brought to the temple of Messene from their original location in the neighbouring temple of Zeus Soter (p. 38). Another document found there concerns the leasing of land (undated; p. 38); the plots or areas are often named after deities (Artemitaion, Pythaeion, Hyakinthion). The other texts include a dedication to Aphrodite found near the theatre (undated; p. 28); the dedication by a woman of statues of her three grandchildren to Eleuthyia (undated, p. 42); a measure (sekoma) donated to Theoi Pantes and the city by a former agoranomos (AD 139; p. 34), and a posthumous honorary inscription for the Platonic philosopher Tib. Flavius [--]krates, who is called a heros (theatre, 2nd cent. AD; p. 27). [AC]

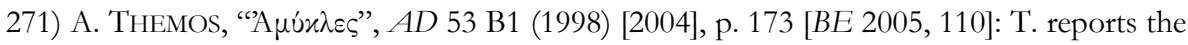
discovery of inscribed sherds of vases in a deposit in the sanctuary of Agamemnon and Kassandra (Amyklai, near Sparta, Archaic and Classical period). He gives the text of one of them, a dedication to Agamemnon [on this cult see EBGR 2003, 150]. [AC]

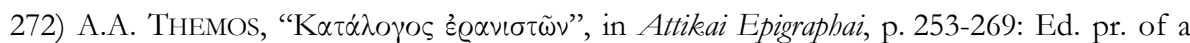
long list of 128 members of an eranos found accidentally at Ano Limni Zophra (Attica, now in the Piraeus Museum). The list was originally compiled in the 1st cent., but as one may infer from the letter forms, names were added until the late 1 st or 2 nd cent. AD. The 
document was first compiled by the hieropoios and kosmetes Apollonios under the archonship of Leukios the Younger from Rhamnous. The list is headed by the archieranistria Thaleia and Theodoros, the priest of Herakles, followed by the names of the eranistai. Male and female members are listed together, and besides the priest of Herakles only three names of eranistai are accompanied by a demotikon or a patronymikon. [JM]

273) C.M. THOMAs, “The 'Mountain Mother': The other Anatolian Goddess at Ephesos”, in Les cultes locaux, p. 249-262: The epigraphic evidence from the Ephesian Metroon, an openair sanctuary located on the north slope of the Panayır Dağ, shows that the cult of Meter dates from the early 4th cent. and continues into the Imperial period. None of the inscriptions addresses her under the name Kybele. The oldest inscription from the site refers to the cult place as a sanctuary of Zeus Patroos (I.Ephesos 104, 5th cent.). Another inscription found near the Metroon (also 5th cent.) refers to it as a joint sanctuary of Zeus Patroos and Apollon Patroos (I.Ephesos 101). T. suggests that the cult place was originally dedicated to Zeus and Apollon, while Meter arrived later and was installed in the same sanctuary. [JM]

274) P.J. Thonemann, "Polemo, Son of Polemo (Dio, 59.12.2)", EA 37 (2004), p. 144-149 [BE 2005, 421]: T. argues that L. Antonius Zeno, son of Polemon, an archiereus of Asia and eponymous priest from Laodikeia (e.g. SEG XXXVII 855; I.Laodikeia 53, $1^{\text {st }}$ cent. AD) is probably a descendant of king Polemon I of Pontus through the direct male line. [JM]

275) G. THÜR, "Gerichtliche Kontrolle des Asylanspruchs", in Asyl, p. 23-35: A review of the evidence concerning efforts to limit the right of convicts or prosecuted persons to find asylia in sanctuaries ( $c f$. EBGR 1996, 38bis) shows that a judicial procedure concerning the termination or limitation of asylia is attested only in connection with suppliant slaves ( $I G$ XII.6, 156 and 169; IG V.1, 1390). In Athens, the apagoge procedure permitted in certain cases the removal of suppliants from sanctuaries. T. argues that the inscription concerning the conviction of persons for murders committed in the sanctuary of Alea in Mantineia (IG V.2.262 = IPArk 8) and their expulsion for all time from this sanctuary did not aim at denying the convicted murderers the right of asylia in this sanctuary but at excluding them from the community ('Ausschluß der Verurteilten aus der Sakralgemeinschaft'). If Mantineia wanted to exclude the convicts from the 'Sakralgemeinschaft', it would have denied them access to every sanctuary in Mantineia, not only to this particular sanctuary; this is why I suspect that the verdict, confirmed through an oracle, aimed at terminating the asylia of the murderers. On the subject of supplication see F.S. NAIDEN, "Supplication and the Law", in E.M. HARRIS - L. RUBinsteIN (eds.), The Law and the Courts in Ancient Greece, London, 2004, p. 71-91; this volume will be summarized in SEG 2005]. [AC]

276) S.R. ToKHTAS'EV, “Zpigrafičeskie zametki”, in Anacharsis, p. 155-168 [BE 2006, 305; SEG LIII 786, 795bis, 808bis]: T. presents a series of epigraphical studies: 1) The priest who is mentioned in a dedication to Achilleus Pontarches (Olbia, 2nd cent. AD; IOSPE I ${ }^{2} 134$ ) was Mouxouvas Kúgou (not Mouxouvaxugos); these names belong to a group of Persian

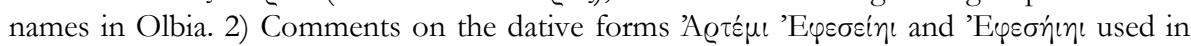
dedications to Artemis Ephesia in the area of Pantikapaion. 3) A new restoration of a dedication by a son of Leukon I to Aphrodite Ourania (Pantikapaion, c. 389-349; CIRB 7).

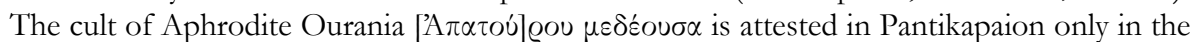
mid-2nd cent. (CIRB 75), but a graffito (A $\varphi \varrho O \delta[---])$ attests her cult already earlier (c. 520510 BC). 10) New edition of the inscriptions on a cylindrical gold capsule of an amulet (Tyritake, 3rd cent. AD; SEG XLV 1028(17)) with personal names and the word భux'. [AC]

277) R.S.O. Tomlin, "Sede in tuo loco: A Fourth Century Uterine Phylactery in Latin from Roman Britain", ZPE 115 (1997), p. 291-294: Ed. pr. of a Latin phylactery found at West 
Deeping (Imperial period). It invokes Iao, Sabao, Adonai and commands the womb to stay in its place (sede in tuo loco) [for similar spells see supra no 80]. [AC]

278) R.S.O. Tomlin, “A Roman Inscribed Tablet from Red Hill, Ratcliffe-on-Soar (Nottinghamshire)", Antiquaries Journal 84 (2004), p. 346-352: T. presents a new critical edition of a lead tablet from Red Hill (E.G. TURNER, "A Curse Tablet from Nottinghamshire", JRS 53 [1963], p. 122-124; probably 4th cent. AD) containing a Latin prayer for justice against a thief ("I make a note of two gaiters, an axe, a knife, a pair of gloves, whether woman or if man [--] two parts to the god"). The particular interest of the text lies in the use of the verb annoto, attested for the first time in a curse tablet (probably not in the meaning 'to cede'), and in the promise to the god of a share (duas partis deo) if the property is recovered [cf. infra no 280; on cession of property to gods see supra $\mathrm{n}^{\circ}$ 44]. [AC]

279) R.S.O. TOMLIN, “A Bilingual Roman Charm for Health and Victory”, ZPE 149 (2004), p. 259-266: Ed. pr. of a Roman gold amulet (Billingford). The amulet is a lamella cut from a thin gold sheet bearing ten lines written in Latin but in an interesting mixture of Greek and

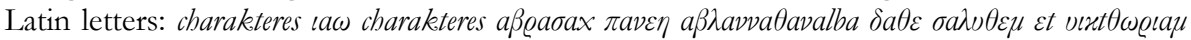
tib claum similem quem pepeperit herenia marcellina (i.e., Iao Abrasax PANEE ablan $n$ n $a$ thanalba date salutem et victstoriam Tib(erium) Clau(diu)m Similem quem peperit Heren(n)ia Marcellina; "Iao, Abrasax, ... give health and victory to Tiberius Claudius Similis whom Herennia Marcellina bore"). Interestingly, the most important part of the charm, the wish for wealth and victory, is written in Greek letters, with the scribe apparently transliterating a Latin formula, while the person's name is given in Latin. T. suggests that Tiberius Claudius Similis came from Lower Germany and most probably brought the amulet with him. [JM]

280) R.S.O. TOMLIN - M.W.C. Hassald, "Inscriptions", Britannia 34 (2003), p. 361-382: Ed. pr. of two lead curse tablets from Londinium. One of them (2, c. 3rd cent. AD) is a new example of a prayer for justice in which the defigens cedes to a divinity two thirds of lost or stolen property ([d]eae Dea[na]e dono capitularem et fas [c]iam minus parte tertia si quis hoc feci[t s]i p[u]er si [p]uella s[i] [s]er[vus] s[i liber] don[o eum] nec p[er] me [vi]v[ere] possit, "I give to the goddess Deana my headgear and band less one-third. If anyone has done this, I give him, and through me let him be unable to live") [cf. infra no 278]. The second text (3, c. 4th cent. $\mathrm{AD})$ is almost illegible, but its interesting feature is the fact that it has four holes that imply that it was nailed to something [for the significance of the display of curse tablets see EBGR 2003, 87]. [AC]

281) J. TREMEL, "Die Befragung des Orakels durch Athleten", Nikephoros 17 (2004), p. 111 118: T. discusses the (primarily literary) evidence for athletes who consulted oracles before their participation in athletic contests; this evidence includes two inscriptions. An epigram of unknown provenance (J. EBERT, Griechische Epigramme auf Sieger an gymnischen und hippischen Agonen, Berlin, 1972, $\mathrm{n}^{\circ}$ 30, 5th cent.?) from the Cod. Pal. refers to a victorious athlete from Crete who after winning the boxing contest at the Isthmia dedicated an unspecified offering to Apollon (Delphi?). T. accepts the suggestion made by J. Ebert that the reason for this dedication could have been a favourable oracular response regarding the chances of the athlete during the forthcoming athletic event. [Nevertheless, nothing in the wording of the

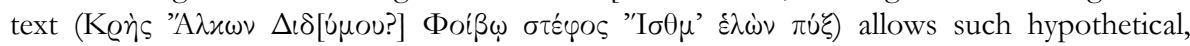
though interesting, interpretation]. Much more clear is the case of the epigram referring to the oracular response given to Apphion from Alexandria by Apollon in Didyma. The bull tamer Apphion, who apparently danced on the bull's bare back, asked Apollon Didymaios about his chances of victory in a forthcoming event. Both his question and the favourable divine answer were presented on stone in the Sarapeum in the south market of Miletos (SEG IV 425; SGO 01/20/02, 2nd cent. AD). [JM] 
282) J. Tremel, Magica agonistica. Fluchtafeln im antiken Sport, Hildesheim, 2004 Nikephoros Beih. 10) [BE 2005, 88]: In this study T. demonstrates that in Graeco-Roman antiquity almost every kind of athletic contest could become the object of magic. The existing evidence shows that runners, wrestlers, charioteers, and even animal fighters were potential victims of binding spells. Defixiones were not used in athletic contexts in which rivalry was not important. There is also little evidence for the use of defixiones in connection with gladiatorial combats. The majority of the 'agonistic curses' concern the Roman circus. The pre-eminent position of circus spectacles in Roman life explains the fact that most of the 'agonistic defixiones' are directed against charioteers, their horses, or both. 'Agonistic curses' can be found from the 6 th cent. $\mathrm{BC}$ to the 6 th cent. $\mathrm{AD}$, but the vast majority seems to date to the late Imperial period. T. presents 100 examples of already published agonistic curses in a very useful catalogue with bibliographical references, original text, and German translation [for $\mathrm{n}^{\circ} 11$ (a very long defixio found in the hippodrome of Antioch) see now EBGR 2003, 72]. [JM]

283) C. TRÜMPY, "Die Thesmophoria, Brimo, Deo und das Anaktoron: Beobachtungen zur Vorgeschichte des Demeterkultes", Kernos 17 (2004), p. 13-42: In this important study, T. approaches from the linguistic point of view the meaning of Thesmophoria ('the carrying/ bringing of thesmoi, not in the sense of norms or laws but in the sense of sacred objects that are to be deposited). The theonyms of Demeter/Da-mater and Poseidon/Posei-da-on are composita consisting of the Indoeuropean words mater and potis and the prehellenic word $d a$. T. rejects with linguistic arguments the interpretation of ma-ka o-po-re-i ko-wa in the Linear-B tablets of Thebes as the equivalent of Ma Ge, Zeus Opores, and Kore ( $c f$. IG VII 2452: $\Gamma \tilde{\alpha}$

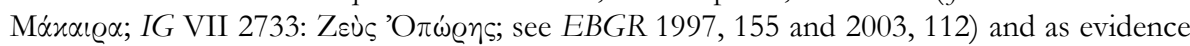
for the cult of a divine triad. If ma-ka was a goddess, she had nothing to do with Demeter, whose names in the Bronze Age were Dao and Damater. The divine epiklesis potnia meter may originate in the $2 \mathrm{nd}$ millennium $\mathrm{BC}$; consequently, the ritual announcement of the

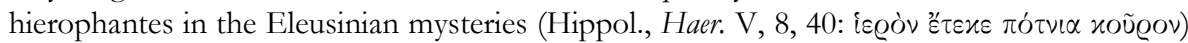
seems to be a poetic formula inherited from the Mycenaean period, as is the designation anaktoron in the cult of Demeter in Eleusis a relic of the Mycenaean period and an indication that the wanax was an object of worship. [AC]

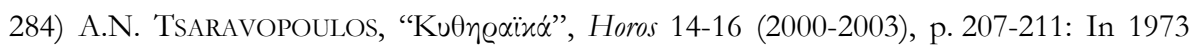
three oinochoai were found during cleaning work in the well of the monastery of St. Theodori in Kythera. One of the vases has a graffito (5th cent.) showing that it was dedicated by Herakleidas to Asklepios (Ai $\gamma \lambda \alpha \pi i \omega \iota)$. [JM]

285) I. Tsarov, Annuaire du musée historique de Veliko Târnovo 14 (1999) 78-82 [SEG LIII 724725; non vidimus; see N. SHARANKOV, AE 2003, 1565]: Ed. pr. of two reliefs representing the Thracian Rider dedicated to Heros Souregethes (Veliko Tarnovo, area of Nikopolis ad Istrum, early 3rd cent. AD). One of them was dedicated to Heros Souregethes (p. 80f.), the

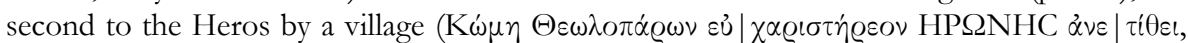
p. 83-85) [both mentioned by M. OPPERMANN, Der Thrakische Reiter, Langenweißbach, 2006, p. 336 Kat. 439 and 353 Kat. 968]. [AC]

286) D. Tsouklidou, "A New White-Ground Panathenaic Amphora", $M D A I(A) 118$ (2003), p. 383-395: Ed. pr. of a white Panathenaic amphora found near the Odeion of Herodes Atticus in Athens (c. 150-140 BC). The representation (Athena on the obverse, kitharist or auletes and Nike on the reverse) and the inscription on the reverse ( $\tau \tilde{\omega} v$

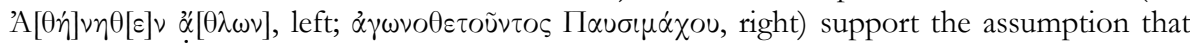
the prize given in the dramatic performances at the Panathenaia were white Panathenaic amphoras; these competitions were introduced in the Hellenistic period (cf. SEG XLI 115 
III 39-43). Pausimachos may be Pausimachos, son of Demokles, the victor in a chariot race in the Panathenaia of 170 BC (SEG XLI 115 I 39-40) and epimeletes in Delos in c. 150 BC (I.Delos 1618 line 2) [the father of Eumachos in IG II² 2452 line 28]. [AC]

287) R.A. TyвOUT, "Naar een andere wereld. Verkenningen van het Griekse grafepigram op steen", Lampas 36 (2003), p. 329-377 (English summary): Using a large number of grave epigrams, T. summarizes the evidence they provide for a large variety of ideas about death and the afterlife. The fact that the motifs were often taken from anthologies may explain why contradictory ideas appear in one and the same epigram. [AC]

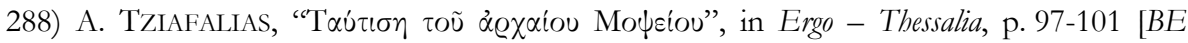
2004, 221; SEG LIII 559): Ed. pr. of a fragmentary inscription found at Gyrtoni in Thessaly

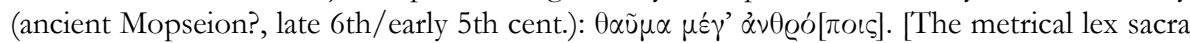
of the sanctuary of Meter in Phaistos (I.Cret. I, xxiii, 3; supra $\mathrm{n}^{\circ} 23$, 2nd cent.) begins with the

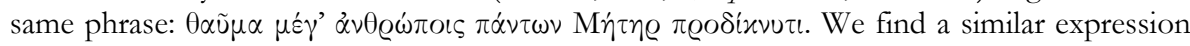
in another revelation of divine power, the appearance of Asklepios' sacred snake (I.Cret. I,

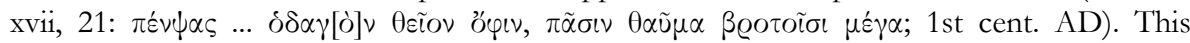
expression may have been inspired by the Delphic oracle concerning Asklepios (Paus. II, 26,

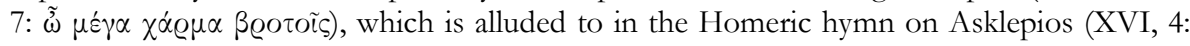
$\left.\chi \chi^{\alpha} \varrho \mu \alpha \mu \dot{\varepsilon}^{\prime} \dot{\alpha} \nu \theta \varrho \dot{\omega} \pi \circ \iota \sigma \iota\right)$, the famous paian for Asklepios known from Athens, Dion, Erythrai, and Ptolemais (W.D. Furley - J.M. BrEMER, Greek Hymns. II. Greek Texts and

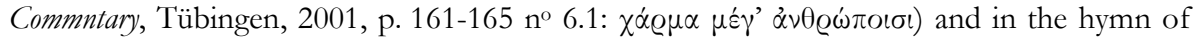

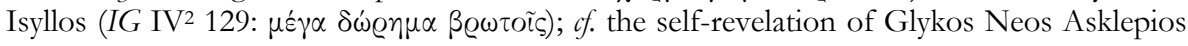

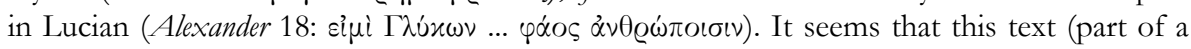
dedicatory epigram?, an acclamation?) records an epiphany, perhaps of Asklepios, whose cult probably originated in Thessaly (see now J. RIETHMÜLLER, Asklepios. Heiligtümer und Kulte I, Heidelberg, 2005, p. 37-39, 91-106)]. [AC]

289) Y. Ustinova, "Truth Lies at the Bottom of a Cave: Apollo Pholeuterios, the Pholarchs of the Eleats, and Subterranean Oracles", PP 59 (2004), p. 25-44: A marble stele (3rd cent.) found in Histria bears a dedication to Apollon Pholeuterios (I.Histriae 105). The epiclesis $\varphi \omega \lambda \varepsilon v \tau \eta \dot{n} \varrho \iota \varsigma$ is known solely from this inscription and its meaning remains obscure. $\mathrm{U}$. offers an intriguing interpretation of $\varphi \omega \lambda \varepsilon v \tau \eta \dot{n} \varrho \iota \varsigma$ in connection with the basic meaning of the verb $\varphi \omega \lambda \varepsilon \dot{\omega} \omega$ ('to live or hide in a cave or a hole'). According to U., the Histrian Apollon Pholeuterios could have been a divinity worshiped in a subterranean cavity, which could have served as an oracle. The veneration of Apollon in caves was not widespread, but nevertheless known from Athens, Aulai, and Themisonion, while the use of caves in the context of oracular activities is known from the entire Greek world. U. also discusses the term $\varphi \omega \dot{\lambda} \alpha \varrho \chi 0 \varsigma$ used to designate the head of a medical association in Elea devoted to the cult of Apollon Oulios (SEG XXXIX 1078) [infra $\mathrm{n}^{\circ}$ 293]. U. suggests that the members of the association descended into a cave ( $\varphi \omega \lambda \varepsilon o ́ \varsigma)$ in the course of ceremonies for Apollon Oulios, in order to receive divine wisdom (perhaps adopting Pythagorean traditions). Despite the linguistic connection between the Histrian epiclesis $\varphi \omega \lambda \varepsilon v \tau \dot{\eta} \varrho \iota \varsigma$ and the Elean term $\varphi \omega \dot{\lambda} \alpha \varrho \chi \circ \varsigma, \mathrm{U}$. demonstrates that there was no connection between the Histrian cult and the Elean medical association, as suggested by D. Pippidi. [JM]

290) M. J. VACHTINA, 'Archaic Buildings of Porthmion', in The Cauldron of Ariantas, p. 37-54 [SEG LIII 802]: In a report on the Archaic phase of Porthmion (North Shore of the Black Sea), V. presents a base fragment of an Attic black-glazed bowl dedicated to Parthenos, found in a layer of destruction (43-45, early 5th cent.; cf. SEG XLIII 514). [AC] 
291) R. VAN BREMEN, "Leon Son of Chrysaor and the Religious Identity of Stratonikeia in Caria", in The Greco-Roman East, p. 207-244 [BE 2005, 437]: Three inscriptions found at Panamara honour Leon, son of Chrysaor of Stratonikeia, for his role as priest of Zeus Karios. The decrees (2nd cent.) were issued by the koinon of the Panamareis (I.Stratonikeia 7), the city of the Kallipolitai (SEG XLV 1556), and the koinon of the Laodikeis (SEG XLV 1557) [the latter texts are republished in HTC 84 and 89; see now also R. VAN BREMEN, "Laodikeia in Karia", Chiron 34 (2004), p. 367-398]. The decree of the Panamareis emphasizes Leon's efforts to promote the sanctuary of Zeus Karios and the revival of the cult. The other two decrees refer to the arbitration of Leon "between those who disagreed

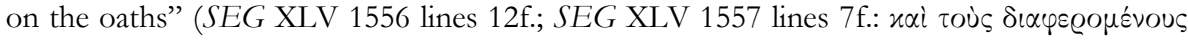

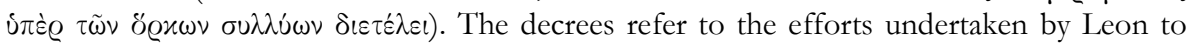
create a cult community with the sanctuary of Zeus Karios as its religious centre. The swearing of oaths is expected in this context. In a politically complex and dangerous situation, Leon apparently tried "without sparing danger or cost or suffering" (I.Stratonikeia 7 lines 10-11) to persuade among other communities also an autonomous polis on the coast (Kallipolis) and one under Rhodian control (Laodikeia) to participate in a common cult (Zeus Karios/Panamaros) under the control of Stratonikeia. In this respect, the Stratonikeis attempted a "gentle" territorial expansion trying at the same time to gain access to the sea through a religious procedure. This is why Leon's ethnic Stratonikeus is present in the decree of Kallipolis but ommited in that of Laodikeia: the koinon of the Laodikeis tried to avoid the name of a city hated by the Rhodians. [JM]

292) E. VArinlioglu, "Die Inschriften von Keramos", in V. RugGIERI (ed.), Il golfo di Keramos: dal tardo-antico al medioevo bizantino, Soveria Mannelli, 2003, p. 395-411 [SEG LIII 1202, 1209-1212]: Ed. pr. of inscriptions from Keramos. The most interesting text commemorates the performance of a prayer (for the emperor?) [to the emperor?] by the

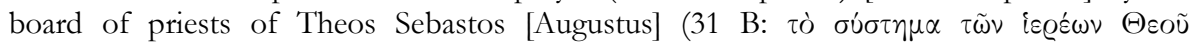
$\left[\sum \varepsilon \beta \alpha \sigma\right] \tau O \tilde{u} \lambda \iota \tau \dot{\eta} \nu$ ध่ $\pi \circ$ in $[\sigma \varepsilon]$; c. 150-200 AD) [prayers to the emperor are directly mentioned

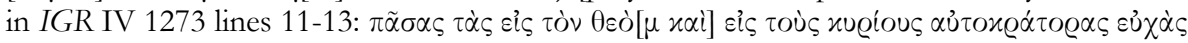
nai $\theta v \sigma i \alpha s]$. The other texts include a posthumous honorary inscription for a man, whose statue was dedicated to the gods by his parents and brothers (cf. I.Keramos 5; 5A, Hellenistic); the dedication of a sundial to the Demos and the Theoi Keramietai Megaloi (8A, Hellenistic); the dedication of an altar in accordance with decrees (31A, ca. 150-200 AD); dedications to Septimius Severus and his family (33A) and to an anonymous emperor (83A). [AC]

293) L. VECCHIO, Le iscrizioni greche di Velia, Vienna, 2003: Corpus of 79 inscriptions of Elea/ Veleia (if no other date is given, the texts date to the Classical period). V. gives a short introduction to the cults of Elea (p. 29-34) [cf. EBGR 2000, 139]. Boundary stones of sanctuaries or sacred property (1-12), building inscriptions (13?, 14), a dedication (17), and altars $(14,18)$ attest the cults of Athena [Helle]nie and Zeus [Helle]nios (1), Athena Polias (17, Imperial period) Hera Thelxine (9), Hera (10-12), Hestia (18, Hellenistic), Persephone and Hades (15, Hellenistic), Poseidon Asphaleios (7), Poseidon (8), Zeus Orios (sc. Ourios; 2), Zeus Al[astor?] kai Orios (5), Zeus Hypatos Athe[naios?] (6), (Zeus?) Exakesterios (13), Zeus Polieus (14, Hellenistic), Olympios Kairos (3), and Pompaios (4). A stone (argos lithos)

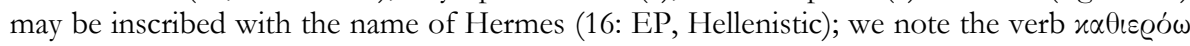

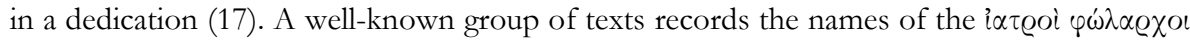
(22-24, 1st cent. AD), the leaders of the Eleatic school of medicine which was organised as a cult community, possibly connected with Apollon Oulios (all these leaders have the name or signum Oulis) [cf. supra no 289]. [AC] 
294) H.S. Versnel, "Writing Mortals and Reading Gods. Appeal to the Gods as a Strategy in Social Control", in D. COHEN (ed.), Demokratie, Recht und soziale Kontrolle im klassischen Athen, Munich, 2002, p. 37-76: Continuing his studies on the social aspects of curses and concepts of divine justice, V. collects and discusses representative examples of 'prayers for justice' (primarily from Athens and Knidos, but also from Asia Minor, Egypt, and western Europe) as well as of confession inscriptions, whose background in many cases is similar to that of the 'prayers for justice' (e.g., BIWK 69) [cf. supra nos 44-45 and 99]. In his analysis of numerous texts and in particular of the persuasion strategies applied by the victims of wrongdoing in order to provoke divine punishment, V. stresses the need to avoid generalisations in the study of appeals to divine justice. Some 'prayers for justice' were publicly accessible and meant to inform the culprit that he was pursued by the gods, but this should not be taken for granted for all relevant texts (e.g., for the Knidian tablets); the content of curses deposited in temples was probably known to the priests. V. identifies two different strategies of social control connected with this category of texts: people appealed to the gods for help against an opponent; and they informed the opponent that the gods have been called in for assistance. While these strategies worked in times and places in which a strong religious climate prevailed and secular institutions were not in a position to provide effective assistance, they did not play a significant role in Classical Athens. [Other relevant articles in the same volume will be presented in EBGR 2005]. [AC]

295) A. VILLING, "For Whom the Bell Tolls in Ancient Greece? Archaic and Classical Greek Bells at Sparta and Beyond", ABSA 97 (2002), p. 223-295 [BE 2005, 100]: V. gives an excellent overview of the various functions (military, ritual, practical, dedicatory) of bells in ancient Greece. 136 bronze and clay bells have been found as dedications in the sanctuary of Athena Chalkioikos in Sparta, three of them inscribed and explicitly designated as dedications to Athena ( $\mathrm{Br} 1,8,10,12$ and 14, 5th-4th cent.); the dedication were made by both men and women. The exact significance of the dedication of bells in this particualar sanctuary cannot be determined, given the variety of possible functions (apotropaic, prophylactic, purificatory, magical). [AC]

296) J.G. Vinogradov - A.S. Rusjaeva, "Graffiti iz svjatiliša Apollona na zapadnom temenose Ol'vii", in Anacharsis, p. 134-142 [SEG LIII 788]: V.-R. present 23 graffiti on vases dedicated to Apollon, found in the western Temenos of Olbia (c. 550-400). With a few exceptions (1, 4-5, 9, 12: cf. IGDOP 56-57, 59, 83, 99) the texts are new. We summarize the

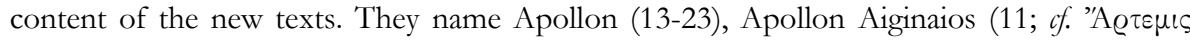
Airivía in Paus. III, 14, 2), Apollon Bores (8, 10), and (Apollon) Ietros (2-3, 6-7). In one case the dedication is specified as $\mu \varepsilon^{\prime} \lambda \iota \pi \alpha \tau \varrho[\omega \dot{\omega} \iota v ?]$ (8) [the reading cannot be checked; could it be

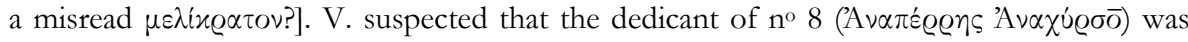
the son of the legendary sage Anacharsis. [AC]

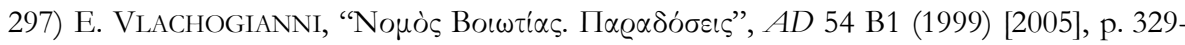
331 [BE 2006, 198, 206; SEG LIII 456 and 475]: Ed. pr. of an honorary inscription on a

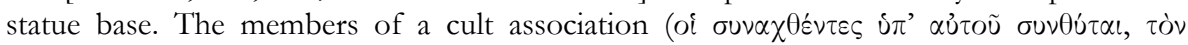

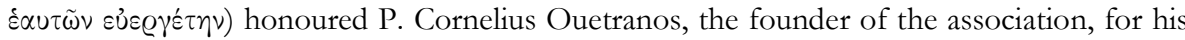

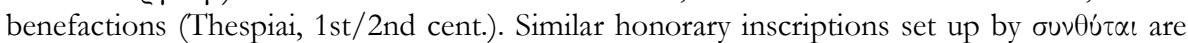
known from Boiotia (P. RoEsCH, Études béotiennes, Paris, 1982, p. 120-128). V. also mentions a fragmentary dedication from Hyettos [one recognizes the verb [avํ] $\theta \eta x[\varepsilon]$ and perhaps

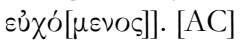

298) G. VотTÉro, "Boeotica epigrammata”, in L’épigramme, p. 69-122: V. compiles a collection of Boiotian epigrams, presenting their text, translation, and comments on language and metre. This useful collection includes a series of dedicatory epigrams addressed to Apollon 
in Thebes $(1=L S A G$ p. 94 no. 1) and in Delphi (2, 5, and 6; F.Delphes III.3, 268, 271 and V.3, 269; cf. no 27, commemorating the battle at Plataia); Apollon Ptoios in Akraiphia (4 = CEG 333; 7 = CEG 334; 10 and $15=$ CEG 336; 36 = SEG LIII 454); Apollon Platytoxos (18 = CEG 331); Dionysos (21 = IG VII 1794); the Muses (34 = IG VII 4240; $41=$ IG VII 1818 , by a victorious auletes; $43=$ IG VII 1796-1805); Mnemosyne and the Muses in Thespiai (44 = SEG LIII 476); Zeus (22 = IG VII 2462; commemorating the victory at Leuktra); the gods ( $8=$ CEG 327; Thebes, by a potter; $24=I G$ VII 2537, the statue of a young warrior dedicated by his father); [this is not an 'épigramme funéraire' in a narrow sense; the reference to the gymnasion in line 2 suggests that the statue was dedicated in the gymnasion ( $f$. SGO II 08/01/40 in Kyzikos and supra nos 26 and 109)]; and to anonymous gods $(17=I G$ VII 4249; $28=A P$ 6.344; an ex-voto of the Thespians who participated in the campaign of Alexander). Victories in contests are mentioned in the dedicatory epigram of a herald, who won a victory in a contest in honour of Zeus (Basileia?; Thebes; $38=I G$ VII 530), and in the funerary epigram for a boxer who won victories at the Nemea and the Basileia (39 = IG VII 4247). The funerary monument for a warrior who was killed in a battle (37 = GV 1603; 3rd cent.) was probably erected near the altar of Zeus Soter in Akraiphia (cf. line 6), where the military catalogue was exhibited; [the text does nor refer to a funerary, but to a commemorative monument erected by the man's wife and daughter]. The most

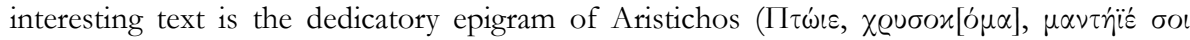

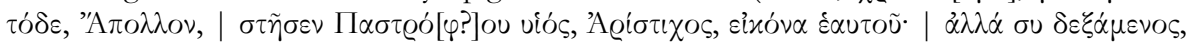

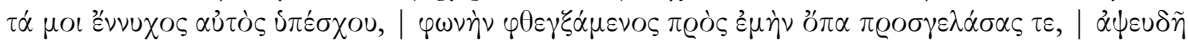

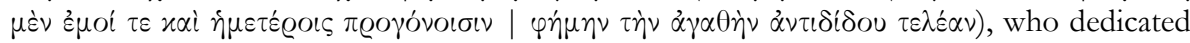
his own statue to Apollon Ptoios in Akraiphia (36, 3rd cent.), after the god had appeared in his dream and (according to the translation of P. GuILlon, Les trépieds du Ptoion, Paris, 1943, p. 109-115) had promised him and his descendans prophetic abilities ("accorde-moi en échange, véridique pour moi comme pour mes ancêtres, la bonne parole prophétique qui s'accomplit"). [AC]

299) R.S. Wagman, "Pan Dendrophorus?”, PP 57 (2002) 357-361: W. discusses the representation of Pan on a votive relief dedicated by phrouroi in Epidauros (IG IV 2305 ). The god is represented holding an object (tree, branch, club?) and standing in front of a cave (?). This unusual motif suggests that the relief refers to an Epidaurian cultic particularity, either to a specific cult place of Pan or, more probably, to the perception of the god as a guard holding a club. This would explain why this relief was dedicated by those guarding the territory. $[\mathrm{AC}]$

300) J. WAgneR - G. PetZL, "Relief- und Inschriftenfragmente des kommagenischen Herrscherkultes aus Ancoz", in Religionsgeschichte Kleinasiens, p. 85-96: Fragments of a Kommagenean basalt relief found as early as in 1958 in the village of Ancoz (today lost) attested the existence of a temenos dedicated to the Kommagenean ruler cult for Antiochos I. In 1979/80 further small fragments of reliefs and inscriptions were found during a survey directed by S. ALP, so that today 19 fragments are known from this site. W.-P. admirably put the jigsaw-puzzle together, suggesting that originally at least four or five basalt stelai and one big limestone stele (most probably depicting the king together with Apollon or ApollonMithras-Helios-Hermes) stood in the temenos of Ancoz. The very fragmentary inscribed blocks certainly belonged to inscriptions comparable to those found in the large hierothesia of Nemrud Dağı and Arsameia-on-the-Nymphaios. [JM]

301) R. WeIR, Roman Delphi and its Pythian Games, Oxford, 2004 [BE 2005, 239]: Making ample use of the rich epigraphic material and the literary sources W. draws an intriguing picture of the sanctuary of Delphi and its panhellenic games from the early 1 st to the mid 
3rd cent. AD, discussing in more detail the period between Nero and Antoninus Pius. After an introductory chapter on Delphi and the Pythian games during the 6th cent. (p. 10-48), W. stresses that the central position of Delphi in the definition of Greek cultural identity did not experience severe changes in the Imperial period. The second chapter (p. 49-76) is dedicated to the administration of the sanctuary (epimeletai, agonothetai). Based on a detailed collection of the epigraphic material, W. presents a catalogue of the fourteen known Pythian agonothetai for the Roman period. The following chapter deals with the architectural setting of the sanctuary (p. 77-107) based on the descriptions by Plutarch and Pausanias, the information delivered by the archaeological research at the site, and the inscriptions reffering to contructions, restaurations or damages at the sanctuary (e.g., FD III.4, 269, 331) [one minor problem is the absolute absence of plans and photos]. Chapter four (p. 108-139) discusses inter alia the inscriptions that attest the presence of philosophers and sophists (e.g., FD III.1, 199, 203, 204; III.2, 98, 116; III.3, 244; III.4, 83, 91, 94, 115, 474), as well as the victors at Roman Delphi (see table 4.2 for a detailed list of Delphic victors with the relevant epigraphic references). W. discusses briefly the very interesting inscription referring to the three victorious daughters of Hermesianax (FD III.1, 534) suggesting that this inscription should be seen as an attestation for mixed stadion competitions [on this rather problematic issue and on this text see the recent bibliography summarised in EBGR 2002, 69 and 2003, 42; the expression $\pi \varrho \dot{\omega} \tau \eta$ ' $\pi^{\prime}$ ' $\alpha \tilde{i} \tilde{\omega} \nu o \varsigma$ in the text referring to Hedea should be translated as "first ever" and not as "first of the century"]. The next chapter (p. 140-175) is dedicated to the benefactorial activity of Roman emperors at Delphi with a more detailed study of the relationship of Domitian, Hadrian, and Antoninus Pius to the Delphic sanctuary. The final chapter (p. 176-211) presents a very useful discussion of new Pythian games founded in Rome and in cities in the Roman East between the reigns of Commodus and Gallienus. In numerous tables W. summarizes the relevant epigraphic evidence from thirty cities and presents detailed tables on the numismatic evidence of the 3rd cent. AD for Pythian games in cities in Mainland Greece and Asia Minor listing only coins with the explicit use of the

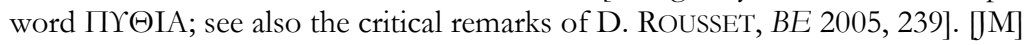

302) D. Whitehouse, Roman Glass in the Corning Museum of Glass. Volume Three, New York / Manchester, 2003 [SEG LIII 2125]: Inscribed glass objects in the collection of the Corning Museum of Glass include three pendants with the acclamation عi் $\theta \varepsilon o ́ \varsigma$ and a representation of a lion (891-893, unknown provenance, c. 350-450 AD). [AC]

303) M. WÖRRLE, "Ermandyberis von Limyra, ein prominenter Bürger aus der Chora", in F. KOLB (ed.), Chora und Polis, Munich, 2004, p. 291-302: Ed. pr. of an honorary inscription written on the base of a bronze statue of Ermandyberis posthumously dedicated by Pteunase to the gods in Limyra (Limyra, c. AD 100). Ermandyberis had served as a priest of the emperors. During his term as prytanis, Limyra organised the $\varepsilon \theta v \iota \dot{\eta} \pi \alpha v \eta \dot{\gamma} \gamma$ Qıs, i.e., the assembly and the agon of the Lykian Koinon. [AC]

304) M. WÖRRLE, "Maroneia im Umbruch. Von der hellenistischen zur kaiserzeitlichen Polis", Chiron 34 (2004), p. 149-167 [BE 2005, 382; SEG LIII 659]: W. discusses the fragmentary decrees of Maroneia concerning the organisation of future embassies to Rome to protect the city's privileges [EBGR 2003, 28]. W. comments on the unusual procedure for the selection of the envoys, who were not elected from among the citizens of Maroneia but simply declared their willingness to serve as envoys and took the relevant oath. According to W., this unusual mode of appointment is the reason for the special divine protection achieved through double oaths. [JM]

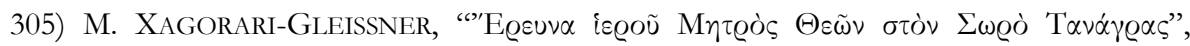
PAAH 157 (2002) [2005], p. 65-77: A sanctuary of Meter Theon, originally excavated in 
1874 (cf. IG VII 560-562), was located again at Soros, near Tanagra, and excavated. The finds show that the sanctuary was founded in the 5th cent.; the cult continued until the Roman Imperial period at the earliest (cf. IG VII 560) [which should be dated to the Imperial period and not to the 2 nd cent. $\mathrm{BC}$. [AC]

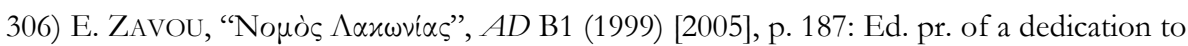

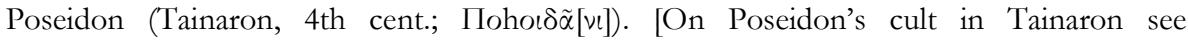

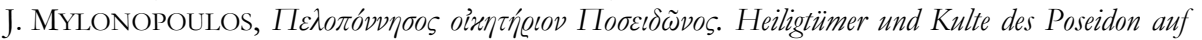
der Peloponnes, Liège, 2003 (Kernos, suppl. 13), p. 229-240]. [AC]

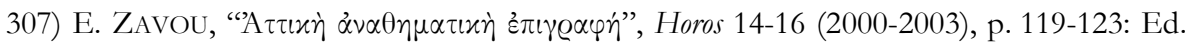
pr. of a dedicatory inscription on a statue base (Athens, 2nd cent.) found reused in the Late Roman fortification wall north of Hadrian's library. The statue of Euktimenos, son of Theomedes of Anagyrous, was dedicated by his mother and sister, after he had served as phylarchos. Z. identifies the father of the honoured person with the hippeus Theomedes Anagyrasios known from curse tablets found in Kerameikos and in the Athenian Agora. [JM]

308) D.V. Zhuravlev, "Terra Sigillata and Red Slip Pottery in the North Pontic Region (a Short Bibliographical Survey”, ACSS 8.3/4 (2002), p. 239-309 [SEG LII 731]: Z. compiled a catalogue of stamped inscriptions on Eastern sigillata B found on the North Shore of the Black Sea (p. 245); they include the names of gods (Isis and Sarapis). [AC]

309) R. ZIEGLER, "Der Burgberg von Anazarbos in Kilikien und der Kult des Elagabal in den Jahren 218bis 222 n. Chr.”, Chiron 34 (2004), p. 59-85: Coins minted in Anazarbos during the reign of Helagabalus very often depict Zarbos, the holy mountain (the acropolis) of the city. After a thorough study mainly of the relevant numismatic material, but also making ample use of the existing epigraphic sources, Z. suggests that such depictions are strong evidence for the introduction of the Syrian cult of Helagabalus in Anazarbos and his amalgamation with the local mountain god Zeus Olybreus. Z. assumes an analogous amalgamation of the Syrian Aphrodite of Emesa and the local (Aphrodite) Kassalitis. With its coinage, Anazarbos was able to postulate an affinity between its own holy mountain Zarbos and the holy mountain of Emesa, where Helagabalus' main sanctuary existed, so creating a tight connection with the new emperor. [JM]

\author{
Angelos CHANIOTIS \\ All Souls College \\ OXFORD OX1 4AL \\ angelos.chaniotis@classics.ox.ac.uk
}

\author{
Joannis MYLONOPOULOS \\ Theorie und Geschichte antiker Religionen \\ Universität Erfurt \\ Nordhäuser Straße 63 \\ D - 99089 ERFURT \\ joannis.mylonopoulos@uni-erfurt.de
}

